\title{
Examination of Legacy Metallic Fuel Pins (U-10Zr) Tested in FFTF
}

W. J. Carmack, D. L. Porter,

D. G. Cummings, H. J. M. Chichester, S.L. Hayes - INL

D. W. Wootan - PNNL

April 2013

Rev. 1 May 2020

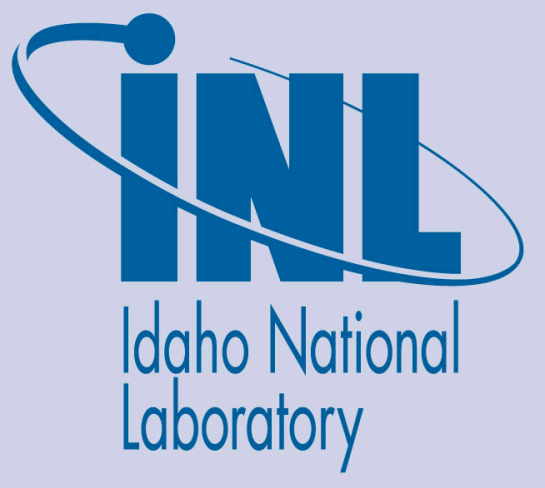




\section{DISCLAIMER}

This information was prepared as an account of work sponsored by an agency of the U.S. Government. Neither the U.S. Government nor any agency thereof, nor any of their employees, makes any warranty, expressed or implied, or assumes any legal liability or responsibility for the accuracy, completeness, or usefulness, of any information, apparatus, product, or process disclosed, or represents that its use would not infringe privately owned rights. References herein to any specific commercial product, process, or service by trade name, trade mark, manufacturer, or otherwise, does not necessarily constitute or imply its endorsement, recommendation, or favoring by the U.S. Government or any agency thereof. The views and opinions of authors expressed herein do not necessarily state or reflect those of the U.S. Government or any agency theof. 
INL/EXT-20-28987-R.1

\title{
Examination of Legacy Metallic Fuel Pins (U-10Zr) Tested in FFTF
}

\author{
W. J. Carmack, D. L. Porter, \\ D. G. Cummings, H. J. M. Chichester, \\ S.L. Hayes - INL \\ D. W. Wootan* - PNNL \\ April 2013 \\ Rev.1 - May 2020 \\ Idaho National Laboratory \\ Idaho Falls, Idaho 83415 \\ *Pacific Northwest National Laboratory \\ http://www.inl.gov \\ Prepared for the \\ U.S. Department of Energy \\ National Nuclear Security Administration \\ Under DOE Idaho Operations Office \\ Contract DE-AC07-05ID14517
}


INTENTIONALLY BLANK 


\section{SUMMARY}

The MFF series of metallic fuel (U-10wt\%Zr) tests performed in the Fast Fuel Test Facility (FFTF) were the beginning tests to qualify the fuel as a driver fuel for FFTF. They all performed very well, to relatively high burnup and with no pin breaches. Tests MFF-3 and MFF-5 were chosen to be destructively examined because they were run at high peak cladding temperatures, 643 and $649^{\circ} \mathrm{C}$ respectively, and to modest to high burnup (138 and $101 \mathrm{MWd} / \mathrm{kgM}$ respectively). They were the only sodium fast reactor (SFR) metallic tests, with long $(91.4 \mathrm{~cm})$ fuel columns and clad in HT9, to be operated at these high temperatures.

Extensive operating condition reconstruction was performed to accompany the examination, providing detailed operating conditions axially along the pins. In addition, detailed ORIGEN calculations provided fuel burnup along the pin length. These calculations and detailed cross-section metallography allowed a PhD dissertation to be performed where the fuel/cladding chemical interaction (FCCI) was modeled using Fickian and Soret Effect driven diffusion of rare earth fission products to the cladding surface and interact with the cladding.

The examination of the MFF-3 and MFF-5 pins included neutron radiography, axial profilometry including pin bow and length measurements, precision gamma scanning, plenum gas puncturing to measure fission gas release, detailed chemical/isotopic analyses of fuel samples to confirm burnup calculations, and metallography of pin cross-sections, including micro-hardness measurements of fuel and cladding.

The exams produced several interesting findings:

1. The axial fuel growth was very small, only 1.7 and 3.6\% for MFF-3 and -5 , respectively. Compare those values to the earlier FFTF test where U-10Zr fuel swelled axially $\sim 7 \%$.

Comparing design and operating conditions the high operating temperature of the MFF-3 and -5 tests are suspected as the potential cause. This is an important finding for prediction of future SFR fuel pin designs.

2. The axial profilometry of the more highly dosed MFF-3 pin $\left(19 \times 10^{22} \mathrm{n} / \mathrm{cm}^{2}, \mathrm{E}>0.1 \mathrm{MeV}\right)$ showed a pronounced double peak, one at the top of the fuel column and the other a little below peak flux location on the fuel column. MOX pins have previously shown this behavior with HT9 cladding. It may be due to a peaking in thermal creep at the top due to high cladding temperature and some wall thinning due to FCCI, and a peaking of the irradiation creep further down the fuel column due to high neutron exposure. Fuel pin length measurements indicated there may also be cladding swelling, but there was too much apparent growth in the MFF-5 pins to be accounted for with the small diameter increases. Cladding density would be needed to confirm.

3. The calculated and measured fuel burnups were very consistent.

4. The fission gas release value was low (61\%) for MFF-3 compared with other tests results, including MFF-5 (79\%), although only one pin from each test was measured.

5. Metallography and other exams were consistent with the results from other tests, including the large database collected from tests performed on shorter pins in the Experimental Breeder Reactor II.

Future work could include further study of gas release using other MFF pins, including the colder operating pins from MFF-2 and/or MFF-6. Likewise the axial fuel growth could be further examined for links to operating temperature by producing neutron radiographs of pins from MFF-2 and MFF-6. 
INTENTIONALLY BLANK 


\section{AKNOWLEDGEMENTS}

The authors would like to thank all of those who made these experiments possible, including the skilled craftsmen in INL's Fuel Manufacturing Facility (FMF) - fuel slug fabrication; those at the Hanford Westinghouse Hanford Company (WHC) who fabricated the fuel pins and experiment assemblies; Ron Baker, who led the effort to qualify U-10Zr metallic fuel for use in FFTF, supported by Jim Dittmer (fabrication), 'MFF' experimenter Al Pitner and others as well as the WHC analysts whose calculations guided reactor placement and flow to produce the right operating conditions, and provided the safety analysis to provide a basis to allow the experiments be irradiated. Jim Corrigan led this team of analysts which included A. E. Bridges and others.

The authors would also like to thank all those who performed expert characterization of the as-irradiated pins in the Hot Fuel Examination Facility and the Analytical Laboratory at the INL's Materials and Fuels Complex. HFEF engineers Glen Papaioannou, Paul Lind, Katelyn Wachs and David Sell from HFEF are especially to be thanked. 
INTENTIONALLY BLANK 


\section{CONTENTS}

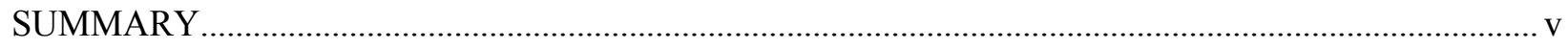

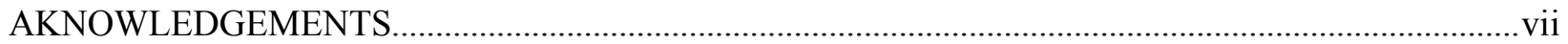

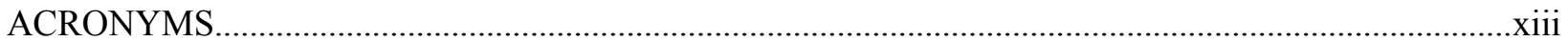

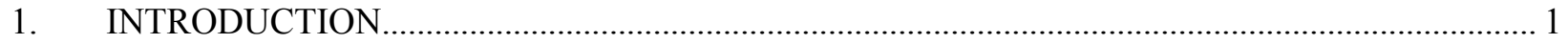

2. MFF-3 AND MFF-5 DESIGN AND OPERATING CONDITIONS.............................................. 2

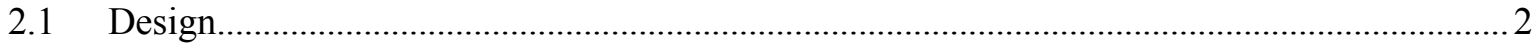

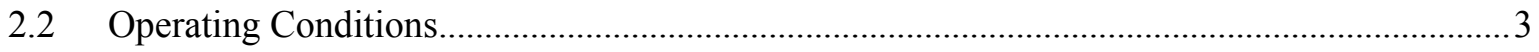

2.2.1 Assembly Burnup Calculations................................................................................ 3

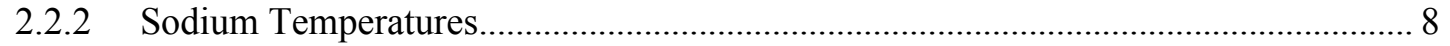

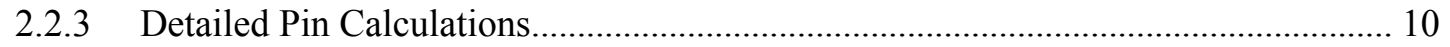

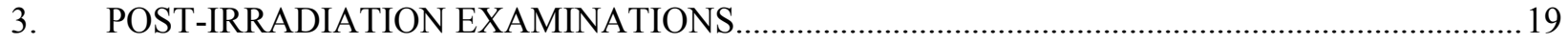

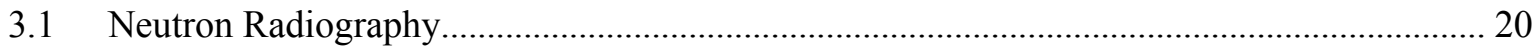

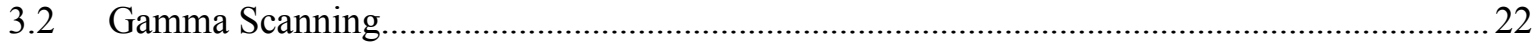

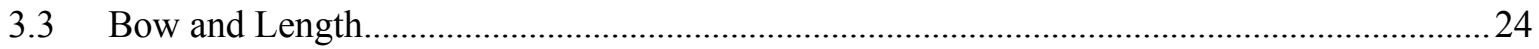

$3.4 \quad$ Element Spiral Contact Profilometer (ESP) ........................................................................26

3.5 Element Linear Contact Profilometer (ECP) ...................................................................... 29

3.6 Plenum Gas Pressure and Composition (GASR Analysis)................................................... 31

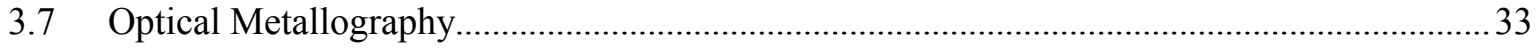

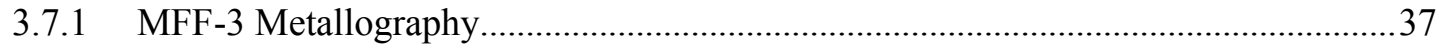

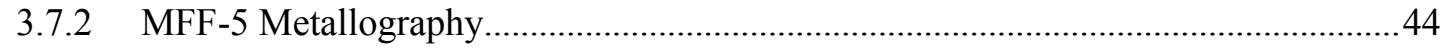

3.7.3 Cladding Metallography and Fuel/cladding Chemical Interaction (FCCI)................. 49

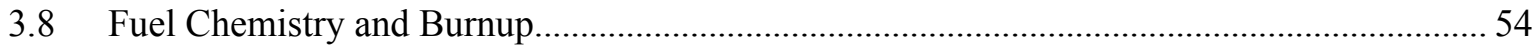

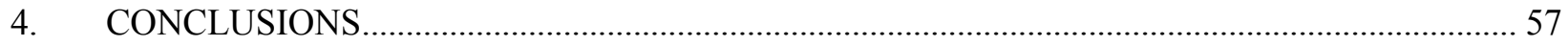

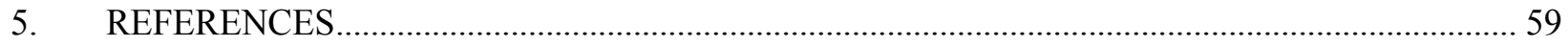

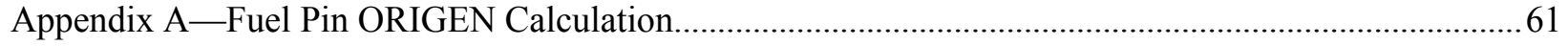

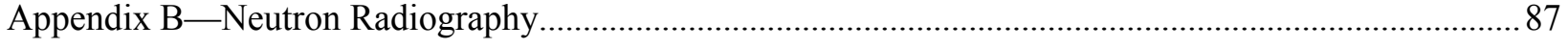

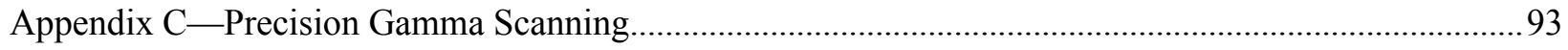




\section{FIGURES}

Figure 1. FFTF Core Loading for Cycle 10C-1; MFF-3 highlighted in green

Figure 2. FFTF Core Loading for Cycle 11B-1; MFF-3 highlighted in green; MFF-5 highlighted in blue. 5

Figure 3. Ratio of axial assembly power to average (from Ref. 6).....

Figure 4. MFF-3 Assembly power and outlet temperature (calculated and measured) at beginning (B) and/or end (E) of reactor cycle...

Figure 5. MFF-5 Assembly power and outlet temperature (calculated and measured) at beginning (B) and/or end (E) of reactor cycle...

Figure 6. Pin loading of the MFF-3 assembly. The location of the assembly index notch in shown, as are the pins selected for composition calculation (in red)...

Figure 7. Pin loading of the MFF-5 assembly. The location of the assembly index notch in shown,

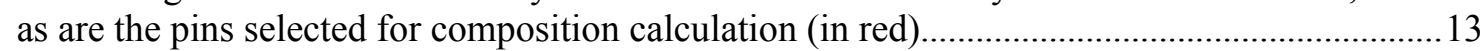

Figure 8. MFF-3, Pin Number 193045, pin power as a function of FFTF cycle number............................ 16

Figure 9. MFF-3, Pin Number 193045 peak inner cladding temperature, in ${ }^{\circ} \mathrm{C}$, as a function of FFTF cycle number.

Figure 10. MFF-3, Pin Number 193045 inner cladding, fuel centerline and fuel surface temperatures, as well as pin power as a function of axial position on the pin. Values are averaged over the total EFPDs.

Figure 11. MFF-5, Pin Number 195011, pin power as a function of FFTF cycle number... .18

Figure 12. MFF-5, Pin Number 195011 peak inner cladding temperature, in ${ }^{\circ} \mathrm{C}$, as a function of FFTF cycle number. 18

Figure 13. MFF-5, Pin Number 195011, inner cladding, fuel centerline and fuel surface temperatures, as well as pin power as a function of axial position on the pin. Values are averaged over the total EFPDs.

Figure 14. Neutron radiography of the tops of the fuel columns of two MFF-3 and two MFF-5 pins, showing the low axial growth compared to a typical IFR-1 pin $(36 \mathrm{in} .=91.4 \mathrm{~cm}$, the initial fuel column length).

Figure 15. Assembly MFF-2 outlet temperatures; cycle 10B (from Ref. 13). 22

Figure 16. Gamma scan traces for Pin 193045 from MFF-3. Neutron radiograph is superimposed.

Figure 17. Gamma scan traces for Pin 195011 from MFF-5. Neutron radiograph is superimposed.

Figure 18. Sketch for the reference frame and measurement coordinates used to record bow and length data. .25

Figure 19. Spiral contact profilometry for MFF-3 Pin 193020 ................................................................. 26

Figure 20. Spiral contact profilometry for MFF-3 Pin 193025 ................................................................... 27

Figure 21. Spiral contact profilometry for MFF-3 Pin 193062 ................................................................... 27

Figure 22. Spiral contact profilometry for MFF-5 Pin 195012 _................................................................ 28 


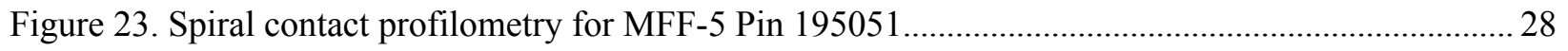

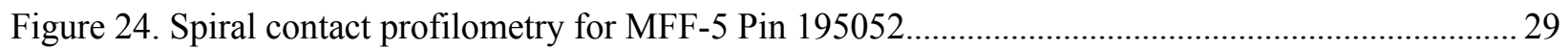

Figure 25. Linear contact profilometry of Pin 193045. Four scans shown as pin is rotated $45^{\circ}$ between scans. Much of the plenum is not shown to emphasize the fuel column.................. 30

Figure 26. Linear contact profilometry of Pin 195011. Four scans are shown as pin is rotated $45^{\circ}$ between scans. Much of the plenum is not shown to emphasize the fuel column

Figure 27. Sectioning diagram for Pins 193045 and 195011. The detailed cuts show where metallography and burnup samples were taken. Location dimensions are in inches. 34

Figure 28. Metallography summary for MFF-3 Pin 193045 showing axial location and operating conditions. Operating conditions are time averaged. .35

Figure 29. Metallography summary for MFF-5 Pin 195011 showing axial location and operating conditions. Operating conditions are time averaged. .36

Figure 30. Metallographic section of MFF-3 Pin 193045 at the $\mathrm{X} / \mathrm{L}=0.03$ axial location........................ 38

Figure 31. Metallographic section of MFF-3 Pin 193045 at the $\mathrm{X} / \mathrm{L}=0.24$ axial location........................ 39

Figure 32. Portion of the U-Zr phase diagram important to U-Zr zone formation (from Ref. 13)............. 40

Figure 33. Metallographic section of MFF-3 Pin 193045 at the $\mathrm{X} / \mathrm{L}=0.49$ axial location........................ 41

Figure 34. Metallographic section of MFF-3 Pin 193045 at the $\mathrm{X} / \mathrm{L}=0.74$ axial location........................ 42

Figure 35. Metallographic section of MFF-3 Pin 193045 at the $\mathrm{X} / \mathrm{L}=0.98$ axial location........................ 43

Figure 36. Area of fuel/cladding chemical interaction (FCCI) in the $\mathrm{X} / \mathrm{L}=0.98$ cross-section of Pin 193045. 44

Figure 37. Metallographic section of MFF-5 Pin 195011 at the $\mathrm{X} / \mathrm{L}=0.03$ axial location. 45

Figure 38. Metallographic section of MFF-5 Pin 195011 at the $\mathrm{X} / \mathrm{L}=0.24$ axial location. 46

Figure 39. Metallographic section of MFF-5 Pin 195011 at the $\mathrm{X} / \mathrm{L}=0.48$ axial location. 47

Figure 40. Metallographic section of MFF-5 Pin 195011 at the $\mathrm{X} / \mathrm{L}=0.74$ axial location. 48

Figure 41. Metallographic section of MFF-5 Pin 195011 at the $\mathrm{X} / \mathrm{L}=0.96$ axial location. 49

Figure 42. Polished and etched surface cut across diffusion couple of U-Pu-Zr fuel and HT9 cladding. $705^{\circ} \mathrm{C}$ for $300 \mathrm{hr}$. Large hardness indents show soft, decarburized area of large-grain ferrite in the HT9. .50

Figure 43. MFF-3 Pin 193045 HT9 cladding microhardness as a function of axial location. 51

Figure 44. MFF-5 Pin 195011 HT9 cladding microhardness as a function of axial location. 52

Figure 45. Fuel/Cladding Chemical Interaction (FCCI) in MFF-5 Pin 195011. Shown are measured peak FCCI, predicted FCCI, and both time-averaged inner clad and fuel centerline temperatures. ${ }^{17}$

Figure 46. Heavy metal burnup as a function of axial location as calculated (ORIGEN) and measured (average of isotopic analyses). MFF-3 Pin 193045 and MFF-5 Pin 195011 are represented.

Figure 47. Tc-99 content after irradiation as a function of axial location as calculated (ORIGEN) and measured (AL-Analytical Chemistry). MFF-3 Pin 193045 and MFF-5 Pin 195011 are represented. 


\section{TABLES}

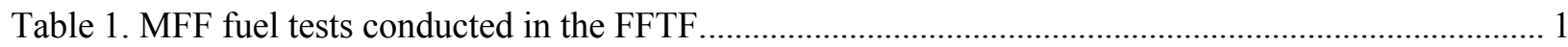

Table 2. MFF-3 and MFF-5 fuel pin design characteristics.......................................................................2

Table 3. MFF-3 and MFF-5 initial assembly conditions.........................................................................5

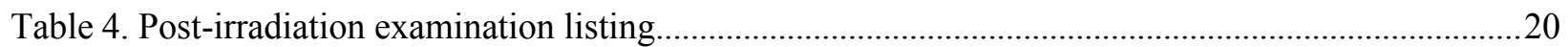

Table 5. Axial growth of active fuel column as determined by neutron radiography.................................22

Table 6. 'Hanging' lengths of pins before and after irradiation..................................................................... 26

Table 7. Fission gas pressure and volume measured for IFR-1 fuel pins...................................................... 32

Table 8. Fission gas composition of the MFF-3 and MFF-5 pins punctured for analysis............................ 33

Table 9. Isotopic ratios of the fission gas of the MFF-3 and MFF-5 fuel pins..............................................33

Table 10. MFF-3 (193045) metallographic section operating conditions..................................................... 37

Table 11. MFF-5 (195011) metallographic section operating conditions................................................... 37

Table 12. Fuel/cladding interaction layer depth as a function of axial position...........................................53

Table 13. Summary fuel burnups (heavy metal) computed from measured isotopic concentration measurements for isotopes thought to be most reliable for burnup determination........................ 55 


\section{ACRONYMS}

BOC beginning of cycle

BOL beginning-of-life

EBLM element bow and length machine

EBR-II Experimental Breeder Reactor-II

ECP element contact profilometry

EFPD effective full power day(s)

ELP element laser profilometry

EOC end of cycle

EOL end-of-life

EPMA electron probe microanalysis

FCCI fuel/cladding chemical interaction

FCRD Fuel Cycle Research and Development

FCMI Fuel/cladding mechanical interaction

FMF Fuel Manufacturing Facility

FFTF Fast Flux Test Facility

GASR gas assay sample and recharge system

HEU highly enriched uranium

HFEF Hot Fuel Examination Facility

IFR Integral Fast Reactor

INL Idaho National Laboratory

MOX mixed oxide (fuel)

NADB nuclear analysis database

PNNL Pacific Northwest National Laboratory

RDR Reload Design Report

RFR relative fission rate

SFR sodium fast reactor

TFR total fission rate

WHC Westinghouse Hanford Company 
INTENTIONALLY BLANK 


\section{Examination of Legacy Metallic Fuel Pins (U-10Zr) Tested in FFTF \\ 1. INTRODUCTION}

In the 1980s and early 1990s there was a resurgence of interest in using metallic fuel in sodium-cooled fast reactors. It was shown to provide economic and simplicity benefits in initial fabrication and also in reprocessing as well as reactor safety benefits, resulting in the Integral Fast Reactor program. ${ }^{1}$ These were reviewed in a recent article on the fast reactor fuels tests performed in the United States. ${ }^{2}$ Most all of the testing was performed in the Experimental Breeder Reactor-II (EBR-II), especially involving the ternary fuel alloy U-xPu-10Zr. Only one such test of ternary fuel, named IFR-1, was performed in the Fast Flux Test Facility (FFTF) reactor, to show behavior of prototypic length fuel pins. ${ }^{3}$

Another important set of full (prototypic)-length 169-pin experiments, using U-10Zr metallic fuel clad with ferritic/martensitic HT9 stainless steel, were also performed in the FFTF reactor. They were part of a test series, named the 'MFF' experiments, designed to qualify this fuel, named the 'Series III.b' design, for general use as driver fuel in the FFTF. ${ }^{4}$ Seven of the planned tests were conducted, their operating conditions summarized in Table 1.

Table 1. MFF fuel tests conducted in the FFTF.

\begin{tabular}{|l|c|c|c|l|l|}
\hline \multicolumn{1}{|c|}{ Test } & $\begin{array}{c}\text { Peak Linear } \\
\text { Power } \\
(\mathrm{kW} / \mathrm{m})\end{array}$ & $\begin{array}{c}\text { Peak Clad } \\
\text { Temperatur } \\
\mathrm{e} \\
\left({ }^{\circ} \mathrm{C}\right)\end{array}$ & $\begin{array}{c}\text { Test Duration } \\
(\mathrm{EFPD})\end{array}$ & $\begin{array}{c}\text { Peak Burnup } \\
(\mathrm{MWd} / \mathrm{KgM})\end{array}$ & $\begin{array}{c}\text { Fast }(\mathrm{E}>0.1 \mathrm{MeV}) \\
\text { Fluence } 10^{22} \mathrm{n} / \mathrm{cm}^{2}\end{array}$ \\
\hline MFF-1 & 42.7 & 577 & 250 & 38 & 5.6 \\
\hline MFF-1A & 43.0 & 577 & 685 & 95 & 17.3 \\
\hline MFF-2 & 54.1 & 618 & 853 & 143 & 19.9 \\
\hline MFF-3 & 59.1 & 643 & 726 & 138 & 19.2 \\
\hline MFF-4 & 56.8 & 618 & 726 & 135 & 19.0 \\
\hline MFF-5 & 55.8 & 649 & 503 & 101 & 14.0 \\
\hline MFF-6 & 55.8 & 588 & 503 & 95 & 12.8 \\
\hline
\end{tabular}

The tests were supposed to bracket the potential operating conditions if used as an FFTF driver fuel, so some of the test were operated with elevated peak cladding temperatures. These were MFF-3 and MFF-5. In fact these two tests operated with HT9 cladding temperatures hotter than all but one of the EBR-II tests (X447), ${ }^{5}$ and at the shut-down of the FFTF were never planned to be examined. The current Fuel Cycle Research and Development (FCRD) program recognized their potential worth and some pins were set aside at the time the others were being conditioned as used fuel.

The purpose of this report is to detail the post-irradiation examination of several fuel pins from the MFF-3 and MFF-5 experiments. 


\section{MFF-3 AND MFF-5 DESIGN AND OPERATING CONDITIONS 2.1 Design}

An outline the design of fuel pins used in the MFF-3 and MFF- 5 tests is shown in Table 2. MFF-5 also had a shorter Inconel reflector below the fuel slugs, requiring modifying subassembly internal characteristics to axially center the fuel in the FFTF core.

Table 2. MFF-3 and MFF-5 fuel pin design characteristics.

\begin{tabular}{|c|c|c|}
\hline & \multirow[b]{2}{*}{ MFF-3 } & \multirow[b]{2}{*}{ MFF-5 } \\
\hline & & \\
\hline \multicolumn{3}{|l|}{ Fuel Slug } \\
\hline diameter (mm) & 4.98 & 4.98 \\
\hline length $(\mathrm{cm})$ & 91.4 & 91.4 \\
\hline composition & U-10Zr & U-10Zr \\
\hline density $\left(\mathrm{g} / \mathrm{cm}^{3}\right)$ & 15.8 & 15.8 \\
\hline mass slug (g) & 281.3 & 281.3 \\
\hline $\mathrm{wt} \% \mathrm{U}$ & 90 & 90 \\
\hline mass U $(\mathrm{g})$ & 253.2 & 253.2 \\
\hline${ }^{235} \mathrm{U}$ enrichment (\%) & 32.4 & 31.0 \\
\hline $\operatorname{mass}{ }^{235} \mathrm{U}(\mathrm{g})$ & 82.05 & 78.5 \\
\hline mass ${ }^{238} \mathrm{U}(\mathrm{g})$ & 171.1 & 174.7 \\
\hline $\mathrm{wt} \% \mathrm{Zr}$ & 10 & 10 \\
\hline mass $\mathrm{Zr}(\mathrm{g})$ & 28.1 & 28.1 \\
\hline \multicolumn{3}{|l|}{ Axial Reflector } \\
\hline material & Inconel & Inconel \\
\hline number & 1 & 1 \\
\hline diameter (mm) & 4.81 & 4.81 \\
\hline length $(\mathrm{cm})$ & 16.5 & 6.4 \\
\hline \multicolumn{3}{|l|}{ Cladding } \\
\hline $\mathrm{OD}(\mathrm{mm})$ & 6.86 & 6.86 \\
\hline thickness (mm) & 0.559 & 0.559 \\
\hline Wire wrap diameter/pitch $(\mathrm{mm} / \mathrm{cm})$ & $1.35 / 15.24$ & $1.35 / 22.86$ \\
\hline material & HT-9 & HT-9 \\
\hline \multicolumn{3}{|l|}{ Other Characteristics } \\
\hline sodium fill above fuel $(\mathrm{cm})$ & 2.54 & 2.54 \\
\hline Total Pin Length $(\mathrm{cm})$ & 238 & 237 \\
\hline smeared density, $\%$ & 75.2 & 75.2 \\
\hline gas plenum volume $\left(\mathrm{cm}^{3} @ 25^{\circ} \mathrm{C}\right)$ & 28.9 & 31.5 \\
\hline
\end{tabular}




\subsection{Operating Conditions}

When it was decided that examination of MFF-3 and -5 pins would be done, the as-run conditions for the two assemblies and for each fuel pin were calculated. The calculations were performed at the Pacific Northwest National Laboratory (PNNL). Assembly conditions were modified cycle-by-cycle as influenced by reactor power and the changes to the core loading (influences of neighboring assemblies). From these, sodium temperatures associated with the two assemblies could be calculated. Finally detailed pin-by-pin conditions could be calculated.

Details of the analysis can be found elsewhere. ${ }^{6}$ The following summarizes the calculated operating conditions and calculation methods.

\subsubsection{Assembly Burnup Calculations}

Previous burnup calculations for FFTF assemblies used in Core Reload Design Reports were based on two dimensional methods. Burnup calculations for this study for MFF-3 and MFF-5 were accomplished with a sequence of three-dimensional calculations to provide more accurate axial treatment. Starting with a beginning of cycle (BOC) nuclear analysis database (NADB), completion of this sequence results in an end of cycle (EOC) NADB. The EOC NADB is updated to give an NADB for the beginning of the next cycle by accounting for decay of ${ }^{241} \mathrm{Pu}$ between cycles and manually updating the NADB loading file to include the core loading changes.

The burnup calculations were based on actual core loadings and irradiation histories, not predicted or planned values. Also, data presented in tables and figures in this section were based on three-dimensional (3D) models, whereas the Reload Design Report (RDR) calculations were based on 2D models, with approximate 3D axial factors applied when needed.

The flux calculations that were part of the burnup calculation sequence were made with the control rod bank positioned at nominally the cycle averaged position. Sometimes for short cycles these calculations were the source of BOC flux and power distributions used in generating the data. For the other cycles, separate runs for the BOC were made. In all cases where EOC data were reported, separate runs were made.

After all the runs to generate the required flux and power distributions were completed, six post-processing runs were made for the BOC or EOC of each cycle reported to generate the data tables. Data generated for MFF-3 and MFF-5 include:

- Assembly fission powers, fast neutron fluxes ( $>0.1 \mathrm{MeV}$ ), total fluxes

- Radial spatial distributions of fast flux and fission power by pin

- Axial power, total flux, and fast flux distributions

- Fast flux at the duct walls

- Burnup dependent material compositions for six axial segments.

MFF-3 was inserted into the FFTF core at the beginning of Cycle 10C and was irradiated for 726.2 effective full-power days (EFPD) and MFF-5 was inserted for the beginning of Cycle 11B-1 and was irradiated for 503 EFPD. Figure 1 and Figure 2 show the FFTF core loadings for the cycles in which the tests were inserted. The initial operating conditions for each of the two subassemblies are listed in Table 3. 


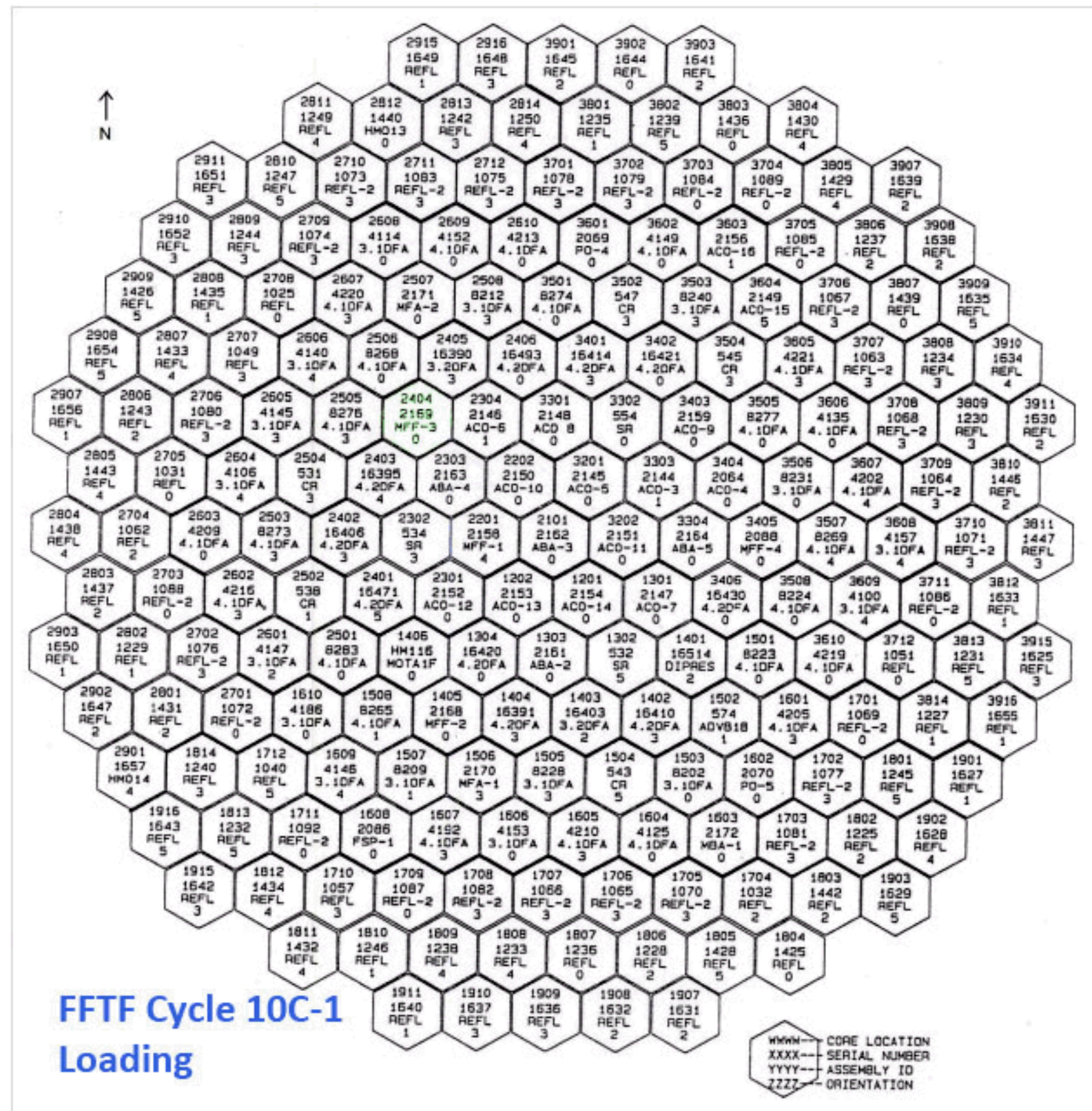

Figure 1. FFTF Core Loading for Cycle 10C-1; MFF-3 highlighted in green. 


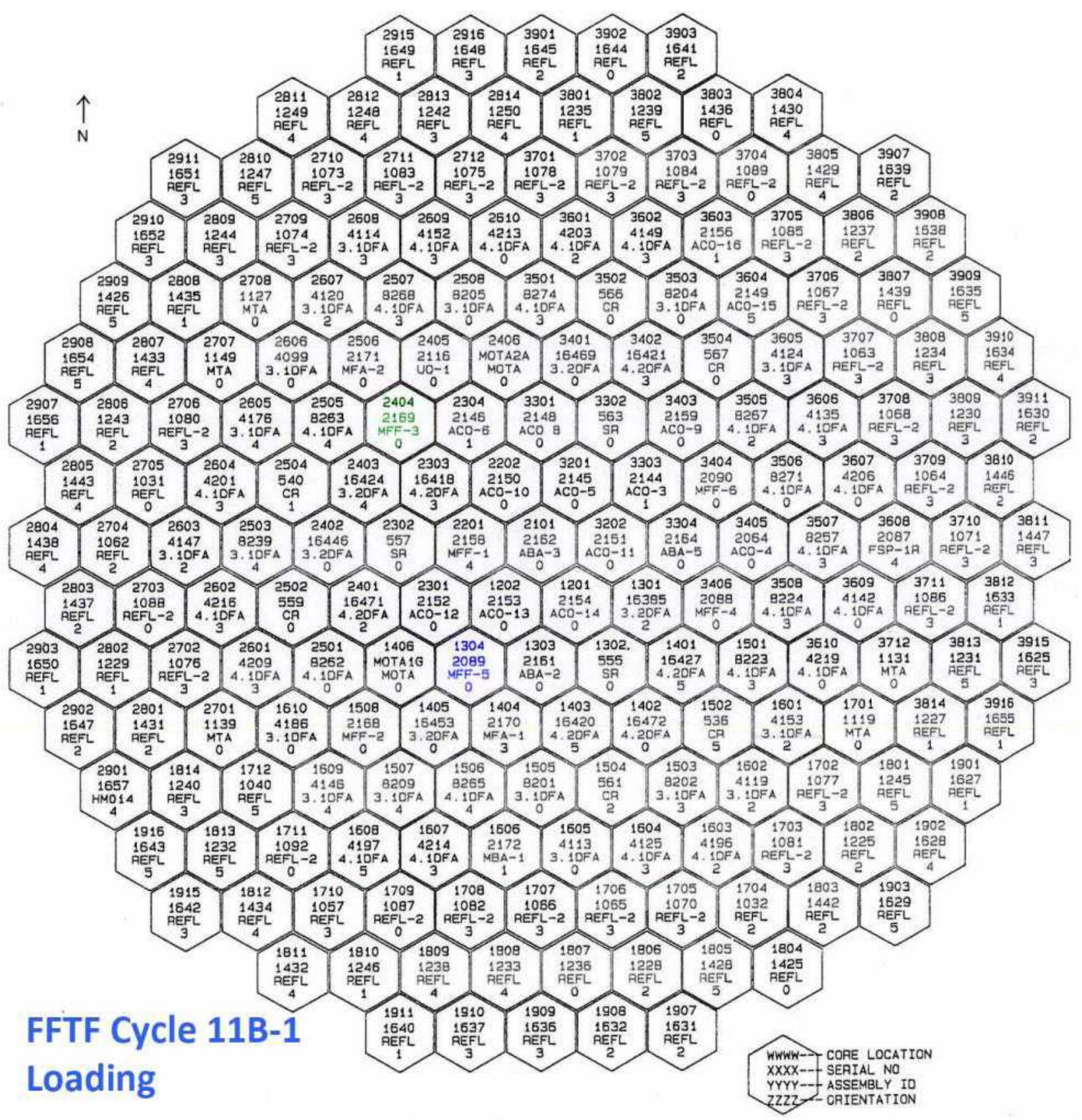

Figure 2. FFTF Core Loading for Cycle 11B-1; MFF-3 highlighted in green; MFF-5 highlighted in blue.

Table 3. MFF-3 and MFF-5 initial assembly conditions.

\begin{tabular}{|c|c|c|c|c|c|}
\hline Test & Test Start & $\begin{array}{c}\text { Core } \\
\text { Position }\end{array}$ & $\begin{array}{c}\text { S/A Outlet } \\
\mathrm{T}\left({ }^{\circ} \mathrm{C}\right)\end{array}$ & $\begin{array}{c}\text { Sodium Flow Rate } \\
\left(\mathrm{m}^{3} / \mathrm{hr}\right)\end{array}$ & $\begin{array}{c}\text { S/A Power } \\
(\mathrm{MW})\end{array}$ \\
\hline MFF-3 & $10 \mathrm{C}(\mathrm{BOC})^{*}$ & 2404 & 580 & 110 & 7.94 \\
\hline MFF-5 & $11 \mathrm{~B}-1(\mathrm{BOC})$ & 1304 & 564 & 108 & 7.55 \\
\hline
\end{tabular}

$* 10 \mathrm{C}(\mathrm{BOC})=$ FFTF Cycle $10 \mathrm{C}$ at the Beginning of Cycle. 
The assembly conditions were tracked cycle-by cycle, calculating the following conditions for the beginning and end of cycle (BOC and EOC).

- $\quad$ Fission Power Generated in MFF-3, MFF-5 and Neighboring Assemblies

- Assembly Averaged Fast and Total Flux for MFF-3 and MF3-5

- Axial Distribution of Total Flux, Fast Flux and Power in MFF-3

- Axial Distribution of Total Flux, Fast Flux and Power in MFF-5

- Fission Power Distribution by Pin in MFF-3

- Fission Power Distribution by Pin in MFF-5

- $\quad$ Fast Flux Distribution by Pin in MFF-3

- Fast Flux Distribution by Pin in MFF-5

- MFF-3 and MFF-5 Duct Wall Flux Greater than $0.1 \mathrm{MeV}$

- Fission Fractions by Isotope in MFF-3 and MFF-5.

The MFF-3 and -5 compositions were compiled for the end of each cycle.

The ratio of the axial assembly power to the average is shown for in Figure 3 for MFF-3(BOL); similar profiles would be expected for MFF-5 and at other points in the irradiation history of each.

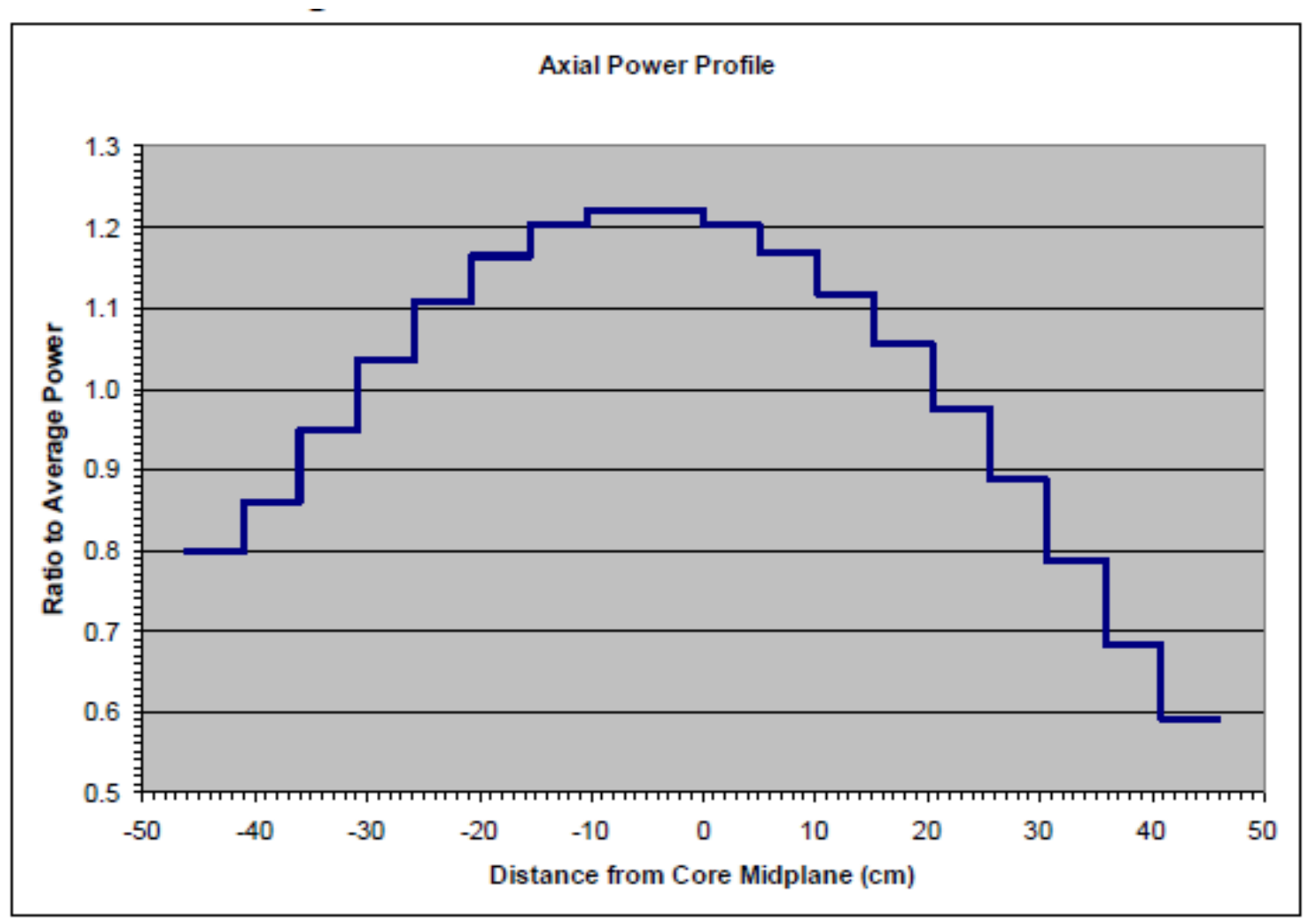

Figure 3. Ratio of axial assembly power to average (from Ref. 6). 


\subsubsection{Assembly Fission Rates}

First, the assembly-averaged fission rate, $\mathrm{FR}_{\mathrm{i}}$, (fissions $/ \mathrm{sec}$ per $\mathrm{cm}^{3}$ ) for each of the seven fissionable isotopes, $\mathrm{i}$, was computed (approximately) using the equation:

$$
\begin{aligned}
& \text { G } \\
& \mathrm{FR}_{\mathrm{i}}=\mathrm{N}_{\mathrm{i}} \Sigma \sigma_{\mathrm{i}, \mathrm{g}} \theta_{\mathrm{g}} \\
& \mathrm{g}=1
\end{aligned}
$$

where

$$
\begin{aligned}
\mathrm{N}_{\mathrm{i}}= & \text { the average atom density (atoms per barn-cm) of isotope } \mathrm{i} \text { in MFF-3 or MFF-5 at a } \\
& \text { particular point in time, } \\
\sigma_{\mathrm{i}, \mathrm{g}}= & \text { the fission cross section of isotope } \mathrm{i} \text { in energy group g, } \\
\theta_{\mathrm{g}}= & \text { the average neutron flux (neutrons/cm2-sec) in MFF-3 or MFF-5 at a particular point in } \\
& \text { time, and } \\
\mathrm{G}= & \text { the number of neutron energy groups (12) }
\end{aligned}
$$

Next, the total fission rate, FRT, averaged over an assembly was computed as the sum of the seven values of RFi computed using the equation above. Then the relative fission rate of each of the seven fissionable isotopes, RFRi, was computed as:

$$
\mathrm{RFR}_{\mathrm{i}}=\mathrm{FR}_{\mathrm{i}} / \mathrm{FR}_{\mathrm{T}}
$$

The equation used for computing the $\mathrm{FR}_{\mathrm{i}}$ values is an approximation (except for BOL conditions) because of the axial variation in the buildup or depletion on the isotopes. Thus, the $\mathrm{FR}_{\mathrm{T}}$ was not used to obtain the total fission rates listed in the tables. However, the $\mathrm{RFR}_{\mathrm{i}}$ values tabulated are reasonably accurate because most of the effect of axial burnup variation is divided out in obtaining the relative values.

The total fission rate, TFR, (fissions/sec) in an assembly (MFF-3 or MFF-5) was computed from the adjusted fission power, $\mathrm{P}$, (MW) produced in the assembly using the equation:

$$
\mathrm{TFR}=\mathrm{P} \times \mathrm{C} / \mathrm{FE}
$$

where

$$
\begin{aligned}
& \mathrm{C}=\text { the factor for converting power in } \mathrm{MW} \text { to units of } \mathrm{MeV} / \mathrm{sec} \\
& \mathrm{C}=6.24146 \times 10^{18} \mathrm{MeV} \text { per MW-sec, and } \\
& \mathrm{FE}=\text { fission energy ( } 212 \mathrm{MeV} / \text { fission })
\end{aligned}
$$

Burnup-dependent material compositions for MFF-3 and MFF-5 were calculated at the end of each cycle. The burnup-dependent compositions for the fuel were computed using the three dimensional diffusion theory and burnup codes 3DBF and BURN3D. ${ }^{7}$ The fuel was subdivided into six axial regions to properly account for the effect that the axial flux distribution has on the fuel depletion rate. The composition data included fuel, fission products and stainless steel components. 


\subsubsection{Sodium Temperatures}

\subsubsection{Methods}

The calculation of sodium temperatures with the SUPERENERGY code based on two dimensional diffusion theory methods ${ }^{8}$ with generic axial flux and power profiles from 3-D calculations was a normal part of the core reload design process. The results of these calculations were reported in core reload design and operating reports for Cycles 10C through 12B.

There were two sources of sodium temperature analyses for MFF-3 and MFF-5. The output files of SUPERENERGY temperature calculations that were previously part of the core reload design process for Cycles 11A through 12B were located, and the outlet temperatures and subchannel temperatures for MFF-3 and MFF-5 for these cycles were obtained from these files. No SUPERENERGY output files were available for Cycle 10C. Therefore, the full calculational sequence was performed to generate the temperature distributions for BOC 10C-1 and EOC 10C-3 for MFF-3 and MFF-5.

Data provided for MFF-3 and MFF-5 for each BOC and EOC include:

- Assembly outlet temperatures

- Sodium subchannel temperatures at three axial elevations corresponding to the top of the fuel column, the top of the upper axial reflector in driver fuel pins, and the top of the fuel pin bundle.

The SUPERENERGY code is a subchannel code that was designed specifically for hexagon shaped, wire wrapped pin bundles and was used to calculate the FFTF core assembly mixed-mean outlet temperatures, the assembly subchannel temperatures of all core assemblies, the core assembly duct wall temperatures, and the temperature of the reflector assembly coolant channels. The assembly mixed mean outlet temperatures was used as a basis for comparison to the FFTF above-core instrumentation data and to show that the core loading plans are in compliance with FFTF technical specifications prior to reactor operation. Figure 4 and Figure 5 show the calculated assembly power at the beginning and/or end of each reactor cycle /subcycle for MFF-3 and MFF-5, respectively, as well as the assembly outlet temperatures calculated and measured by the above-core instrumentation. Some points were not calculated due to the short cycle run times. Note that the horizontal scale is not linear in time as FFTF cycle length varied.

The relatively steady decrease in assembly power as the fuel burns out is seen for MFF-3 and for MFF-5 is more influenced by changes in the influence of neighboring assemblies. The comparison of the calculated vs. measured assembly outlet temperature has been used to assess the axial fuel growth of the metallic fuel as the calculation models do not account for a drop in linear power density due to axial fuel swelling. ${ }^{9}$ The outlet temperatures measured become lower than expected. However, these two figures show that for MFF-3 and MFF-5 this was not the case. This will be further discussed subsequently in this report when the axial growth data is presented. 


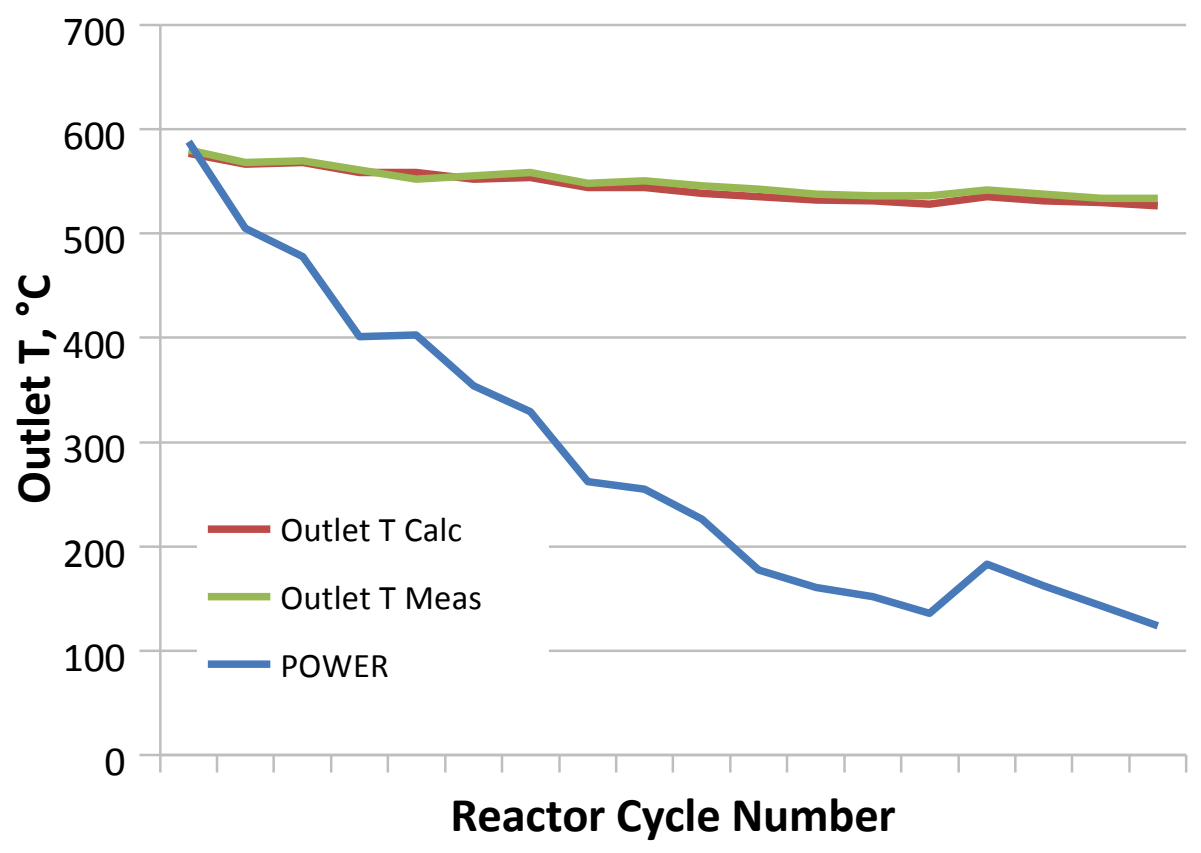

Figure 4. MFF-3 Assembly power and outlet temperature (calculated and measured) at beginning (B) and/or end (E) of reactor cycle.

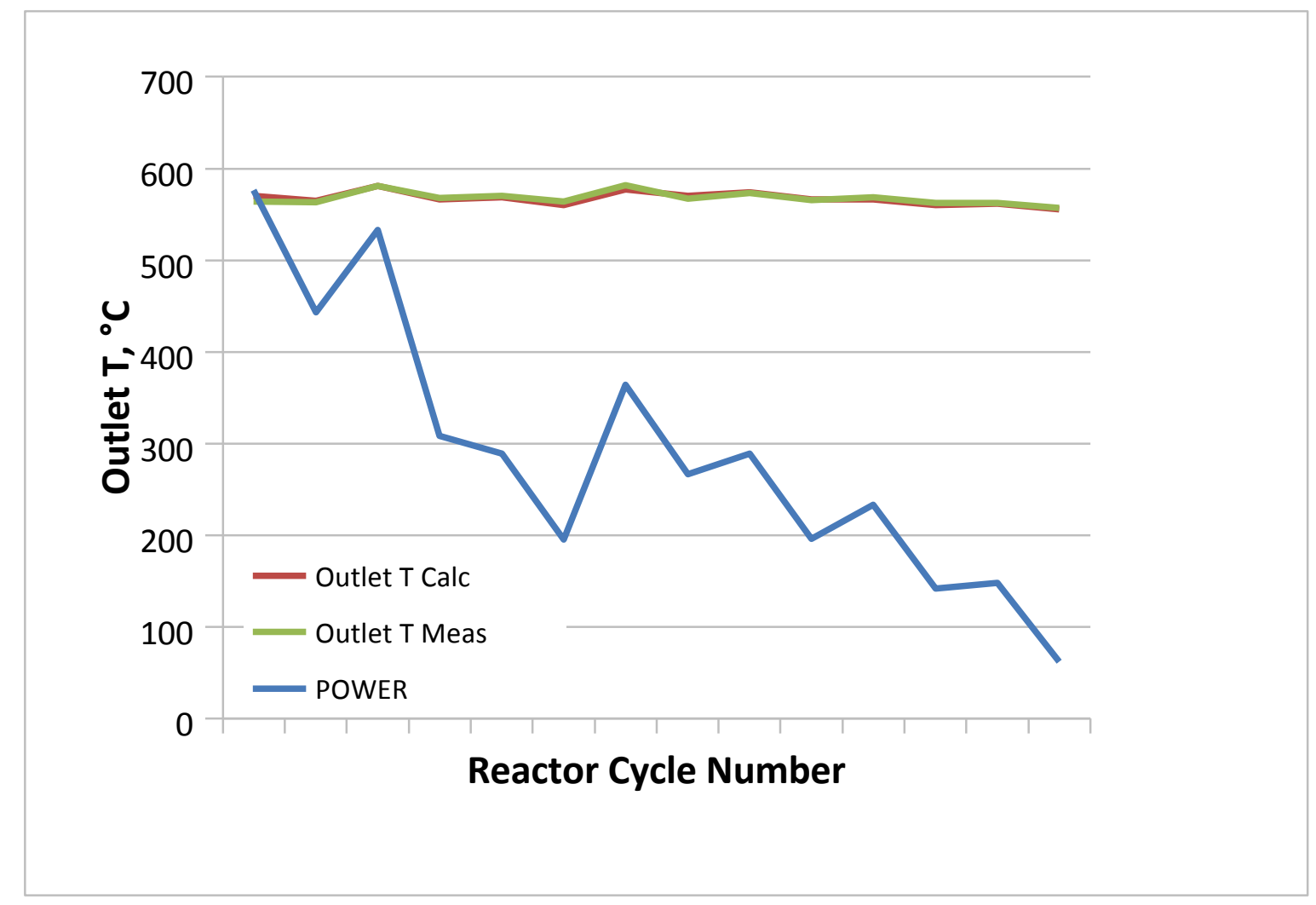


Figure 5. MFF-5 Assembly power and outlet temperature (calculated and measured) at beginning (B) and/or end (E) of reactor cycle.

The subchannel temperatures are used in design analyses of test pins, post-irradiation data correlation of test pins, and for lifetime analyses of driver fuel pins. The duct wall temperatures are used in the structural analyses of the individual assemblies and of the core restraint system. The flow field is described in terms of two correlated parameters, a subchannel mixing parameter and a swirl flow parameter. These two parameters, along with the energy equation and a subchannel flow split model, can completely describe the temperature field in a pin bundle without the use of momentum and continuity. The mixing parameters and flow split correlations are based on extensive experimental test data.

The subchannel temperatures were calculated for MFF-3 and MFF-5 in all subchannels of the fuel bundle and at each cycle, except again for very short cycles. These could then be used to choose, for example, the hottest operating pins in the bundle.

\subsubsection{Detailed Pin Calculations}

\subsubsection{Methods}

Details of the pin burnup calculation methods can be found elsewhere.6 Data for specific pins in MFF-3 and MFF-5 during their residence in the FFTF core and for decay times following discharge were generated based on three-dimensional calculations of detailed irradiation conditions for these pins to help analysts and designers in evaluating these fuel tests. This information would then allow a more detailed interpretation of test results and development of performance correlations and/or models for metallic fuel assemblies.

Obtaining radionuclide inventories involved:

1. Compiling pin information

a. Pins selected in each test assembly for detailed burnup calculations

b. Irradiation history (irradiation and decay times) of each assembly

c. Initial as-built compositions of the selected fuel pins

d. Decay times selected following end of irradiation

2. Generating total flux and effective one-group reaction cross sections for each irradiation cycle for each axial layer of each pin in each assembly.

3. Using the as-built pin compositions along with pin-segment-specific fluxes and cross sections by cycle to generate radionuclide inventories for each fuel pin axial segment at the beginning and end of each irradiation cycle and selected decay times following discharge, accounting for isotope buildup, depletion and radioactive decay.

The length of the fuel column in the three dimensional flux calculations was $92.28 \mathrm{~cm}$, with 18 axial layers in the fuel region, corresponding to layers 12 through 29 in the 3DBF flux model. Individual calculations of pin segments were made using the average flux and cross sections over each of the axial layers, providing eighteen fuel pin segments per pin. Thus, each detailed pin burnup calculation corresponds to a $5.127 \mathrm{~cm}$ long segment of a fuel pin. Data provided for MFF-3 and MFF-5 for the beginning and end of each operating cycle include neutron flux, cross sections, and burnup dependent compositions for 18 axial pin segments for selected fuel pins.

This information was then used in the $\mathrm{SAFE}^{10}$ thermal hydraulic model to calculate axial fuel and cladding temperatures for select pins. 


\subsubsection{Selected Pins}

Nine pins from MFF-3 and ten pins from MFF-5 were selected by INL for detailed burnup calculations. The locations of the selected pins in MFF-3 and MFF-5 are shown in Figure 6 and Figure 7, respectively. 


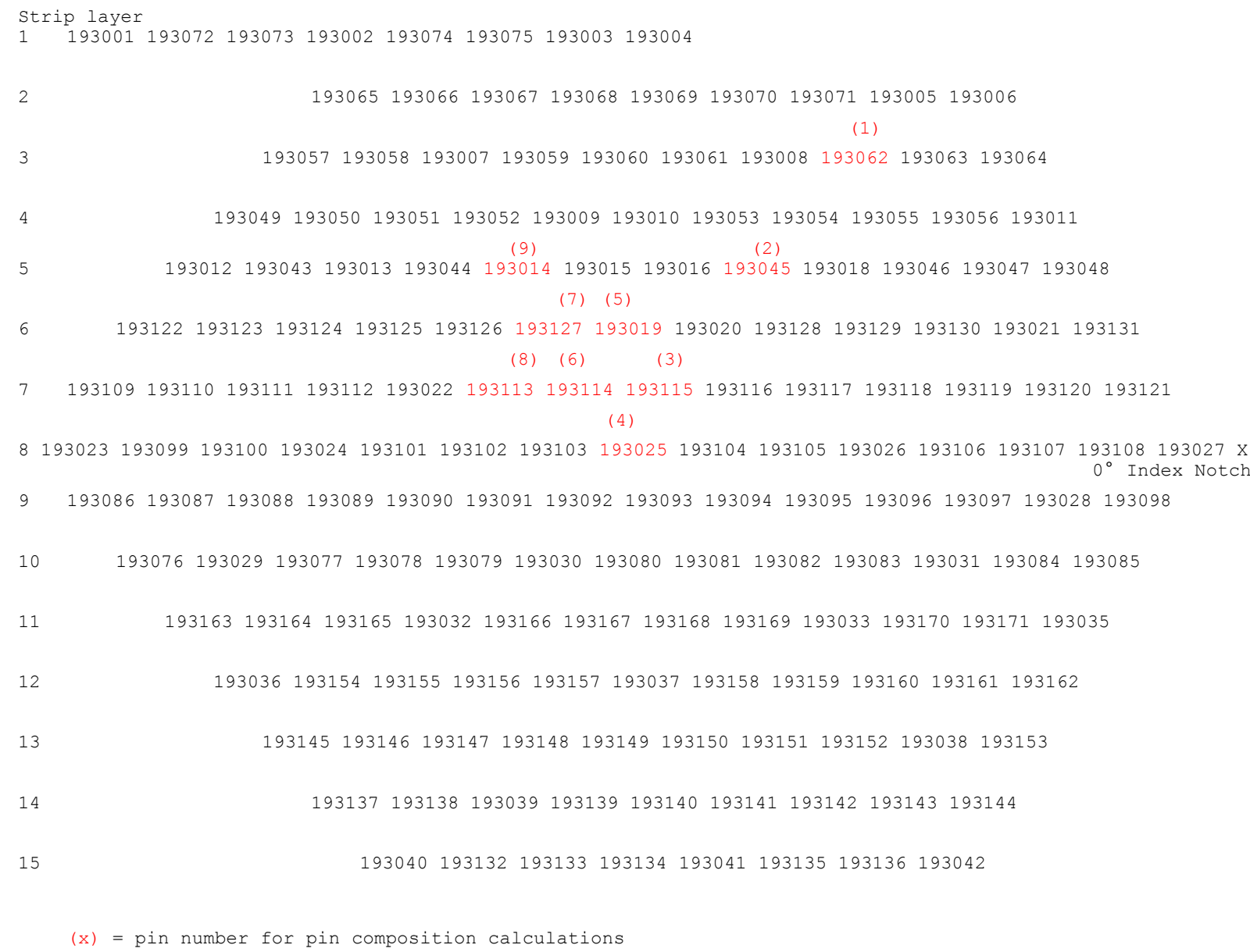

Figure 6. Pin loading of the MFF-3 assembly. The location of the assembly index notch in shown, as are the pins selected for composition calculation (in red). 


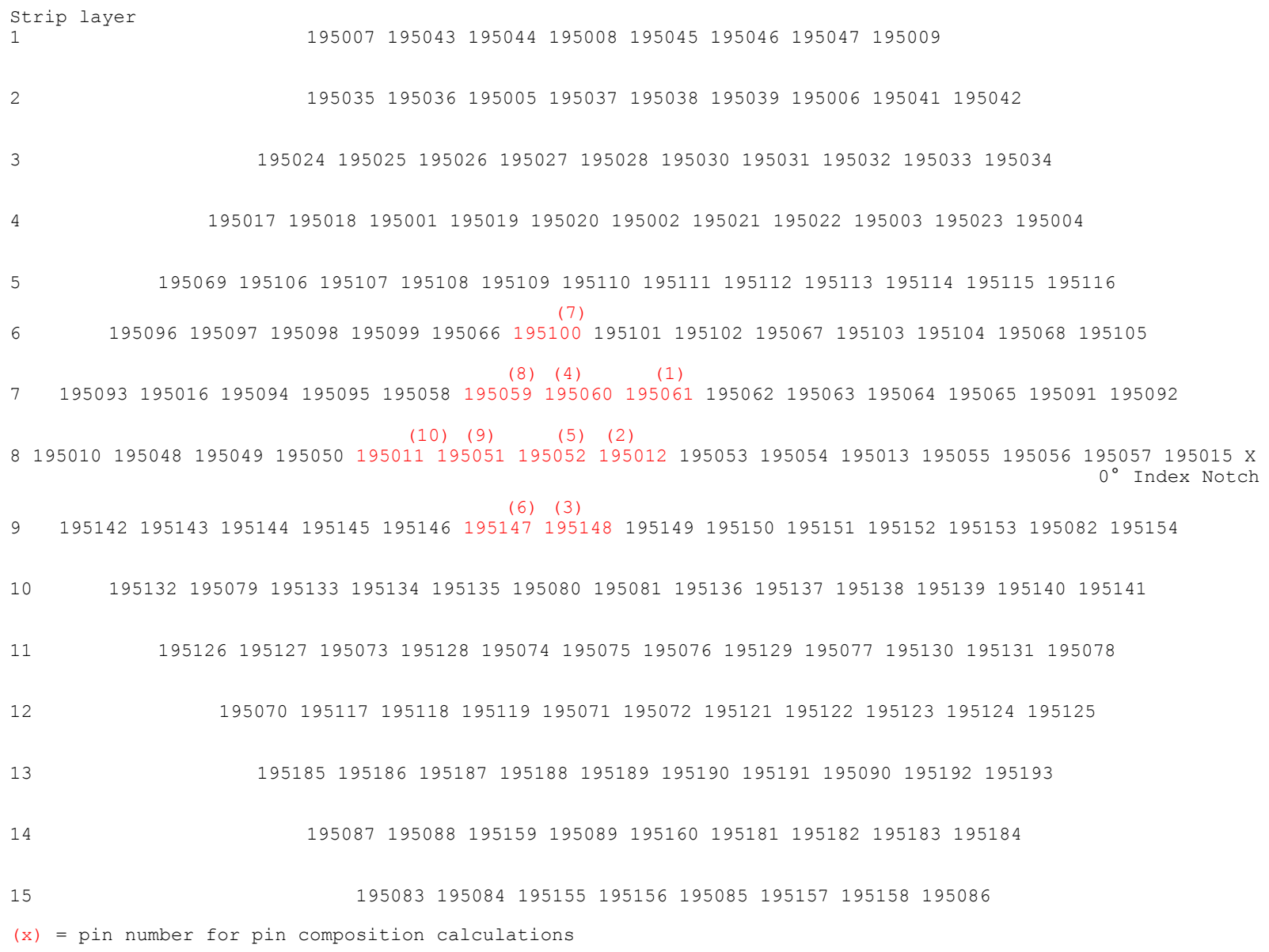

Figure 7. Pin loading of the MFF-5 assembly. The location of the assembly index notch in shown, as are the pins selected for composition calculation (in red). 


\subsubsection{Selected Pin Total Flux}

The effective one-group neutron flux for each cycle and each of 18 axial layers of each pin was calculated by running the HEDPIN code for each of the 18 layers of the fuel column in the 3DBF flux file for each cycle. These fluxes were generated from the same 3DBF flux files with the mid-cycle control rod elevations that were used in the assembly cycle burn calculations that created the nuclear analysis database files (NADBs) for each cycle. 6

\subsubsection{Cross Sections for Axial Segments}

For each of the pin segment total flux values, effective one group fission and capture reaction cross sections for ${ }^{235} \mathrm{U},{ }^{238} \mathrm{U},{ }^{239} \mathrm{Pu},{ }^{240} \mathrm{Pu}$, and ${ }^{241} \mathrm{Pu}$ were generated for each pin segment for each cycle. This was done by running the HEDPIN code on the same 3DBF flux files for each cycle, but this time multiplying the multi-group flux by the metallic fuel test multi-group cross sections to calculate reaction rates instead of total flux, and using the HEDPIN interpolating fit to obtain the values for each pin segment. The effective one group reaction cross sections were then obtained by dividing the reaction rates by the total flux. These pin-segment-cycle-dependent cross sections were substituted into the FFTF metallic fuel specific ORIGEN2 cross section library for each ORIGEN2 calculation.

The ORIGEN2 input files for each pin segment were constructed using the total flux values as constant over each cycle, with actual irradiation times and decay times between each cycle. Nuclide inventories for each pin segment were calculated, which included the beginning and end of each operating cycle and twelve decay times extending out to the year 2040 following the end of irradiation.

\subsubsection{Calculation of Pin Powers}

The peak linear power for each assembly can be calculated by multiplying the assembly fission power, a factor accounting for the difference in the power deposited in the pin (fuel and cladding) and the fission power, and the radial and axial peaking factors. The pin energy deposition for the U-10Zr metallic fuel pins differs from the standard mixed $\mathrm{U} / \mathrm{PuO}_{2}$ fuel pins in FFTF because the ${ }^{235} \mathrm{U}$ enriched pins release less energy per fission than pins driven by ${ }^{239} \mathrm{Pu}$ fission and have a different composition with internal sodium and zirconium. The slightly different pin energy deposition rates for the metallic fuel pins were included in the calculated peak pin powers.

The total heat distribution for the FFTF core (including nonfueled components) is obtained by combining the local direct fission heat production with other nuclear heat sources, such as gamma ray absorption, charged particle reactions, and neutron scattering recoils. The energy produced from all of these sources is combined and adjusted so that the total is properly normalized for a recoverable heat energy of $291 \mathrm{MW}$ at full power for Cycles 9 through 12 (previously 400MW for Cycles 1 through 8).

Pin fission power can be calculated as

$$
\mathrm{PP}_{\mathrm{F}}=\mathrm{AP}_{\mathrm{F}} * \mathrm{R} / \mathrm{N}
$$

where

$$
\begin{aligned}
\mathrm{PP}_{\mathrm{F}}= & \text { pin fission power } \\
\mathrm{AP}_{\mathrm{F}}= & \text { assembly fission power } \\
\mathrm{N}= & \text { number of pins }=169 \\
\mathrm{R}= & \begin{array}{l}
\text { ratio of particular pin power to assembly average pin power = assembly map of radial } \\
\text { pin power distribution normalized to assembly average of } 1.0 .
\end{array}
\end{aligned}
$$

Pin deposited power can be calculated as

$$
\mathrm{PP}_{\mathrm{D}}=\mathrm{PP}_{\mathrm{F}} * \mathrm{D}
$$


where

$$
\begin{aligned}
& \mathrm{PP}_{\mathrm{D}}=\text { pin deposited power } \\
& \mathrm{D}=\text { ratio of power deposited in pin (fuel and cladding) to fission power generated in pin. }
\end{aligned}
$$

Power in each of the eighteen axial pin segments can then be obtained by multiplying the pin powers by the axial power profile (which has been normalized to an axial average of 1.0) and dividing by 18 .

The pin segment power can be converted to linear powers at specific axial elevations by dividing by the fuel segment height $(5.127 \mathrm{~cm}$ in the model $)$.

\subsubsection{Individual Pin Thermal Operating Conditions}

Normalized pin power distributions were calculated using the HEDPIN computer program based on interpolating the fission powers from the calculational mesh to the pin positions. The pin power distributions and subchannel coolant temperatures were used to determine fuel pin temperature and power profiles using the $\mathrm{SAFE}^{10}$ computer code.

Two pins were identified for detailed temperature and axial power distribution analysis and full non-destructive and destructive post-irradiation examination. The pins with serial number 193045 (a 4th row pin) from the MFF-3 assembly and serial number 195011 (a 4th row pin) from the MFF-5 assembly appeared to have experienced high power and hence high temperature operation, nearly peak for the assembly. Because of the orientation of the assemblies during their irradiation history, some of the 4th row pins tend to be the highest power pins and hence the highest temperature pins in the assembly over the life of the assembly. Figure 8 and Figure 9, provide a cycle-to-cycle history of the peak pin power and the peak inner cladding temperature for Pin 193045 from MFF-3, respectively. Figure 10 shows the axial linear power profile and axial temperature profiles for Pin 193045 from MFF-3.

Figure 11 and Figure 12 provide a cycle-to-cycle history of the peak pin power and the peak inner cladding temperature for Pin 195011 from MFF-5, respectively. Figure 13 shows the axial linear power profile and axial temperature profiles for Pin 195011 from MFF-5.

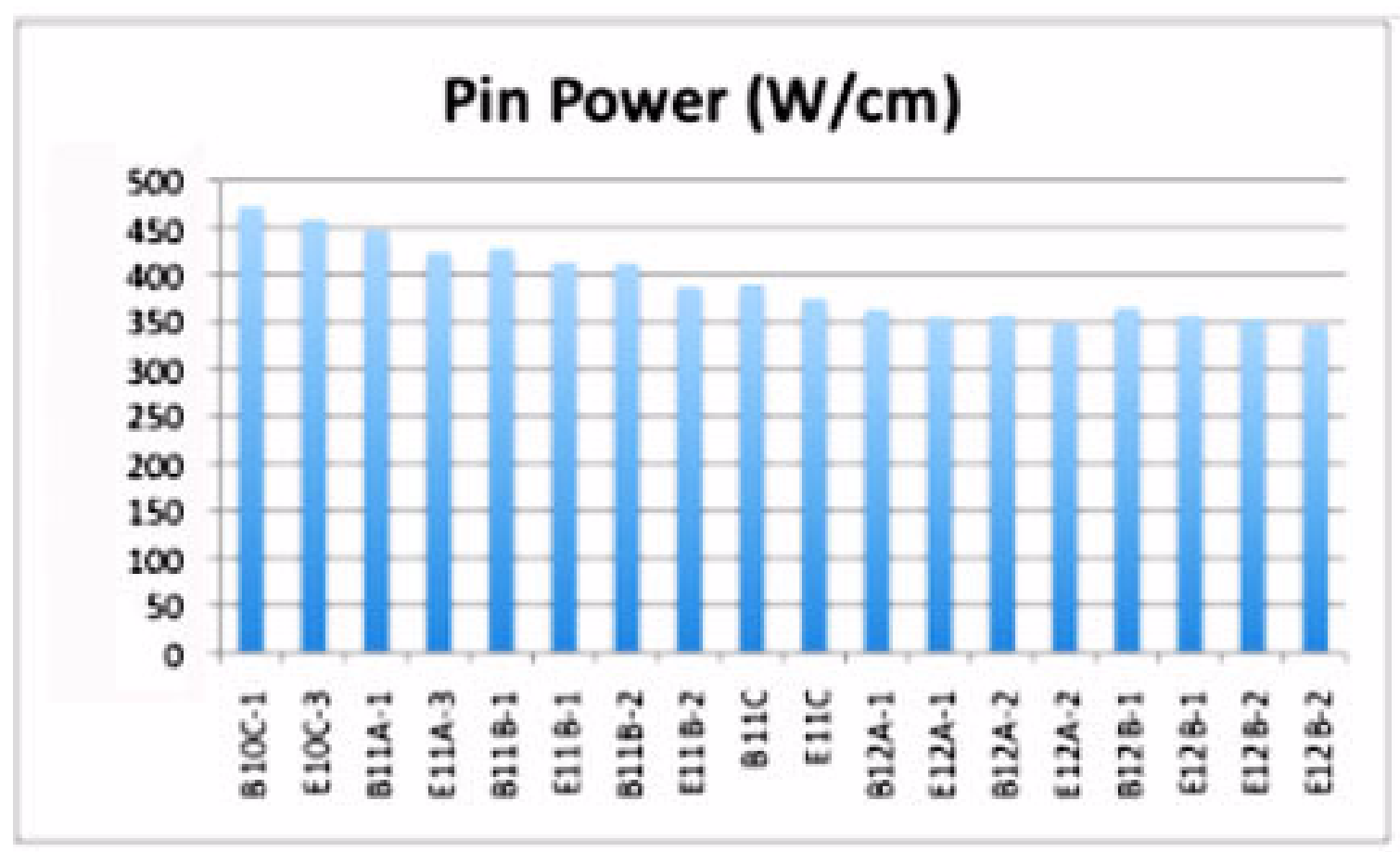

Figure 8. MFF-3, Pin Number 193045, pin power as a function of FFTF cycle number. 


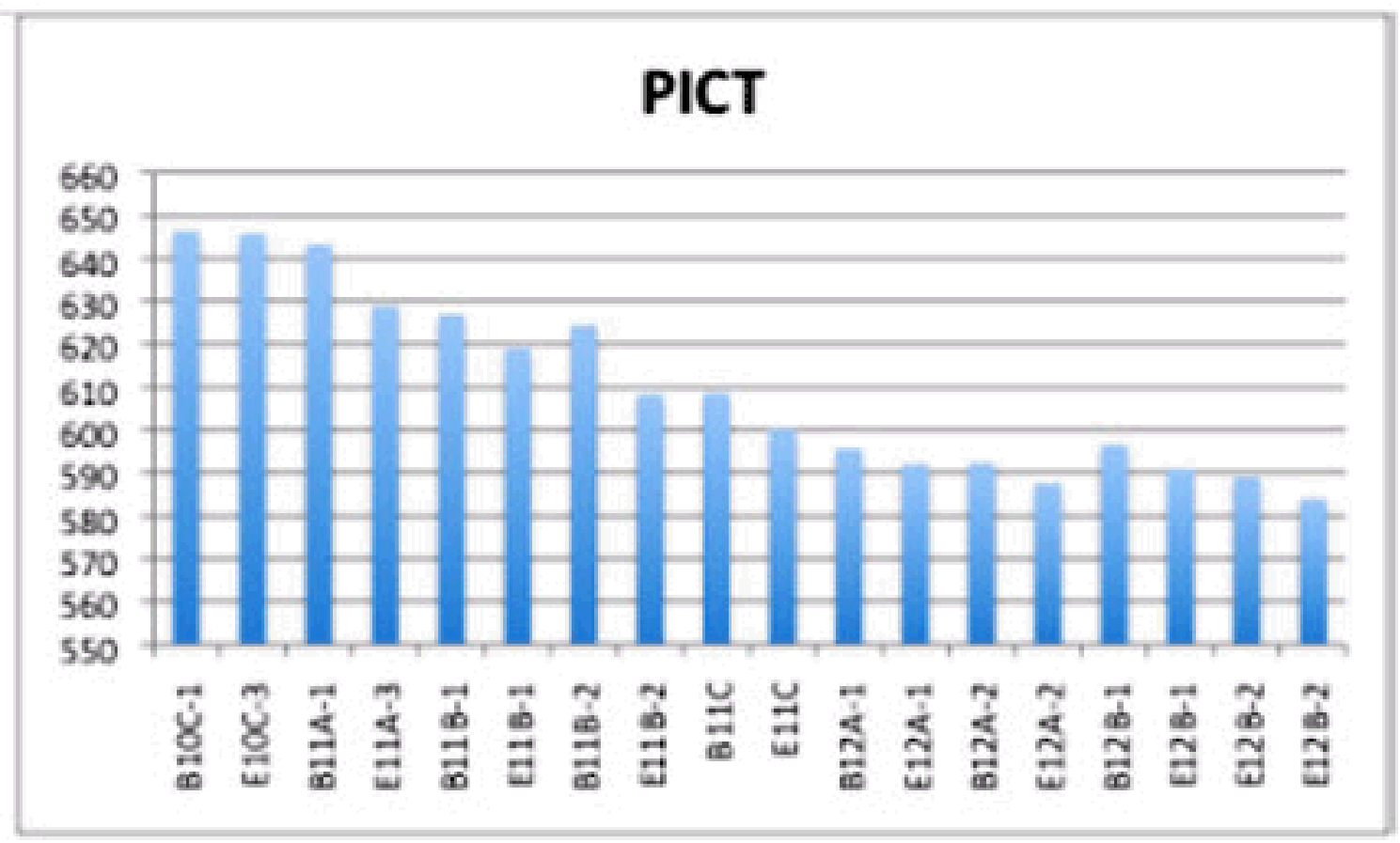

Figure 9. MFF-3, Pin Number 193045 peak inner cladding temperature, in ${ }^{\circ} \mathrm{C}$, as a function of FFTF cycle number.

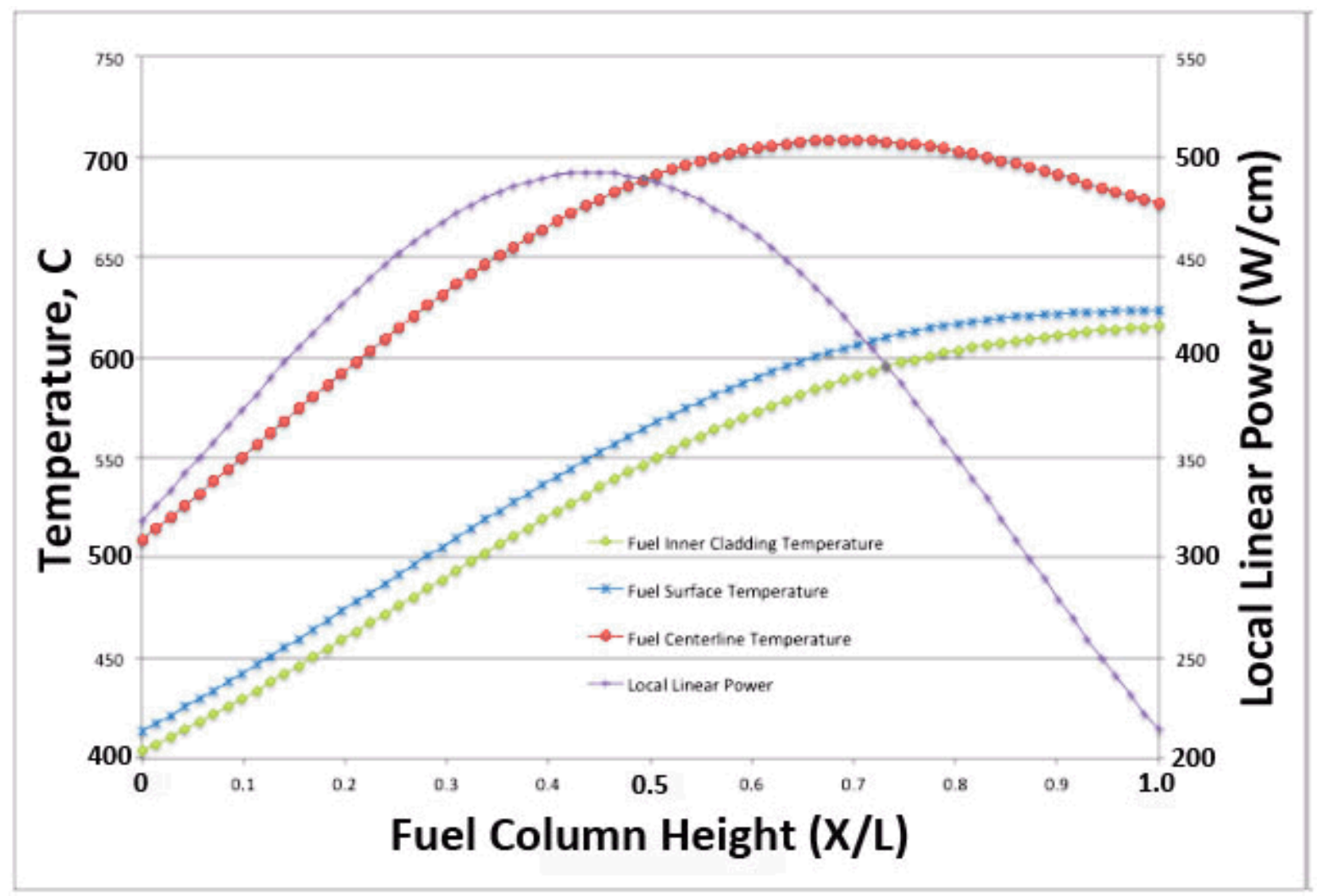

Figure 10. MFF-3, Pin Number 193045 inner cladding, fuel centerline and fuel surface temperatures, as well as pin power as a function of axial position on the pin. Values are averaged over the total EFPDs. 
Note that the fuel temperatures peak below the top of the fuel column as the pin power drops off, but the cladding temperature peaks at the top of the fuel column, influenced by the steady increase in the coolant temperature.

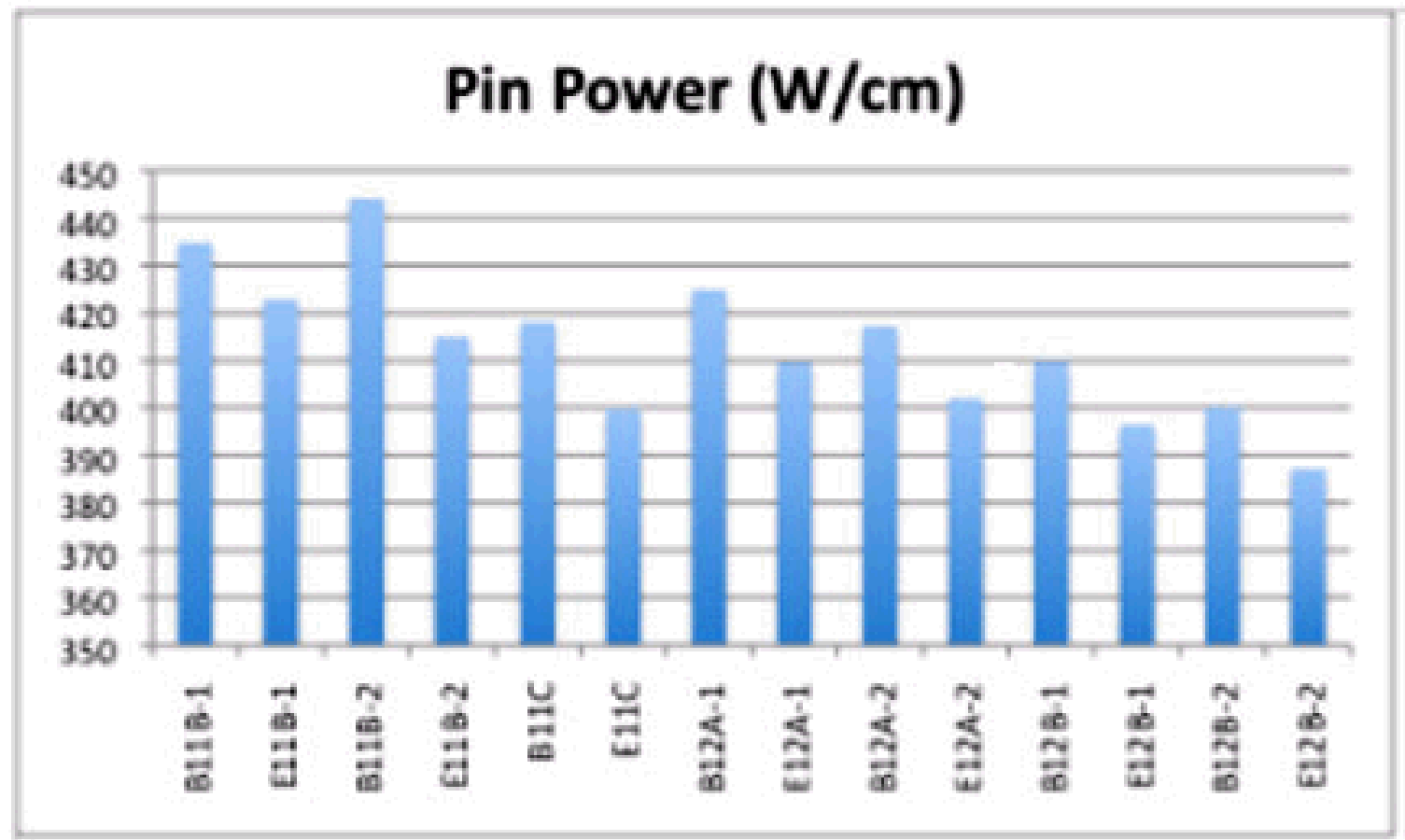

Figure 11. MFF-5, Pin Number 195011, pin power as a function of FFTF cycle number.

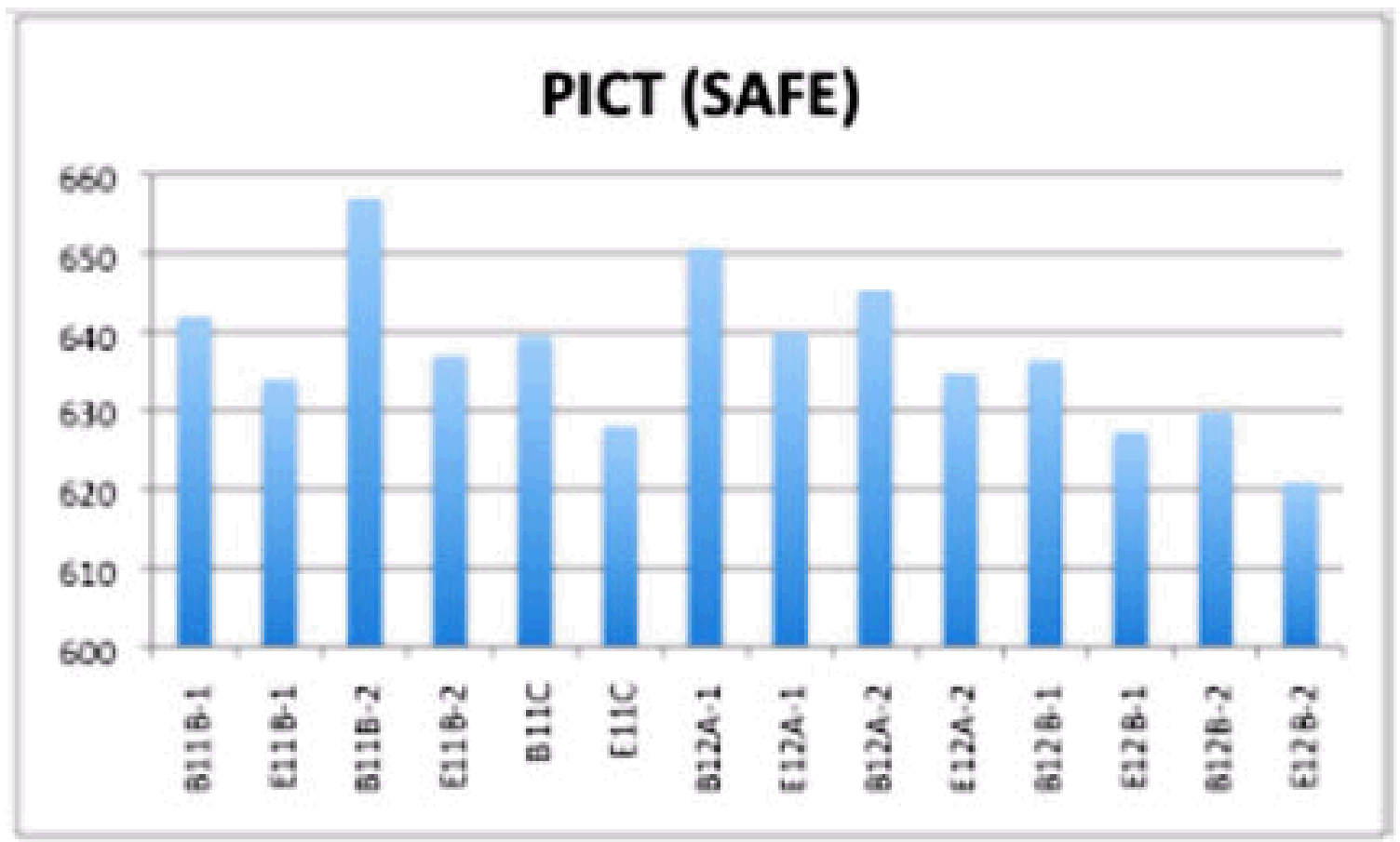

Figure 12. MFF-5, Pin Number 195011 peak inner cladding temperature, in ${ }^{\circ} \mathrm{C}$, as a function of FFTF cycle number. 


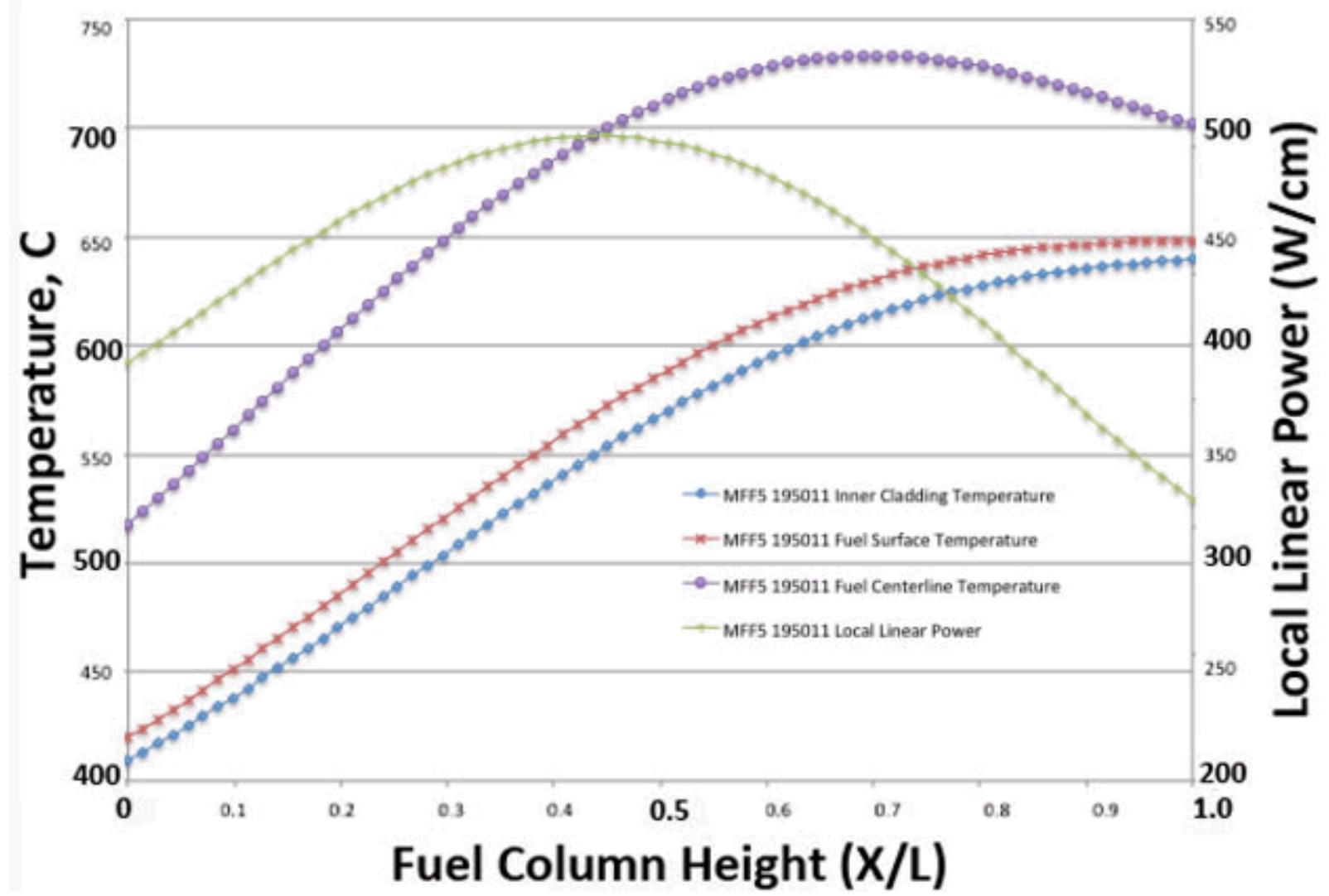

Figure 13. MFF-5, Pin Number 195011, inner cladding, fuel centerline and fuel surface temperatures, as well as pin power as a function of axial position on the pin. Values are averaged over the total EFPDs.

\subsubsection{ORIGEN Calculation}

Appendix A contains a large table, Table A-1(a-m), showing the results of ORIGEN-based composition calculations for a single pin, 195011,where isotopic fuel (heavy metal) and fission product compositions were calculated for every two-inch segment of the 36-inch fuel column. The compositions were calculated for both pins that were destructively characterized, one from MFF-3 and one from MFF-5. These results are used subsequently in this report to compare burnup/depletion calculations with analytical chemistry measurements. The compositions were also useful in computing the expected radiation fields around samples from the fuel pins, allowing work to be planned to minimize personnel exposures.

\section{POST-IRRADIATION EXAMINATIONS}

Table 4 shows the MFF-3 and MFF-5 pin numbers and the examinations performed on each of them. The table shows which pins were examined by neutron radiography, visual, precision gamma scanning, bow and length measurements, element spiral contact profilometry (ESP), element linear contact profilometry (ECP), plenum gas chemical analysis and pressure measurements (GASR), metallography and microhardness.

Table 4. Post-irradiation examination listing.

\begin{tabular}{|c|c|c|c|c|c|c|c|c|}
\hline $\begin{array}{c}\text { Assembly: } \\
\text { Fuel Pin Number }\end{array}$ & \multicolumn{7}{|c|}{ Examinations } \\
\cline { 2 - 8 } & $\begin{array}{c}\text { Neutron } \\
\text { Radiography }\end{array}$ & Visual & $\begin{array}{c}\text { Gamma } \\
\text { Scans }\end{array}$ & ECP & ESP & GASR & $\begin{array}{c}\text { Burnup } \\
\text { Analysis }\end{array}$ & Metallography \\
\hline
\end{tabular}




\begin{tabular}{|l|c|c|c|c|c|c|c|c|}
\hline MFF-3: 193020 & $\mathrm{X}$ & $\mathrm{X}$ & $\mathrm{X}$ & & $\mathrm{X}$ & & & \\
\hline MFF-3: 193025 & $\mathrm{X}$ & $\mathrm{X}$ & $\mathrm{X}$ & & $\mathrm{X}$ & & & \\
\hline MFF-3: 193045 & $\mathrm{X}$ & $\mathrm{X}$ & $\mathrm{X}$ & $\mathrm{X}$ & & $\mathrm{X}$ & $\mathrm{X}$ & $\mathrm{X}$ \\
\hline MFF-3: 193062 & $\mathrm{X}$ & $\mathrm{X}$ & $\mathrm{X}$ & & $\mathrm{X}$ & & & \\
\hline \multicolumn{7}{|l|}{} \\
\hline MFF-5: 195011 & $\mathrm{X}$ & $\mathrm{X}$ & $\mathrm{X}$ & $\mathrm{X}$ & & $\mathrm{X}$ & $\mathrm{X}$ & $\mathrm{X}$ \\
\hline MFF-5: 195012 & $\mathrm{X}$ & $\mathrm{X}$ & $\mathrm{X}$ & & $\mathrm{X}$ & & & \\
\hline MFF-5: 195051 & $\mathrm{X}$ & $\mathrm{X}$ & $\mathrm{X}$ & & $\mathrm{X}$ & & & \\
\hline MFF-5: 195052 & $\mathrm{X}$ & $\mathrm{X}$ & $\mathrm{X}$ & & $\mathrm{X}$ & & & \\
\hline
\end{tabular}

\subsection{Neutron Radiography}

Four irradiated metallic fuel pins in each of MFF-3 and MFF-5 were radiographed using indium foil neutron detectors (epithermal neutrons) and dysprosium foil detectors (thermal neutrons). The activated foils were then used to transfer images to film. The films were $\sim 43 \mathrm{~cm}$ long requiring six shots to cover the entire pin length of $240 \mathrm{~cm}$.

The epithermal neutrons provide for weaker contrast because of the neutrons being of higher energy, but do allow greater penetration of the fuel. Appendix B shows the pins that received detailed examinations (highlighted in Table 4). Note that the images shown in Appendix B have been 'stitched together' from the component radiographs over the length of the pin. The larger digitized radiograph files have been archived as have the original radiographs/films. Also note that there is a slight 'double image' created by aperture misalignment in the neutron beam port.

The spacer wires can be seen in the images, shown wrapped around the cladding in all but the images of 193045 and 195011, the pins that were eventually destructively examined. The wires had been removed to allow these destructive exams.

The axial growth of the fuel slugs was measured using the neutron radiography as shown in Figure 14. A precision graduated (to 0.02 inches or $0.51 \mathrm{~mm}$ ) scale was placed next to the fuel during radiography and used to measure the fuel column length. The relative fuel column length changes are indicated and are compared to a representative radiograph from $\mathrm{U}-10 \mathrm{Zr}$ fuel previously irradiated in FFTF, in assembly IFR-1. Note that the fuel in IFR-1 showed significantly greater axial growth. The IFR-1 data is much more similar to the experience gathered through EBR-II testing. ${ }^{11}$ The IFR-1 peak cladding temperature $(\mathrm{BOL})$ was $610^{\circ} \mathrm{C}$ 


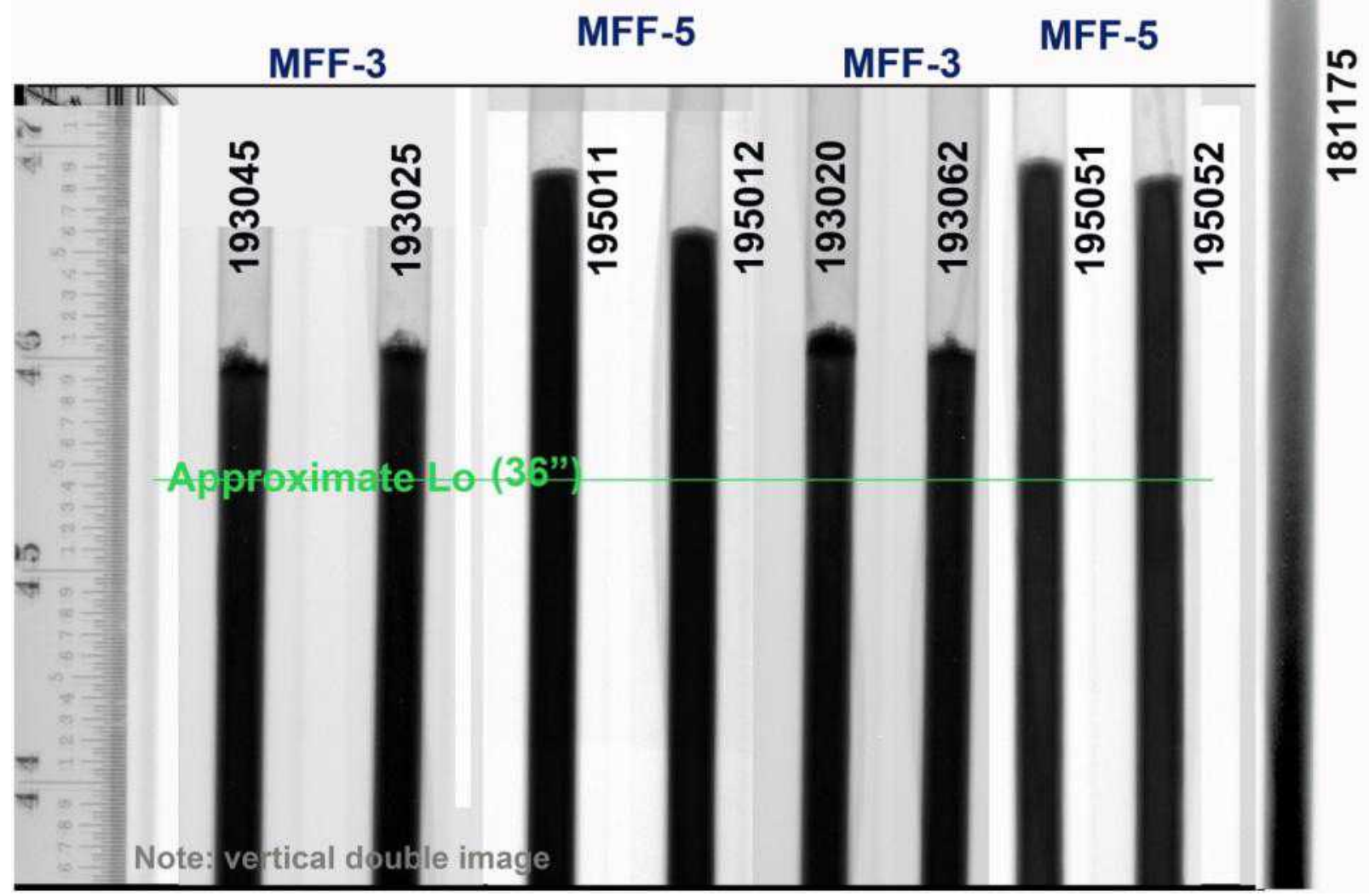

Figure 14. Neutron radiography of the tops of the fuel columns of two MFF-3 and two MFF-5 pins, showing the low axial growth compared to a typical IFR-1 pin $(36 \mathrm{in} .=91.4 \mathrm{~cm}$, the initial fuel column length).

The measured fuel growth is shown in Table 5; the as-fabricated lengths are assumed from the specification $(91.44 \mathrm{~cm})$ as none were measured prior to irradiation. Note that the axial growth is much less than expected from other testing.

The axial fuel column growth due to swelling is an important measurement in that most all of the other data related to the 33.4-cm fuel column length of EBR-II experimental pins. There was a question as to whether cladding contact due to radial swelling would then restrain further axial growth. In addition, the aspect ratio is much larger for the FFTF fuel, creating more axial stress from the weight of the slug at the bottom of the fuel column. The fact that the IFR-1 was only slightly less than EBR-II testing data, however, indicates that there is another factor involved in creating these low axial growth observations. One theory is that the very high fuel temperatures, combined with the long fuel column/large aspect ratio, creates the low axial growth as fuel creep forces material to flow in the opposite direction to the growth. Note, however that the axial growth in the EBR-II test X447, where the fuel operated as hot as the fuel operated in the MFF-3 and MFF-5 tests, the expansion was 5-9 \% with an average of $7 \%$, much like the colder IFR-1 test. ${ }^{12}$

Table 5. Axial growth of active fuel column as determined by neutron radiography.

\begin{tabular}{|c|c|c|c|c|c|c|c|c|}
\cline { 2 - 8 } \multicolumn{1}{c|}{} & \multicolumn{4}{c|}{ MFF-3 } & \multicolumn{4}{c|}{ MFF-5 } \\
\hline Pin No. & 193045 & 193025 & 193020 & 193062 & 195011 & 195012 & 195051 & 195052 \\
\hline
\end{tabular}




\begin{tabular}{|l|l|l|l|l|l|l|l|l|}
\hline$\Delta \mathrm{L} / \mathrm{L}_{0}, \%$ & 1.5 & 1.6 & 1.8 & 1.6 & 3.7 & 3.0 & 3.9 & 3.8 \\
\hline Avg., $\%$ & \multicolumn{9}{|c|}{1.6} & \multicolumn{6}{|c|}{3.6} \\
\hline
\end{tabular}

FFTF assemblies were each monitored for outlet temperature. As mentioned previously, it was noted that the assembly outlet temperature of the MFF-2 assembly was exhibiting a decline in outlet temperature that was larger than could be explained by depletion of fissile material content. 9 A graphical representation of this is shown in Figure $15 .{ }^{13}$ A similar phenomenon was seen in the outlet temperatures of the IFR-1 assembly.

Recall that Figure 4 and Figure 5 did not show an underprediction of the outlet temperature decline. This may be because the axial fuel growth was so small; the expansion of the fuel column of the U-10Zr fuel in the IFR-1 assembly was $\sim 7 \%$, at least twice that of MFF-3 and MFF-5.3. The MFF-2 axial expansion is to be measured to test this theory.

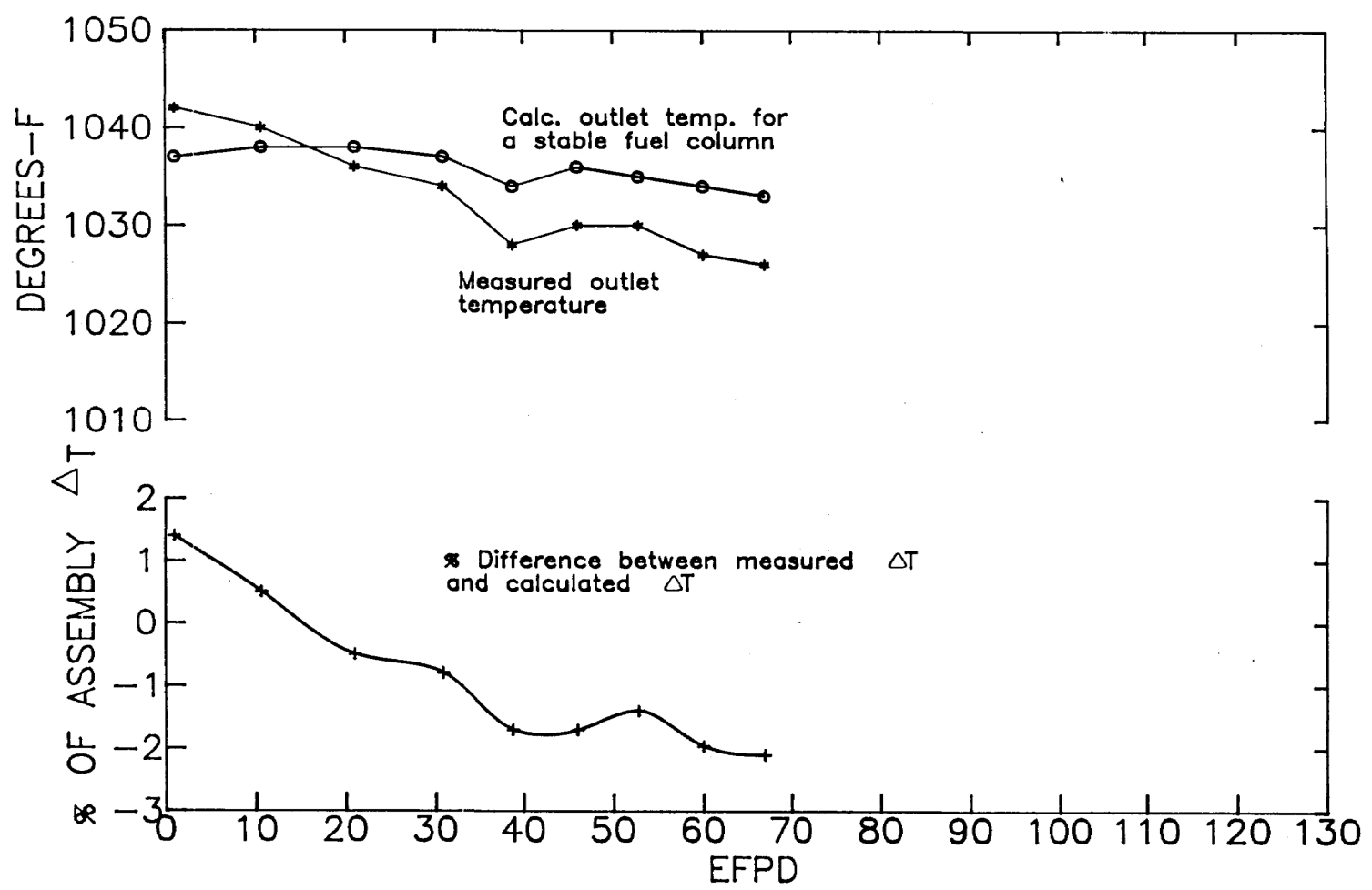

Figure 15. Assembly MFF-2 outlet temperatures; cycle 10B (from Ref. 13).

\subsection{Gamma Scanning}

Eight pins, four from MFF-3 and four from MFF-5, were scanned axially for gamma radiation. Parameters used were a slit width of $2.54 \mathrm{~mm}$, step size of $2.54 \mathrm{~mm}$ and a live time of 240s. The isotopes scanned were Cs-134, Co-60 and Eu-154. These were the only long-lived fission and activation products which could reliably be scanned. The Co-60 marks the stainless steel (HT-9) hardware locations, the Cs-134 represents the very mobile fission products, and the Eu-154 was the only rare earth fission product remaining which could be scanned. There were no relatively immobile fission products remaining to assess were the fuel was located. The gross activity (all isotopes) was also recorded.

Figure 16 and Figure 17 show typical gamma scan traces for an MFF-3 pin (193045) and an MFF-5 pin (195011) respectively. The Co-60 traces show where the activated stainless steel (HT-9) from the fuel 
jacket and end plugs are located and especially the Inconel reflector. The Cs-134 is peaked in the typical region just above the fuel where Cs gets trapped in the bond sodium that forms a molten plug above the fuel column. Some of these plugs can be forced by build-up of fission gas upwards in the plenum although there are no obvious spikes in Cs shown here.

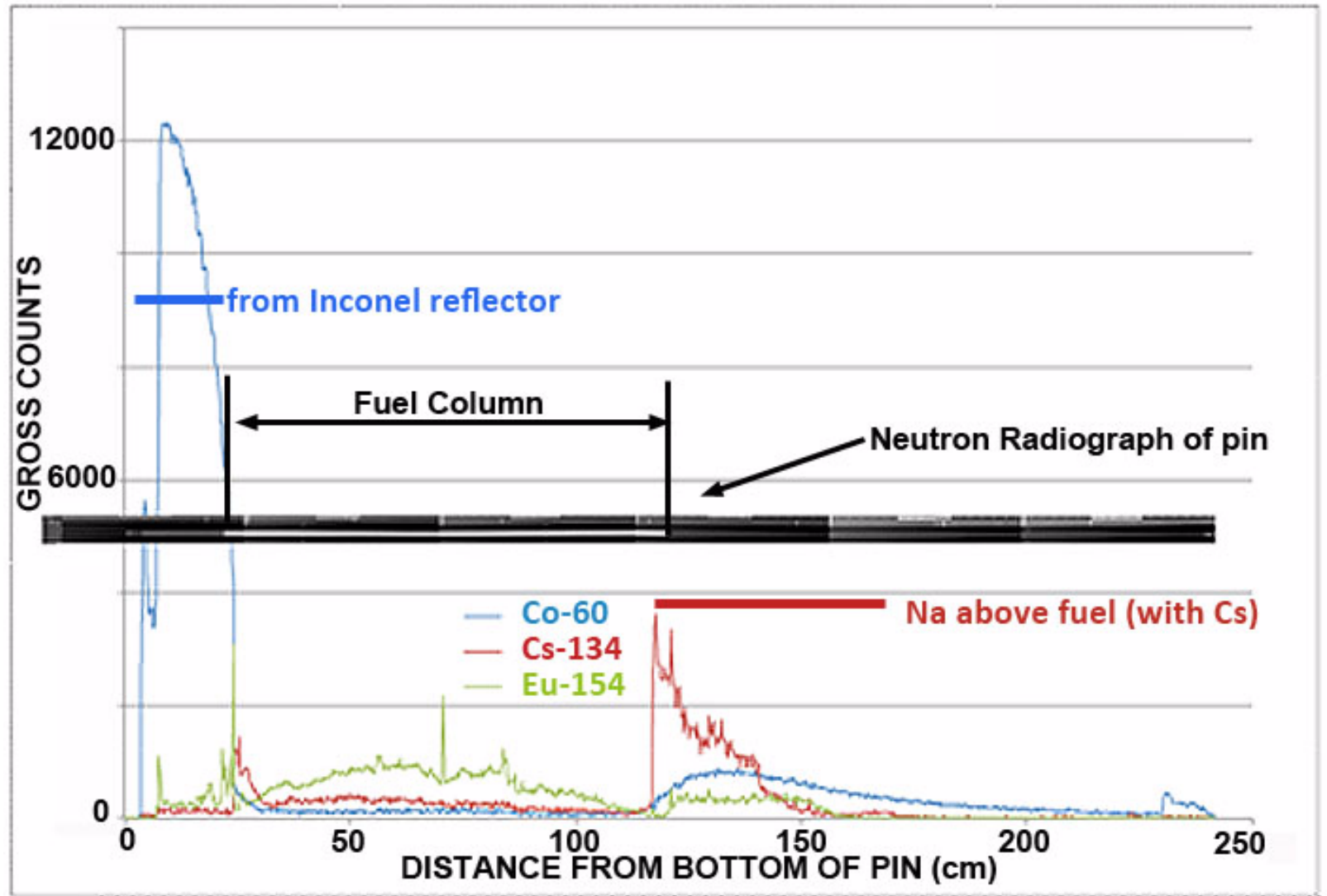

Figure 16. Gamma scan traces for Pin 193045 from MFF-3. Neutron radiograph is superimposed. 


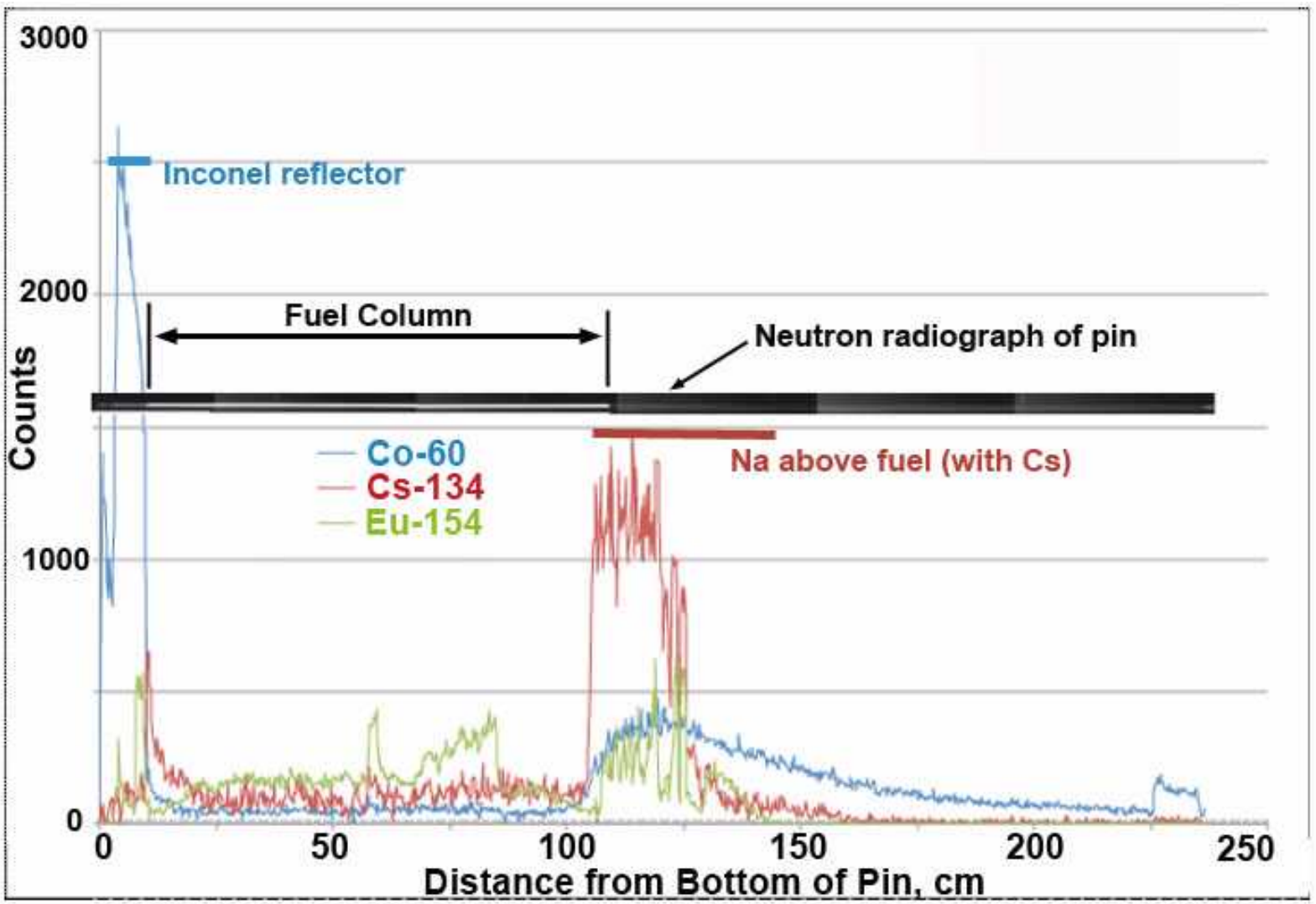

Figure 17. Gamma scan traces for Pin 195011 from MFF-5. Neutron radiograph is superimposed.

All of the gamma scan results are plotted in figures in Appendix C.

\subsection{Bow and Length}

The bow-and-length measurement maps the free-hanging position of the fuel rod tangent along the axial length of the specimen. The element bow and length machine (EBLM) has two orthogonal bars, each holding a light source and photo detector. The bars traverse a $12 \times 12$-in. area in the X-Y plane, centered on the system examination center. The bow data is reported as coordinates on a two-dimensional grid at discreet axial positions, and total length is determined by summing the individual chord lengths. Figure 18 shows the coordinate reference frame used to record measurements for bow and length. The complete set of data has been archived but is not presented here.

The length measurement uncertainty is $\pm 381 \mu \mathrm{m}$ (0.015 in.). The bow uncertainty is $\pm 510 \mu \mathrm{m}$ ( 0.020 in.) The uncertainty of the azimuthal orientation is $\pm 3.0^{\circ}$, and the uncertainty of axial position is $\pm 250 \mu \mathrm{m}(0.010$ in.). 


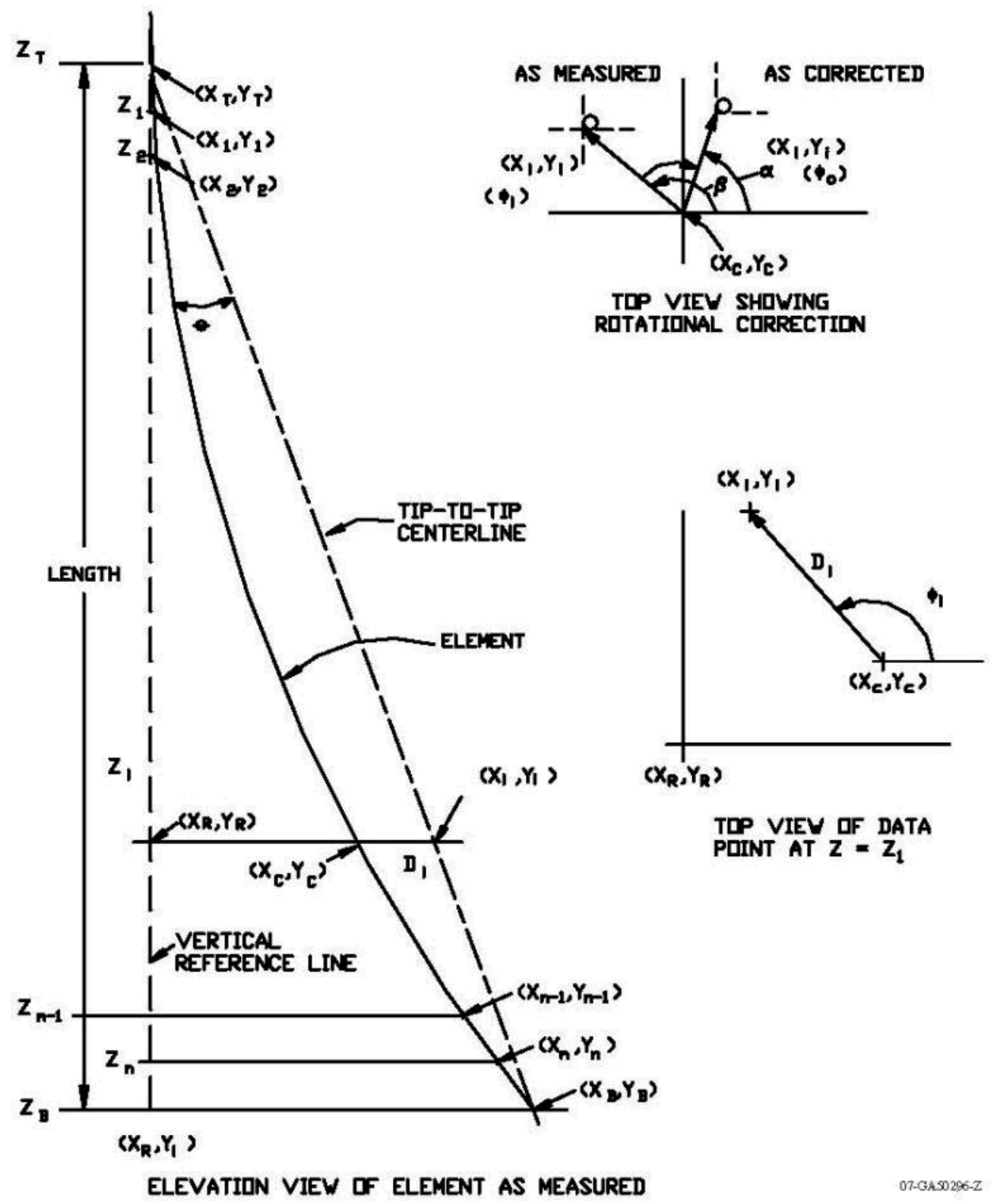

Figure 18. Sketch for the reference frame and measurement coordinates used to record bow and length data.

The pin length was measured two ways. The first was directly noting the $\mathrm{Z}$ travel during profilometry, called 'hanging length', shown as 'LENGTH' in the drawing. Secondly, the true length is extracted from the Z-data along with the bow coordinate data. The results are shown in Table 6.

Table 6. 'Hanging' lengths of pins before and after irradiation. 


\begin{tabular}{|cccc|}
\hline Pin & As-built Length, cm & Hanging Length, cm & Growth, cm \\
\hline 193025 & 238.11 & 238.57 & 0.46 \\
193025 & 238.11 & 238.59 & 0.48 \\
\hline 193020 & 238.11 & 238.68 & 0.57 \\
\hline 193062 & 238.12 & 239.18 & 1.06 \\
193062 & 238.12 & 239.27 & 1.15 \\
\hline 195051 & 237.11 & 237.86 & 0.75 \\
\hline 195012 & 237.11 & 237.60 & 0.49 \\
195012 & 237.11 & 237.60 & 0.49 \\
\hline 195052 & 237.11 & 238.03 & 0.92 \\
195052 & 237.11 & 238.03 & 0.92 \\
\hline
\end{tabular}

\subsection{Element Spiral Contact Profilometer (ESP)}

The diameter profiles for six pins (three MFF-3, three MFF-5) were measured using spiral profilometry, measuring the pin diameter as a function of pin elevation. This allowed the diameter measurements without removal of the spacer wire. The results are shown in Figure 19 through Figure 24.

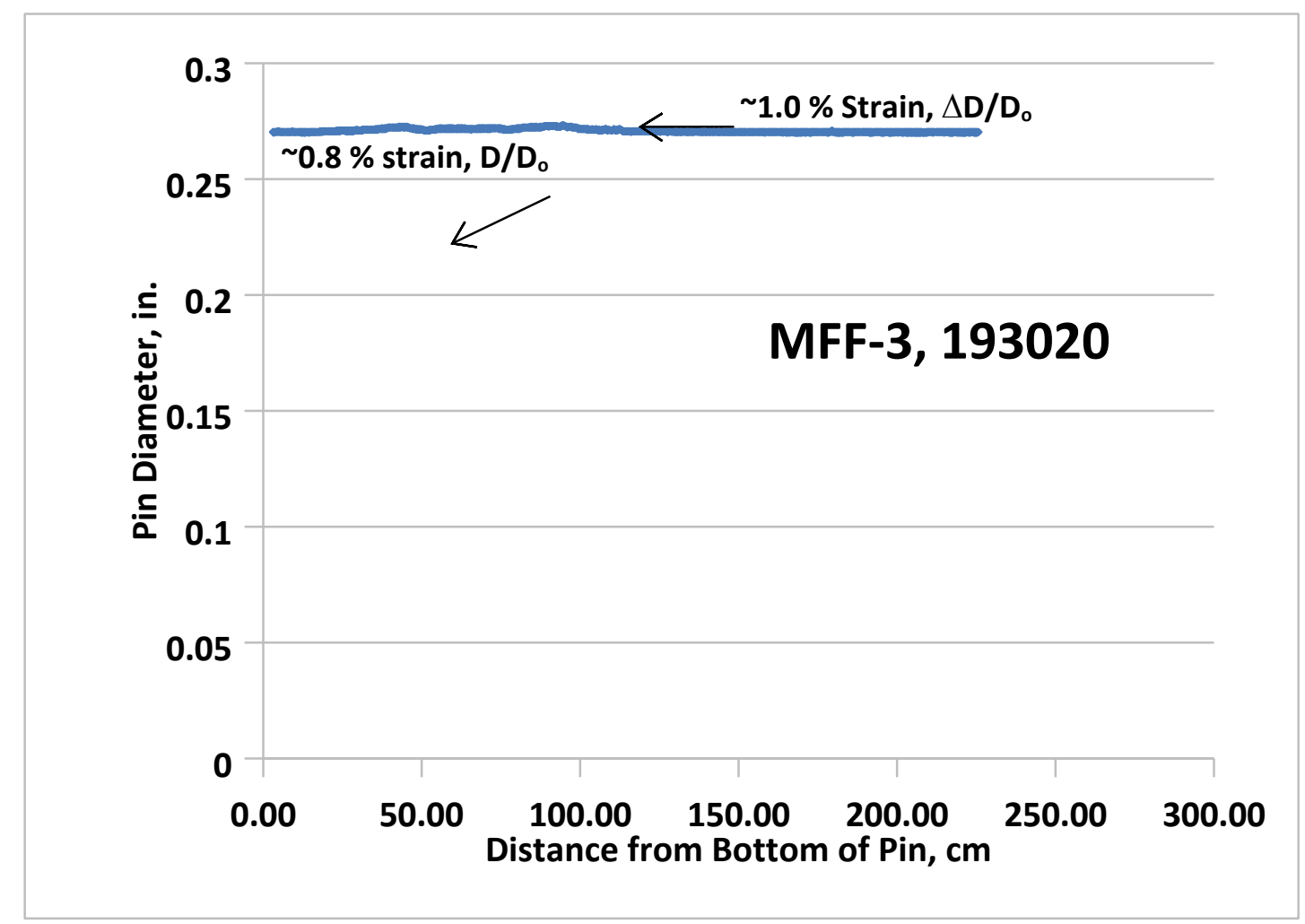

Figure 19. Spiral contact profilometry for MFF-3 Pin 193020. 


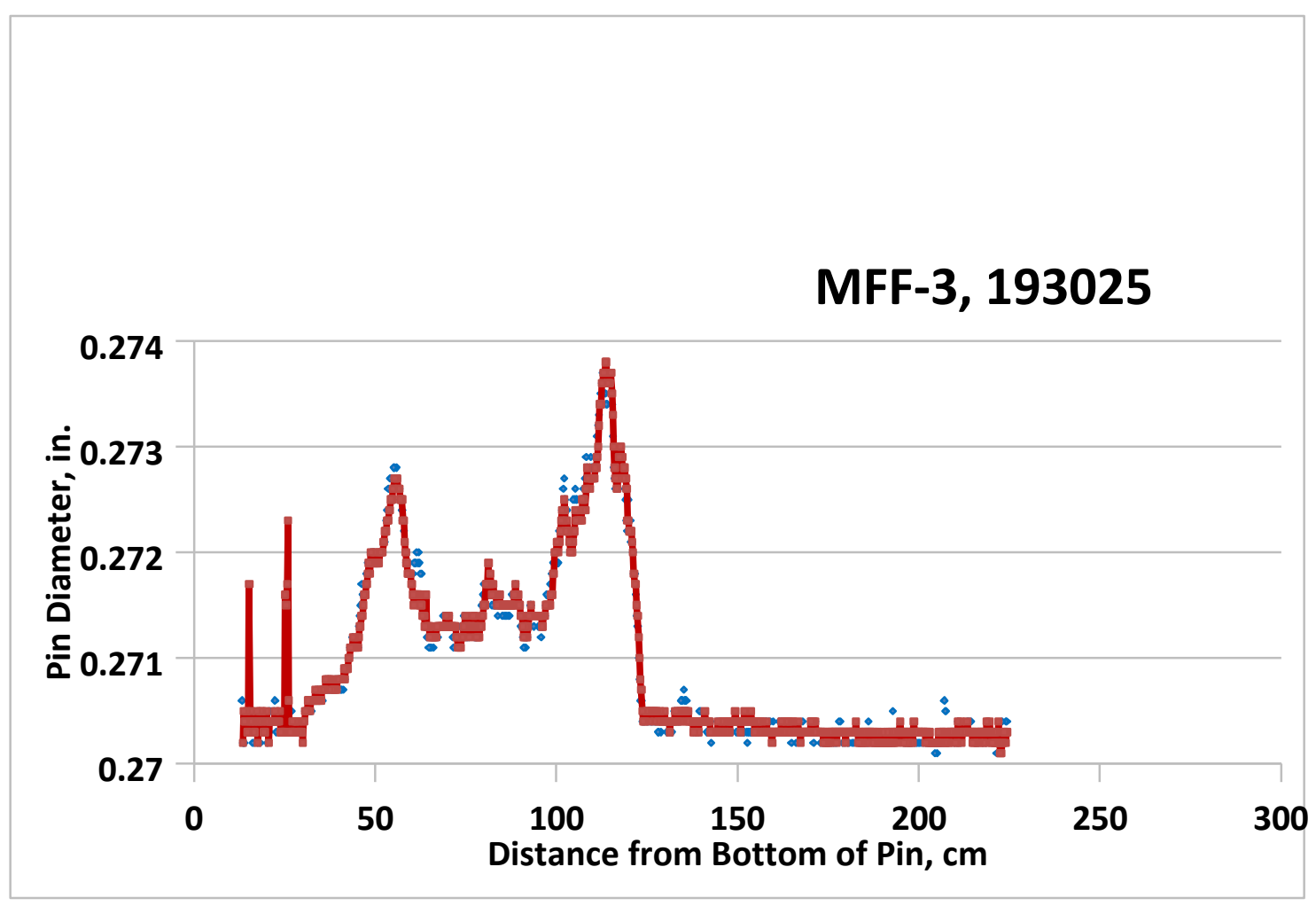

Figure 20. Spiral contact profilometry for MFF-3 Pin 193025.

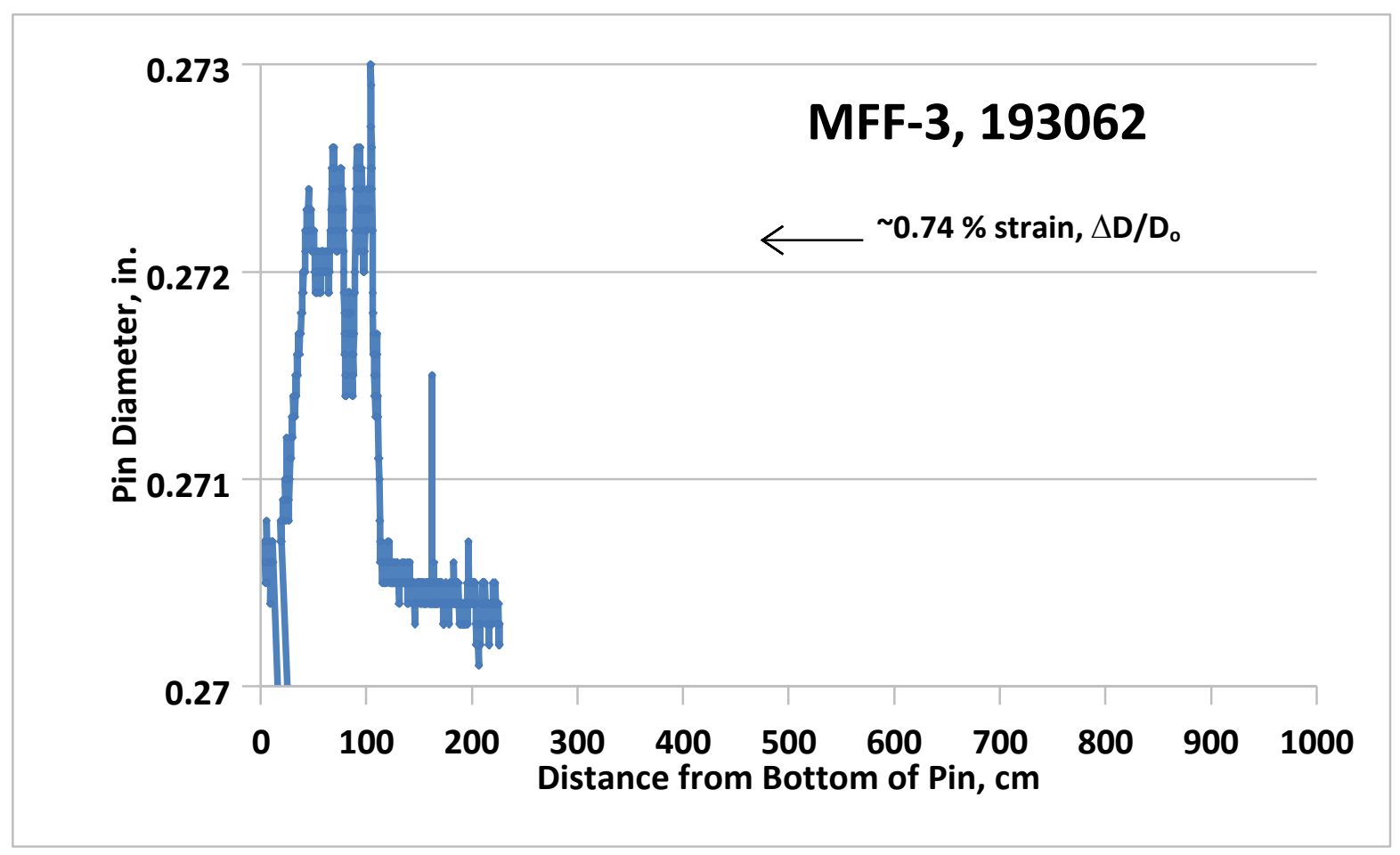

Figure 21. Spiral contact profilometry for MFF-3 Pin 193062. 


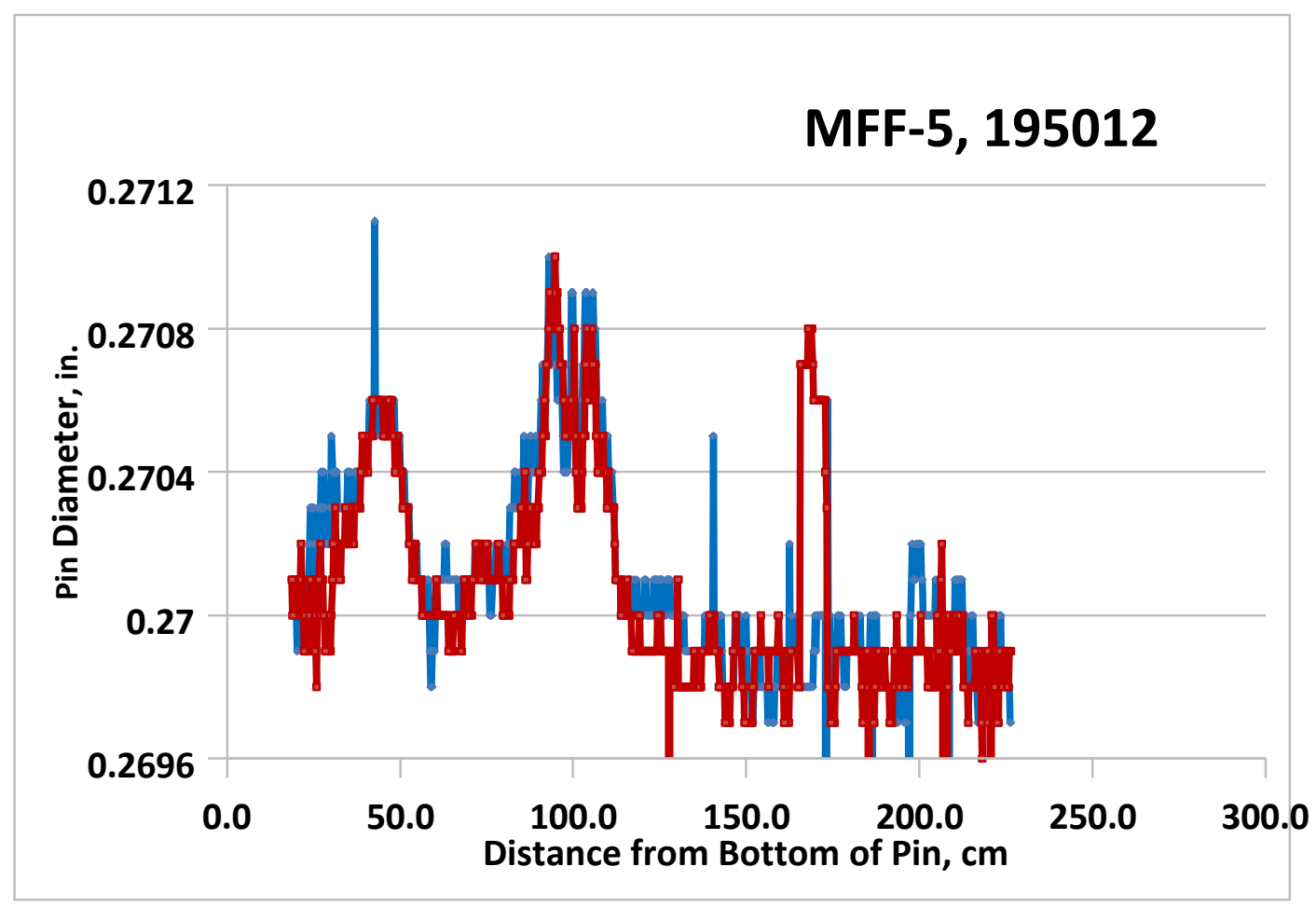

Figure 22. Spiral contact profilometry for MFF-5 Pin 195012.

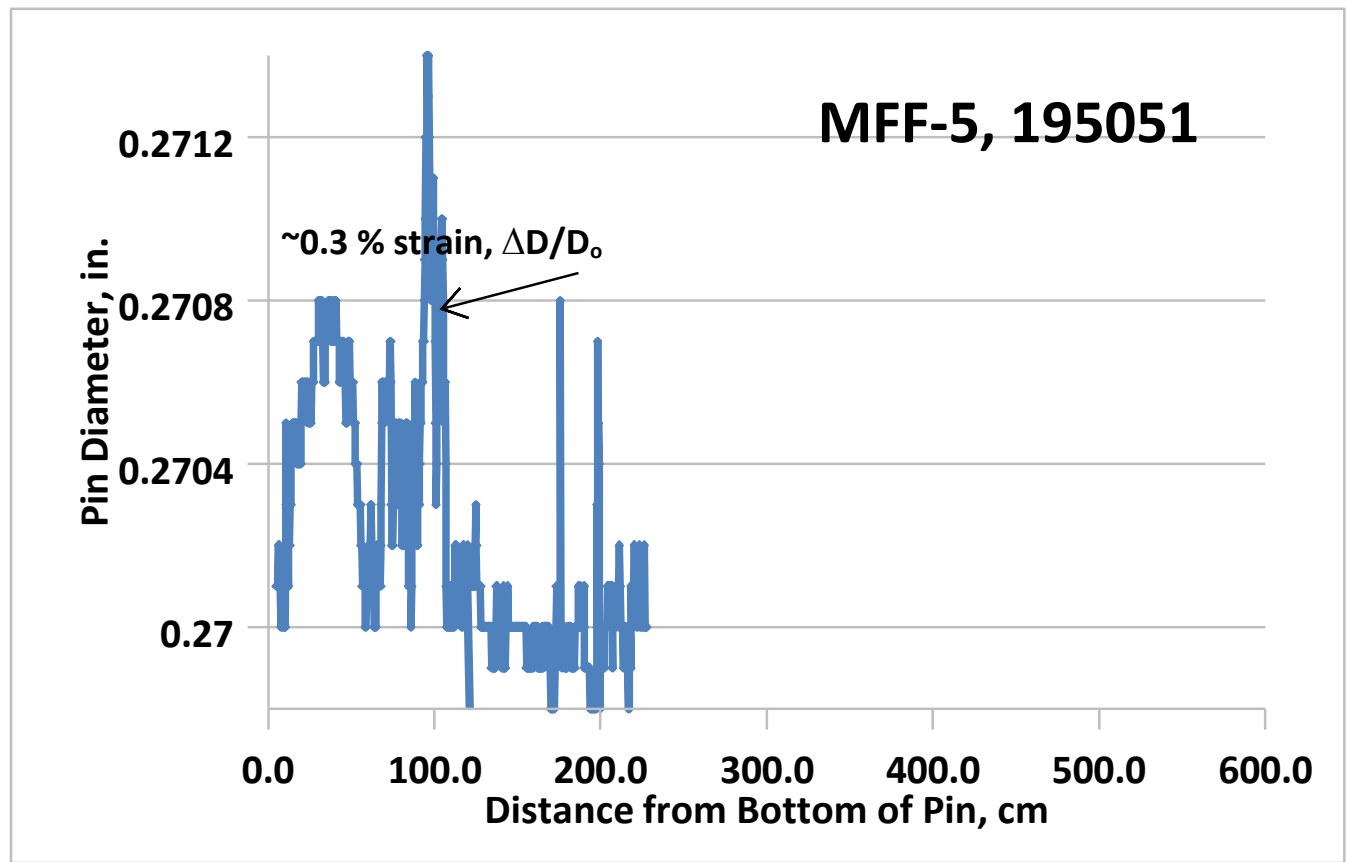

Figure 23. Spiral contact profilometry for MFF-5 Pin 195051. 


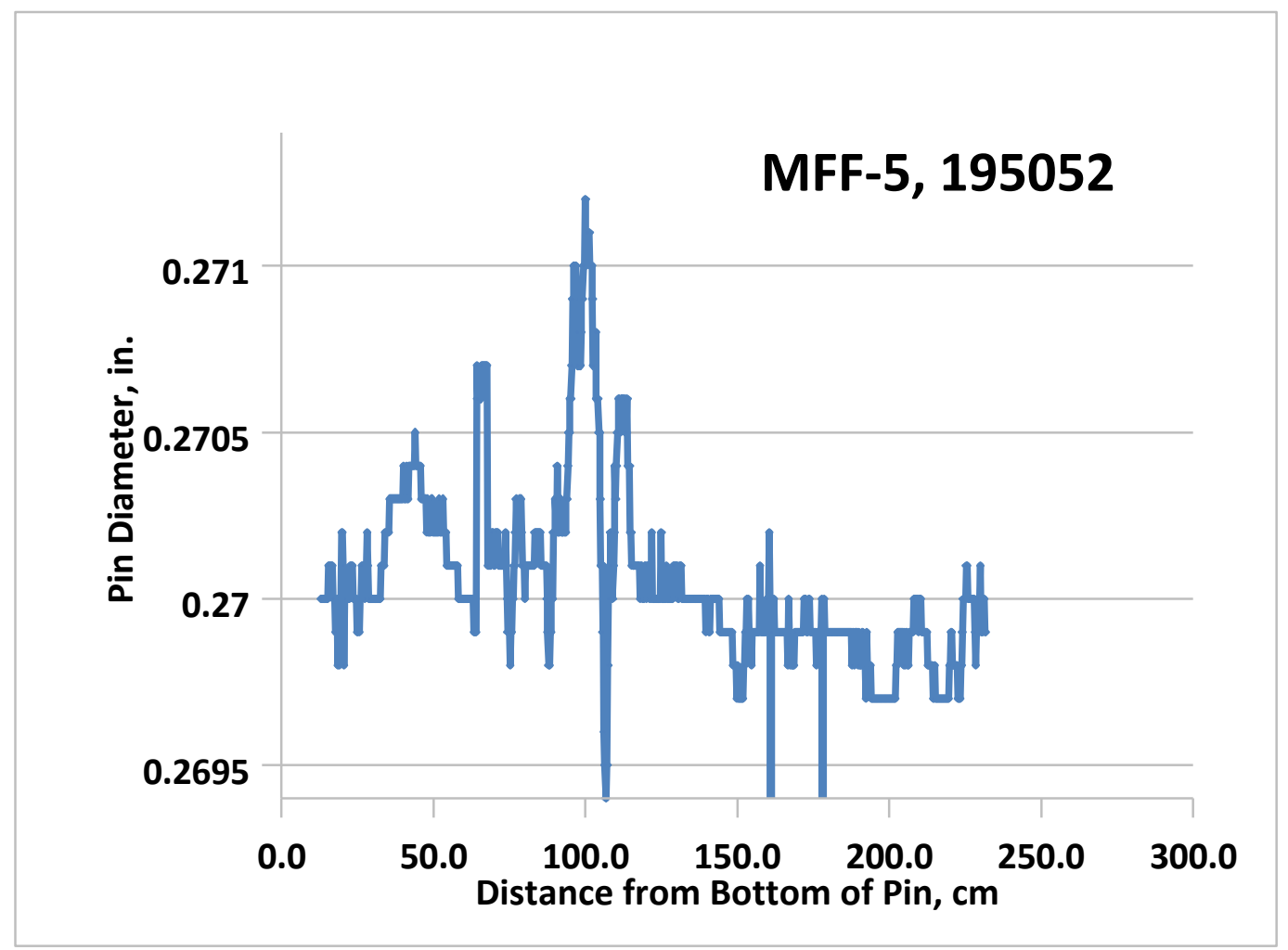

Figure 24. Spiral contact profilometry for MFF-5 Pin 195052.

\subsection{Element Linear Contact Profilometer (ECP)}

The two pins that were to be destructively examined were examined using linear contact profilometry where the pin diameter is measured as a function of axial position. The wire wrap is removed and the pin diameter is recorded as a function of elevation at a constant circumferential location. The pin is then rotated and a profile recorded every $45^{\circ}$ until the pin has been rotated $135^{\circ}$. This allows interpretation of bulges to one side, detection of ovality and even relative direction of ovality, showing approximate locations of minor and major elliptical axes.

The scans were taken $\sim 13 \mathrm{~cm}$ from the bottom of the pin to $\sim 4 \mathrm{~cm}$ from the top. The $13-\mathrm{cm}$ location will be used in the graphical representations of the data as the ' 0 ' elevation.

NOTE: For MFF-3, the bottom end plug is $3.4 \mathrm{~cm}$ from its tip to where it joins the cladding; the end plug insert into the cladding is $0.64 \mathrm{~cm}$ long; the internal axial reflector is $16.5 \mathrm{~cm}$ long. For $M F F-5$, the bottom end plug is $2.9 \mathrm{~cm}$ from its tip to where it joins the cladding; the end plug insert into the cladding is $0.64 \mathrm{~cm}$ long; the internal axial reflector is $6.4 \mathrm{~cm}$. So, the bottom of the fuel column starts at $7 \mathrm{~cm}$ on the MFF-3, $193045 \mathrm{graph}$, and at $-3.1 \mathrm{~cm}$ on the MFF-5, 195011 graph.

Figure 25 and Figure 26 show the linear contact profilometry traces for Pins 193015 (MFF-3) and 195011 (MFF-5), respectively. As stated above the ' 0 ' position is actually $1.5 \mathrm{~cm}$ from the base of the pin. The entire scans are not shown as the plenum shows little or no strain.

The MFF-3 pin shows peak strain of 1.2-1.3\% with a 'double peak' behavior, one peak occurring near core midplane (highest neutron fluence) and one nearing the top of the fuel column (peak cladding temperature). These perhaps represent peaks in irradiation-induced creep and thermal creep. Figure 26 shows that the MFF-5 pin has only about one-third of the diameter strain that the MFF-3 pin demonstrated, the centerline strain even less than that. 
Regular undulations are usually an indication of an elliptical cross section. This is sometimes due to handling and sometimes created when the pins expand together and contact along a pinch point where the wire wraps align along a grid, and the cladding is compressed, forming the minor axis of the ellipse on the cladding cross section, usually at places of maximum strain. At $90^{\circ}$ the bulge corresponding to the major axis of the ellipse is developed. Therefore, the peaks and valleys align for those $90^{\circ}$ apart, and valleys and peaks are aligned. See for example in Figure 25 the red $\left(45^{\circ}\right)$ and green $\left(135^{\circ}\right)$ at $\sim 45 \mathrm{~cm}$ elevation. Another place of potential elliptical shape is just into the plenum at $\sim 110 \mathrm{~cm}$ elevation.

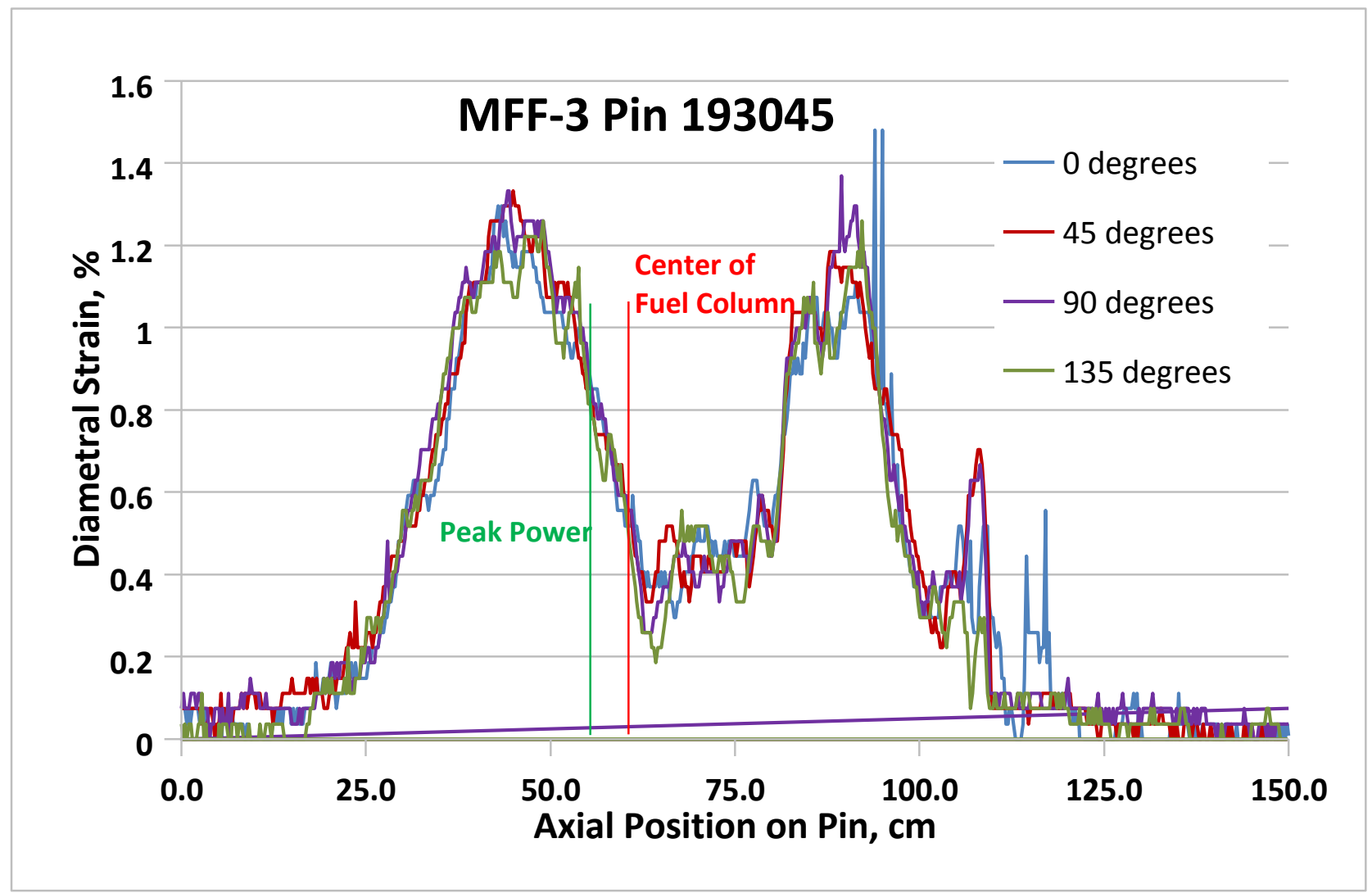

Figure 25. Linear contact profilometry of Pin 193045. Four scans shown as pin is rotated $45^{\circ}$ between scans. Much of the plenum is not shown to emphasize the fuel column. 


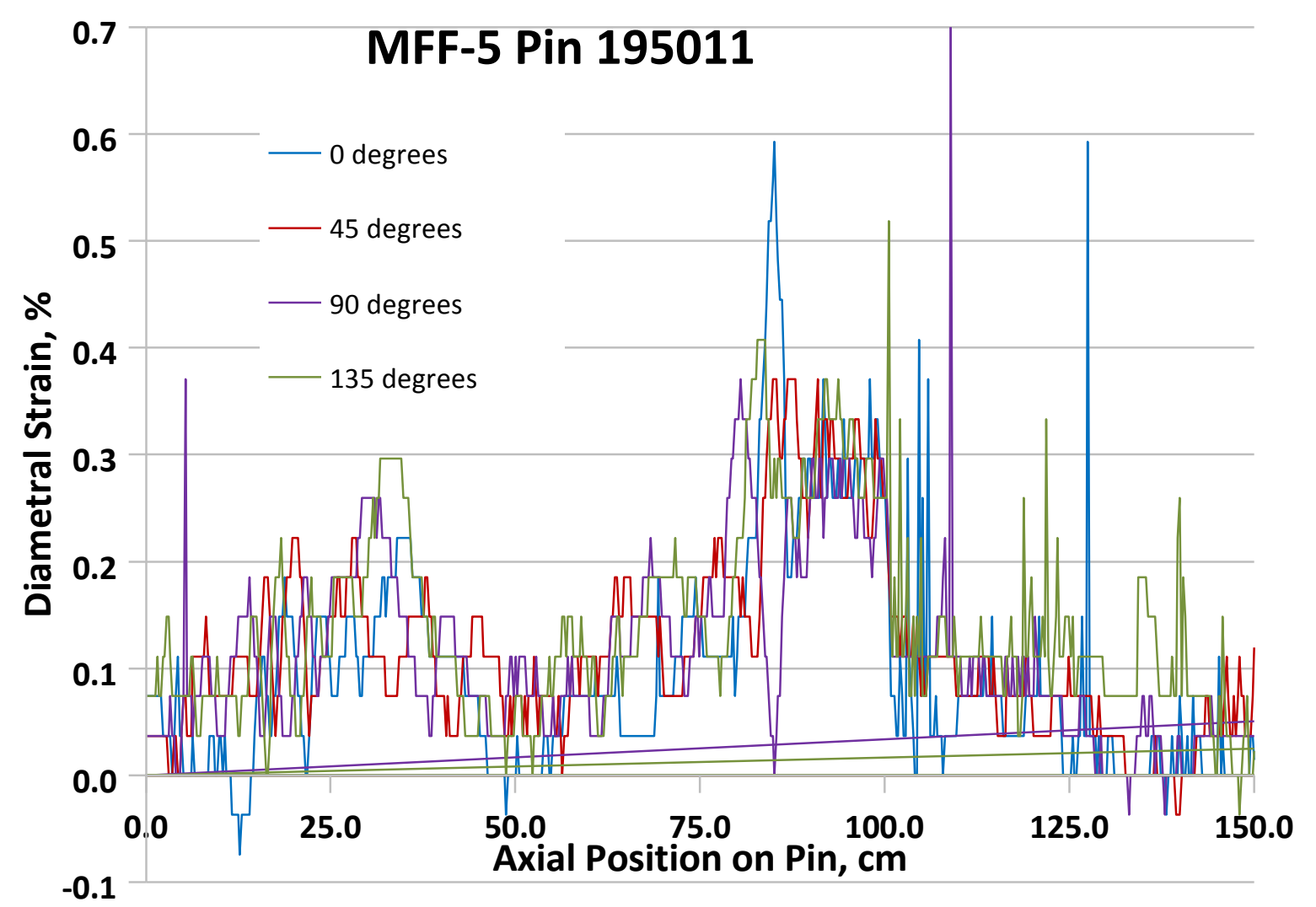

Figure 26. Linear contact profilometry of Pin 195011. Four scans are shown as pin is rotated $45^{\circ}$ between scans. Much of the plenum is not shown to emphasize the fuel column.

The fuel pin with fission gas pressure behaves much like a balanced biaxial tension pressure vessel. This means that deviatoric stresses are only found in the radial and circumferential directions. An internal pressure can cause no permanent axial strain (no axial creep). So, fuel pin length changes can only occur by void swelling of the cladding, or if other stresses are introduced. Assuming the former, fuel pin length changes could be used to estimate the amount of swelling involved in the diameter increases just shown.

If the 'hanging' lengths were used (Table 6), then the diameter increase (0.7-1.2\%) in the MFF-3 tubing could be explained by swelling if the length change was only spread over the lower area of diameter growth. It is assumed the operating temperature is too high for swelling to occur in the upper diameter peak. The lower peak has a width at half maximum of $\sim 20 \mathrm{~cm}$; the smallest pin growth is $\sim 0.5 \mathrm{~cm}$ or $2.5 \%$. This implies too much swelling. The peak strains in the MFF-5 pins are much less, but the apparent length change is as great for MFF-5 pins. Immersion density measurements on the cladding will be required to assess if any void swelling has occurred.

\subsection{Plenum Gas Pressure and Composition (GASR Analysis)}

The gas assay sample and recharge system (GASR) provides the ability to puncture cylindrical capsules or fuel elements in their plenum regions to measure the free volume and pressure and to gather a sample for gas composition and isotopic analyses. With the sampling head secured to the fuel pin cladding, a laser penetrates the cladding wall under the sampling head. The sampler is positioned on the gas plenum region of the fuel pin and when punctured the fission gas in the plenum is released to the GASR system. It is collected into a known volume and the pressure is measured. This provides a measure 
of the total gas in the plenum. A gas sample is taken to measure composition using a gas mass spectrometer. Finally, the fuel pin plenum is backfilled to measure its volume, and this provides a way to calculate the gas pressure that existed in the fuel plenum.

Table 7 provides a predicted amount of fission gas produced during irradiation. It also shows plenum volumes and the pressure and moles of fission gas collected during GASR testing. Based upon these numbers, the final row of the table shows the percentage of gas released. The measured pressure has been corrected to account for the fact that the original was filled with gas at atmospheric pressure; the gas composition was used to provide the best estimate for that correction $(92-93 \%$ of the gas was $\mathrm{Xe}+\mathrm{Kr})$. This changed the release percentage downwards by about 5 percentage points.

Note that the two U-10Zr pins punctured from the IFR-1 experiment showed gas release of 69 and $73 \%$, so in comparison the MFF-3 data looks lower and the MFF-5 looks slightly higher, but in the same range. It appears that a larger data set is required to relate design or operating parameters to gas release.

Table 8 shows the gas composition of two of those pins. Table 9 shows the isotopic ratios of that gas.

Table 7. Fission gas pressure and volume measured for IFR-1 fuel pins.

\begin{tabular}{|l|l|l|}
\hline \multicolumn{1}{|c|}{ Test Number } & MFF-3 & MFF-5 \\
\hline Pin Number & 193045 & 195011 \\
\hline Fuel Type & $\mathrm{U}-10 \mathrm{Zr}$ & $\mathrm{U}-10 \mathrm{Zr}$ \\
\hline Avg Fission density, $10^{21} / \mathrm{cm}^{3}$ & 4.3 & 3.1 \\
\hline Peak BU (a/o) & 13.8 & 10.1 \\
\hline Avg BU (a/o) & 10.85 & 7.61 \\
\hline Fuel Mass, g * & 281.3 & 281.3 \\
\hline Fuel Volume $\left(\mathrm{cm}^{3}\right) *$ & 17.8 & 17.8 \\
\hline Moles of HM burned & 0.116 & 0.081 \\
\hline F.G. generated (moles) & 0.0314 & 0.0233 \\
\hline Plenum Pressure $\left(\mathrm{psi}^{*} \#^{\wedge}\right.$ & 296.6 & 253.2 \\
\hline Plenum Volume $\left(\mathrm{cm}^{3}\right) \#$ & 21.7 & 24.8 \\
\hline Moles Gas in plenum & 0.0190 & 0.0184 \\
\hline Fission Gas Release, $\%$ & 56 & 74 \\
\hline
\end{tabular}

* Design; \# measured (GASR ; ^ corrected for original plenum volume.

The plenum volumes used and listed in the table are those measured during the GASR procedure by back-filling the sampled volume. Those design volumes listed in Table 2 are $28.9 \mathrm{~cm}^{3}$ and $31.5 \mathrm{~cm}^{3}$ for MFF-3 and MFF-5, respectively. The smaller measured volumes are to be expected because when the fuel swells it displaces bond sodium in the original annulus between fuel OD and cladding ID. The porosity in the fuel makes up the extra volume.

The porosity in the fuel is either 'closed' or 'open,' the open porosity can theoretically be connected to the plenum but may contain bond sodium or fission gas. Of course the gas in open porosity, if released during puncturing and creating open plenum volume, would be included in the measured plenum volume and the open volume sampled on refilling, providing an accurate measure of gas release. If gas is trapped in this open porosity then the plenum volume would be underestimated using the measured volume and the amount of released gas underestimated. As a worse case, if the plenum volume were assumed to be 
the as-built volume (no closed porosity) then the volumes would be equal to those design volumes listed above and the gas release would be calculated as $75 \%$ and $86 \%$ for MFF- 3 and MFF-5 respectively. This of course would be an overestimate because there is gas trapped in closed porosity. The point is that there may be some small underestimation in calculating the gas release. This correction has never been applied to previous data so for comparisons this should be ignored.

Table 8. Fission gas composition of the MFF-3 and MFF-5 pins punctured for analysis.

\begin{tabular}{|c|c|c|}
\hline Assembly/Pin No.: & MFF-3/193045 & MFF-5/195011 \\
\hline Gas Composition & \multicolumn{2}{|c|}{ Mol\% } \\
\hline Hydrogen & 0.02 & 0.03 \\
\hline Helium & 7.54 & 6.60 \\
\hline Nitrogen & 0.01 & 0.01 \\
\hline Oxygen & 0.00 & 0.00 \\
\hline Argon & 0.04 & 0.04 \\
\hline Carbon dioxide & 0.02 & 0.04 \\
\hline Krypton & 13.10 & 13.10 \\
\hline Xenon & 78.90 & 79.90 \\
\hline
\end{tabular}

Table 9. Isotopic ratios of the fission gas of the MFF-3 and MFF-5 fuel pins.

\begin{tabular}{|l|l|c|c|}
\hline \multicolumn{2}{|c|}{ Pin Number: } & 193045 & 195011 \\
\hline \multirow{4}{*}{ Element } & Isotope Ratio & \multicolumn{2}{|c|}{} \\
\cline { 2 - 4 } & $124 / 132$ & 0.001 & 0.002 \\
\cline { 2 - 4 } & $126 / 132$ & 0.001 & 0.001 \\
\cline { 2 - 4 } & $128 / 132$ & 0.004 & 0.005 \\
\cline { 2 - 4 } & $129 / 132$ & 0.014 & 0.017 \\
\cline { 2 - 4 } & $130 / 132$ & 0.005 & 0.007 \\
\cline { 2 - 4 } & $131 / 132$ & 0.658 & 0.632 \\
\cline { 2 - 4 } & $134 / 132$ & 1.631 & 1.601 \\
\cline { 2 - 4 } & $136 / 132$ & 1.334 & 1.311 \\
\hline \multirow{5}{*}{ Krypton } & $78 / 84$ & 0.002 & 0.015 \\
\cline { 2 - 4 } & $80 / 84$ & 0.006 & 0.004 \\
\cline { 2 - 4 } & $82 / 84$ & 0.020 & 0.014 \\
\cline { 2 - 4 } & $83 / 84$ & 0.510 & 0.512 \\
\cline { 2 - 4 } & $85 / 84$ & 0.066 & 0.064 \\
\cline { 2 - 4 } & $86 / 84$ & 1.723 & 1.764 \\
\hline
\end{tabular}

\subsection{Optical Metallography}

The two pins selected for destructive examination were sectioned according to the diagram shown in 
Figure 27. Rough section cuts were indexed to the bottom of the fuel pin (tip of spade) and are dimensioned in inches in the drawings. The detailed section cuts were referenced from the bottom of the fuel pin or from the bottom of the lower rough cut.

MFF-3 Sharpie marked end

$\begin{array}{llll}193045 & 22 & 46 & \text { Rough Section Cuts from BOP }\end{array}$

\begin{tabular}{|c|c|c|c|c|c|}
\hline \multirow[t]{2}{*}{$6.5^{\prime \prime}$ Reflector } & \multicolumn{4}{|c|}{$36 "$ Fuel Column } & $92 "$ Fuel pin \\
\hline & 17 & 4 & 13 & 22 & Detailed Section Cuts \\
\hline
\end{tabular}

Sharpie marked end

MFF-5

19

43

Rough Section Cuts from BOP

\section{1}

36" Fuel Column

2.75

11.75

20.75

Measured from sharpie marked end

Figure 27. Sectioning diagram for Pins 193045 and 195011. The detailed cuts show where metallography and burnup samples were taken. Location dimensions are in inches.

The cuts resulted in samples for metallography and chemistry being taken at $\mathrm{X} / \mathrm{L}$ (of the fuel column) 0.03, 0.25, 0.48, 0.74 and 0.98 for Pin 193045 and 0.03, 0.24, 0.48, 0.72 and 0.96 for Pin 195011. For simplicity we will compare like sections here and call them $\mathrm{X} / \mathrm{L}=0.0,0.25,0.5,0.75$ and 1.0. Figure 28 and Figure 29 show the relative positions of each section on the MFF- 3 and MFF-5 pins along with the time averaged operating conditions. 
Table 10 and Table 11 also show the fuel operating conditions.

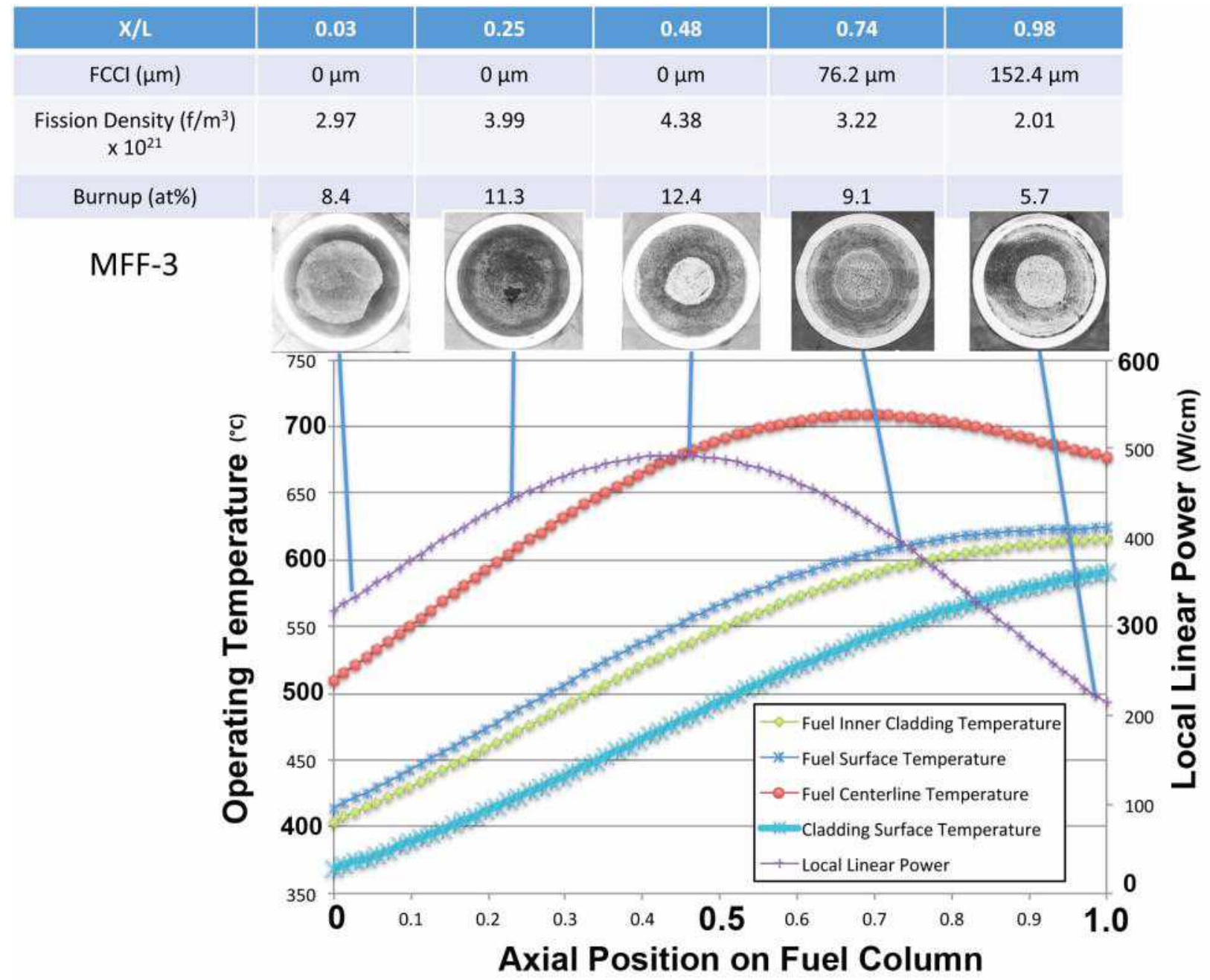

Figure 28. Metallography summary for MFF-3 Pin 193045 showing axial location and operating conditions. Operating conditions are time averaged. 


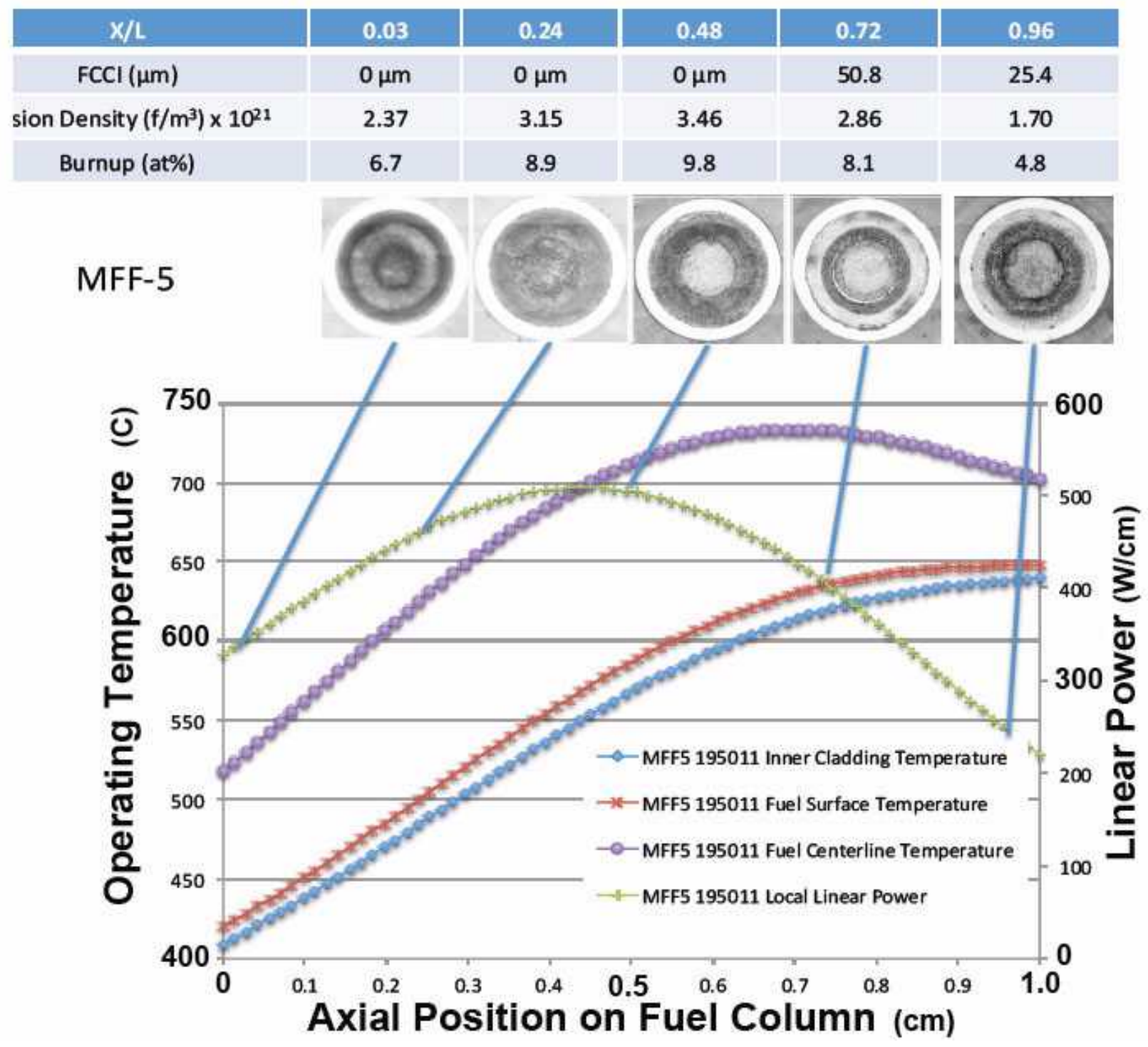

Figure 29. Metallography summary for MFF-5 Pin 195011 showing axial location and operating conditions. Operating conditions are time averaged. 
Table 10. MFF-3 (193045) metallographic section operating conditions.

\begin{tabular}{|c|c|c|c|l|}
\hline $\begin{array}{c}\text { Axial Location } \\
(\mathrm{X} / \mathrm{L})\end{array}$ & $\begin{array}{c}\text { Peak Linear } \\
\text { Power } \\
(\mathrm{W} / \mathrm{cm})\end{array}$ & $\begin{array}{c}\text { Time Averaged } \\
\text { Peak Cladding T } \\
\left({ }^{\circ} \mathrm{C}\right)\end{array}$ & $\begin{array}{c}\text { Time Averaged Peak } \\
\text { Fuel Centerline T } \\
\left({ }^{\circ} \mathrm{C}\right)\end{array}$ & $\begin{array}{c}\text { HM Burnup } \\
\text { (at.\%) }\end{array}$ \\
\hline 0.03 & 334 & 413 & 527 & 8.5 \\
\hline 0.24 & 446 & 475 & 619 & 11.3 \\
\hline 0.48 & 489 & 550 & 700 & 12.4 \\
\hline 0.72 & 359 & 604 & 712 & 9.1 \\
\hline 0.96 & 223 & 615 & 682 & 5.7 \\
\hline
\end{tabular}

Table 11. MFF-5 (195011) metallographic section operating conditions.

\begin{tabular}{|c|c|c|c|c|}
\hline $\begin{array}{c}\text { Axial Location } \\
(\mathrm{X} / \mathrm{L})\end{array}$ & $\begin{array}{c}\text { Peak Linear } \\
\text { Power } \\
(\mathrm{W} / \mathrm{cm})\end{array}$ & $\begin{array}{c}\text { Time Averaged } \\
\text { Peak Cladding T } \\
\left({ }^{\circ} \mathrm{C}\right)\end{array}$ & $\begin{array}{c}\text { Time Averaged Peak } \\
\text { Fuel Centerline T } \\
\left({ }^{\circ} \mathrm{C}\right)\end{array}$ & $\begin{array}{c}\text { HM Burnup } \\
(\text { at.\%) }\end{array}$ \\
\hline 0.03 & 345 & 414 & 532 & 6.7 \\
\hline 0.24 & 461 & 480 & 628 & 8.9 \\
\hline 0.48 & 507 & 556 & 712 & 9.8 \\
\hline 0.72 & 417 & 612 & 738 & 4.8 \\
\hline 0.96 & 249 & 635 & 709 & \\
\hline
\end{tabular}

\subsubsection{MFF-3 Metallography}

\subsubsection{1 $X / L=0.03$}

The $\mathrm{X} / \mathrm{L}=0$ is the position at the bottom of the active fuel column, where the active fuel column and the lower Inconel reflector meet. The metallographic cross-section at $\mathrm{X} / \mathrm{L}=0.03$ is taken just above this in the fuel. It represents the location with the lowest operating temperatures sectioned just above this in the fuel. It is the position that operates at the lowest temperatures.

Figure 30 shows a metallographic cross-section of MFF-3 Pin 193045 taken at the $0.03 \mathrm{X} / \mathrm{L}$ location ( $2.7 \mathrm{~cm}$ up from the bottom of the fuel column). Three are some voids/fission gas bubbles apparent in the central region of the fuel and the large dark areas next to the cladding are void space created by fuel pull-out during the metallographic preparation process. The fuel would be swollen radially enough to contact the cladding but at the low cladding temperatures may not have been bonded to the cladding through FCCI.

There is no evidence of radial zone appearance; none would have been expected. The light dots may be second-phase precipitates (silicides, oxides, carbides) often seen is as-cast fuel and likely very stable in the irradiated fuel, or debris from polishing. This photo was 'stitched' together from a number of smaller photos to provide a high-resolution image across the entire surface. 


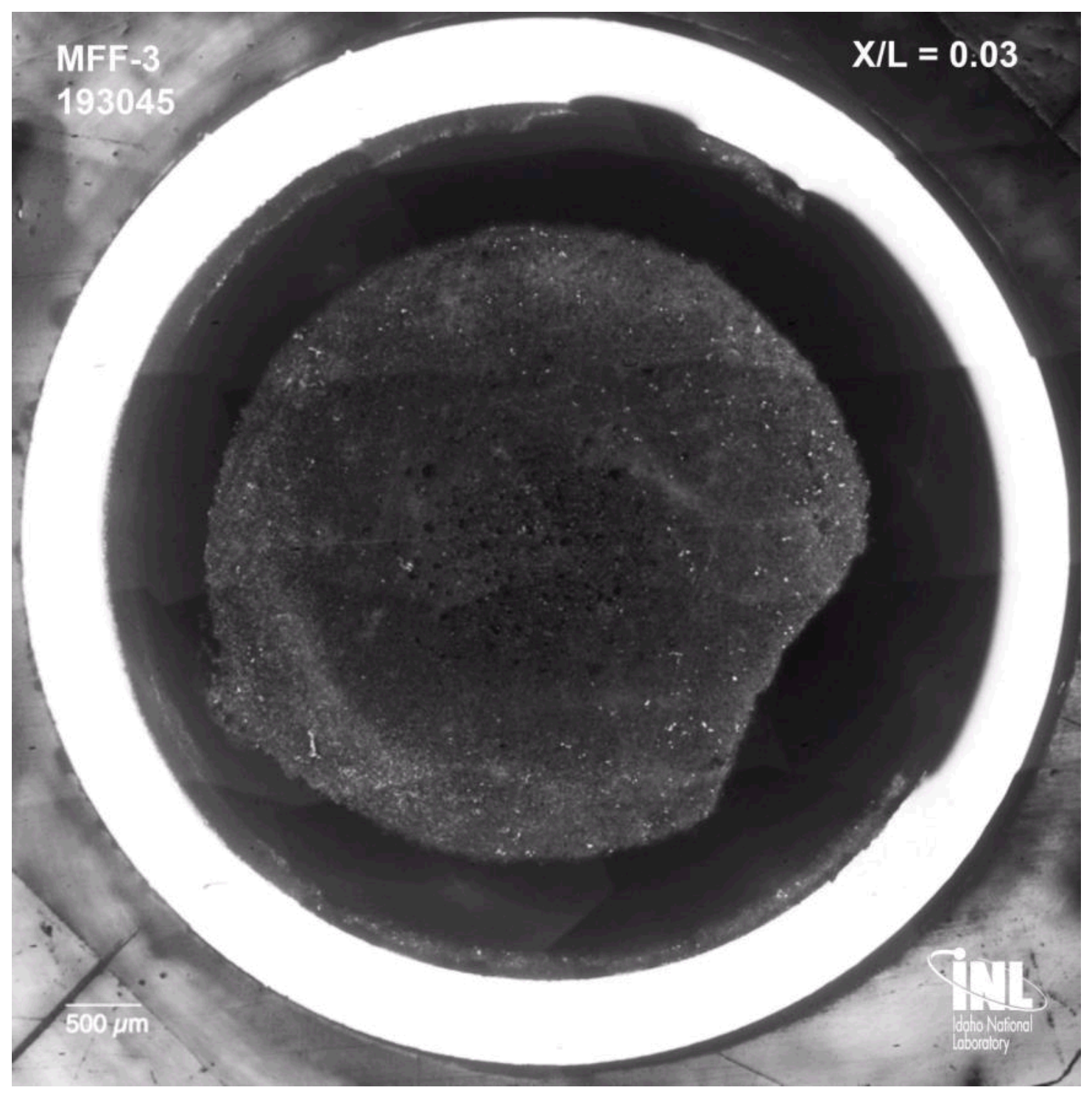

Figure 30. Metallographic section of MFF-3 Pin 193045 at the $\mathrm{X} / \mathrm{L}=0.03$ axial location.

\subsubsection{2 $\quad X / L=0.25$}

The section at $0.25 \mathrm{X} / \mathrm{L}$ is also not complicated. Voids/gas bubbles are evident in the photograph (Figure 31). The large dark area near the center is just a fuel pull-out area created during the metallographic preparation process. Likewise, the best interpretation for the dark areas around the exterior of the fuel, next to the inside surface of the cladding, is also pull-out. The fuel is fully swollen out to the cladding at this level of burnup (11.3 at.\%). The small, aligned dots at some locations on the cladding are indent marks from the hardness testing. The results of this are discussed subsequently in this report. Again there is no evidence of radial zones in the appearance of this section. 


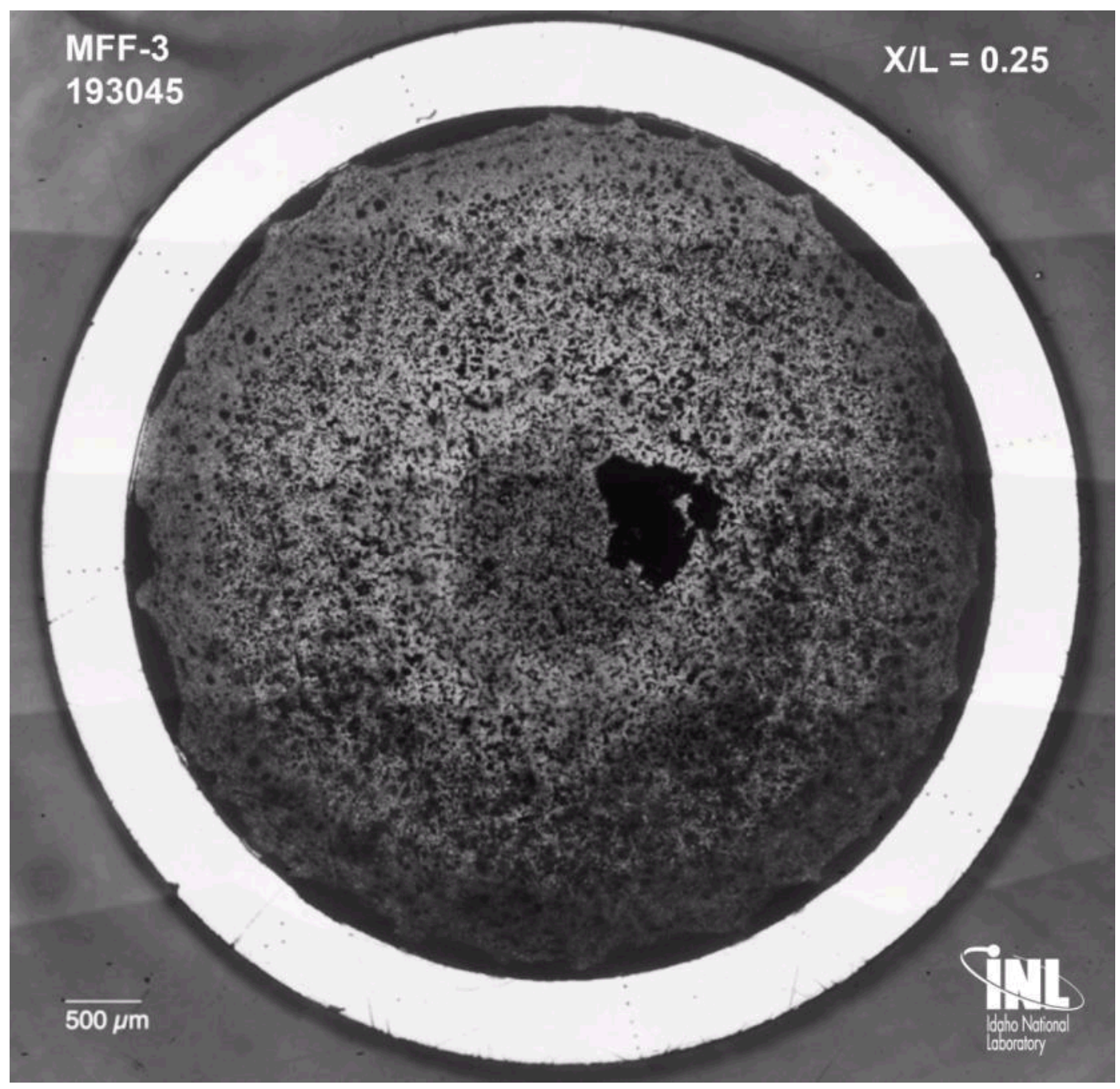

Figure 31. Metallographic section of MFF-3 Pin 193045 at the $\mathrm{X} / \mathrm{L}=0.24$ axial location.

\subsubsection{3 $X / L=0.49$}

The $\mathrm{X} / \mathrm{L}$ location of 0.49 shows the first evidence of radial zones. These are formed at points where radially phase fields are crossed thermally (during fuel operation). It requires crossing into the $\beta+\gamma$ phase field, which exists according to stable phase equilibria at $\mathrm{T} \geq 662^{\circ} \mathrm{C}$, in approaching the fuel center. ${ }^{14} \mathrm{~A}$ portion of the U-Zr phase diagram taken from Reference 14 is shown in Figure 32 to help with the explanation. Hofman et al.'s model ${ }^{14}$ is built around a three-zone model. All three might be present in some of the images from hotter regions (axial) of the fuel but are not obvious - a two-zone structure is more plausible. In the three-zone model the central zone is the $\gamma$ or $\gamma_{1}+\gamma_{2}$ phase field. $\mathrm{Zr}$ is rejected from the $\beta+\gamma$ phase field into the central zone. In their model, ostensibly because of slow diffusion in the $\alpha+\delta$ phase field zone, there is no $\mathrm{Zr}$ migration out of the outer, $\alpha+\delta$ radial zone. The first boundary, approaching the center from the cladding, is the $\alpha+\delta / \beta+\gamma$ phase field boundary. In Figure 33 the boundary between the dark and light colored area would therefore represent the boundary at $662^{\circ} \mathrm{C}$. To form the third, inner zone a fuel temperature regime $>692^{\circ} \mathrm{C}$ is required. 


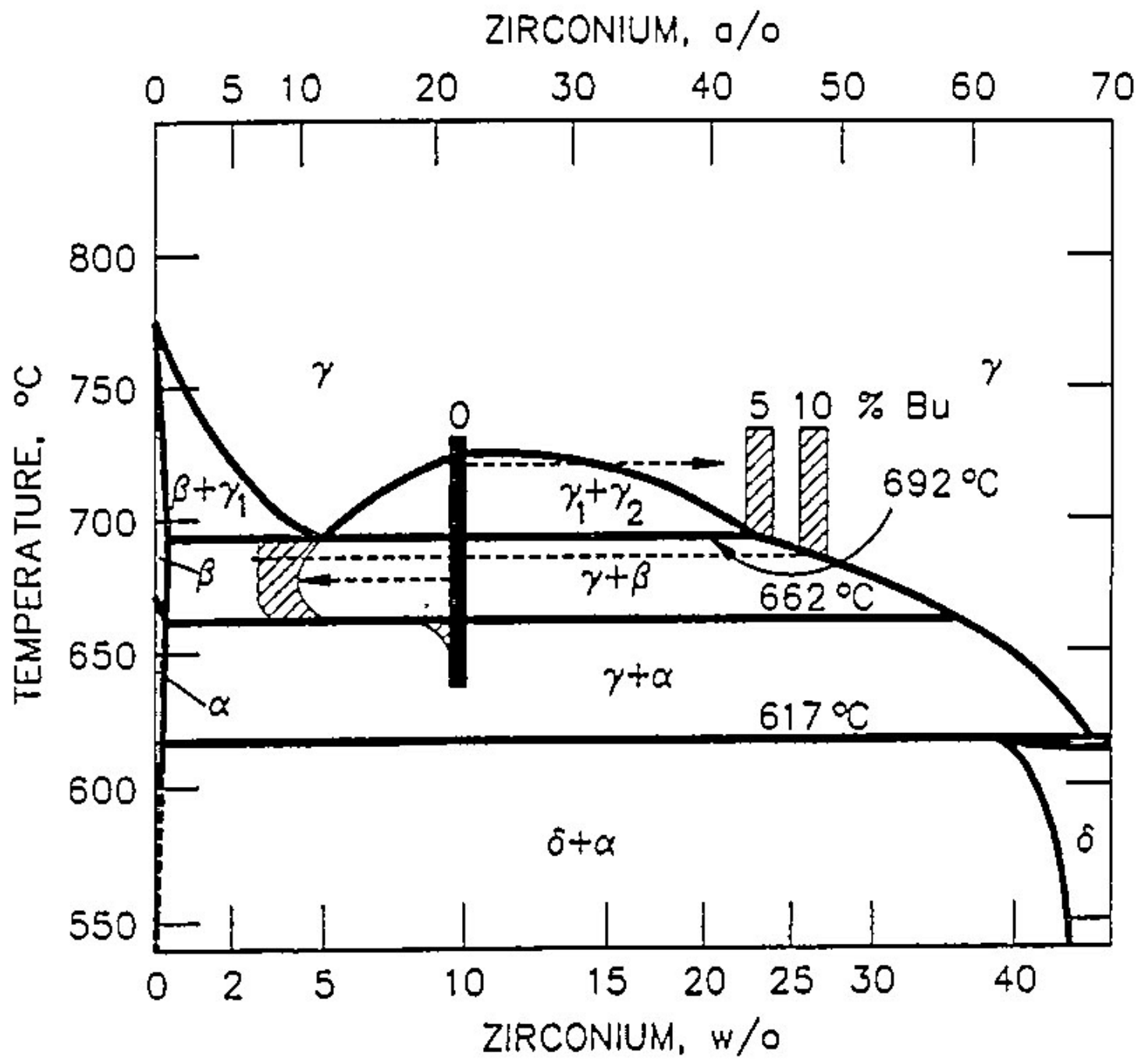

Figure 32. Portion of the U-Zr phase diagram important to U-Zr zone formation (from Ref. 13).

In this case the image appears to represent only the two cooler zones which would indicate that $\mathrm{Zr}$ has migrated out of the $\beta+\gamma$ phase field in the center of the fuel pin to the $\alpha+\delta$ phase field outer zone. The $\delta$, or $\mathrm{UZr}_{2}$ phase is not thermodynamically modeled in their paper and perhaps the phase is relatively stable, compared to the $\gamma$ phase, and that as the $\mathrm{Zr}$ migrates to the cooler zone further $\mathrm{UZr}_{2}$ is precipitated. The two-zone structure has frequently been observed in U-Pu-Zr fuels. ${ }^{15}$ Of course further analysis, such as by electron microprobe (EPMA), would be required to show the $\mathrm{Zr}$ concentration profile, to prove that $\mathrm{Zr}$ has migrated radially outward, or to uncover the presence of a third, central zone. 


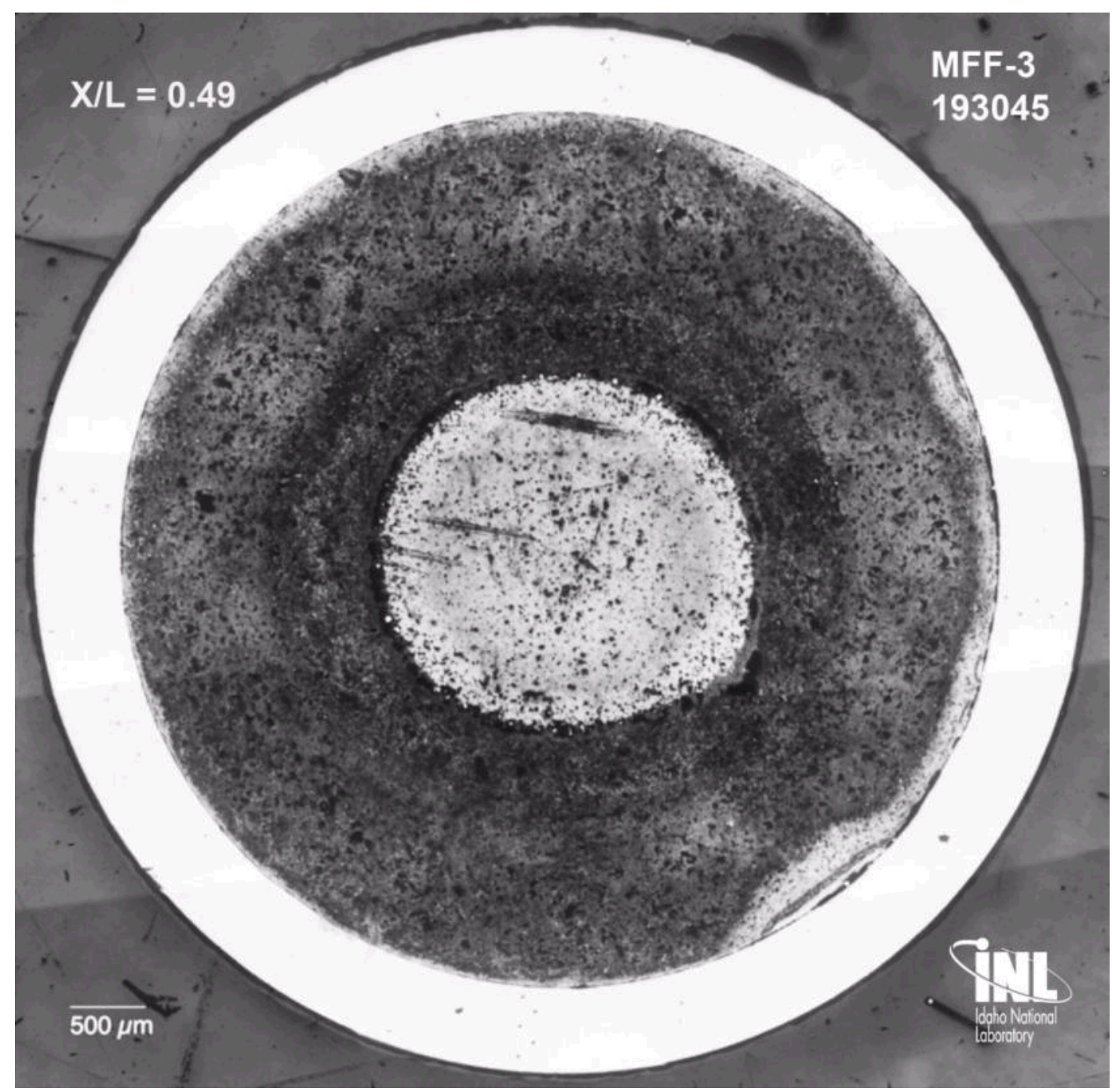

Figure 33. Metallographic section of MFF-3 Pin 193045 at the $\mathrm{X} / \mathrm{L}=0.49$ axial location.

\subsubsection{4 $X / L=0.74$}

Note that the central volume is largest at this location. Testing the assumption that this fits the $\beta+\gamma$ phase field $\left(\mathrm{T}>662^{\circ} \mathrm{C}\right)$ the time-averaged fuel centerline temperature (Figure 10) would predict that this metallographic section would have the largest central zone. The image perhaps indicates a third zone in the center where the gas bubbles are larger, but again EPMA may be required to prove its presence. Also, there may have been a third zone when the fuel was swelling early in life, but as the fuel cooled due to $\mathrm{U}$ depletion it reverted to $\gamma+\beta$.

There is evidence of fuel/cladding interaction (see light-colored areas in the fuel at the top, 12 o'clock position); most of the interaction area is in the fuel where cladding components (especially $\mathrm{Fe}$ ) have diffused into the fuel. There is some cladding thickness reduction in those areas. This FCCI is very non-uniform around the circumference of the fuel, as is usually observed in this fuel/cladding combination. The typical FCCI zone formed in the cladding by rare earth fission products diffusing into the cladding is not apparent in Figure 34. 


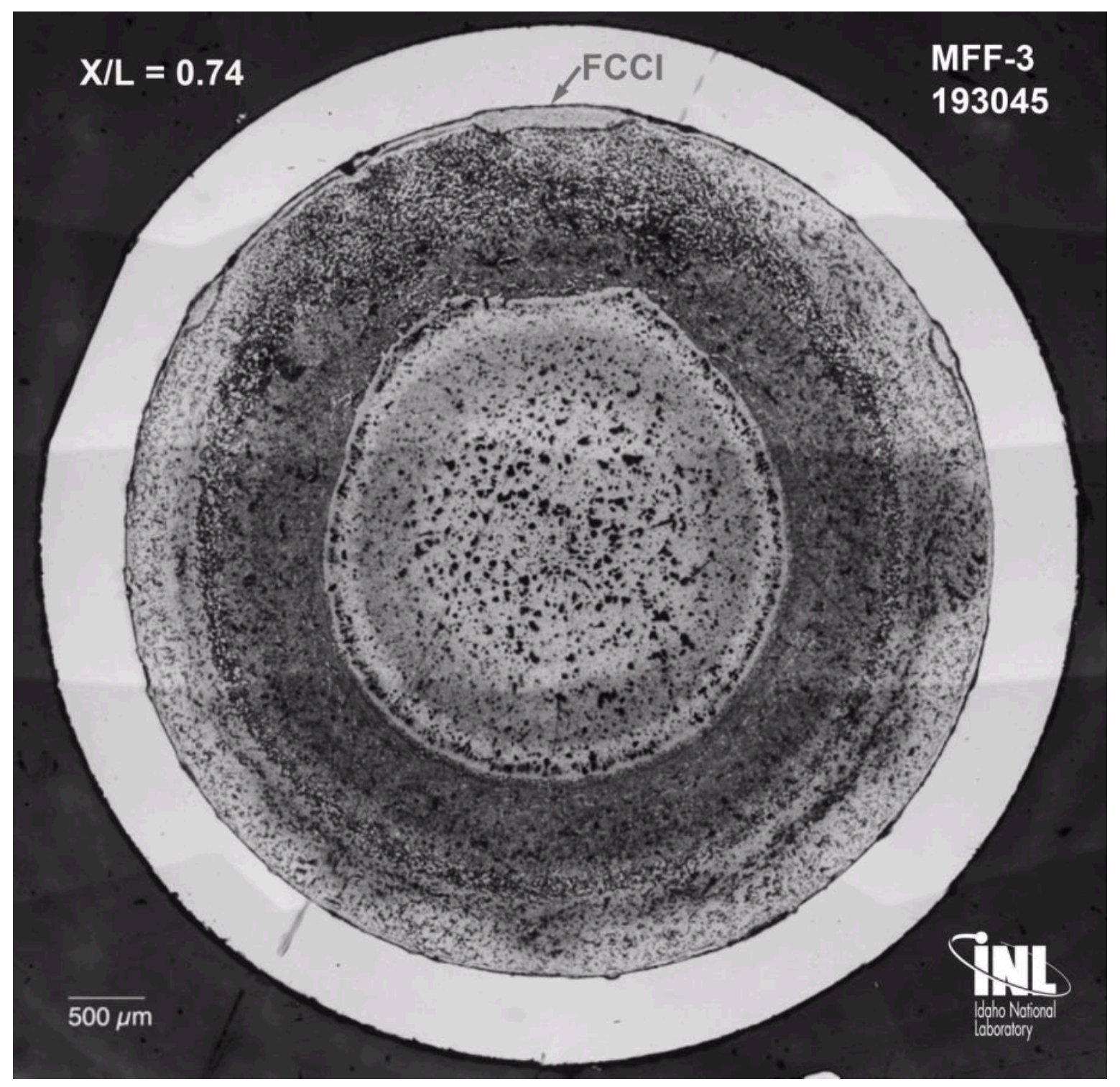

Figure 34. Metallographic section of MFF-3 Pin 193045 at the X/L $=0.74$ axial location.

\subsubsection{5 $\quad X / L=0.98$}

The overall appearance, as shown in Figure 35, is that of a two-zone structure. The light-colored central volume therefore represents one that operated in the $\beta+\gamma$ phase field which exists according to stable phase equilibria at $\mathrm{T}>662^{\circ} \mathrm{C}$. The time-averaged fuel centerline temperature at this elevation see (Figure 10) is above $662^{\circ} \mathrm{C}$. Compared to the $0.74 \mathrm{X} / \mathrm{L}$ location the fuel temperatures here are lower and hence the smaller central volume.

Figure 10 would predict that the fuel center be about the same temperature (averaged) as the $\mathrm{X} / \mathrm{L}=0.49$ location but at lower power, so the temperature gradient is not as large from the center to the outside surface at $\mathrm{X} / \mathrm{L}=0.98$. Hence a slightly larger central zone may be expected and this zone does appear slightly larger than that in Figure 33.

The fuel/cladding interaction was measured to be largest in this location, and does appear to be far more uniform around the circumference than at the other location. There is some staining on the surface of the cladding which should be ignored. 


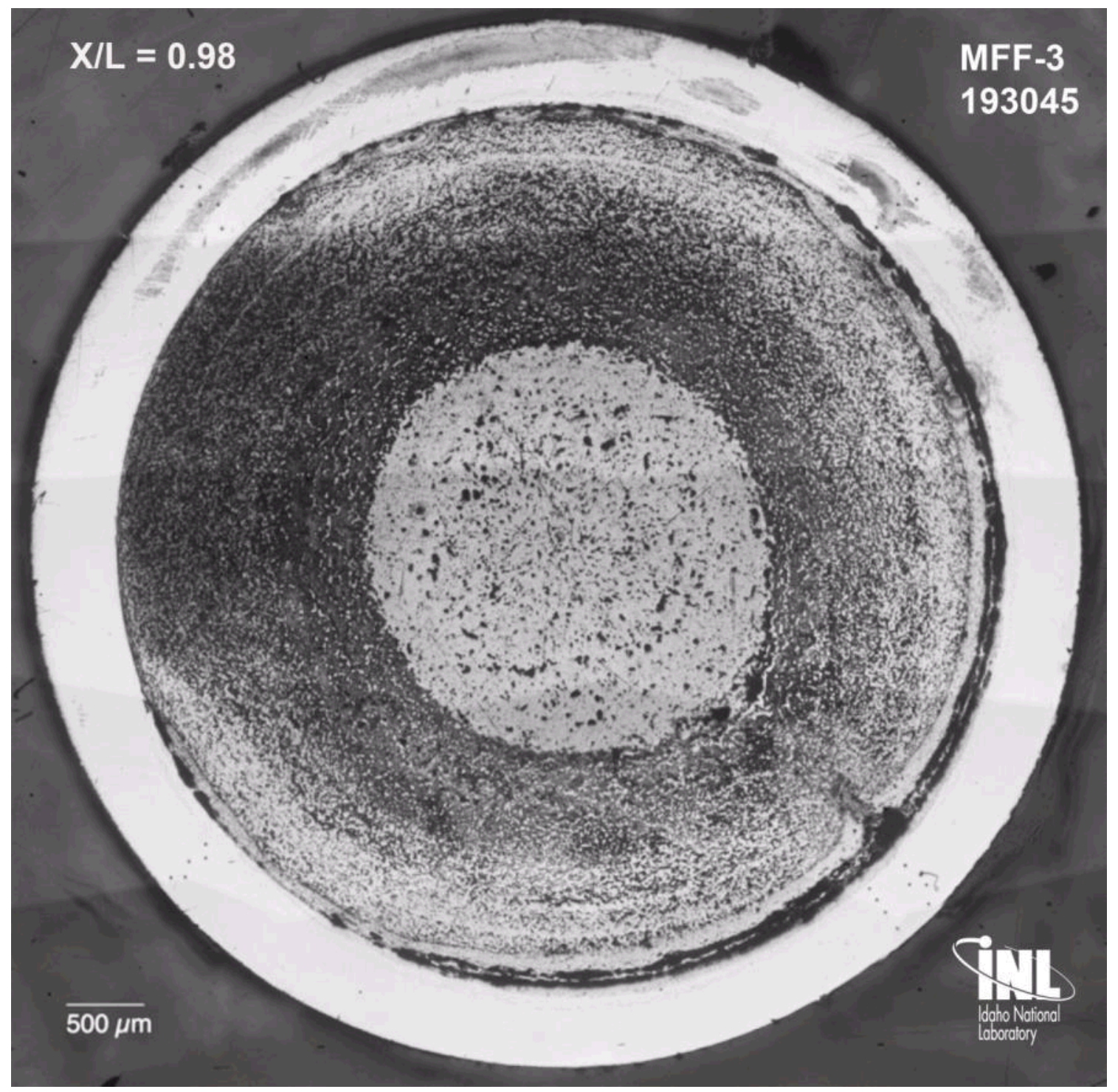

Figure 35. Metallographic section of MFF-3 Pin 193045 at the X/L $=0.98$ axial location.

An enlargement of a portion of the image shown in Figure 35 is shown in Figure 36. It shows the FCCI region of maximum depth. This layer has the appearance of a typical FCCI zone where rare earth fission products have diffused into the cladding. ${ }^{16}$ 


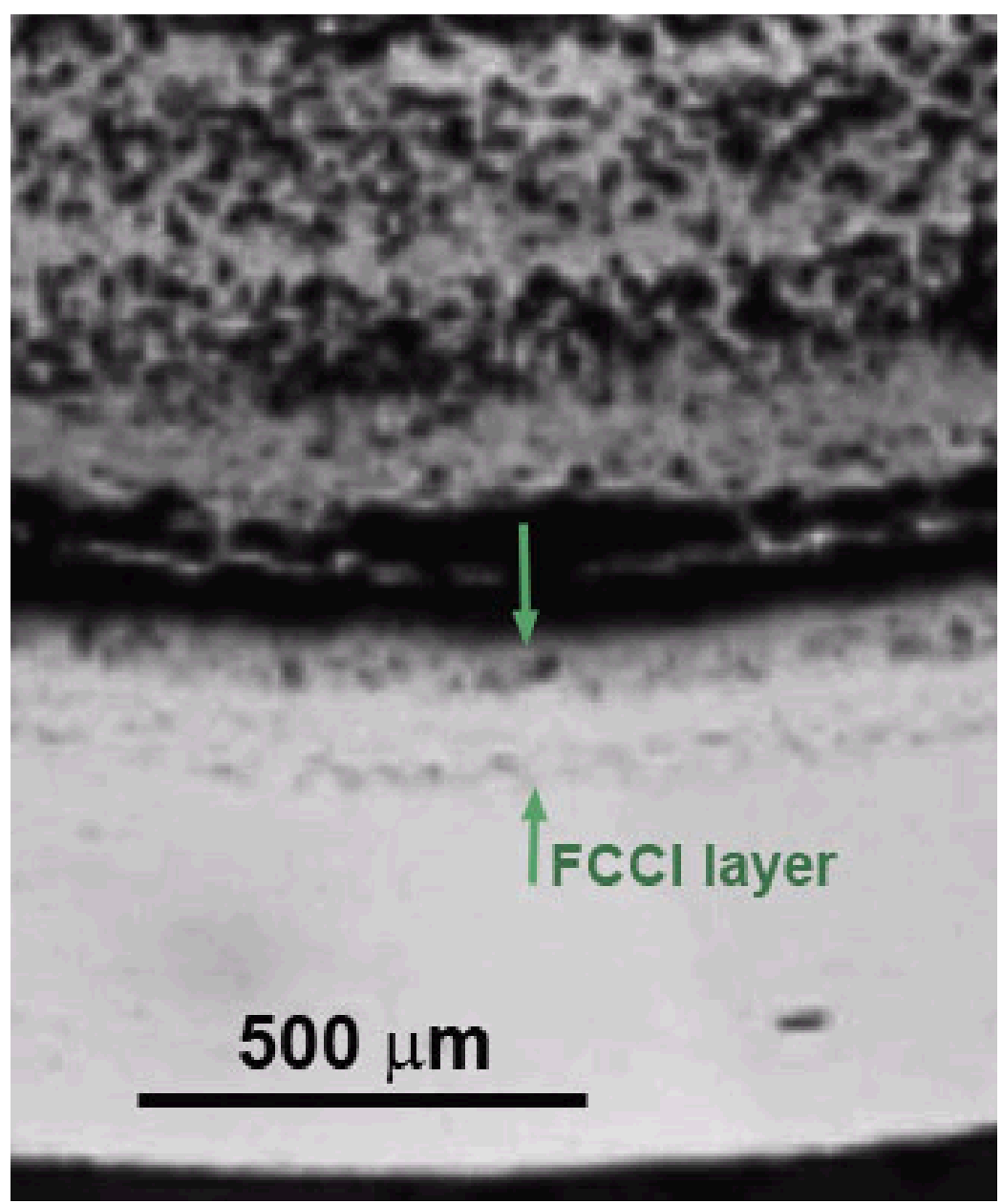

Figure 36. Area of fuel/cladding chemical interaction $(\mathrm{FCCI})$ in the $\mathrm{X} / \mathrm{L}=0.98$ cross-section of Pin 193045.

\subsubsection{MFF-5 Metallography}

The following images show as-polished cross-sections of MFF-5 Pin 195011. Operating conditions of the fuel pin at these locations were given in Table 11.

\subsubsection{1 $X / L=0.03$}

Figure 37 shows the same appearance as the lower section of the MFF-3 pin, including a large fraction of fuel pull-out near the outer diameter of the fuel slug. It shows no evidence of zone formation as would be expected by its operating temperatures, nor does it show any evidence of FCCI. 


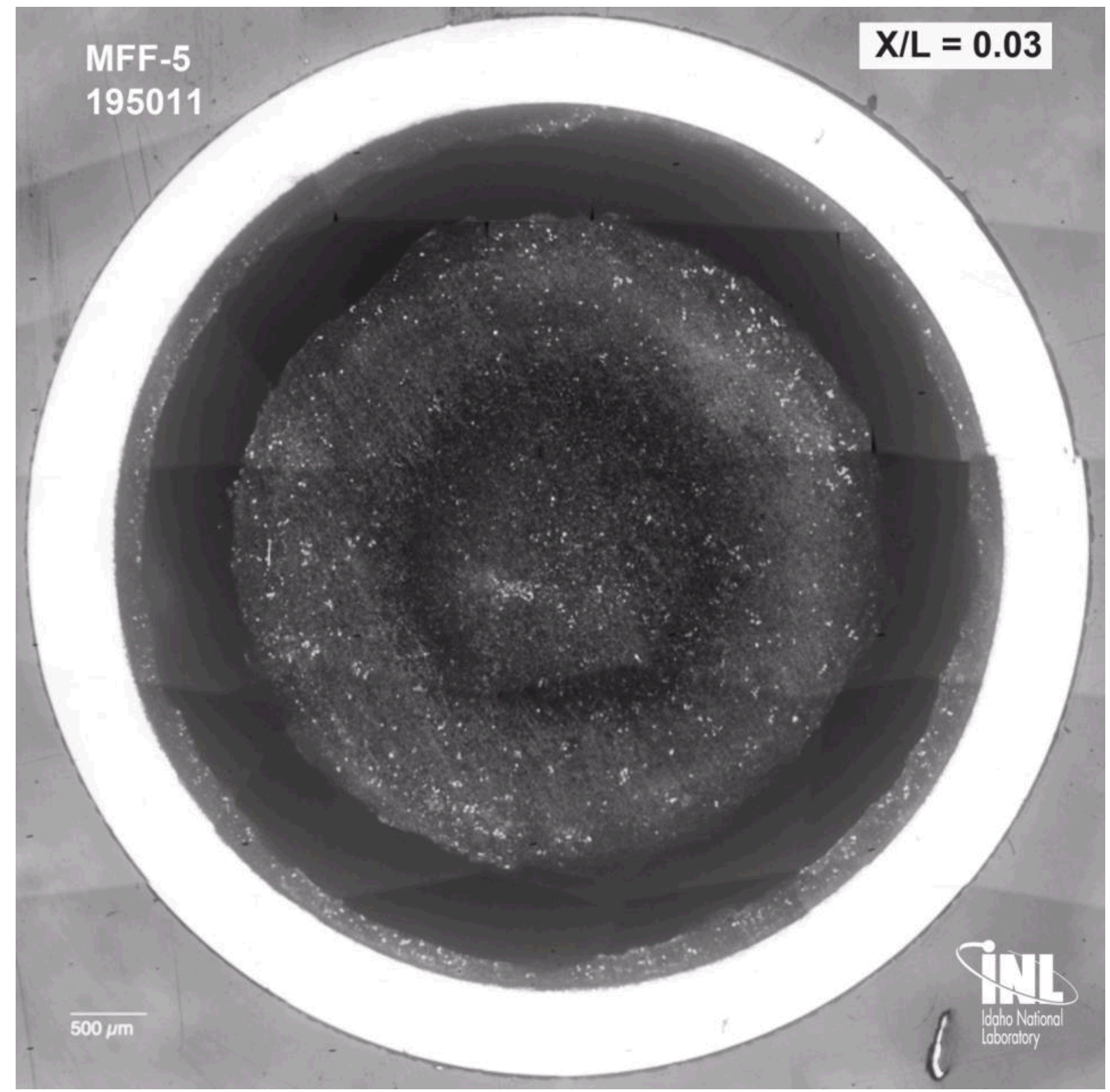

Figure 37. Metallographic section of MFF-5 Pin 195011 at the $\mathrm{X} / \mathrm{L}=0.03$ axial location.

\subsubsection{2 $\quad X / L=0.24$}

As with the previous section at $\mathrm{X} / \mathrm{L}=0.03$ this section at $\mathrm{X} / \mathrm{L} /=0.24$, Figure 38 , looks to have the same features as that of the MFF-3 pin at $\mathrm{X} / \mathrm{L} /=0.25$. There is no zone formation or obvious FCCI. 


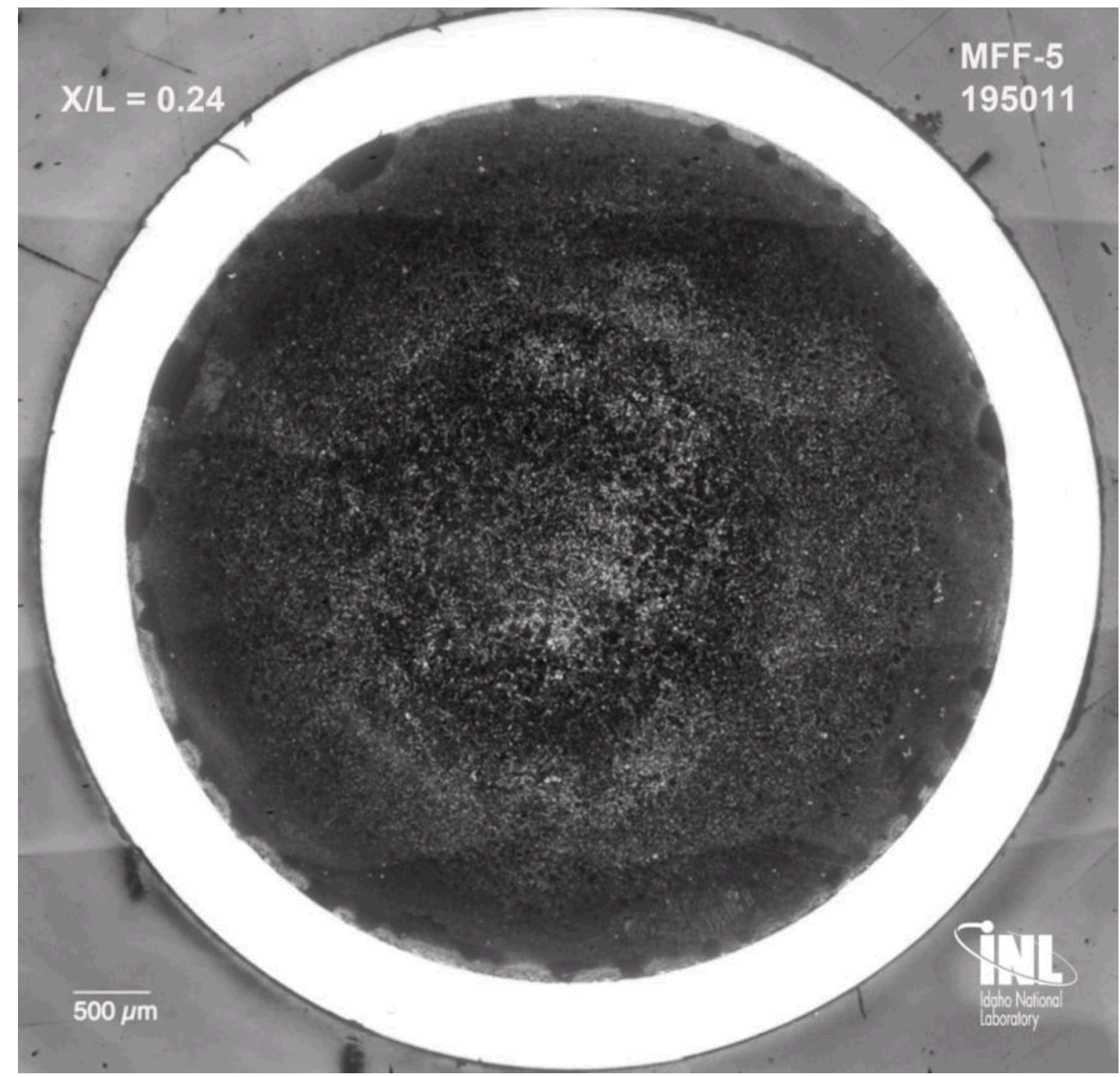

Figure 38. Metallographic section of MFF-5 Pin 195011 at the $\mathrm{X} / \mathrm{L}=0.24$ axial location.

\subsubsection{3 $\quad X / L=0.48$}

Figure 39 shows the polished section at $\mathrm{X} / \mathrm{L}=0.48$. It displays a typical two-zone structure. There are areas around the circumference of the cladding inner diameter that indicate that there may be some fuel/cladding chemical interaction. The apparent FCCI however may be artifacts from polishing. The as-polished surface appearances are discussed here. In the subsequent section of this report (Cladding Metallography and FCCI) the appearance of the etched cladding, cladding microhardness results, and depth of FCCI are discussed. 


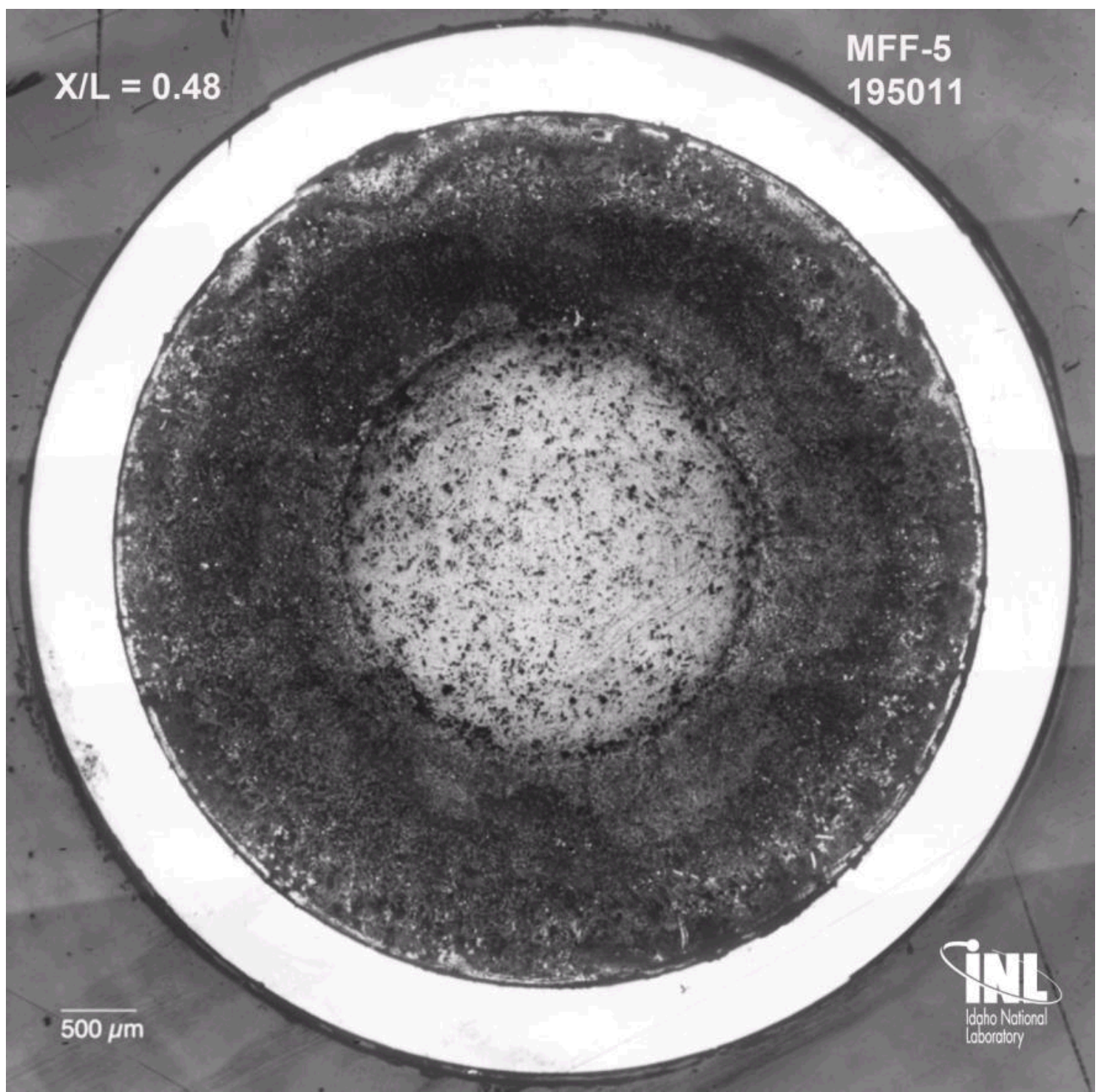

Figure 39. Metallographic section of MFF-5 Pin 195011 at the $\mathrm{X} / \mathrm{L}=0.48$ axial location.

\subsubsection{4 $X / L=0.72$}

The metallographic section of pin 195011 at $\mathrm{X} / \mathrm{L}=0.72$ shows the first indications of the three-zone structure (Figure 40). This would imply that the $\mathrm{Zr}$ concentration in the outer zone had changed very little, perhaps increasing slightly, the banding at mid-radius representing the second zone would be very reduced in $\mathrm{Zr}$ concentration, and the central zone enriched in $\mathrm{Zr}$. The mid-radius zone however usually polishes very well and appears lighter in color; it appears dark in color here. Near end of life the operating temperature of the fuel center may have reduced enough so that it was operating less than $692^{\circ} \mathrm{C}$, or whatever the non-equilibrium temperature is representing the $[\beta+\gamma]$-to- $\left[\gamma_{1}+\gamma_{2}\right]$ phase field boundary.

One question is why the MFF-5 pin may have shown a three-zone structure when the MFF-3 pin did not. The MFF-5 assembly did not operate to as high a burnup as MFF-3, resulting in a significantly higher operating temperature when time averaged. Figure 28 and Figure 29 show these values. The latter stages of MFF-3 Pin 193045 operation had considerably lower fuel temperatures due to the fissile depletion. Note that Pin 193045 had latter stage (last three cycles) peak linear power of about $350 \mathrm{~W} / \mathrm{cm}$ while MFF-5 Pin 195011 ranges from $385 \mathrm{~W} / \mathrm{cm}$ to $415 \mathrm{~W} / \mathrm{cm}$. 
A comparison of Table 10 with Table 11 also shows the operating temperature differences on average. The fact that the average and end-of-life fuel centerline temperatures are expected to have been higher in MFF-5 means that microstructures may reflect this, reflecting a significant central zone operating for an extended time at $\mathrm{T}>692^{\circ} \mathrm{C}$. As the $\mathrm{U}$ was depleted and the pin power diminished, the mid-radius zone retreated towards the center and eventually consumed it, leaving gas bubble morphologies reminiscent of the previous zone structure.

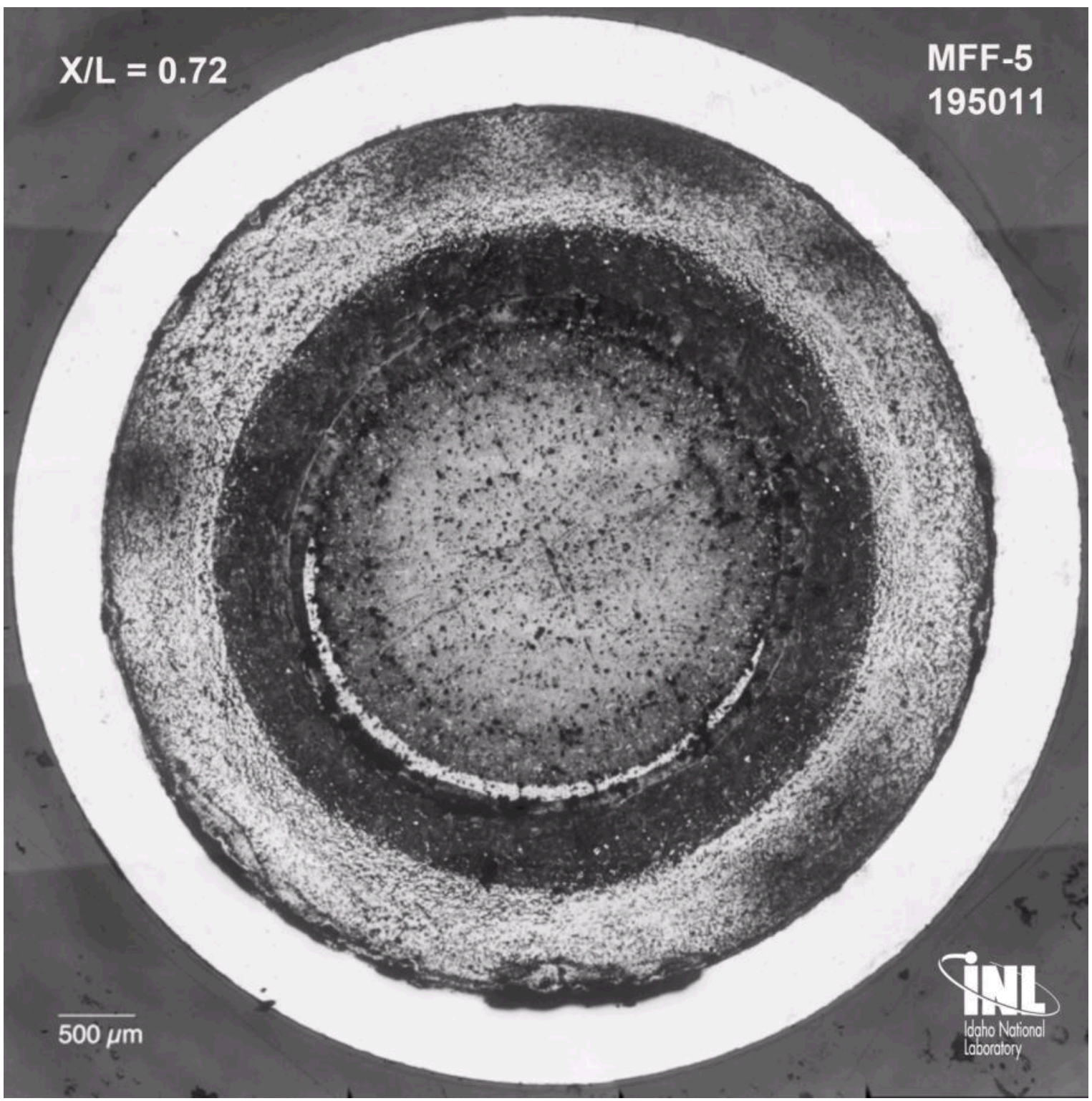

Figure 40. Metallographic section of MFF-5 Pin 195011 at the $\mathrm{X} / \mathrm{L}=0.74$ axial location.

\subsubsection{5 $X / L=0.96$}

The appearance of the cross-section at $\mathrm{X} / \mathrm{L}=0.96$ (Figure 41) looks something like that shown in the image of the $\mathrm{X} / \mathrm{L}=0.76$ section. It has what now looks like a two-zone structure but the outer zone looks as though it may have been two zones at some time. Of course only a radial analysis of the $\mathrm{Zr}$ concentration will help prove or disprove this hypothesis, which may be important to fully benchmark a model for $\mathrm{Zr}$ redistribution. The importance of this model is in predicting the melting temperatures of the various zones as they are affected by $\mathrm{Zr}$ concentration. 


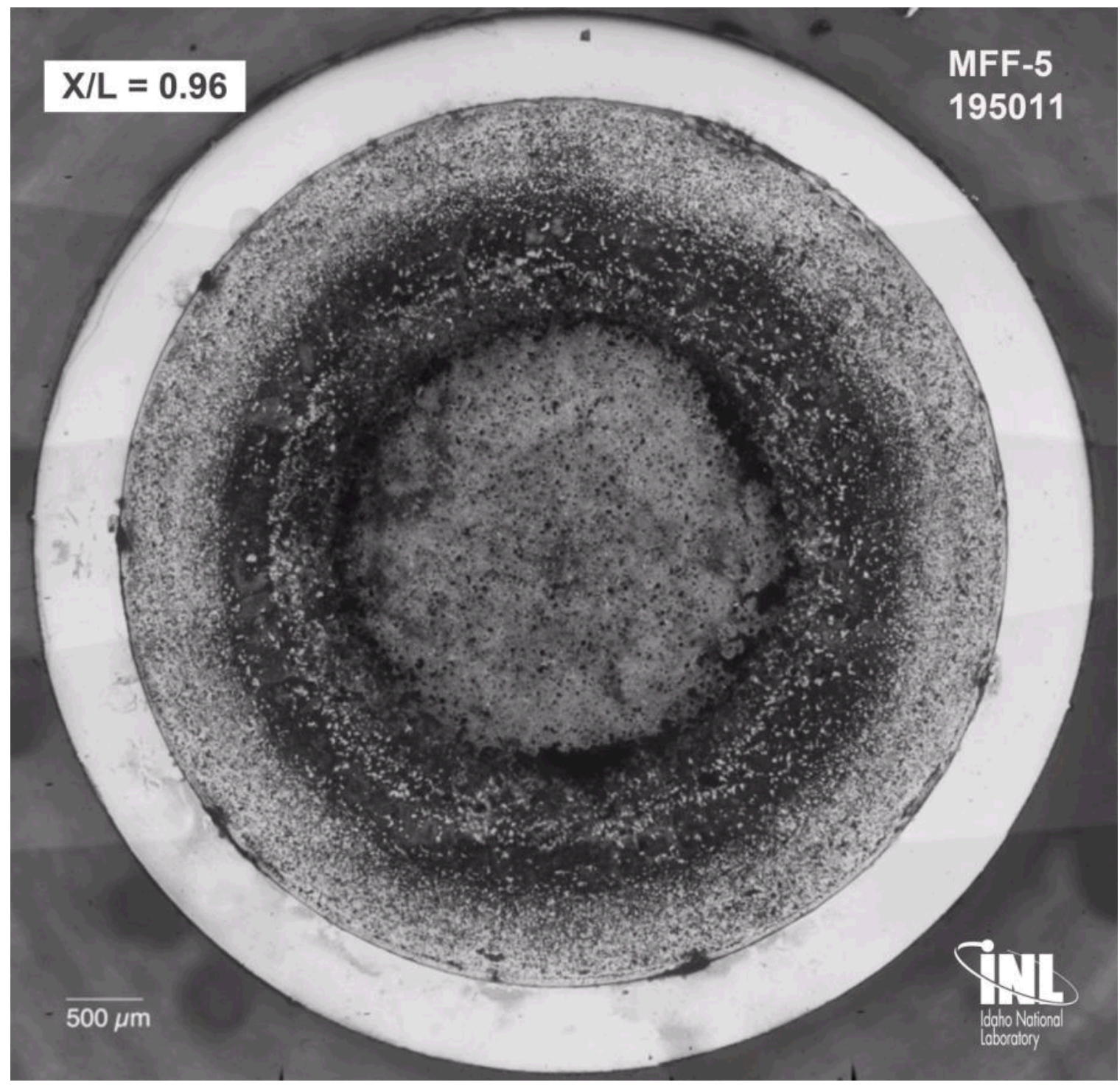

Figure 41. Metallographic section of MFF-5 Pin 195011 at the $\mathrm{X} / \mathrm{L}=0.96$ axial location.

\subsubsection{Cladding Metallography and Fuel/cladding Chemical Interaction (FCCl)}

Fuel/cladding interaction can take several forms in regards to metallic fuel and HT9 cladding. The interdiffusion of rare earth fission products and cladding components is considered the most important as it produces a diffusion layer in the cladding that is brittle and considered cladding wastage, and sometimes contains low melting compounds. This FCCI effect in the MFF pins has been analyzed in considerable depth and modeled as part of a Ph.D. dissertation ${ }^{17}$ and will be summarized later in this section.

A second effect is that the small carbides created in the cladding during tempering of the steel can dissolve and be transported into the fuel, effectively decarburizing the cladding. Figure 42 shows the results of this phenomenon where a U-Pu-Zr piece of fuel was sandwiched with HT9 cladding and heated to $705^{\circ} \mathrm{C}$ for $300 \mathrm{hr} .{ }^{18}$ The HT9 has been decarburized to a depth of about 620 microns. Note that the now ferritic decarburized region also shows grain growth and is very soft (hardness indents are large). This same effect has been observed in HT9 cladding on metallic fuel so hardness testing and cladding etching will be used to examine for this effect in the MFF pins. 


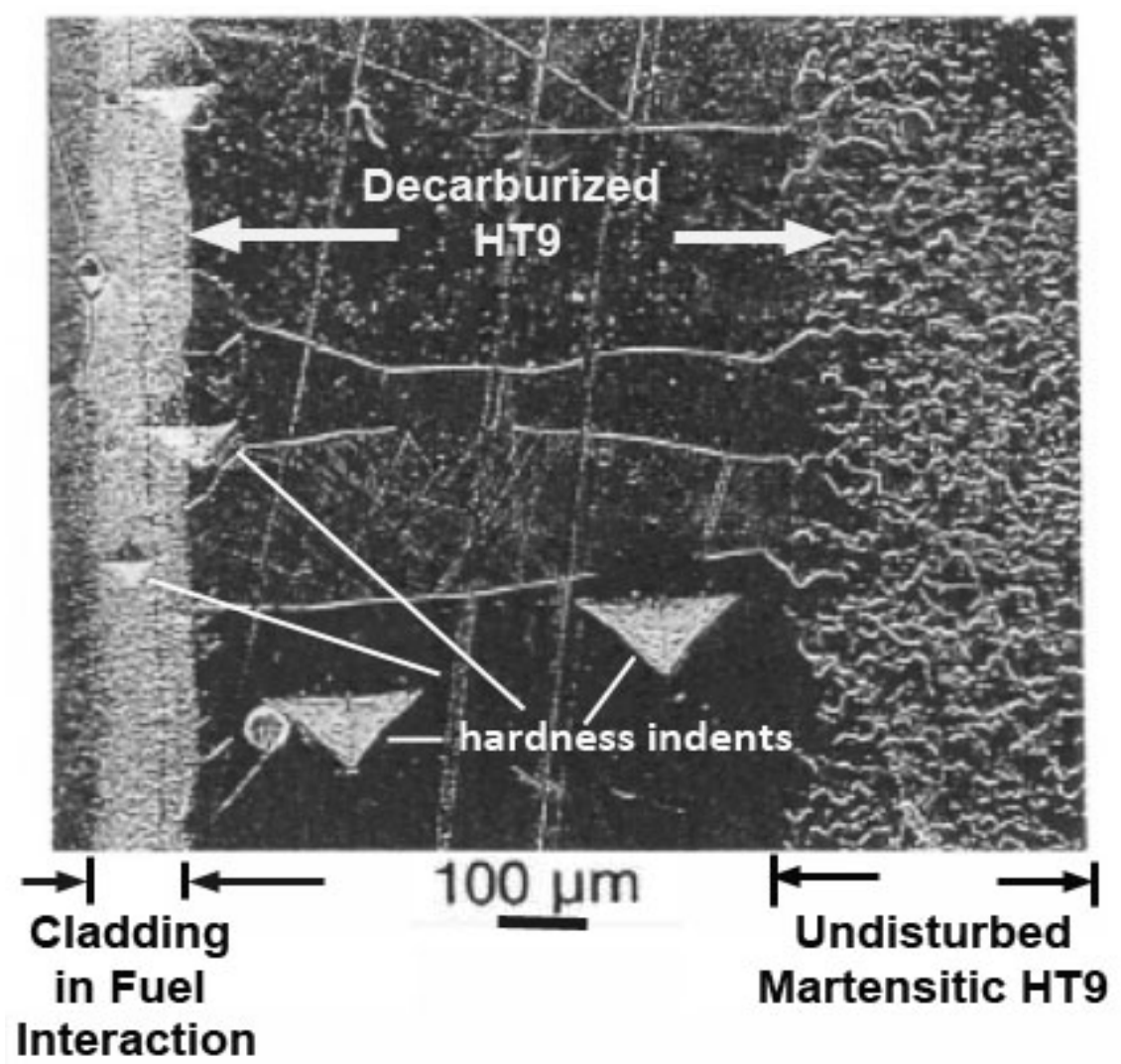

Figure 42. Polished and etched surface cut across diffusion couple of U-Pu-Zr fuel and HT9 cladding. $705^{\circ} \mathrm{C}$ for $300 \mathrm{hr}$. Large hardness indents show soft, decarburized area of large-grain ferrite in the HT9.

Figure 43 and Figure 44 graphically show some of the microhardness measurements taken on the HT9 cladding surfaces in the metallography samples of Pins 193045 and 195011. The data plotted include individual measurements taken closest to the OD of the cladding and closest to the fuel (cladding ID) at each $90^{\circ}$ rotation around the circumference of the cladding. The average of those for each axial location is also shown.

Note that the hardness in general decreases going up the fuel pin OD, and are lower for the measurements taken closest to the cladding ID. This likely reflects the cladding temperature and an over-tempering phenomenon, counteracted only by some radiation hardening. The latter is reflected by the slight increase in hardness at core center $(\mathrm{X} / \mathrm{L}=0.5)$. None of these hardness measurements reflect softening from carbon loss or hardening from rare earth fission product diffusion into the cladding although a few such measurements were made that reflect these phenomena. 


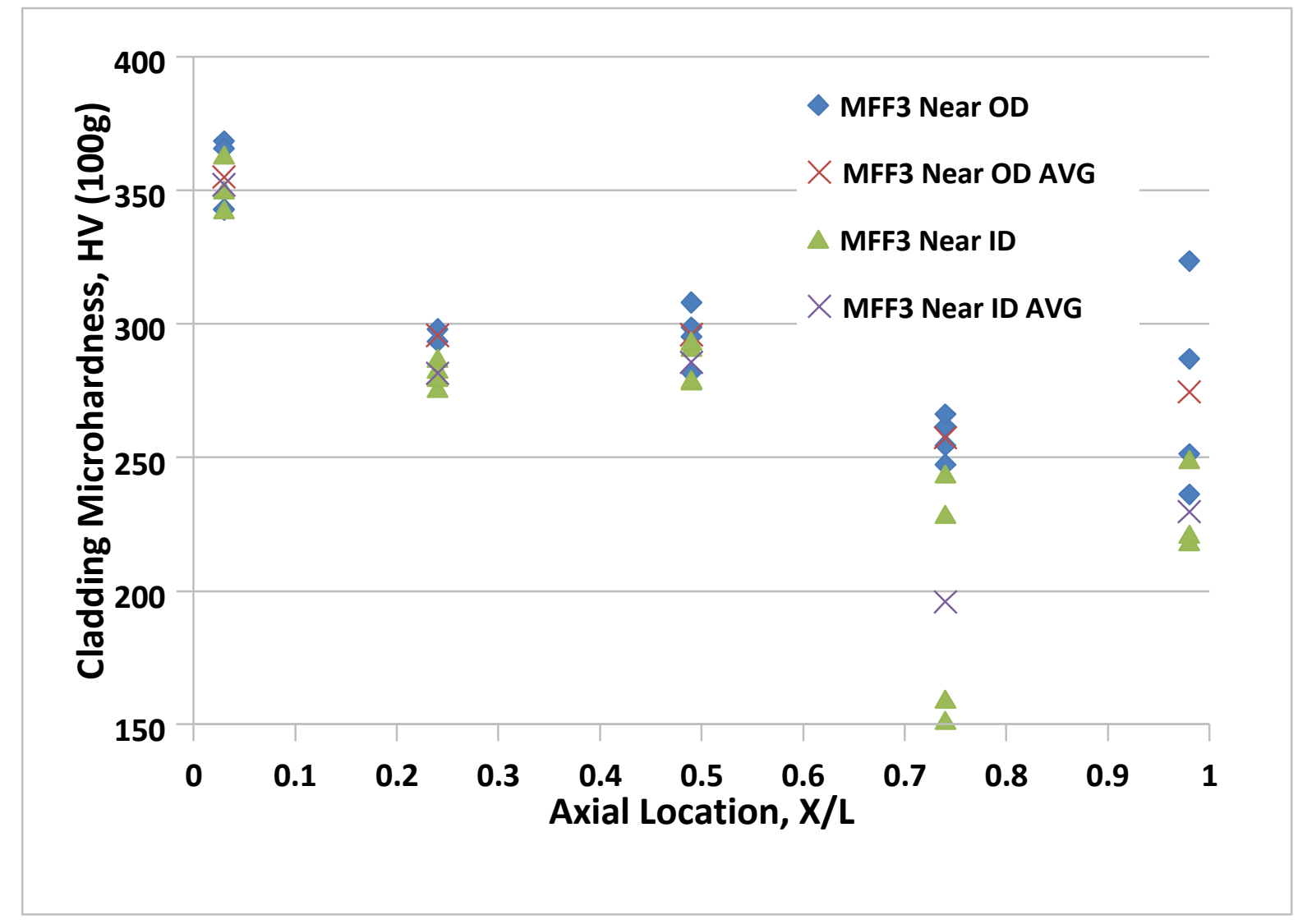

Figure 43. MFF-3 Pin 193045 HT9 cladding microhardness as a function of axial location. 


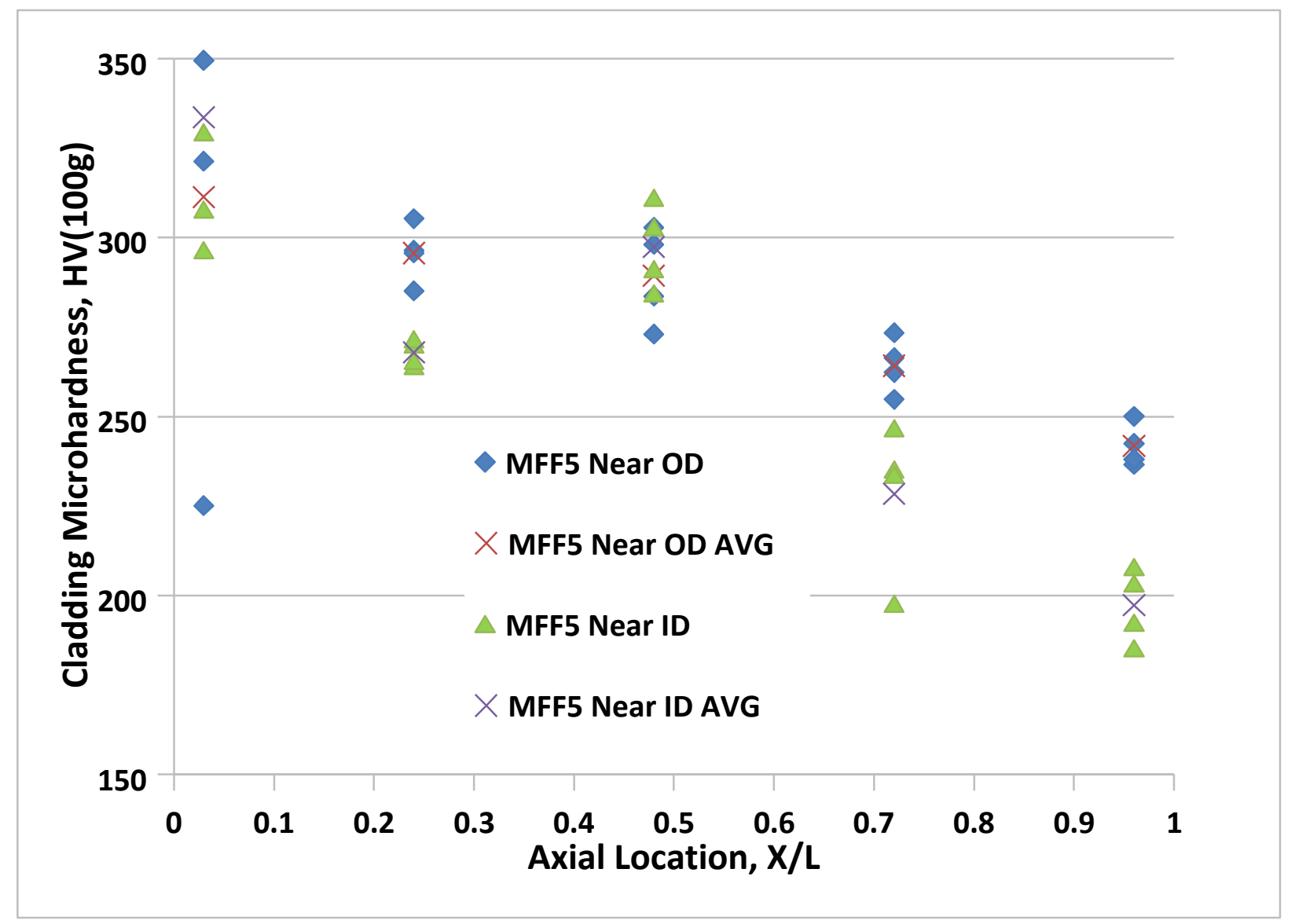

Figure 44. MFF-5 Pin 195011 HT9 cladding microhardness as a function of axial location.

The measured peak FCCI values were shown in Figure 28 and Figure 29, and the FCCI maximum depth along with time-averaged inner clad temperature and fuel centerline temperature are shown in Table 12. The values predicted by the model developed by Carmack are also shown. ${ }^{17}$ These values represent only the rare earth fission product interaction with the cladding. The MFF-5 pin shows a peak interaction between the middle and top of the fuel column, the same behavior as seen in an earlier FFTF experiment (IFR-1) and attributed to the effect of higher driving force (temperature gradient) in moving rare earths to the cladding surface. The MFF-3 pin shows a peak near the top of the fuel column. Note that both MFF-3 and MFF-5 operated at significantly higher cladding temperatures than did IFR-1.

As mentioned previously Reference 17 presents a treatise on the FCCI of these pins, and others from an experiment, X447, run in EBR-II. All were experiments which were run with very high peak cladding temperatures and therefore presented the most FCCI. A model was developed based upon the diffusion of rare earth fission products through the fuel induced by both Fickian (concentration gradient) and Soret (thermal gradient) effects and a subsequent reaction of these fission products with the cladding. The model predicted the FCCI layer growth, if not the exact magnitude of the temperature dependence, as seen in the sample graphical representation for MFF-5 Pin 195011, in Figure 45.

Table 12. Fuel/cladding interaction layer depth as a function of axial position.

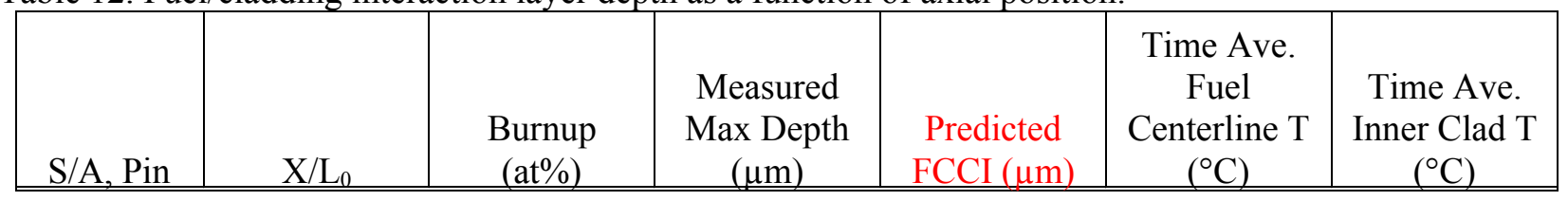




\begin{tabular}{|c|l|l|l|l|l|l|}
\hline \hline MFF5 & 0.03 & 6.7 & 0 & 0 & 532 & 414 \\
\cline { 2 - 7 } & 0.24 & 8.9 & 0 & 0 & 628 & 480 \\
\cline { 2 - 7 } & 0.48 & 9.8 & 0 & 20 & 712 & 556 \\
\cline { 2 - 7 } & 0.72 & 8.1 & 50.8 & 149 & 736 & 612 \\
\cline { 2 - 7 } & 0.96 & 4.8 & 25.4 & 84 & 709 & 635 \\
\hline \hline \multirow{4}{*}{$\begin{array}{l}\text { MFF3 } \\
\text { 193045 }\end{array}$} & 0.03 & 8.4 & 0 & 0 & 527 & 413 \\
\cline { 2 - 7 } & 0.25 & 11.3 & 0 & 0 & 619 & 475 \\
\cline { 2 - 7 } & 0.49 & 12.4 & 0 & 27 & 700 & 550 \\
\cline { 2 - 7 } & 0.74 & 9.1 & 76.2 & 138 & 682 & 604 \\
\cline { 2 - 7 } & 0.98 & 5.7 & 152.4 & 70 & & 615 \\
\hline
\end{tabular}

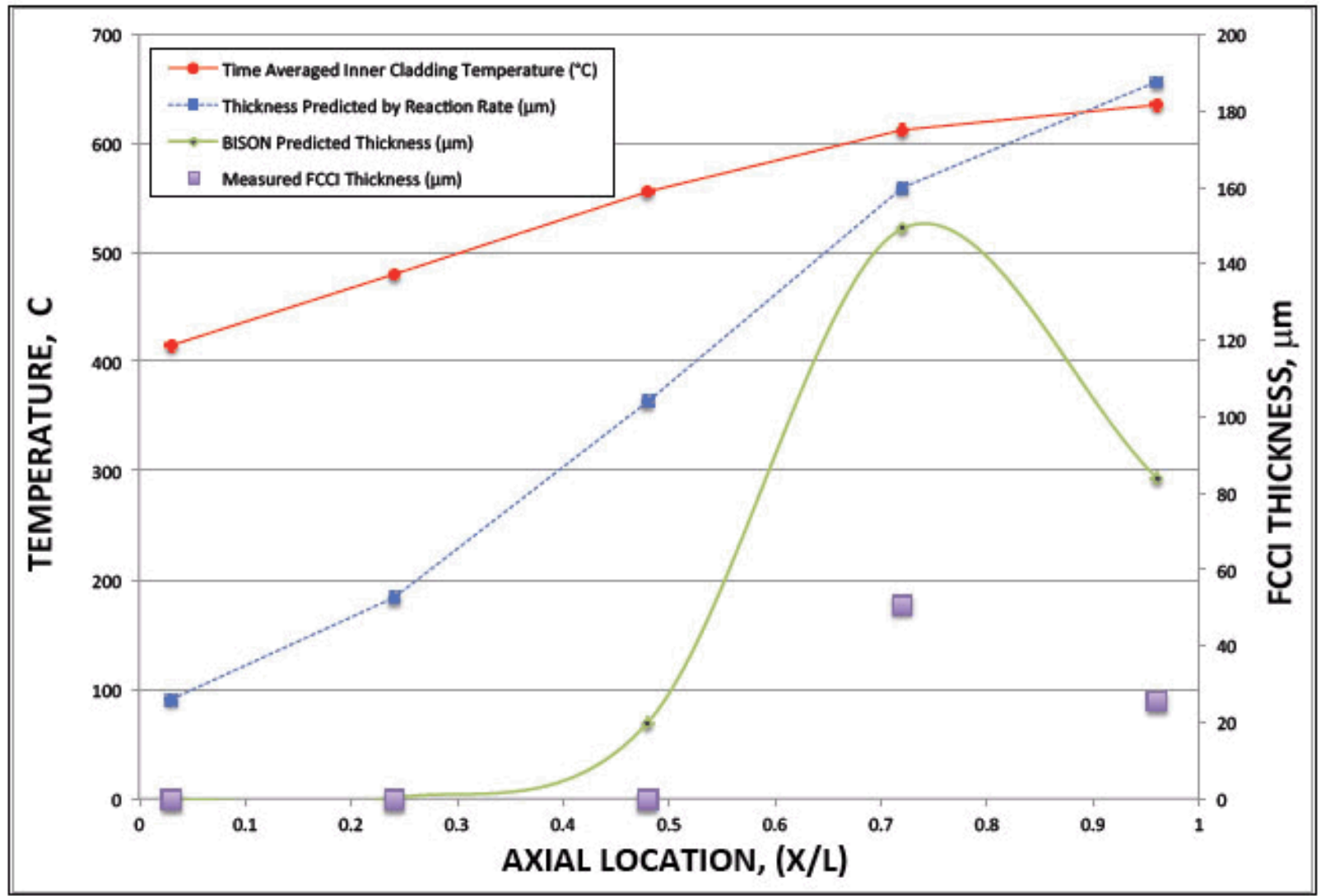

Figure 45. Fuel/cladding Chemical Interaction (FCCI) in MFF-5 Pin 195011. Shown are measured peak FCCI, predicted FCCI, and both time-averaged inner clad and fuel centerline temperatures. ${ }^{17}$

\subsection{Fuel Chemistry and Burnup}

A review of the as-run reactor physics calculations has already been presented earlier in this report. These calculations culminated with ORIGEN results as a function of axial position for the two fuel pins destructively examined, 193045 and 195011.These results are listed in Appendix A, Tables A-1 and A-2, of this report. 
Sections of the fuel pins taken near the axial locations used for metallography were taken and sent to the Analytical Laboratory for chemical and isotopic analysis. In this section we will review the results of these analyses with emphasis on how well the chemical analysis results matched with those calculated.

The fuel pin sections were dissolved and the fuel (HM plus Zr) estimated by: (1) Measuring the $\mathrm{Zr}$ content and assuming the $\mathrm{HM} / \mathrm{Zr}$ ratio to get the $\mathrm{HM}$ and total fuel mass, or (2) Measuring the cladding component concentrations ( $\mathrm{Fe}, \mathrm{Cr}, \mathrm{Mo}$ ), then using the cladding mass to estimate the fuel mass that would go with that length of cladding. These were only estimates as there were potential problems with oxidation of the fuel (oxidized U would not dissolve properly). However, the estimates could be used to test the accuracy in seeing how closely masses matched between the two estimation methods (cladding and $\mathrm{Zr}$ ) - they matched fairly well (within ten percent of one another).

All pertinent isotopes were measured including, ${ }^{233} \mathrm{U},{ }^{234} \mathrm{U},{ }^{235} \mathrm{U},{ }^{236} \mathrm{U},{ }^{238} \mathrm{U},{ }^{237} \mathrm{~Np},{ }^{239} \mathrm{Pu},{ }^{240} \mathrm{Pu},{ }^{241} \mathrm{~m} / \mathrm{Z}$, ${ }^{242} \mathrm{~m} / \mathrm{Z}$, and fission products ${ }^{85} \mathrm{Rb},{ }^{86} \mathrm{Sr},{ }^{87} \mathrm{Rb},{ }^{88} \mathrm{Sr},{ }^{89} \mathrm{Y},{ }^{99} \mathrm{Tc},{ }^{101} \mathrm{Ru},{ }^{102} \mathrm{Ru},{ }^{103} \mathrm{Rh},{ }^{104} \mathrm{Ru},{ }^{105} \mathrm{Pd},{ }^{106} \mathrm{Pd},{ }^{107} \mathrm{Pd}$, ${ }^{108} \mathrm{Pd},{ }^{109} \mathrm{Ag},{ }^{110} \mathrm{Pd},{ }^{111} \mathrm{Cd},{ }^{112} \mathrm{Cd},{ }^{114} \mathrm{Cd},{ }^{116} \mathrm{Cd},{ }^{133} \mathrm{Cs},{ }^{135} \mathrm{Cs},{ }^{136} \mathrm{Ba},{ }^{137} \mathrm{~m} / \mathrm{Z},{ }^{138} \mathrm{Ba},{ }^{139} \mathrm{La},{ }^{140} \mathrm{Ce},{ }^{141} \mathrm{Pr},{ }^{142} \mathrm{Ce},{ }^{143} \mathrm{Nd},{ }^{144} \mathrm{Nd},{ }^{145}$ $\mathrm{Nd},{ }^{146} \mathrm{Nd},{ }^{147} \mathrm{Sm},{ }^{148} \mathrm{~m} / \mathrm{Z},{ }^{149} \mathrm{Sm},{ }^{150} \mathrm{Nd},{ }^{152} \mathrm{Sm}$, and ${ }^{154} \mathrm{Sm}$.

' ${ }^{x x} \mathrm{~m} / \mathrm{Z}$ ' means of the isotopic mass ' $\mathrm{xxx}$ ' and for all atomic species with that isotopic mass, such as ${ }^{139} \mathrm{Nd}$ and ${ }^{139} \mathrm{Sm}$, combined, or ${ }^{241} \mathrm{Am}$ and ${ }^{241} \mathrm{Pu}$, combined. For these analyses they could not be differentiated without an additional separation process which was not done.

The fission product concentrations and their expected fission yields were then used to calculate the fuel burnup. Using those with long half-lives and those that can be easily differentiated from the other isotopes, the 'best' indicators of burnup for a fast neutron spectrum were chosen. Table 13 shows the burnups calculated for each of nine isotopes or isotope combinations. The final column is an average of the nine predicted burnups. Figure 46 shows these plotted for the two pins analyzed, one from MFF- 3 and one from MFF-5. Also plotted are burnups calculated from the ORIGEN calculations (see Appendix A) summing the heavy metals for each two-inch $(5.1 \mathrm{~cm})$ fuel section and computing [ $\left(\mathrm{HM}_{\text {as-built }}-\mathrm{HM}_{\text {ORIGEN }}\right) /$ $\left.\mathrm{HM}_{\mathrm{as}-b u i l t}\right]$. The calculated and measured burnups are in general agreement.

Figure 47 shows the ORIGEN predicted ${ }^{99} \mathrm{Tc}$ concentrations compared to the measured values. The comparison between the two is very good.

Table 13. Summary fuel burnups (heavy metal) computed from measured isotopic concentration measurements for isotopes thought to be most reliable for burnup determination.

\begin{tabular}{|c|c|c|c|c|c|c|}
\hline Pin & $\mathrm{X} / \mathrm{L}$ & $\mathrm{BU},{ }^{139} \mathrm{La}$ & $\mathrm{BU},{ }^{140} \mathrm{Ce}$ & $\mathrm{BU},{ }^{141} \mathrm{Pr}$ & $\mathrm{BU},{ }^{142} \mathrm{Ce}$ & $\mathrm{BU},{ }^{143} \mathrm{Nd}$ \\
\hline MFF-3: 193045 & 0.04 & 9.14 & 8.80 & 8.84 & 8.91 & 8.58 \\
\hline 193045 & 0.25 & 12.04 & 12.03 & 11.69 & 11.87 & 11.39 \\
\hline 193045 & 0.50 & 13.04 & 13.15 & 12.64 & 12.96 & 12.20 \\
\hline 193045 & 0.75 & 10.26 & 10.40 & 9.82 & 10.08 & 9.63 \\
\hline 193045 & 0.96 & 9.20 & 8.20 & 9.17 & 8.11 & 8.50 \\
\hline MFF-5: 195011 & 0.04 & 6.77 & 6.35 & 6.48 & 6.59 & 6.34 \\
\hline 195011 & 0.25 & 9.11 & 8.97 & 8.81 & 8.88 & 8.56 \\
\hline 195011 & 0.50 & 9.38 & 9.69 & 9.35 & 9.43 & 9.27 \\
\hline 195011 & 0.75 & 7.93 & 8.01 & 7.72 & 7.82 & 7.53 \\
\hline 195011 & 0.96 & 5.46 & 5.38 & 5.17 & 5.31 & 5.07 \\
\hline Pin & $\mathrm{X} / \mathrm{L}$ & $\mathrm{BU},{ }^{144} \mathrm{Nd}$ & $\begin{array}{c}\mathrm{BU}, \\
{ }^{143} \mathrm{Nd}+{ }^{144} \mathrm{Nd}\end{array}$ & $\begin{array}{c}\mathrm{BU} \\
{ }^{145} \mathrm{Nd}+{ }^{146} \mathrm{Nd}\end{array}$ & $\mathrm{BU},{ }^{99} \mathrm{Tc}$ & BU, Avg \\
\hline MFF-3: 193045 & 0.04 & & & & & \\
\hline
\end{tabular}




\begin{tabular}{|l|l|l|l|l|l|l|}
\hline & & 8.84 & & & & \\
\hline 193045 & 0.25 & 11.67 & 11.53 & 11.75 & 11.59 & 11.7 \\
\hline 193045 & 0.50 & 12.72 & 12.45 & 12.70 & 12.59 & 12.7 \\
\hline 193045 & 0.75 & 9.84 & 9.73 & 9.89 & 10.74 & 10.0 \\
\hline 193045 & 0.96 & 8.53 & 8.51 & 8.62 & 6.89 & 8.4 \\
\hline MFF-5: 195011 & 0.04 & 6.50 & 6.42 & 6.56 & 6.47 & 6.0 \\
\hline 195011 & 0.25 & 8.70 & 8.62 & 8.78 & 8.67 & 8.8 \\
\hline 195011 & 0.50 & 9.31 & 9.29 & 9.54 & 9.34 & 9.4 \\
\hline 195011 & 0.75 & 7.69 & 7.60 & 7.69 & 8.03 & 7.8 \\
\hline 195011 & 0.96 & 5.15 & 5.11 & 5.12 & 5.00 & 5.2 \\
\hline
\end{tabular}

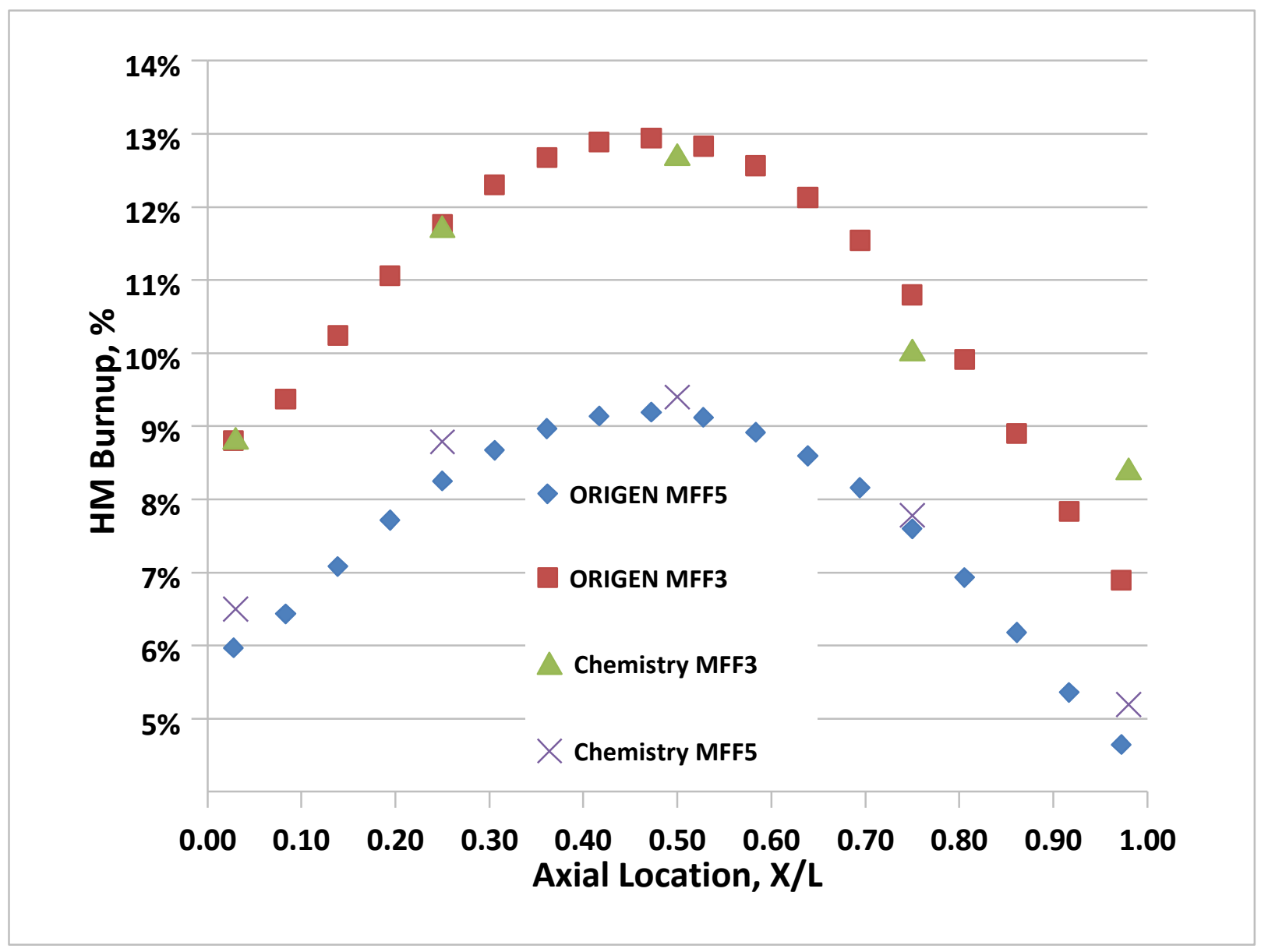

Figure 46. Heavy metal burnup as a function of axial location as calculated (ORIGEN) and measured (average of isotopic analyses). MFF-3 Pin 193045 and MFF-5 Pin 195011 are represented. 


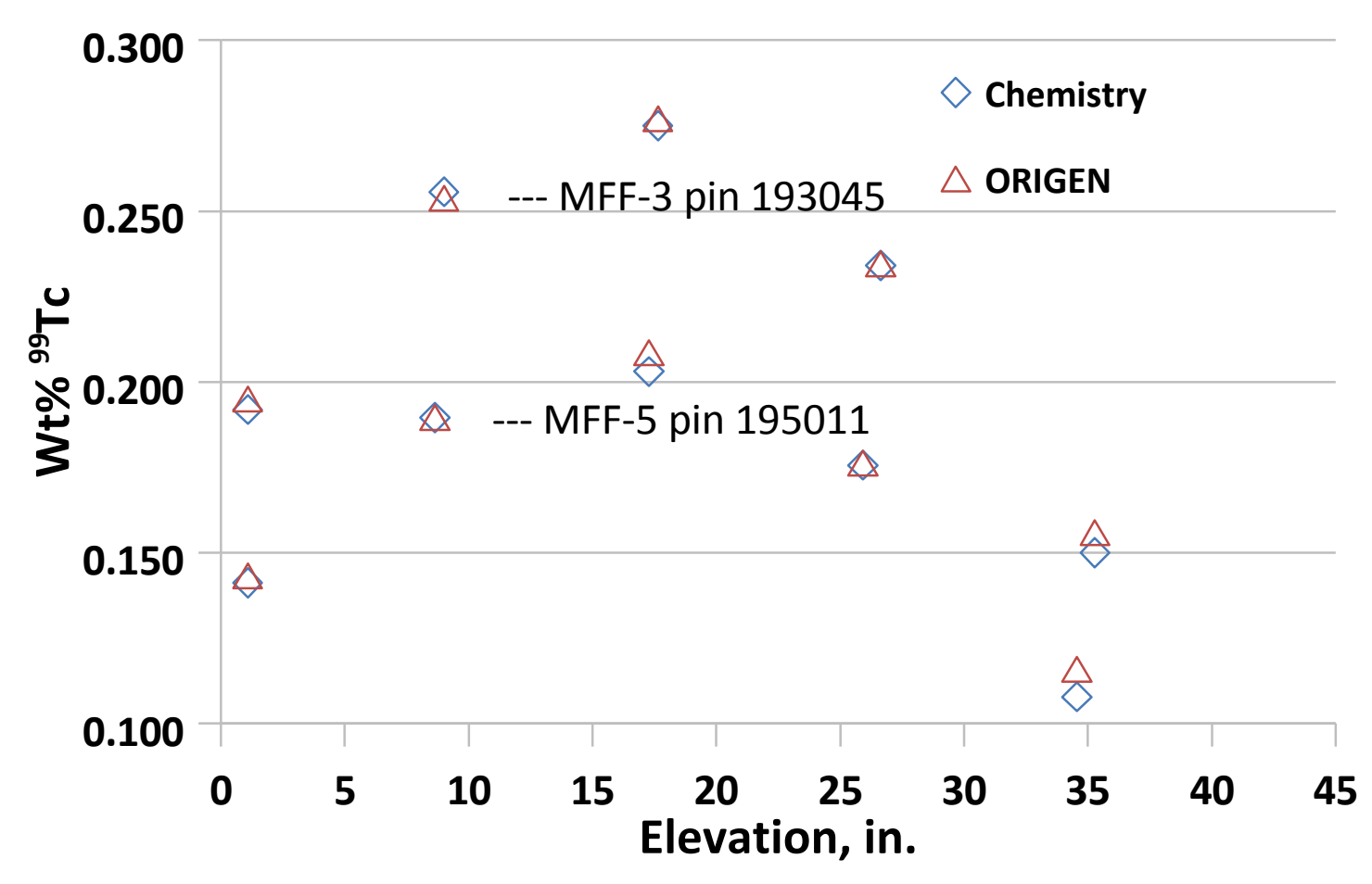

Figure 47. Tc-99 content after irradiation as a function of axial location as calculated (ORIGEN) and measured (Analytical Laboratory). MFF-3 Pin 193045 and MFF-5 Pin 195011 are represented.

\section{CONCLUSIONS}

1. Metallic fuel pins (U-10Zr/ HT9 cladding) from high-temperature FFTF driver fuel qualification tests MFF-3 and MFF-5 were examined using neutron radiography (axial expansion); gamma scanning; plenum gas pressure, volume, and composition; linear and spiral profilometry (cladding diameter); optical metallography and microhardness; isotopic and chemical analysis of fuel segments.

2. A full as-run neutronics analysis was completed tracking cycle-by-cycle the sodium and pin-by-pin cladding and fuel temperatures, fuel burnup and neutron exposure (fluence), and all of these as a function of axial position along the fuel pin pins. Assembly outlet temperature was also calculated as a function of reactor cycle.

3. The fuel in these experiments showed axial fuel growth less than observed in previous experiments, with the measured MFF-3 pins averaging 1.6\% and MFF-5 pins 3.6\% expansion. Previous tests showed averages of $7-9 \%$ expansion. While there are some indications as to the cause for this, namely the elevated fuel temperature in these tests, measurements of pins from two other FFTF assemblies may be done to help to discover the reason for this unexpected behavior.

4. The fission gas release was measured only for one pin from MFF-3 and one from MFF-5. The MFF-3 pin showed a gas release of only $61 \%$ which is low compared to other fuel tests, including MFF-5 which showed a release of 79\%, more like other tests, including IFR-1, another FFTF test.

5. Chemical/isotopic analyses of cross-sections of one fuel each from MFF-3 and MFF-5 correlated very well with ORIGEN calculations produced covering the axial length of the fuel column.

6. The cladding diameters as a function of axial position showed two peaks, especially in the MFF-3 
pins which were operated to higher neutron exposures. The peaks occurred at the top of the fuel column and slightly below the position of peak neutron flux, a little below the fuel column geometric center. The pin length showed little or no growth, indicating most of the strain should be related to creep. Therefore the two peaks may be related to irradiation creep (near the peak flux position) and thermal creep (at the top of the fuel column due to higher cladding temperature and FCCI clad wall thinning).

7. Axial growth of the pins was measured to estimate how much swelling may be present. There was enough apparent growth to explain the large diameter peak in the MFF-3 pin axial profile, but too much axial growth when compare to the smaller diameter increases in the MFF-5 pins. Immersion density of cladding would be required to address this issue.

8. Other pin performance characteristics looked very much like that exhibited by the fuel tests previously performed in EBR-II, on much shorter pins. 
5. REFERENCES 
INTENTIONALLY BLANK 
Appendix A

Fuel Pin ORIGEN Calculation 


\section{Appendix A}

\section{Fuel Pin ORIGEN Calculation}

The following Tables, A-1a through A-1m show an example of the results of a final isotopic prediction for one of the MFF-5 fuel pins, in this case Pin 195011, the MFF-5 pin that was destructively examined. The tables show the calculated elemental and isotopic compositions of eighteen 2-inch segments of the $\sim 36$-inch fuel column, assuming no axial growth. Note that they are normalized to a mass of 14.2 grams (heavy metal [HM] plus fission products [FP] - original $\mathrm{Zr}$ content not included) for each fuel segment. The individual isotopic compositions were decayed from the time of reactor shutdown to remove the assembly until 3/11/2011, the time when the examinations were being done.

This ORIGEN-based information was used to calculate HM burnup and compare these numbers with those calculated from the analytical chemistry results. The numbers were also helpful in estimating the expected activity of a given sample of the fuel, thereby allowing adequate preparation to minimize the exposure of laboratory personnel.

Tables A-2a through A-2m represent similar calculations for MFF-3 Pin 193045. 
Table A-1a. Composition (grams) in 2-inch fuel segment: ORIGEN calculation results for Pin195011, decayed to 3/11/2011.

\begin{tabular}{|c|c|c|c|c|c|c|c|c|c|c|c|c|c|c|c|c|c|c|}
\hline Position: & 1 & 3 & 5 & 7 & 9 & 11 & 13 & 15 & 17 & 19 & 21 & 23 & 25 & 27 & 29 & 31 & 33 & 35 \\
\hline HE 4 & 4.01E-06 & 4.41E-06 & $5.09 \mathrm{E}-06$ & $5.81 \mathrm{E}-06$ & $6.49 \mathrm{E}-06$ & 7.07E-06 & $7.50 \mathrm{E}-06$ & 7.76E-06 & $7.84 \mathrm{E}-06$ & 7.72E-06 & $7.42 \mathrm{E}-06$ & $6.96 \mathrm{E}-06$ & $6.36 \mathrm{E}-06$ & $5.66 \mathrm{E}-06$ & 4.90E-06 & 4.12E-06 & $3.41 \mathrm{E}-06$ & $2.89 \mathrm{E}-06$ \\
\hline $\mathrm{TH} 230$ & $0.00 \mathrm{E}+00$ & $0.00 \mathrm{E}+00$ & $0.00 \mathrm{E}+00$ & 4.93E-08 & $5.26 \mathrm{E}-08$ & $5.51 \mathrm{E}-08$ & 5.69E- 08 & $5.80 \mathrm{E}-08$ & $5.83 \mathrm{E}-08$ & $5.79 \mathrm{E}-08$ & 5.67E-08 & $5.48 \mathrm{E}-08$ & $5.22 \mathrm{E}-08$ & 4.89E-08 & $0.00 \mathrm{E}+00$ & $0.00 \mathrm{E}+00$ & $0.00 \mathrm{E}+00$ & $0.00 \mathrm{E}+00$ \\
\hline TH232 & $1.35 \mathrm{E}-07$ & $1.31 \mathrm{E}-07$ & $1.38 \mathrm{E}-07$ & $1.46 \mathrm{E}-07$ & $1.53 \mathrm{E}-07$ & $1.59 \mathrm{E}-07$ & 1.63E- 07 & 1.66E- 07 & 1.66E-07 & $1.65 \mathrm{E}-07$ & 1.62E-07 & $1.58 \mathrm{E}-07$ & $1.51 \mathrm{E}-07$ & 1.43E-07 & $1.33 \mathrm{E}-07$ & 1.22E-07 & 1.12E- 07 & 1.08E-07 \\
\hline PA231 & 7.05E-08 & $6.94 \mathrm{E}-08$ & $6.74 \mathrm{E}-08$ & $6.55 \mathrm{E}-08$ & $6.38 \mathrm{E}-08$ & $6.25 \mathrm{E}-08$ & $6.16 \mathrm{E}-08$ & $6.10 \mathrm{E}-08$ & $6.09 \mathrm{E}-08$ & $6.11 \mathrm{E}-08$ & $6.17 \mathrm{E}-08$ & $6.27 \mathrm{E}-08$ & $6.41 \mathrm{E}-08$ & $6.59 \mathrm{E}-08$ & $6.80 \mathrm{E}-08$ & 7.04E-08 & $7.30 \mathrm{E}-08$ & 7.50E-08 \\
\hline $\mathrm{U} 233$ & 1.44E-06 & $1.62 \mathrm{E}-06$ & 1.76E-06 & 1.87E-06 & $1.95 \mathrm{E}-06$ & $2.02 \mathrm{E}-06$ & $2.06 \mathrm{E}-06$ & $2.08 \mathrm{E}-06$ & $2.09 \mathrm{E}-06$ & $2.08 \mathrm{E}-06$ & $2.06 \mathrm{E}-06$ & $2.01 \mathrm{E}-06$ & $1.95 \mathrm{E}-06$ & $1.86 \mathrm{E}-06$ & $1.75 \mathrm{E}-06$ & $1.61 \mathrm{E}-06$ & 1.44E-06 & $1.23 \mathrm{E}-06$ \\
\hline U234 & $6.69 \mathrm{E}-04$ & $7.73 \mathrm{E}-04$ & 8.69E-04 & $9.55 \mathrm{E}-04$ & $1.03 \mathrm{E}-03$ & $1.08 \mathrm{E}-03$ & 1.13E-03 & 1.15E-03 & 1.16E-03 & 1.15E-03 & 1.12E-03 & $1.08 \mathrm{E}-03$ & 1.02E-03 & $9.45 \mathrm{E}-04$ & $8.60 \mathrm{E}-04$ & 7.64E-04 & $6.58 \mathrm{E}-04$ & 5.44E-04 \\
\hline $\mathrm{U} 235$ & $3.29 \mathrm{E}+00$ & $3.26 \mathrm{E}+00$ & $3.17 \mathrm{E}+00$ & $3.08 \mathrm{E}+00$ & $3.01 \mathrm{E}+00$ & $2.95 \mathrm{E}+00$ & $2.90 \mathrm{E}+00$ & $2.88 \mathrm{E}+00$ & $2.87 \mathrm{E}+00$ & $2.88 \mathrm{E}+00$ & $2.91 \mathrm{E}+00$ & $2.96 \mathrm{E}+00$ & $3.02 E+00$ & $3.10 \mathrm{E}+00$ & $3.20 \mathrm{E}+00$ & $3.31 \mathrm{E}+00$ & $3.42 \mathrm{E}+00$ & $3.51 \mathrm{E}+00$ \\
\hline U236 & $2.31 \mathrm{E}-01$ & $2.24 \mathrm{E}-01$ & 2.35E-01 & $2.49 \mathrm{E}-01$ & $2.61 \mathrm{E}-01$ & $2.71 \mathrm{E}-01$ & $2.78 \mathrm{E}-01$ & 2.83E-01 & $2.84 \mathrm{E}-01$ & 2.82E-01 & $2.77 \mathrm{E}-01$ & $2.69 \mathrm{E}-01$ & $2.58 \mathrm{E}-01$ & $2.44 \mathrm{E}-01$ & $2.27 \mathrm{E}-01$ & $2.09 \mathrm{E}-01$ & $1.91 \mathrm{E}-01$ & 1.85E-01 \\
\hline U237 & 1.68E-12 & $8 \mathrm{E}-12$ & $2 \mathrm{E}-12$ & $2.10 \mathrm{E}-12$ & $2.50 \mathrm{E}-12$ & $.86 \mathrm{E}-12$ & $15 \mathrm{E}-12$ & $33 \mathrm{E}-12$ & 3.38E-12 & 3.30E-12 & $3.09 \mathrm{E}-12$ & $2.78 \mathrm{E}-12$ & $2.38 \mathrm{E}-12$ & 1.95E-12 & 1.52E-12 & 1.14E-12 & $8.55 \mathrm{E}-13$ & $7.90 \mathrm{E}-13$ \\
\hline $\mathrm{U} 238$ & $9.43 \mathrm{E}+00$ & $9.40 \mathrm{E}+00$ & $9.37 \mathrm{E}+00$ & $9.33 \mathrm{E}+00$ & $9.30 \mathrm{E}+00$ & $9.28 \mathrm{E}+00$ & $9.26 \mathrm{E}+00$ & $9.25 \mathrm{E}+00$ & $9.25 \mathrm{E}+00$ & $9.25 \mathrm{E}+00$ & $9.26 \mathrm{E}+00$ & $9.28 \mathrm{E}+00$ & $9.31 \mathrm{E}+00$ & $9.34 \mathrm{E}+00$ & $9.38 \mathrm{E}+00$ & $9.42 \mathrm{E}+00$ & $9.46 \mathrm{E}+00$ & $9.50 \mathrm{E}+00$ \\
\hline $\mathrm{NP236}$ & $0.00 \mathrm{E}+00$ & $0.00 \mathrm{E}+00$ & $1.38 \mathrm{E}-07$ & 1.72E-07 & $2.05 \mathrm{E}-07$ & 2.33E- 07 & 2.55E- 07 & $2.68 \mathrm{E}-07$ & $2.72 \mathrm{E}-07$ & 2.66E-07 & $2.52 \mathrm{E}-07$ & $2.29 \mathrm{E}-07$ & 2.00E-07 & 1.67E-07 & $1.32 \mathrm{E}-07$ & $0.00 \mathrm{E}+00$ & $0.00 \mathrm{E}+00$ & $0.00 \mathrm{E}+00$ \\
\hline NP237 & $9.04 \mathrm{E}-03$ & $1.01 \mathrm{E}-02$ & $1.17 \mathrm{E}-02$ & 1.33E-02 & $1.48 \mathrm{E}-02$ & $1.60 \mathrm{E}-02$ & $1.69 \mathrm{E}-02$ & $1.74 \mathrm{E}-02$ & 1.76E-02 & $1.73 \mathrm{E}-02$ & 1.67E-02 & $1.58 \mathrm{E}-02$ & $1.45 \mathrm{E}-02$ & $1.30 \mathrm{E}-02$ & 1.13E-02 & 9.51E-03 & $7.75 \mathrm{E}-03$ & $6.29 \mathrm{E}-03$ \\
\hline PU238 & 4.49E-04 & $5.80 \mathrm{E}-04$ & 7.49E-04 & $9.28 \mathrm{E}-04$ & 1.10E-03 & $1.25 \mathrm{E}-03$ & $1.36 \mathrm{E}-03$ & 1.43E- 03 & $1.45 \mathrm{E}-03$ & 1.42E-03 & 1.34E-03 & $1.22 \mathrm{E}-03$ & $1.07 \mathrm{E}-03$ & 8.97E-04 & 7.16E-04 & $5.41 \mathrm{E}-04$ & 3.83E-04 & $2.58 \mathrm{E}-04$ \\
\hline PU239 & 2.52E-01 & $2.59 \mathrm{E}-01$ & 2.76E-01 & 2.94E- 01 & $3.10 \mathrm{E}-01$ & $3.22 \mathrm{E}-01$ & $3.31 \mathrm{E}-01$ & 3.37E-01 & 3.38E-01 & $3.36 \mathrm{E}-01$ & 3.30E-01 & $3.20 \mathrm{E}-01$ & 3.06E-01 & $2.89 \mathrm{E}-01$ & 2.68E-01 & 2.45E-01 & 2.21E-01 & 2.04E-01 \\
\hline PU240 & 7.64E- -03 & 7.03E- 03 & $7.78 \mathrm{E}-03$ & $8.87 \mathrm{E}-03$ & $9.94 \mathrm{E}-03$ & $1.09 \mathrm{E}-02$ & 1.16E-02 & 1.20E-02 & $1.22 \mathrm{E}-02$ & 1.19E-02 & 1.14E-02 & $1.07 \mathrm{E}-02$ & $9.62 \mathrm{E}-03$ & $8.44 \mathrm{E}-03$ & 7.17E- 03 & 5.91E-03 & 4.89E- 03 & 4.63E-03 \\
\hline PU241 & $5.43 \mathrm{E}-05$ & 4.77E- 05 & $5.57 \mathrm{E}-05$ & $6.79 \mathrm{E}-05$ & $8.08 \mathrm{E}-05$ & $9.25 \mathrm{E}-05$ & $1.02 E-04$ & $1.08 \mathrm{E}-04$ & 1.09E-04 & 1.07E-04 & $9.98 \mathrm{E}-05$ & $8.96 \mathrm{E}-05$ & 7.68E-05 & $6.30 \mathrm{E}-05$ & 4.92E-05 & 3.68E-05 & 2.76E-05 & 2.55E-05 \\
\hline PU242 & $1.60 \mathrm{E}-06$ & $1.36 \mathrm{E}-06$ & $1.68 \mathrm{E}-06$ & $2.21 \mathrm{E}-06$ & $2.81 \mathrm{E}-06$ & $3.39 \mathrm{E}-06$ & $3.87 \mathrm{E}-06$ & 4.17E-06 & 4.26E-06 & 4.11E- 06 & $3.76 \mathrm{E}-06$ & $3.24 \mathrm{E}-06$ & 2.62E-06 & $2.00 \mathrm{E}-06$ & 1.43E-06 & $9.57 \mathrm{E}-07$ & $6.46 \mathrm{E}-07$ & $5.74 \mathrm{E}-07$ \\
\hline AM241 & $8.29 \mathrm{E}-05$ & $7.28 \mathrm{E}-05$ & $8.49 \mathrm{E}-05$ & 1.04E-04 & $1.23 \mathrm{E}-04$ & $1.41 \mathrm{E}-04$ & $1.55 \mathrm{E}-04$ & $1.64 \mathrm{E}-04$ & 1.67E-04 & $1.62 \mathrm{E}-04$ & 1.52E-04 & $1.37 \mathrm{E}-04$ & $1.17 \mathrm{E}-04$ & $9.60 \mathrm{E}-05$ & $7.50 \mathrm{E}-05$ & $5.60 \mathrm{E}-05$ & 4.21E-05 & $3.89 \mathrm{E}-05$ \\
\hline CM242 & $0.00 \mathrm{E}+00$ & $0.00 \mathrm{E}+00$ & $0.00 \mathrm{E}+00$ & $0.00 \mathrm{E}+00$ & $1.45 \mathrm{E}-10$ & 1.74E-10 & $1.98 \mathrm{E}-10$ & 2.13E-10 & $2.17 \mathrm{E}-10$ & 2.10E-10 & $1.93 \mathrm{E}-10$ & $1.67 \mathrm{E}-10$ & $0.0 \mathrm{E}+00$ & $0.0 \mathrm{E}+00$ & $0.00 \mathrm{E}+00$ & $0.00 \mathrm{E}+00$ & $0.00 \mathrm{E}+00$ & $0.00 \mathrm{E}+00$ \\
\hline $\begin{array}{c}\text { SUM } \\
\text { HM } \\
\text { isotpes }\end{array}$ & $1.32 E+01$ & $1.32 \mathrm{E}+01$ & $1.31 \mathrm{E}+01$ & $1.30 \mathrm{E}+01$ & 1.29E+01 & 1.28E+01 & $1.28 \mathrm{E}+01$ & $1.28 \mathrm{E}+01$ & $1.28 \mathrm{E}+01$ & $1.28 \mathrm{E}+01$ & $1.28 \mathrm{E}+01$ & $1.29 \mathrm{E}+01$ & $1.29 \mathrm{E}+01$ & $1.30 E+01$ & $1.31 \mathrm{E}+01$ & $1.32 E+01$ & 1.33E+01 & $1.34 \mathrm{E}+01$ \\
\hline
\end{tabular}

Position=Segment location (midpoint of 2-in. segment) from bottom of fuel (BOF); sample wgt. 14.2g. 
Table A-1b. Composition (grams) in 2-inch fuel segment: ORIGEN calculation results for Pin195011, decayed to 3/11/2011.

\begin{tabular}{|c|c|c|c|c|c|c|c|c|c|c|c|c|c|c|c|c|c|c|}
\hline 6 & 1 & 3 & 5 & 7 & 9 & 11 & 13 & 15 & 17 & 19 & 21 & 23 & 25 & 27 & 29 & 31 & 33 & 35 \\
\hline HE & 4.01E-06 & $4.41 \mathrm{E}-06$ & 5.09E-06 & $5.81 \mathrm{E}-06$ & $6.49 \mathrm{E}-06$ & 7.07E-06 & 7.50E-06 & 7.76E-06 & 7.84E-06 & 7.72E- 06 & $7.42 \mathrm{E}-06$ & $6.96 \mathrm{E}-06$ & $6.36 \mathrm{E}-06$ & $5.66 \mathrm{E}-06$ & 4.90E-06 & 4.12E-06 & $3.41 \mathrm{E}-06$ & 2.89E-06 \\
\hline TH & 1.72E-07 & 1.73E-07 & 1.85E-07 & $1.97 \mathrm{E}-07$ & 2.08E-07 & 2.17E- 07 & 2.23E- 07 & $2.27 \mathrm{E}-07$ & 2.28E- 07 & $2.26 \mathrm{E}-07$ & $2.22 \mathrm{E}-07$ & 2.15E-07 & 2.05E-07 & 1.94E-07 & 1.80E-07 & $1.64 \mathrm{E}-07$ & 1.48E- 07 & 1.38E-07 \\
\hline PA & $7.08 \mathrm{E}-08$ & $6.97 \mathrm{E}-08$ & $6.78 \mathrm{E}-08$ & $6.59 \mathrm{E}-08$ & $6.43 \mathrm{E}-08$ & $6.31 \mathrm{E}-08$ & $6.22 \mathrm{E}-08$ & $6.16 \mathrm{E}-08$ & $6.15 \mathrm{E}-08$ & $6.17 \mathrm{E}-08$ & $6.23 \mathrm{E}-08$ & $6.33 \mathrm{E}-08$ & $6.46 \mathrm{E}-08$ & $6.63 \mathrm{E}-08$ & $6.84 \mathrm{E}-08$ & 7.07E-08 & 7.32E- 08 & $7.52 \mathrm{E}-08$ \\
\hline U & $1.30 \mathrm{E}+01$ & $1.29 \mathrm{E}+01$ & $1.28 \mathrm{E}+01$ & 1.27E+01 & $1.26 \mathrm{E}+01$ & $1.25 \mathrm{E}+01$ & $1.24 \mathrm{E}+01$ & 1.24E+01 & $1.24 \mathrm{E}+01$ & $1.24 \mathrm{E}+01$ & $1.25 \mathrm{E}+01$ & 1.25E+01 & $1.26 \mathrm{E}+01$ & $1.27 \mathrm{E}+01$ & $1.28 \mathrm{E}+01$ & $1.29 \mathrm{E}+01$ & $1.31 \mathrm{E}+01$ & 1.32E+01 \\
\hline NP & $9.04 \mathrm{E}-03$ & $1.01 \mathrm{E}-02$ & 1.17E-02 & 1.33E-02 & $1.48 \mathrm{E}-02$ & $1.60 \mathrm{E}-02$ & $1.69 \mathrm{E}-02$ & $1.74 \mathrm{E}-02$ & $1.76 \mathrm{E}-02$ & $1.73 \mathrm{E}-02$ & 1.67E-02 & $1.58 \mathrm{E}-02$ & 1.45E-02 & $1.30 \mathrm{E}-02$ & 1.13E-02 & $9.51 \mathrm{E}-03$ & $7.75 \mathrm{E}-03$ & $6.29 \mathrm{E}-03$ \\
\hline PU & $2.60 \mathrm{E}-01$ & 2.66E-01 & 2.84E-01 & $3.04 \mathrm{E}-01$ & $3.21 \mathrm{E}-01$ & $3.35 \mathrm{E}-01$ & $3.45 \mathrm{E}-01$ & 3.50E-01 & $3.52 \mathrm{E}-01$ & $3.49 \mathrm{E}-01$ & 3.43E-01 & $3.32 \mathrm{E}-01$ & $3.17 \mathrm{E}-01$ & $2.98 \mathrm{E}-01$ & 2.76E-01 & $2.51 \mathrm{E}-01$ & $2.27 \mathrm{E}-01$ & 2.09E-01 \\
\hline AM & $8.29 \mathrm{E}-05$ & $7.28 \mathrm{E}-05$ & $8.49 \mathrm{E}-05$ & $1.04 \mathrm{E}-04$ & 1.23E-04 & 1.41E-04 & $1.55 \mathrm{E}-04$ & 1.64E-04 & 1.67E-04 & 1.62E-04 & 1.52E-04 & $1.37 \mathrm{E}-04$ & 1.17E-04 & $9.61 \mathrm{E}-05$ & $7.51 \mathrm{E}-05$ & $5.60 \mathrm{E}-05$ & 4.21E-05 & 3.89E-05 \\
\hline $\mathrm{CM}$ & $0.00 \mathrm{E}+00$ & $0.00 \mathrm{E}+00$ & $0.00 \mathrm{E}+00$ & $0.00 \mathrm{E}+00$ & 1.48E-09 & $1.91 \mathrm{E}-09$ & $2.28 \mathrm{E}-09$ & $2.52 \mathrm{E}-09$ & $2.59 \mathrm{E}-09$ & $2.48 \mathrm{E}-09$ & $2.20 \mathrm{E}-09$ & $1.81 \mathrm{E}-09$ & 1.38E-09 & $0.00 \mathrm{E}+00$ & $0.00 E+00$ & $0.00 \mathrm{E}+00$ & $0.00 \mathrm{E}+00$ & $0.00 E+00$ \\
\hline $\begin{array}{l}\text { SUM HM } \\
\text { elements }\end{array}$ & 1.32E+01 & 1. $32 \mathrm{E}+01$ & $1.31 \mathrm{E}+01$ & $1.30 \mathrm{E}+01$ & $1.29 \mathrm{E}+01$ & $1.28 \mathrm{E}+01$ & $1.28 \mathrm{E}+01$ & $1.28 \mathrm{E}+01$ & $1.28 \mathrm{E}+01$ & $1.28 \mathrm{E}+01$ & $1.28 \mathrm{E}+01$ & $1.29 \mathrm{E}+01$ & 1.29E+01 & $1.30 \mathrm{E}+01$ & $1.31 \mathrm{E}+01$ & $1.32 E+01$ & 1.33E+01 & $1.34 \mathrm{E}+01$ \\
\hline H3 & 7.93E-07 & $8.48 \mathrm{E}-07$ & 9.25E-07 & $9.98 \mathrm{E}-07$ & $1.06 \mathrm{E}-06$ & 1.11E-06 & 1.14E-06 & 1.16E-06 & 1.17E- 06 & 1.16E-06 & $1.14 \mathrm{E}-06$ & 1.10E-06 & 1.05E-06 & 9.85E-07 & 9.07E-07 & $8.19 \mathrm{E}-07$ & 7.24E- 07 & $6.40 \mathrm{E}-07$ \\
\hline LI 6 & 1.18E-08 & 1.26E-08 & 1.37E-08 & $1.47 \mathrm{E}-08$ & $1.56 \mathrm{E}-08$ & $1.62 \mathrm{E}-08$ & 1.67E-08 & 1.70E-08 & $1.71 \mathrm{E}-08$ & $1.70 \mathrm{E}-08$ & 1.66E-08 & 1.61E-08 & $1.54 \mathrm{E}-08$ & 1.45E-08 & 1.34E- 08 & $1.21 \mathrm{E}-08$ & $1.08 \mathrm{E}-08$ & $9.58 \mathrm{E}-09$ \\
\hline GE 72 & 1.78E-06 & 1.94E-06 & $2.13 \mathrm{E}-06$ & $2.30 \mathrm{E}-06$ & $2.44 \mathrm{E}-06$ & $2.56 \mathrm{E}-06$ & $2.64 \mathrm{E}-06$ & $2.69 \mathrm{E}-06$ & $2.70 \mathrm{E}-06$ & $2.68 \mathrm{E}-06$ & $2.62 \mathrm{E}-06$ & $2.54 \mathrm{E}-06$ & $2.42 \mathrm{E}-06$ & $2.27 \mathrm{E}-06$ & 2.09E- 06 & $1.88 \mathrm{E}-06$ & 1.65E-06 & $1.44 \mathrm{E}-06$ \\
\hline GE 73 & 4.48E-06 & 4.81E-06 & 5.25E-06 & $5.65 \mathrm{E}-06$ & $5.99 \mathrm{E}-06$ & $6.25 \mathrm{E}-06$ & $6.44 \mathrm{E}-06$ & $6.55 \mathrm{E}-06$ & $6.58 \mathrm{E}-06$ & $6.53 \mathrm{E}-06$ & $6.41 \mathrm{E}-06$ & $6.21 \mathrm{E}-06$ & $5.93 \mathrm{E}-06$ & $5.58 \mathrm{E}-06$ & $5.15 \mathrm{E}-06$ & 4.66E-06 & 4.12E-06 & 3.63E-06 \\
\hline GE 74 & $8.91 \mathrm{E}-06$ & 9.55E-06 & 1.04E-05 & 1.13E-05 & $1.20 \mathrm{E}-05$ & 1.25E-05 & $1.29 \mathrm{E}-05$ & $1.31 \mathrm{E}-05$ & $1.32 \mathrm{E}-05$ & $1.31 \mathrm{E}-05$ & $1.28 \mathrm{E}-05$ & $1.24 \mathrm{E}-05$ & 1.18E-05 & $1.11 \mathrm{E}-05$ & 1.02E-05 & $9.23 \mathrm{E}-06$ & $8.15 \mathrm{E}-06$ & 7.18E-06 \\
\hline AS 75 & $1.51 \mathrm{E}-05$ & $1.61 \mathrm{E}-05$ & $1.75 \mathrm{E}-05$ & $1.88 \mathrm{E}-05$ & 2.00E-05 & 2.08E-05 & 2.15E-05 & $2.18 \mathrm{E}-05$ & 2.19E-05 & $2.18 \mathrm{E}-05$ & $2.14 \mathrm{E}-05$ & 2.07E-05 & $1.98 \mathrm{E}-05$ & $1.86 \mathrm{E}-05$ & $1.72 \mathrm{E}-05$ & $1.56 \mathrm{E}-05$ & $1.38 \mathrm{E}-05$ & $1.22 \mathrm{E}-05$ \\
\hline GE 76 & $3.51 \mathrm{E}-05$ & $3.74 \mathrm{E}-05$ & 4.07E-05 & 4.39E-05 & 4.65E-05 & 4.86E-05 & $5.01 \mathrm{E}-05$ & $5.10 \mathrm{E}-05$ & $5.12 \mathrm{E}-05$ & 5.09E-05 & 4.99E-05 & 4.83E-05 & 4.61E-05 & 4.33E-05 & 3.99E-05 & $3.61 \mathrm{E}-05$ & $3.20 \mathrm{E}-05$ & 2.84E-05 \\
\hline SE 76 & 2.77E-07 & $3.42 \mathrm{E}-07$ & 4.20E-07 & 4.97E-07 & 5.67E-07 & $6.26 \mathrm{E}-07$ & $6.69 \mathrm{E}-07$ & $6.95 \mathrm{E}-07$ & 7.02E-07 & $6.91 \mathrm{E}-07$ & $6.62 \mathrm{E}-07$ & $6.16 \mathrm{E}-07$ & 5.57E- 07 & 4.85E-07 & 4.07E-07 & 3.26E-07 & 2.47E- 07 & $1.80 \mathrm{E}-07$ \\
\hline SE 77 & $6.99 \mathrm{E}-05$ & 7.41E-05 & $8.04 \mathrm{E}-05$ & $8.63 \mathrm{E}-05$ & $9.14 \mathrm{E}-05$ & $9.54 \mathrm{E}-05$ & $9.82 \mathrm{E}-05$ & $9.98 \mathrm{E}-05$ & $1.00 \mathrm{E}-04$ & $9.96 \mathrm{E}-05$ & $9.77 \mathrm{E}-05$ & $9.47 \mathrm{E}-05$ & $9.05 \mathrm{E}-05$ & $8.52 \mathrm{E}-05$ & $7.88 \mathrm{E}-05$ & 7.14E-05 & $6.35 \mathrm{E}-05$ & $5.66 \mathrm{E}-05$ \\
\hline SE 78 & 1.42E-04 & 1.51E-04 & 1.64E-04 & 1.76E-04 & 1.87E-04 & $1.96 \mathrm{E}-04$ & $2.02 \mathrm{E}-04$ & $2.05 \mathrm{E}-04$ & $2.06 \mathrm{E}-04$ & $2.05 \mathrm{E}-04$ & $2.01 \mathrm{E}-04$ & $1.94 \mathrm{E}-04$ & 1.85E-04 & $1.74 \mathrm{E}-04$ & 1.61E-04 & $1.45 \mathrm{E}-04$ & 1.29E-04 & $1.14 \mathrm{E}-04$ \\
\hline SE 79 & $2.16 \mathrm{E}-04$ & $2.30 \mathrm{E}-04$ & $2.51 \mathrm{E}-04$ & $2.71 \mathrm{E}-04$ & $2.88 \mathrm{E}-04$ & $3.01 \mathrm{E}-04$ & $3.10 \mathrm{E}-04$ & 3.16E-04 & $3.17 \mathrm{E}-04$ & $3.15 \mathrm{E}-04$ & $3.09 \mathrm{E}-04$ & $2.99 \mathrm{E}-04$ & $2.85 \mathrm{E}-04$ & 2.67E-04 & $2.47 \mathrm{E}-04$ & $2.23 \mathrm{E}-04$ & $1.97 \mathrm{E}-04$ & 1.74E-04 \\
\hline
\end{tabular}




\begin{tabular}{|c|c|c|c|c|c|c|c|c|c|c|c|c|c|c|c|c|c|c|}
\hline BR 79 & $4.62 \mathrm{E}-08$ & $4.94 \mathrm{E}-08$ & $5.39 \mathrm{E}-08$ & $5.81 \mathrm{E}-08$ & $6.17 \mathrm{E}-08$ & $6.45 \mathrm{E}-08$ & $6.65 \mathrm{E}-08$ & $6.76 \mathrm{E}-08$ & $6.80 \mathrm{E}-08$ & $6.75 \mathrm{E}-08$ & $6.61 \mathrm{E}-08$ & $6.40 \mathrm{E}-08$ & $6.10 \mathrm{E}-08$ & $5.73 \mathrm{E}-08$ & $5.28 \mathrm{E}-08$ & $4.77 \mathrm{E}-08$ & 4.22E-08 & $3.72 \mathrm{E}-08$ \\
\hline SE 80 & $4.63 \mathrm{E}-04$ & $4.91 \mathrm{E}-04$ & 5.34E-04 & $5.75 \mathrm{E}-04$ & $6.10 \mathrm{E}-04$ & $6.37 \mathrm{E}-04$ & $6.56 \mathrm{E}-04$ & $6.67 \mathrm{E}-04$ & $6.70 \mathrm{E}-04$ & $6.66 \mathrm{E}-04$ & $6.53 \mathrm{E}-04$ & $6.32 \mathrm{E}-04$ & $6.04 \mathrm{E}-04$ & $5.67 \mathrm{E}-04$ & $5.24 \mathrm{E}-04$ & 4.74E-04 & $4.20 \mathrm{E}-04$ & $3.74 \mathrm{E}-04$ \\
\hline BR 81 & 7.36E-04 & $7.82 \mathrm{E}-04$ & $8.49 \mathrm{E}-04$ & $9.12 \mathrm{E}-04$ & $9.65 \mathrm{E}-04$ & $1.01 \mathrm{E}-03$ & $1.04 \mathrm{E}-03$ & $1.05 \mathrm{E}-03$ & $1.06 \mathrm{E}-03$ & $1.05 \mathrm{E}-03$ & $1.03 \mathrm{E}-03$ & $9.99 \mathrm{E}-04$ & $9.56 \mathrm{E}-04$ & $9.00 \mathrm{E}-04$ & $8.32 \mathrm{E}-04$ & $7.55 \mathrm{E}-04$ & $6.71 \mathrm{E}-04$ & $5.97 \mathrm{E}-04$ \\
\hline SE 82 & $1.07 \mathrm{E}-03$ & $1.14 \mathrm{E}-03$ & $1.24 \mathrm{E}-03$ & $1.34 \mathrm{E}-03$ & 1.42E-03 & $1.49 \mathrm{E}-03$ & $1.53 \mathrm{E}-03$ & $1.56 \mathrm{E}-03$ & $1.56 \mathrm{E}-03$ & $1.55 \mathrm{E}-03$ & $1.52 \mathrm{E}-03$ & 1.47E-03 & $1.41 \mathrm{E}-03$ & $1.32 \mathrm{E}-03$ & $1.22 \mathrm{E}-03$ & 1.10E-03 & $9.76 \mathrm{E}-04$ & 8.64E-04 \\
\hline
\end{tabular}


Table A-1c. Composition (grams) in 2-inch fuel segment: ORIGEN calculation results for Pin195011, decayed to 3/11/2011.

\begin{tabular}{|c|c|c|c|c|c|c|c|c|c|c|c|c|c|c|c|c|c|c|}
\hline Position: & 1 & 3 & 5 & 7 & 9 & 11 & 13 & 15 & 17 & 19 & 21 & 23 & 25 & 27 & 29 & 31 & 33 & 35 \\
\hline KR 82 & $1.70 \mathrm{E}-05$ & $2.07 E-05$ & $2.53 \mathrm{E}-05$ & $2.99 E-05$ & $3.40 E=-05$ & $3.74 E-05$ & $4.00 E-05$ & $4.15 E-05$ & $4.19 \mathrm{E}-05$ & $4.13 \mathrm{E}-05$ & $3.95 \mathrm{E}-05$ & $3.69 E-05$ & $3.34 \mathrm{E}-05$ & $2.92 \mathrm{E}-05$ & $2.45 E-05$ & $1.97 E-05$ & $1.51 \mathrm{E}-05$ & $1.11 E-05$ \\
\hline KR 83 & $1.84 \mathrm{E}-03$ & $1.95 E-03$ & $2.12 E-03$ & $2.27 E-03$ & $2.41 E-03$ & $2.51 \mathrm{E}-03$ & $2.58 \mathrm{E}-03$ & $2.63 \mathrm{E}-03$ & $2.64 \mathrm{E}-03$ & $2.62 \mathrm{E}-03$ & $2.57 \mathrm{E}-03$ & $2.49 \mathrm{E}-03$ & $2.38 \mathrm{E}-03$ & $2.24 \mathrm{E}-03$ & $2.08 E-03$ & $1.88 \mathrm{E}-03$ & $1.68 \mathrm{E}-03$ & $1.49 \mathrm{E}-03$ \\
\hline KR 84 & $3.54 \mathrm{E}-03$ & $3.78 \mathrm{E}-03$ & $4.12 E-03$ & 4.44E- -03 & $4.72 E-03$ & $4.94 \mathrm{E}-03$ & $5.09 E-03$ & $5.18 \mathrm{E}-03$ & $5.21 \mathrm{E}-03$ & $5.17 \mathrm{E}-03$ & $5.07 E-03$ & $4.90 \mathrm{E}-03$ & $4.67 \mathrm{E}-03$ & $4.38 \mathrm{E}-03$ & $4.04 E-03$ & $3.64 \mathrm{E}-03$ & $3.22 \mathrm{E}-03$ & $2.85 \mathrm{E}-03$ \\
\hline KR 85 & $2.49 \mathrm{E}-04$ & $2.65 \mathrm{E}-04$ & $2.89 E-04$ & $3.11 E-04$ & $3.30 \mathrm{E}-04$ & $3.45 E-04$ & 3.56E-04 & $3.62 E-04$ & 3.64E- 04 & $3.61 \mathrm{E}-04$ & $3.54 E-04$ & $3.43 E-04$ & $.27 \mathrm{E}-04$ & $3.07 E-04$ & $2.83 E-04$ & $2.56 \mathrm{E}-04$ & $2.27 E-04$ & $2.01 \mathrm{E}-04$ \\
\hline RB 85 & $3.99 \mathrm{E}-03$ & $4.23 \mathrm{E}-03$ & $4.59 E-03$ & $4.94 E-03$ & $5.24 \mathrm{E}-03$ & $5.47 \mathrm{E}-03$ & $5.63 \mathrm{E}-03$ & $\begin{array}{l}5.73 \mathrm{E}-03 \\
\end{array}$ & $5.76 E-03$ & $5.72 \mathrm{E}-03$ & $5.61 \mathrm{E}-03$ & $5.43 \mathrm{E}-03$ & $5.19 \mathrm{E}-03$ & $4.88 \mathrm{E}-03$ & $4.50 \mathrm{E}-03$ & $4.08 E-03$ & $3.62 \mathrm{E}-03$ & $3.23 \mathrm{E}-03$ \\
\hline KR 86 & $6.60 \mathrm{E}-03$ & $7.01 E-03$ & $7.62 E-03$ & $8.21 \mathrm{E}-03$ & $8.70 \mathrm{E}-03$ & $9.09 E-03$ & $9.37 E-03$ & $9.53 \mathrm{E}-03$ & $9.58 \mathrm{E}-03$ & $9.51 \mathrm{E}-03$ & $9.32 E-03$ & $9.02 E-03$ & $8.62 E-03$ & $8.10 \mathrm{E}-03$ & $7.47 E-03$ & $6.76 \mathrm{E}-03$ & $5.99 \mathrm{E}-03$ & $5.33 \mathrm{E}-03$ \\
\hline RB 86 & $0.00 E+00$ & $0.00 E+00$ & $0.00 E+00$ & $0.00 E+00$ & $0.00 E+00$ & $0.00 E+00$ & $0.00 E+00$ & $0.00 E+00$ & $0.00 E+00$ & $0.00 E+00$ & $0.00 E+00$ & $0.00 E+00$ & $0.00 E+00$ & $0.00 E+00$ & $0.00 E+00$ & $0.00 E+00$ & $0.00 E+00$ & $0.00 E+00$ \\
\hline SR 86 & $3.72 E-05$ & $4.56 \mathrm{E}-05$ & $5.58 \mathrm{E}-05$ & $6.61 \mathrm{E}-05$ & $7.54 \mathrm{E}-05$ & $8.32 E-05$ & $8.89 E-05$ & $9.24 \mathrm{E}-05$ & $9.34 \mathrm{E}-05$ & $9.19 \mathrm{E}-05$ & $8.80 E-05$ & $8.19 E-05$ & $7.40 \mathrm{E}-05$ & $6.45 E-05$ & $5.41 E-05$ & $4.33 E-05$ & $3.30 \mathrm{E}-05$ & $\begin{array}{r}2.42 \mathrm{E}-05 \\
\end{array}$ \\
\hline RB 87 & $8.40 \mathrm{E}-03$ & $8.92 E-03$ & $9.70 \mathrm{E}-03$ & $1.04 E-02$ & $1.11 \mathrm{E}-02$ & $1.16 \mathrm{E}-02$ & 1.19E-02 & $1.21 \mathrm{E}-02$ & $1.22 E-02$ & $1.21 \mathrm{E}-02$ & 1.19E-02 & 1.15E-02 & 1. $10 \mathrm{E}-02$ & $1.03 E-02$ & $9.51 E-03$ & $8.60 \mathrm{E}-03$ & $7.63 \mathrm{E}-03$ & $6.79 \mathrm{E}-03$ \\
\hline SR 87 & $1.75 \mathrm{E}-07$ & $2.15 E-07$ & $2.69 E-07$ & $3.28 \mathrm{E}-07$ & $3.84 \mathrm{E}-07$ & $4.33 \mathrm{E}-07$ & $4.71 E-07$ & 4.94E -07 & $5.01 \mathrm{E}-07$ & $4.91 \mathrm{E}-07$ & $4.65 \mathrm{E}-07$ & $4.25 E-07$ & $3.75 E-07$ & $3.19 \mathrm{E}-07$ & $2.60 E-07$ & $2.04 E-07$ & $1.55 \mathrm{E}-07$ & $1.17 \mathrm{E}-07$ \\
\hline SR 88 & $1.24 \mathrm{E}-02$ & $1.31 \mathrm{E}-02$ & $1.43 \mathrm{E}-02$ & $1.54 \mathrm{E}-02$ & $1.63 \mathrm{E}-02$ & $1.70 \mathrm{E}-02$ & $1.75 \mathrm{E}-02$ & $1.78 \mathrm{E}-02$ & $1.79 E-02$ & $1.78 \mathrm{E}-02$ & $1.74 \mathrm{E}-02$ & $1.69 \mathrm{E}-02$ & $1.61 \mathrm{E}-02$ & $1.52 \mathrm{E}-02$ & 1.40E- -22 & $1.27 \mathrm{E}-02$ & $1.12 \mathrm{E}-02$ & $9.99 \mathrm{E}-03$ \\
\hline SR 89 & $1.37 E-42$ & $1.37 E-42$ & $1.50 \mathrm{E}-42$ & $1.62 E-42$ & $1.75 E-42$ & $1.75 E-42$ & $1.87 E-42$ & $1.87 E-42$ & $1.87 \mathrm{E}-42$ & $1.87 E-42$ & $1.87 E-42$ & $1.75 E-42$ & $1.75 E-42$ & $1.62 E-42$ & 1.50E- 42 & 1.37E-42 & $1.25 E-42$ & 1.12E- 42 \\
\hline Y 89 & $1.56 \mathrm{E}-02$ & $1.66 \mathrm{E}-02$ & $1.80 E-02$ & $1.94 E-02$ & $\begin{array}{l}2.06 \mathrm{E}-02 \\
\end{array}$ & $2.15 E-02$ & $2.21 \mathrm{E}-02$ & $\begin{array}{r}2.25 E-02 \\
\end{array}$ & $2.26 \mathrm{E}-02$ & $2.24 \mathrm{E}-02$ & $\begin{array}{r}2.20 \mathrm{E}-02 \\
\end{array}$ & $2.13 E-02$ & $2.04 E-02$ & $1.91 \mathrm{E}-02$ & $1.77 E-02$ & $1.60 \mathrm{E}-02$ & $1.42 \mathrm{E}-02$ & $1.26 \mathrm{E}-02$ \\
\hline SR 90 & 1.17E- -02 & $1.24 \mathrm{E}-02$ & $1.35 E-02$ & $1.45 E-02$ & $1.54 \mathrm{E}-02$ & $1.61 \mathrm{E}-02$ & $1.65 \mathrm{E}-02$ & $1.68 \mathrm{E}-02$ & $1.69 \mathrm{E}-02$ & $1.68 \mathrm{E}-02$ & $1.65 \mathrm{E}-02$ & 1.59E-02 & $1.52 \mathrm{E}-02$ & $1.43 \mathrm{E}-02$ & $1.32 E-02$ & 1.19E-02 & $1.06 \mathrm{E}-02$ & $9.44 \mathrm{E}-03$ \\
\hline Y90 & $2.93 \mathrm{E}-06$ & $3.11 E-06$ & $3.38 E-06$ & $3.63 \mathrm{E}-06$ & $3.85 \mathrm{E}-06$ & $4.02 E-06$ & $4.15 E-06$ & 4.22E- -06 & $4.24 \mathrm{E}-06$ & $4.21 \mathrm{E}-06$ & 4.13E-06 & $3.99 E-06$ & $3.81 \mathrm{E}-06$ & $3.59 \mathrm{E}-06$ & $3.31 E-06$ & $3.00 E-06$ & $2.66 \mathrm{E}-06$ & $2.37 \mathrm{E}-06$ \\
\hline ZR 90 & 7.37E-03 & $7.82 E-03$ & $8.50 \mathrm{E}-03$ & $9.15 E-03$ & $9.70 \mathrm{E}-03$ & $1.01 E-02$ & $1.05 E-02$ & $1.06 \mathrm{E}-02$ & $1.07 E-02$ & $1.06 \mathrm{E}-02$ & $1.04 \mathrm{E}-02$ & $1.01 E-02$ & $9.60 \mathrm{E}-03$ & $9.02 E-03$ & $8.32 E-03$ & $7.53 \mathrm{E}-03$ & $6.68 \mathrm{E}-03$ & $5.95 \mathrm{E}-03$ \\
\hline Y 91 & $4.34 E-37$ & $4.62 E-37$ & $4.99 E-37$ & $5.33 E-37$ & $5.61 E-37$ & $5.82 E-37$ & $5.98 E-37$ & $6.06 \mathrm{E}-37$ & $6.09 E-37$ & $6.06 E-37$ & $5.97 \mathrm{E}-37$ & $5.82 E-37$ & $5.60 \mathrm{E}-37$ & $5.31 E-37$ & $4.95 E-37$ & 4.53E-37 & $4.06 E-37$ & $3.63 E-37$ \\
\hline ZR 91 & $1.98 \mathrm{E}-02$ & $2.10 \mathrm{E}-02$ & $2.28 \mathrm{E}-02$ & $2.46 \mathrm{E}-02$ & $2.60 \mathrm{E}-02$ & $2.72 \mathrm{E}-02$ & $2.80 \mathrm{E}-02$ & $2.85 \mathrm{E}-02$ & $2.86 \mathrm{E}-02$ & $2.84 \mathrm{E}-02$ & $\begin{array}{l}2.79 \mathrm{E}-02 \\
\end{array}$ & $2.70 \mathrm{E}-02$ & $2.58 \mathrm{E}-02$ & $2.42 \mathrm{E}-02$ & $2.24 \mathrm{E}-02$ & $2.02 E-02$ & $1.80 \mathrm{E}-02$ & $1.60 \mathrm{E}-02$ \\
\hline ZR 92 & $2.09 \mathrm{E}-02$ & $2.22 E-02$ & $2.41 \mathrm{E}-02$ & $2.60 \mathrm{E}-02$ & $\begin{array}{l}2.76 \mathrm{E}-02 \\
\end{array}$ & $2.88 \mathrm{E}-02$ & $2.97 \mathrm{E}-02$ & $3.02 E-02$ & $3.04 E-02$ & $3.02 E-02$ & $2.96 \mathrm{E}-02$ & $2.86 \mathrm{E}-02$ & $2.73 \mathrm{E}-02$ & $2.56 \mathrm{E}-02$ & $2.37 E-02$ & 2.14E-02 & $1.89 \mathrm{E}-02$ & $1.68 \mathrm{E}-02$ \\
\hline ZR 93 & $2.29 \mathrm{E}-02$ & $2.44 E-02$ & $2.65 \mathrm{E}-02$ & $2.86 \mathrm{E}-02$ & $3.03 E-02$ & $3.17 E-02$ & $3.27 \mathrm{E}-02$ & $3.32 E-02$ & $3.34 \mathrm{E}-02$ & $3.32 \mathrm{E}-02$ & $3.25 \mathrm{E}-02$ & $3.15 \mathrm{E}-02$ & $3.00 E-02$ & $2.82 E-02$ & $\begin{array}{r}2.60 \mathrm{E}-02 \\
\end{array}$ & $2.35 E-02$ & $2.08 \mathrm{E}-02$ & $1.85 \mathrm{E}-02$ \\
\hline KR 83 & $1.84 \mathrm{E}-03$ & $1.95 E-03$ & $2.12 \mathrm{E}-03$ & $2.27 E-03$ & $2.41 E-03$ & $2.51 \mathrm{E}-03$ & $2.58 \mathrm{E}-03$ & $2.63 \mathrm{E}-03$ & $2.64 \mathrm{E}-03$ & $2.62 \mathrm{E}-03$ & $2.57 \mathrm{E}-03$ & $2.49 \mathrm{E}-03$ & $2.38 \mathrm{E}-03$ & $2.24 \mathrm{E}-03$ & $2.08 E-03$ & $1.88 \mathrm{E}-03$ & $1.68 \mathrm{E}-03$ & $1.49 \mathrm{E}-03$ \\
\hline KR 84 & $3.54 \mathrm{E}-03$ & $3.78 \mathrm{E}-03$ & $4.12 \mathrm{E}-03$ & $4.44 E-03$ & $4.72 E-03$ & $4.94 \mathrm{E}-03$ & $5.09 E-03$ & $5.18 \mathrm{E}-03$ & $5.21 \mathrm{E}-03$ & $5.17 E-03$ & $5.07 E-03$ & $4.90 \mathrm{E}-03$ & $4.67 \mathrm{E}-03$ & $4.38 \mathrm{E}-03$ & $4.04 E-03$ & $3.64 \mathrm{E}-03$ & $3.22 \mathrm{E}-03$ & $2.85 \mathrm{E}-03$ \\
\hline KR 85 & $2.49 E-04$ & $2.65 \mathrm{E}-04$ & $2.89 E-04$ & $3.11 E-04$ & $3.30 \mathrm{E}-04$ & $3.45 E-04$ & $3.56 \mathrm{E}-04$ & $3.62 \mathrm{E}-04$ & $3.64 \mathrm{E}-04$ & $3.61 \mathrm{E}-04$ & $3.54 \mathrm{E}-04$ & $3.43 E-04$ & $3.27 E-04$ & $3.07 E-04$ & $2.83 \mathrm{E}-04$ & $2.56 \mathrm{E}-04$ & $2.27 \mathrm{E}-04$ & $2.01 \mathrm{E}-04$ \\
\hline RB 85 & $3.99 \mathrm{E}-03$ & $4.23 \mathrm{E}-03$ & $4.59 E-03$ & $4.94 E-03$ & $5.24 \mathrm{E}-03$ & $5.47 E-03$ & $5.63 \mathrm{E}-03$ & $5.73 \mathrm{E}-03$ & $5.76 \mathrm{E}-03$ & $5.72 \mathrm{E}-03$ & 5.61E-03 & $5.43 \mathrm{E}-03$ & $5.19 \mathrm{E}-03$ & $4.88 \mathrm{E}-03$ & $4.50 \mathrm{E}-03$ & $4.08 E-03$ & $3.62 E-03$ & $3.23 \mathrm{E}-03$ \\
\hline
\end{tabular}


Table A-1d. Composition (grams) in 2-inch fuel segment: ORIGEN calculation results for Pin195011, decayed to 3/11/2011.

\begin{tabular}{|c|c|c|c|c|c|c|c|c|c|c|c|c|c|c|c|c|c|c|}
\hline Position: & 1 & 3 & 5 & 7 & 9 & 11 & 13 & 15 & 17 & 19 & 21 & 23 & 25 & 27 & 29 & 31 & 33 & 35 \\
\hline KR 86 & $6.60 \mathrm{E}-03$ & $7.01 \mathrm{E}-03$ & $7.62 \mathrm{E}-03$ & $8.21 \mathrm{E}-03$ & $8.70 \mathrm{E}-03$ & 9.09E-03 & 9.37E-03 & 9.53E-03 & $9.58 \mathrm{E}-03$ & $9.51 \mathrm{E}-03$ & $9.32 \mathrm{E}-03$ & $9.02 \mathrm{E}-03$ & 8.62E-03 & $8.10 \mathrm{E}-03$ & 7.47E-03 & $6.76 \mathrm{E}-03$ & $5.99 \mathrm{E}-03$ & $5.33 \mathrm{E}-03$ \\
\hline RB 86 & $0.00 \mathrm{E}+00$ & $0.00 \mathrm{E}+00$ & $.00 E+00$ & $0.00 \mathrm{E}+00$ & $0.00 \mathrm{E}+00$ & $0.00 \mathrm{E}+00$ & $.00 E+00$ & $.00 E+00$ & $0.00 E+00$ & $0.00 \mathrm{E}+00$ & $0.00 \mathrm{E}+00$ & $0.00 E+00$ & $0.00 \mathrm{E}+00$ & $0.00 E+00$ & $0.00 \mathrm{E}+00$ & $0.00 \mathrm{E}+00$ & $0.00 \mathrm{E}+00$ & $0.00 \mathrm{E}+00$ \\
\hline SR 86 & $3.72 \mathrm{E}-05$ & $4.56 \mathrm{E}-05$ & $5.58 \mathrm{E}-05$ & $6.61 \mathrm{E}-05$ & $7.54 \mathrm{E}-05$ & $8.32 \mathrm{E}-05$ & $8.89 \mathrm{E}-05$ & $9.24 \mathrm{E}-05$ & $9.34 \mathrm{E}-05$ & $9.19 \mathrm{E}-05$ & $8.80 \mathrm{E}-05$ & $8.19 \mathrm{E}-05$ & $7.40 \mathrm{E}-05$ & $6.45 \mathrm{E}-05$ & $5.41 \mathrm{E}-05$ & $4.33 \mathrm{E}-05$ & $3.30 \mathrm{E}-05$ & $2.42 \mathrm{E}-05$ \\
\hline RB 87 & $8.40 \mathrm{E}-03$ & $8.92 \mathrm{E}-03$ & $9.70 \mathrm{E}-03$ & $1.04 \mathrm{E}-02$ & 1.11E-02 & 1.16E-02 & 1.19E-02 & $1.21 \mathrm{E}-02$ & $1.22 \mathrm{E}-02$ & $1.21 \mathrm{E}-02$ & 1.19E-02 & $1.15 \mathrm{E}-02$ & 1.10E-02 & $1.03 \mathrm{E}-02$ & $9.51 \mathrm{E}-03$ & $8.60 \mathrm{E}-03$ & 7.63E- 03 & $6.79 \mathrm{E}-03$ \\
\hline SR 87 & $1.75 \mathrm{E}-07$ & $2.15 \mathrm{E}-07$ & $2.69 \mathrm{E}-07$ & $3.28 \mathrm{E}-07$ & $3.84 \mathrm{E}-07$ & 4.33E-07 & $4.71 \mathrm{E}-07$ & 4.94E-07 & $5.01 \mathrm{E}-07$ & $4.91 \mathrm{E}-07$ & $4.65 \mathrm{E}-07$ & $4.25 \mathrm{E}-07$ & $3.75 \mathrm{E}-07$ & $3.19 \mathrm{E}-07$ & $2.60 \mathrm{E}-07$ & $2.04 \mathrm{E}-07$ & $1.55 \mathrm{E}-07$ & 1.17E-07 \\
\hline SR 88 & $1.24 \mathrm{E}-02$ & $1.31 \mathrm{E}-02$ & $1.43 \mathrm{E}-02$ & $1.54 \mathrm{E}-02$ & 1.63E-02 & $1.70 \mathrm{E}-02$ & $1.75 \mathrm{E}-02$ & $1.78 \mathrm{E}-02$ & $1.79 \mathrm{E}-02$ & $1.78 \mathrm{E}-02$ & $1.74 \mathrm{E}-02$ & $1.69 \mathrm{E}-02$ & 1.61E-02 & 1.52E-02 & $1.40 \mathrm{E}-02$ & $1.27 \mathrm{E}-02$ & 1.12E-02 & $9.99 \mathrm{E}-03$ \\
\hline SR 89 & $1.37 \mathrm{E}-42$ & $1.37 \mathrm{E}-42$ & $1.50 \mathrm{E}-42$ & 1.62E-42 & $1.75 \mathrm{E}-42$ & $1.75 E-42$ & $1.87 \mathrm{E}-42$ & $1.87 \mathrm{E}-42$ & $1.87 \mathrm{E}-42$ & $1.87 \mathrm{E}-42$ & $1.87 \mathrm{E}-42$ & $1.75 \mathrm{E}-42$ & $1.75 E-42$ & 1.62E-42 & 1.50E-42 & $1.37 E-42$ & $1.25 \mathrm{E}-42$ & $1.12 \mathrm{E}-42$ \\
\hline Y 89 & $1.56 \mathrm{E}-02$ & 1.66E-02 & $1.80 \mathrm{E}-02$ & $1.94 \mathrm{E}-02$ & $2.06 \mathrm{E}-02$ & 2.15E-02 & $2.21 \mathrm{E}-02$ & $2.25 \mathrm{E}-02$ & $2.26 \mathrm{E}-02$ & 2.24E-02 & 2.20E-02 & $2.13 \mathrm{E}-02$ & $2.04 \mathrm{E}-02$ & $1.91 \mathrm{E}-02$ & $1.77 \mathrm{E}-02$ & $1.60 \mathrm{E}-02$ & 1.42E-02 & $1.26 \mathrm{E}-02$ \\
\hline SR 90 & $1.17 \mathrm{E}-02$ & $1.24 \mathrm{E}-02$ & $1.35 \mathrm{E}-02$ & $1.45 \mathrm{E}-02$ & $1.54 \mathrm{E}-02$ & $1.61 \mathrm{E}-02$ & $1.65 \mathrm{E}-02$ & $1.68 \mathrm{E}-02$ & $1.69 \mathrm{E}-02$ & $1.68 \mathrm{E}-02$ & $1.65 \mathrm{E}-02$ & $1.59 \mathrm{E}-02$ & $1.52 \mathrm{E}-02$ & $1.43 \mathrm{E}-02$ & $1.32 \mathrm{E}-02$ & 1.19E-02 & $1.06 \mathrm{E}-02$ & $9.44 \mathrm{E}-03$ \\
\hline Y90 & $2.93 \mathrm{E}-06$ & $3.11 \mathrm{E}-06$ & $3.38 \mathrm{E}-06$ & $3.63 \mathrm{E}-06$ & $3.85 \mathrm{E}-06$ & $4.02 E-06$ & $4.15 \mathrm{E}-06$ & 4.22E-06 & $4.24 \mathrm{E}-06$ & 4.21E-06 & 4.13E-06 & $3.99 \mathrm{E}-06$ & $3.81 \mathrm{E}-06$ & $3.59 \mathrm{E}-06$ & $3.31 \mathrm{E}-06$ & $3.00 \mathrm{E}-06$ & $2.66 \mathrm{E}-06$ & $2.37 \mathrm{E}-06$ \\
\hline ZR 90 & 7.37E-03 & $7.82 \mathrm{E}-03$ & $8.50 \mathrm{E}-03$ & $9.15 \mathrm{E}-03$ & $9.70 \mathrm{E}-03$ & $1.01 \mathrm{E}-02$ & $1.05 \mathrm{E}-02$ & $1.06 \mathrm{E}-02$ & $1.07 \mathrm{E}-02$ & $1.06 \mathrm{E}-02$ & $1.04 \mathrm{E}-02$ & $1.01 \mathrm{E}-02$ & $9.60 \mathrm{E}-03$ & $9.02 E-03$ & $8.32 E-03$ & $7.53 \mathrm{E}-03$ & $6.68 \mathrm{E}-03$ & $5.95 \mathrm{E}-03$ \\
\hline Y91 & 4.34E-37 & $4.62 \mathrm{E}-37$ & 4.99E- 37 & $5.33 \mathrm{E}-37$ & $5.61 \mathrm{E}-37$ & $5.82 E-37$ & $5.98 \mathrm{E}-37$ & $6.06 \mathrm{E}-37$ & $6.09 \mathrm{E}-37$ & $6.06 \mathrm{E}-37$ & $5.97 E-37$ & $5.82 \mathrm{E}-37$ & $5.60 \mathrm{E}-37$ & $5.31 E-37$ & $4.95 E-37$ & $4.53 \mathrm{E}-37$ & 4.06E-37 & $3.63 \mathrm{E}-37$ \\
\hline ZR 91 & $1.98 \mathrm{E}-02$ & $2.10 \mathrm{E}-02$ & $2.28 \mathrm{E}-02$ & $2.46 \mathrm{E}-02$ & $2.60 \mathrm{E}-02$ & $2.72 \mathrm{E}-02$ & $2.80 \mathrm{E}-02$ & $2.85 \mathrm{E}-02$ & $2.86 \mathrm{E}-02$ & $2.84 \mathrm{E}-02$ & $2.79 \mathrm{E}-02$ & $2.70 \mathrm{E}-02$ & $2.58 \mathrm{E}-02$ & $2.42 \mathrm{E}-02$ & $2.24 \mathrm{E}-02$ & $2.02 \mathrm{E}-02$ & $1.80 \mathrm{E}-02$ & $1.60 \mathrm{E}-02$ \\
\hline ZR 92 & $2.09 \mathrm{E}-02$ & $2.22 \mathrm{E}-02$ & $2.41 \mathrm{E}-02$ & $2.60 \mathrm{E}-02$ & $2.76 \mathrm{E}-02$ & $2.88 \mathrm{E}-02$ & $2.97 \mathrm{E}-02$ & $3.02 E-02$ & $3.04 \mathrm{E}-02$ & $3.02 \mathrm{E}-02$ & $2.96 \mathrm{E}-02$ & 2.86E-02 & $2.73 \mathrm{E}-02$ & $56 \mathrm{E}-02$ & $2.37 \mathrm{E}-02$ & $14 \mathrm{E}-02$ & $1.89 \mathrm{E}-02$ & $1.68 \mathrm{E}-02$ \\
\hline ZR 93 & $2.29 \mathrm{E}-02$ & $2.44 \mathrm{E}-02$ & $2.65 \mathrm{E}-02$ & $2.86 \mathrm{E}-02$ & $3.03 \mathrm{E}-02$ & $3.17 \mathrm{E}-02$ & $3.27 \mathrm{E}-02$ & $3.32 \mathrm{E}-02$ & $3.34 \mathrm{E}-02$ & 3.32E-02 & $3.25 \mathrm{E}-02$ & $3.15 \mathrm{E}-02$ & $3.00 \mathrm{E}-02$ & $2.82 \mathrm{E}-02$ & $2.60 \mathrm{E}-02$ & $2.35 \mathrm{E}-02$ & $2.08 \mathrm{E}-02$ & $1.85 \mathrm{E}-02$ \\
\hline NB 93 & $8.49 \mathrm{E}-08$ & $9.03 \mathrm{E}-08$ & $9.82 \mathrm{E}-08$ & $1.06 \mathrm{E}-07$ & 1.12E- 07 & $1.17 \mathrm{E}-07$ & $1.21 \mathrm{E}-07$ & 1.23E-07 & $1.24 \mathrm{E}-07$ & 1.23E-07 & 1.20E-07 & 1.17E-07 & 1.11E-07 & $1.04 \mathrm{E}-07$ & $9.62 \mathrm{E}-08$ & $8.70 \mathrm{E}-08$ & $7.70 \mathrm{E}-08$ & $6.84 \mathrm{E}-08$ \\
\hline NB 93M & $1.24 \mathrm{E}-07$ & $1.32 \mathrm{E}-07$ & $1.44 \mathrm{E}-07$ & $1.55 \mathrm{E}-07$ & $1.64 \mathrm{E}-07$ & $1.72 \mathrm{E}-07$ & 1.77E- 07 & $1.80 \mathrm{E}-07$ & $1.81 \mathrm{E}-07$ & $1.80 \mathrm{E}-07$ & 1.76E-07 & $1.70 \mathrm{E}-07$ & $1.63 \mathrm{E}-07$ & 1.53E-07 & $1.41 \mathrm{E}-07$ & $1.27 \mathrm{E}-07$ & 1.13E- 07 & $1.00 \mathrm{E}-07$ \\
\hline ZR 94 & $2.22 \mathrm{E}-02$ & $2.36 \mathrm{E}-02$ & $2.57 \mathrm{E}-02$ & $2.78 \mathrm{E}-02$ & $2.95 \mathrm{E}-02$ & $3.08 \mathrm{E}-02$ & $3.18 \mathrm{E}-02$ & $3.23 \mathrm{E}-02$ & $3.25 \mathrm{E}-02$ & $3.23 \mathrm{E}-02$ & 3.16E-02 & $3.06 \mathrm{E}-02$ & $2.92 \mathrm{E}-02$ & $2.74 \mathrm{E}-02$ & 2.52E-02 & $2.28 \mathrm{E}-02$ & $2.02 \mathrm{E}-02$ & $1.79 \mathrm{E}-02$ \\
\hline ZR 95 & 4.34E-34 & 4.63E-34 & $5.01 \mathrm{E}-34$ & $5.37 \mathrm{E}-34$ & $5.66 \mathrm{E}-34$ & $5.89 \mathrm{E}-34$ & $6.05 \mathrm{E}-34$ & $6.14 \mathrm{E}-34$ & $6.18 \mathrm{E}-34$ & $6.14 \mathrm{E}-34$ & $6.04 \mathrm{E}-34$ & $5.88 \mathrm{E}-34$ & $5.65 E-34$ & $5.35 \mathrm{E}-34$ & $4.97 \mathrm{E}-34$ & 4.54E-34 & $4.05 \mathrm{E}-34$ & $3.61 \mathrm{E}-34$ \\
\hline NB 95 & $2.44 \mathrm{E}-34$ & $2.61 \mathrm{E}-34$ & $2.82 \mathrm{E}-34$ & $3.02 E-34$ & $3.19 \mathrm{E}-34$ & $3.32 \mathrm{E}-34$ & $3.41 \mathrm{E}-34$ & $3.46 \mathrm{E}-34$ & $3.48 \mathrm{E}-34$ & $3.46 \mathrm{E}-34$ & $3.40 \mathrm{E}-34$ & $3.31 \mathrm{E}-34$ & $3.18 E-34$ & $3.01 \mathrm{E}-34$ & $2.80 \mathrm{E}-34$ & $2.55 \mathrm{E}-34$ & $2.28 \mathrm{E}-34$ & $2.03 \mathrm{E}-34$ \\
\hline NB 95M & $1.72 \mathrm{E}-37$ & $1.83 \mathrm{E}-37$ & $1.98 \mathrm{E}-37$ & $2.12 \mathrm{E}-37$ & $2.24 \mathrm{E}-37$ & $2.33 \mathrm{E}-37$ & 2.39E-37 & $2.43 \mathrm{E}-37$ & 2.44E-37 & $2.43 E-37$ & $2.39 \mathrm{E}-37$ & $2.32 \mathrm{E}-37$ & $2.23 E-37$ & 2.11E-37 & $1.97 \mathrm{E}-37$ & $1.79 E-37$ & 1.60E-37 & $1.43 \mathrm{E}-37$ \\
\hline MO 95 & $2.35 \mathrm{E}-02$ & $2.50 \mathrm{E}-02$ & $2.72 \mathrm{E}-02$ & $2.92 \mathrm{E}-02$ & $3.10 \mathrm{E}-02$ & $3.24 \mathrm{E}-02$ & 3.34E-02 & 3.39E-02 & $3.41 \mathrm{E}-02$ & $3.38 \mathrm{E}-02$ & $3.32 \mathrm{E}-02$ & $3.21 \mathrm{E}-02$ & $3.07 E-02$ & $2.88 \mathrm{E}-02$ & $2.66 \mathrm{E}-02$ & $2.41 \mathrm{E}-02$ & 2.14E- 02 & $1.90 \mathrm{E}-02$ \\
\hline ZR 96 & $2.34 \mathrm{E}-02$ & $2.50 \mathrm{E}-02$ & $2.72 \mathrm{E}-02$ & $2.93 \mathrm{E}-02$ & $3.11 \mathrm{E}-02$ & $3.26 \mathrm{E}-02$ & 3.36E-02 & $3.41 \mathrm{E}-02$ & $3.43 \mathrm{E}-02$ & $3.41 \mathrm{E}-02$ & $3.34 \mathrm{E}-02$ & $3.23 \mathrm{E}-02$ & $3.08 \mathrm{E}-02$ & $2.89 \mathrm{E}-02$ & $2.66 \mathrm{E}-02$ & $2.41 \mathrm{E}-02$ & 2.13E-02 & $1.89 \mathrm{E}-02$ \\
\hline MO 96 & $2.90 \mathrm{E}-04$ & 3.57E-04 & $4.38 \mathrm{E}-04$ & $5.18 \mathrm{E}-04$ & $5.92 \mathrm{E}-04$ & $6.54 \mathrm{E}-04$ & $6.99 \mathrm{E}-04$ & $7.27 \mathrm{E}-04$ & $7.35 \mathrm{E}-04$ & $7.23 \mathrm{E}-04$ & $6.92 \mathrm{E}-04$ & $6.44 \mathrm{E}-04$ & $5.81 \mathrm{E}-04$ & $5.06 \mathrm{E}-04$ & 4.24E- -04 & $3.39 \mathrm{E}-04$ & $2.58 \mathrm{E}-04$ & $1.88 \mathrm{E}-04$ \\
\hline
\end{tabular}

Position=Segment location (midpoint of 2 -in. segment) from bottom of fuel (BOF); 2 in. of fuel $\sim 14.2 \mathrm{~g}$. 
Table A-1e. Composition (grams) in 2-inch fuel segment: ORIGEN calculation results for Pin195011, decayed to 3/11/2011.

\begin{tabular}{|c|c|c|c|c|c|c|c|c|c|c|c|c|c|c|c|c|c|c|}
\hline Position: & 1 & 3 & 5 & 7 & 9 & 11 & 13 & 15 & 17 & 19 & 21 & 23 & 25 & 27 & 29 & 31 & 33 & 35 \\
\hline MO 97 & $2.26 \mathrm{E}-02$ & 2.41E-02 & 2.62E-02 & $2.82 \mathrm{E}-02$ & $2.99 \mathrm{E}-02$ & 3.13E- 02 & $3.22 \mathrm{E}-02$ & $3.28 \mathrm{E}-02$ & $3.29 \mathrm{E}-02$ & $3.27 \mathrm{E}-02$ & $3.21 \mathrm{E}-02$ & $3.10 \mathrm{E}-02$ & $2.96 \mathrm{E}-02$ & $2.78 \mathrm{E}-02$ & $2.57 \mathrm{E}-02$ & 2.32E- 02 & $2.06 \mathrm{E}-02$ & $1.83 \mathrm{E}-02$ \\
\hline MO 98 & $2.34 \mathrm{E}-02$ & $2.50 \mathrm{E}-02$ & $2.72 \mathrm{E}-02$ & $2.94 \mathrm{E}-02$ & 3.13E-02 & 3.28E-02 & $3.38 \mathrm{E}-02$ & $3.44 \mathrm{E}-02$ & $3.46 \mathrm{E}-02$ & $3.43 \mathrm{E}-02$ & $3.36 \mathrm{E}-02$ & $3.25 \mathrm{E}-02$ & $3.10 \mathrm{E}-02$ & $2.90 \mathrm{E}-02$ & 2.67E-02 & $2.41 \mathrm{E}-02$ & 2.12E-02 & $1.88 \mathrm{E}-02$ \\
\hline TC 98 & 4.83E-07 & $5.95 \mathrm{E}-07$ & $7.32 \mathrm{E}-07$ & $8.68 \mathrm{E}-07$ & $9.92 \mathrm{E}-07$ & 1.10E-06 & 1.17E-06 & $1.22 \mathrm{E}-06$ & 1.23E- 06 & 1.21E-06 & 1.16E-06 & $1.08 \mathrm{E}-06$ & $9.73 \mathrm{E}-07$ & 8.47E-07 & $7.09 \mathrm{E}-07$ & $5.66 \mathrm{E}-07$ & 4.29E-07 & $3.12 \mathrm{E}-07$ \\
\hline TC 99 & 2.24E- 02 & $2.38 \mathrm{E}-02$ & $2.59 \mathrm{E}-02$ & $2.79 \mathrm{E}-02$ & $2.96 \mathrm{E}-02$ & 3.09E-02 & $3.18 \mathrm{E}-02$ & $3.24 \mathrm{E}-02$ & $3.25 \mathrm{E}-02$ & $3.23 \mathrm{E}-02$ & 3.17E-02 & $3.07 \mathrm{E}-02$ & $2.93 \mathrm{E}-02$ & $2.75 \mathrm{E}-02$ & $2.54 \mathrm{E}-02$ & $2.30 \mathrm{E}-02$ & 2.04E-02 & $1.81 \mathrm{E}-02$ \\
\hline RU 99 & 1.46E-06 & $1.56 \mathrm{E}-06$ & 1.69E-06 & 1.82E-06 & $1.93 \mathrm{E}-06$ & $2.02 \mathrm{E}-06$ & $2.08 \mathrm{E}-06$ & $2.12 \mathrm{E}-06$ & 2.13E- 06 & 2.11E-06 & $2.07 \mathrm{E}-06$ & $2.00 \mathrm{E}-06$ & $1.91 \mathrm{E}-06$ & 1.80E-06 & 1.66E-06 & $1.50 \mathrm{E}-06$ & 1.33E-06 & 1.18E-06 \\
\hline MO100 & $2.50 \mathrm{E}-02$ & $2.67 \mathrm{E}-02$ & $2.91 \mathrm{E}-02$ & $3.14 \mathrm{E}-02$ & $3.33 \mathrm{E}-02$ & $3.48 \mathrm{E}-02$ & $3.59 \mathrm{E}-02$ & $3.66 \mathrm{E}-02$ & $3.67 \mathrm{E}-02$ & $3.65 \mathrm{E}-02$ & $3.57 \mathrm{E}-02$ & $3.46 \mathrm{E}-02$ & $3.30 \mathrm{E}-02$ & $3.09 \mathrm{E}-02$ & $2.85 \mathrm{E}-02$ & $2.57 \mathrm{E}-02$ & $2.27 \mathrm{E}-02$ & $2.01 \mathrm{E}-02$ \\
\hline RU100 & $5.32 \mathrm{E}-04$ & $6.55 \mathrm{E}-04$ & $8.05 \mathrm{E}-04$ & $9.54 \mathrm{E}-04$ & $1.09 \mathrm{E}-03$ & 1.20E-03 & 1.29E-03 & $1.34 \mathrm{E}-03$ & 1.35E-03 & 1.33E-03 & $1.27 \mathrm{E}-03$ & $1.19 \mathrm{E}-03$ & $1.07 \mathrm{E}-03$ & $9.31 \mathrm{E}-04$ & $7.80 \mathrm{E}-04$ & 6.24E- 04 & $4.73 \mathrm{E}-04$ & 3.44E-04 \\
\hline RU101 & $2.17 \mathrm{E}-02$ & $2.31 \mathrm{E}-02$ & $2.52 \mathrm{E}-02$ & $2.71 \mathrm{E}-02$ & $2.88 \mathrm{E}-02$ & $3.01 \mathrm{E}-02$ & 3.10E-02 & $3.15 \mathrm{E}-02$ & $3.16 \mathrm{E}-02$ & $3.14 \mathrm{E}-02$ & $3.08 \mathrm{E}-02$ & $2.98 \mathrm{E}-02$ & $2.85 \mathrm{E}-02$ & 2.67E-02 & $2.47 \mathrm{E}-02$ & 2.23E- 02 & $1.98 \mathrm{E}-02$ & $1.75 \mathrm{E}-02$ \\
\hline RU102 & $1.98 \mathrm{E}-02$ & 2.13E- 02 & 2.33E-02 & $2.53 \mathrm{E}-02$ & $2.70 \mathrm{E}-02$ & $2.83 \mathrm{E}-02$ & $2.92 \mathrm{E}-02$ & $2.98 \mathrm{E}-02$ & 2.99E- 02 & $2.97 \mathrm{E}-02$ & $2.91 \mathrm{E}-02$ & $2.81 \mathrm{E}-02$ & 2.67E-02 & $2.49 \mathrm{E}-02$ & 2.29E-02 & $2.05 \mathrm{E}-02$ & $1.80 \mathrm{E}-02$ & $1.58 \mathrm{E}-02$ \\
\hline RH102 & $9.34 \mathrm{E}-10$ & 1.16E-09 & 1.43E-09 & $1.70 \mathrm{E}-09$ & $1.94 \mathrm{E}-09$ & 2.15E-09 & $2.30 \mathrm{E}-09$ & $2.39 \mathrm{E}-09$ & 2.42E-09 & $2.38 \mathrm{E}-09$ & $2.28 \mathrm{E}-09$ & 2.12E-09 & $1.91 \mathrm{E}-09$ & 1.66E-09 & 1.39E-09 & 1.11E-09 & $8.36 \mathrm{E}-10$ & $6.04 \mathrm{E}-10$ \\
\hline RU103 & $0.00 E+00$ & $0.00 \mathrm{E}+00$ & $0.00 E+00$ & $0.00 \mathrm{E}+00$ & $0.00 E+00$ & $0.00 \mathrm{E}+00$ & $0.00 \mathrm{E}+00$ & $0.00 E+00$ & $0.00 \mathrm{E}+00$ & $0.00 \mathrm{E}+00$ & $0.00 \mathrm{E}+00$ & $0.00 \mathrm{E}+00$ & $0.00 E+00$ & $0.00 E+00$ & $0.00 \mathrm{E}+00$ & $0.00 E+00$ & $0.00 \mathrm{E}+00$ & $0.00 \mathrm{E}+00$ \\
\hline RH103 & $1.43 \mathrm{E}-02$ & $1.54 \mathrm{E}-02$ & 1.68E-02 & $1.81 \mathrm{E}-02$ & $1.93 \mathrm{E}-02$ & 2.02E-02 & $2.08 \mathrm{E}-02$ & 2.12E-02 & 2.13E-02 & 2.11E-02 & $2.07 \mathrm{E}-02$ & $2.00 \mathrm{E}-02$ & $1.91 \mathrm{E}-02$ & $1.79 \mathrm{E}-02$ & 1.64E-02 & $1.48 \mathrm{E}-02$ & $1.31 \mathrm{E}-02$ & 1.15E-02 \\
\hline RH103M & $0.00 \mathrm{E}+00$ & $0.00 \mathrm{E}+00$ & $0.00 \mathrm{E}+00$ & $0.00 \mathrm{E}+00$ & $0.00 E+00$ & $0.00 \mathrm{E}+00$ & $0.00 \mathrm{E}+00$ & $0.00 \mathrm{E}+00$ & $0.00 \mathrm{E}+00$ & $0.00 \mathrm{E}+00$ & $0.00 \mathrm{E}+00$ & $0.00 \mathrm{E}+00$ & $0.00 E+00$ & $0.00 \mathrm{E}+00$ & $0.00 \mathrm{E}+00$ & $0.00 E+00$ & $0.00 \mathrm{E}+00$ & $0.00 E+00$ \\
\hline RU104 & $1.08 \mathrm{E}-02$ & 1.17E-02 & 1.28E-02 & 1.39E-02 & 1.49E-02 & $1.56 \mathrm{E}-02$ & $1.62 \mathrm{E}-02$ & $1.65 \mathrm{E}-02$ & $1.65 \mathrm{E}-02$ & $1.64 \mathrm{E}-02$ & $1.61 \mathrm{E}-02$ & $1.55 \mathrm{E}-02$ & $1.47 \mathrm{E}-02$ & $1.37 \mathrm{E}-02$ & 1.26E-02 & 1.13E-02 & $9.87 \mathrm{E}-03$ & $8.58 \mathrm{E}-03$ \\
\hline PD104 & $5.13 \mathrm{E}-04$ & 6.36E-04 & $7.84 \mathrm{E}-04$ & $9.31 \mathrm{E}-04$ & $1.06 \mathrm{E}-03$ & 1.18E-03 & 1.26E-03 & 1.31E-03 & $1.32 E-03$ & $1.30 \mathrm{E}-03$ & 1.25E-03 & 1.16E-03 & $1.04 \mathrm{E}-03$ & $9.09 \mathrm{E}-04$ & $7.60 \mathrm{E}-04$ & 6.07E-04 & 4.59E- 04 & 3.32E-04 \\
\hline PD105 & $6.07 \mathrm{E}-03$ & $6.62 \mathrm{E}-03$ & $7.30 \mathrm{E}-03$ & $7.93 \mathrm{E}-03$ & $8.46 \mathrm{E}-03$ & $8.89 \mathrm{E}-03$ & $9.18 \mathrm{E}-03$ & $9.36 \mathrm{E}-03$ & $9.41 \mathrm{E}-03$ & $9.34 \mathrm{E}-03$ & $9.13 \mathrm{E}-03$ & $8.81 \mathrm{E}-03$ & $8.37 \mathrm{E}-03$ & $7.82 \mathrm{E}-03$ & $7.16 \mathrm{E}-03$ & $6.41 \mathrm{E}-03$ & $5.60 \mathrm{E}-03$ & $4.84 \mathrm{E}-03$ \\
\hline RU106 & 4.25E-09 & $4.70 \mathrm{E}-09$ & $5.25 \mathrm{E}-09$ & $5.76 \mathrm{E}-09$ & $6.21 \mathrm{E}-09$ & $6.56 \mathrm{E}-09$ & $6.81 \mathrm{E}-09$ & $6.96 \mathrm{E}-09$ & $7.01 \mathrm{E}-09$ & $6.94 \mathrm{E}-09$ & $6.78 \mathrm{E}-09$ & $6.51 \mathrm{E}-09$ & $6.15 \mathrm{E}-09$ & $5.69 \mathrm{E}-09$ & $5.16 \mathrm{E}-09$ & 4.57E-09 & $3.94 \mathrm{E}-09$ & $3.34 \mathrm{E}-09$ \\
\hline PD106 & $3.93 \mathrm{E}-03$ & 4.39E-03 & 4.93E-03 & $5.45 \mathrm{E}-03$ & $5.90 \mathrm{E}-03$ & $6.26 \mathrm{E}-03$ & $6.51 \mathrm{E}-03$ & $6.67 \mathrm{E}-03$ & $6.71 \mathrm{E}-03$ & $6.65 \mathrm{E}-03$ & $6.47 \mathrm{E}-03$ & $6.19 \mathrm{E}-03$ & $5.82 \mathrm{E}-03$ & $5.36 \mathrm{E}-03$ & 4.83E-03 & 4.24E-03 & $3.62 \mathrm{E}-03$ & $3.05 \mathrm{E}-03$ \\
\hline PD107 & $2.39 \mathrm{E}-03$ & 2.63E- 03 & $2.92 \mathrm{E}-03$ & $3.20 \mathrm{E}-03$ & $3.44 \mathrm{E}-03$ & $3.63 \mathrm{E}-03$ & $3.76 E-03$ & $3.84 \mathrm{E}-03$ & $3.86 \mathrm{E}-03$ & 3.83E-03 & $3.74 \mathrm{E}-03$ & $3.59 \mathrm{E}-03$ & $3.40 \mathrm{E}-03$ & $3.15 \mathrm{E}-03$ & $2.86 \mathrm{E}-03$ & 2.54E- -03 & $2.20 \mathrm{E}-03$ & 1.88E-03 \\
\hline AG107 & $5.11 \mathrm{E}-09$ & $5.61 \mathrm{E}-09$ & $6.24 \mathrm{E}-09$ & $6.82 \mathrm{E}-09$ & $7.33 \mathrm{E}-09$ & 7.74E- -09 & $8.02 E-09$ & $8.19 \mathrm{E}-09$ & $8.24 \mathrm{E}-09$ & $8.17 \mathrm{E}-09$ & $7.97 \mathrm{E}-09$ & $7.66 \mathrm{E}-09$ & $7.24 \mathrm{E}-09$ & $6.72 \mathrm{E}-09$ & $6.11 \mathrm{E}-09$ & $5.42 \mathrm{E}-09$ & 4.69E-09 & $4.01 \mathrm{E}-09$ \\
\hline PD108 & 1.62E-03 & $1.79 \mathrm{E}-03$ & $2.01 \mathrm{E}-03$ & $2.22 \mathrm{E}-03$ & $2.40 \mathrm{E}-03$ & $2.55 \mathrm{E}-03$ & $2.65 E-03$ & $2.71 \mathrm{E}-03$ & $2.73 \mathrm{E}-03$ & $2.71 \mathrm{E}-03$ & $2.63 \mathrm{E}-03$ & $2.52 \mathrm{E}-03$ & $2.37 \mathrm{E}-03$ & $2.18 \mathrm{E}-03$ & 1.97E-03 & $1.73 \mathrm{E}-03$ & 1.48E-03 & 1.25E-03 \\
\hline
\end{tabular}




\begin{tabular}{|c|c|c|c|c|c|c|c|c|c|c|c|c|c|c|c|c|c|c|}
\hline CD108 & & & & & & & & & & & & & & & & & & \\
\hline & $1.83 E-08$ & $2.33 E-08$ & $2.92 E-08$ & $3.51 \mathrm{E}-08$ & $4.05 E-08$ & $4.51 E-08$ & $4.85 \mathrm{E}-08$ & $5.06 \mathrm{E}-08$ & $5.12 \mathrm{E}-08$ & $5.03 E-08$ & $4.80 E-08$ & $4.43 E-08$ & $3.97 E-08$ & $3.42 E-08$ & $2.82 E-08$ & $2.22 E-08$ & $1.65 \mathrm{E}-08$ & 1.16E -08 \\
\hline AG 109 & 1.11E -03 & $1.23 E-03$ & $1.37 \mathrm{E}-03$ & $1.50 \mathrm{E}-03$ & $1.62 \mathrm{E}-03$ & $1.71 \mathrm{E}-03$ & $1.78 \mathrm{E}-03$ & $1.82 E-03$ & $1.83 \mathrm{E}-03$ & $1.81 \mathrm{E}-03$ & $1.77 \mathrm{E}-03$ & $1.70 \mathrm{E}-03$ & $1.60 \mathrm{E}-03$ & $1.48 \mathrm{E}-03$ & $1.34 \mathrm{E}-03$ & $1.18 \mathrm{E}-03$ & $1.02 E-03$ & $8.66 \mathrm{E}-04$ \\
\hline PD110 & $7.83 E-04$ & $8.65 E-04$ & $9.60 \mathrm{E}-04$ & $1.05 E-03$ & $1.12 \mathrm{E}-03$ & $1.18 \mathrm{E}-03$ & $1.22 \mathrm{E}-03$ & $1.25 \mathrm{E}-03$ & $1.26 \mathrm{E}-03$ & $1.25 \mathrm{E}-03$ & $1.22 E-03$ & 1.1.17E-03 & $1.11 \mathrm{E}-03$ & $1.03 \mathrm{E}-03$ & $9.42 E-04$ & $8.39 \mathrm{E}-04$ & $7.28 E-04$ & $6.20 \mathrm{E}-04$ \\
\hline
\end{tabular}

Position=Segment location (midpoint of 2-in. segment) from bottom of fuel (BOF); 2 in. of fuel $\sim 14.2 \mathrm{~g}$. 
Table A-1f. Composition (grams) in 2-inch fuel segment: ORIGEN calculation results for Pin195011, decayed to 3/11/2011.

\begin{tabular}{|c|c|c|c|c|c|c|c|c|c|c|c|c|c|c|c|c|c|c|}
\hline Position: & 1 & 3 & 5 & 7 & 9 & 11 & 13 & 15 & 17 & 19 & 21 & 23 & 25 & 27 & 29 & 31 & 33 & 35 \\
\hline AG110M & $1.59 \mathrm{E}-14$ & $2.02 E-14$ & $2.54 \mathrm{E}-14$ & $3.06 \mathrm{E}-14$ & $3.54 \mathrm{E}-14$ & $3.94 \mathrm{E}-14$ & $4.24 \mathrm{E}-14$ & 4.42E-14 & 4.48E-14 & $4.40 \mathrm{E}-14$ & $4.20 \mathrm{E}-14$ & $3.88 \mathrm{E}-14$ & $3.48 \mathrm{E}-14$ & $2.99 \mathrm{E}-14$ & $2.47 \mathrm{E}-14$ & $1.94 \mathrm{E}-14$ & $1.44 \mathrm{E}-14$ & $1.01 \mathrm{E}-14$ \\
\hline CD110 & 3.25E-05 & 4.14E-05 & $5.19 \mathrm{E}-05$ & $6.24 \mathrm{E}-05$ & $7.20 \mathrm{E}-05$ & $8.02 \mathrm{E}-05$ & $8.62 \mathrm{E}-05$ & $8.99 \mathrm{E}-05$ & $9.10 \mathrm{E}-05$ & $8.94 \mathrm{E}-05$ & $8.53 \mathrm{E}-05$ & $7.88 \mathrm{E}-05$ & $7.06 \mathrm{E}-05$ & $6.08 \mathrm{E}-05$ & $5.02 \mathrm{E}-05$ & $3.95 \mathrm{E}-05$ & $2.93 \mathrm{E}-05$ & $2.06 \mathrm{E}-05$ \\
\hline AG111 & $0.00 \mathrm{E}+00$ & $0.00 \mathrm{E}+00$ & $0.00 E+00$ & $0.00 \mathrm{E}+00$ & $0.00 \mathrm{E}+00$ & $0.00 \mathrm{E}+00$ & $0.00 \mathrm{E}+00$ & $0.00 \mathrm{E}+00$ & $0.00 \mathrm{E}+00$ & $0.00 \mathrm{E}+00$ & $0.00 \mathrm{E}+00$ & $0.00 \mathrm{E}+00$ & $0.00 \mathrm{E}+00$ & $0.00 \mathrm{E}+00$ & $0.00 \mathrm{E}+00$ & $0.00 \mathrm{E}+00$ & $0.00 \mathrm{E}+00$ & $0.00 \mathrm{E}+00$ \\
\hline CD111 & $6.29 \mathrm{E}-04$ & $6.96 \mathrm{E}-04$ & $7.72 \mathrm{E}-04$ & $8.39 \mathrm{E}-04$ & $8.97 \mathrm{E}-04$ & 9.42E-04 & $9.73 \mathrm{E}-04$ & $9.92 \mathrm{E}-04$ & $9.97 \mathrm{E}-04$ & $9.89 \mathrm{E}-04$ & $9.68 \mathrm{E}-04$ & $9.34 \mathrm{E}-04$ & $8.88 \mathrm{E}-04$ & $8.29 \mathrm{E}-04$ & $7.58 \mathrm{E}-04$ & $6.79 \mathrm{E}-04$ & $5.90 \mathrm{E}-04$ & $5.03 E-04$ \\
\hline CD112 & $5.58 \mathrm{E}-04$ & $6.21 \mathrm{E}-04$ & $6.89 \mathrm{E}-04$ & $7.50 \mathrm{E}-04$ & $8.01 \mathrm{E}-04$ & $8.41 \mathrm{E}-04$ & $8.69 \mathrm{E}-04$ & $8.85 \mathrm{E}-04$ & $8.90 \mathrm{E}-04$ & $8.83 \mathrm{E}-04$ & $8.64 \mathrm{E}-04$ & $8.34 \mathrm{E}-04$ & $7.93 \mathrm{E}-04$ & $7.41 \mathrm{E}-04$ & $6.78 \mathrm{E}-04$ & $6.07 E-04$ & $5.27 \mathrm{E}-04$ & $4.48 \mathrm{E}-04$ \\
\hline CD113 & $5.27 \mathrm{E}-04$ & $5.83 \mathrm{E}-04$ & $6.44 \mathrm{E}-04$ & $6.98 \mathrm{E}-04$ & $7.44 \mathrm{E}-04$ & $7.79 \mathrm{E}-04$ & $8.04 \mathrm{E}-04$ & $8.18 \mathrm{E}-04$ & $8.22 \mathrm{E}-04$ & $8.16 \mathrm{E}-04$ & $7.99 \mathrm{E}-04$ & $7.73 \mathrm{E}-04$ & $7.37 \mathrm{E}-04$ & $6.90 \mathrm{E}-04$ & $6.34 \mathrm{E}-04$ & $5.70 \mathrm{E}-04$ & $4.98 \mathrm{E}-04$ & 4.25E-04 \\
\hline CD113M & $3.61 \mathrm{E}-06$ & $4.04 \mathrm{E}-06$ & $4.51 \mathrm{E}-06$ & $4.94 \mathrm{E}-06$ & $5.30 \mathrm{E}-06$ & $5.58 \mathrm{E}-06$ & $5.79 \mathrm{E}-06$ & $5.90 \mathrm{E}-06$ & $5.94 \mathrm{E}-06$ & $5.89 \mathrm{E}-06$ & $5.75 \mathrm{E}-06$ & $5.54 \mathrm{E}-06$ & $5.25 \mathrm{E}-06$ & 4.88E-06 & $4.44 \mathrm{E}-06$ & $3.95 \mathrm{E}-06$ & $3.41 \mathrm{E}-06$ & $2.88 \mathrm{E}-06$ \\
\hline IN113 & 5.74E-06 & $6.41 \mathrm{E}-06$ & 7.15E-06 & 7.82E-06 & $8.39 \mathrm{E}-06$ & 8.84E-06 & $9.16 \mathrm{E}-06$ & 9.34E-06 & $9.40 \mathrm{E}-06$ & $9.32 \mathrm{E}-06$ & $9.10 \mathrm{E}-06$ & $8.76 \mathrm{E}-06$ & $8.30 \mathrm{E}-06$ & $7.72 \mathrm{E}-06$ & 7.03E- 06 & $6.26 \mathrm{E}-06$ & $5.41 \mathrm{E}-06$ & 4.57E-06 \\
\hline CD114 & 5.03E-04 & $5.54 \mathrm{E}-04$ & $6.11 \mathrm{E}-04$ & $6.62 \mathrm{E}-04$ & $7.05 \mathrm{E}-04$ & 7.39E-04 & $7.62 \mathrm{E}-04$ & $7.76 \mathrm{E}-04$ & 7.80E-04 & $7.74 \mathrm{E}-04$ & $7.58 \mathrm{E}-04$ & 7.33E-04 & $6.99 \mathrm{E}-04$ & $6.54 \mathrm{E}-04$ & $6.01 \mathrm{E}-04$ & $5.40 \mathrm{E}-04$ & $4.72 \mathrm{E}-04$ & $4.05 \mathrm{E}-04$ \\
\hline SN114 & 1.49E-08 & $1.92 \mathrm{E}-08$ & $2.39 \mathrm{E}-08$ & $2.86 \mathrm{E}-08$ & $3.29 \mathrm{E}-08$ & $3.65 \mathrm{E}-08$ & $3.91 \mathrm{E}-08$ & 4.07E-08 & 4.11E-08 & $4.05 \mathrm{E}-08$ & $3.86 \mathrm{E}-08$ & 3.59E-08 & $3.22 \mathrm{E}-08$ & $2.80 \mathrm{E}-08$ & $2.32 \mathrm{E}-08$ & $1.84 \mathrm{E}-08$ & $1.37 \mathrm{E}-08$ & $9.60 \mathrm{E}-09$ \\
\hline CD115M & $0.00 \mathrm{E}+00$ & $0.00 \mathrm{E}+00$ & $0.00 \mathrm{E}+00$ & $0.00 \mathrm{E}+00$ & $0.00 \mathrm{E}+00$ & $0.00 \mathrm{E}+00$ & $0.00 \mathrm{E}+00$ & $0.00 \mathrm{E}+00$ & $0.00 \mathrm{E}+00$ & $0.00 \mathrm{E}+00$ & $0.00 \mathrm{E}+00$ & $0.00 \mathrm{E}+00$ & $0.00 \mathrm{E}+00$ & $0.00 \mathrm{E}+00$ & $0.00 \mathrm{E}+00$ & $0.00 E+00$ & $0.00 \mathrm{E}+00$ & $0.00 \mathrm{E}+00$ \\
\hline IN115 & 4.04E-04 & $4.35 \mathrm{E}-04$ & 4.67E-04 & $4.93 \mathrm{E}-04$ & $5.14 \mathrm{E}-04$ & $5.30 \mathrm{E}-04$ & $5.40 \mathrm{E}-04$ & $5.46 \mathrm{E}-04$ & $5.48 \mathrm{E}-04$ & $5.45 \mathrm{E}-04$ & $5.38 \mathrm{E}-04$ & $5.27 \mathrm{E}-04$ & $5.11 \mathrm{E}-04$ & 4.89E-04 & $4.61 \mathrm{E}-04$ & $4.27 \mathrm{E}-04$ & $3.85 \mathrm{E}-04$ & $3.40 \mathrm{E}-04$ \\
\hline SN115 & $1.76 \mathrm{E}-05$ & $1.96 \mathrm{E}-05$ & $2.17 \mathrm{E}-05$ & $2.35 \mathrm{E}-05$ & $2.51 \mathrm{E}-05$ & 2.63E-05 & $2.71 \mathrm{E}-05$ & $2.76 \mathrm{E}-05$ & $2.78 \mathrm{E}-05$ & $2.76 \mathrm{E}-05$ & $2.70 \mathrm{E}-05$ & $2.61 \mathrm{E}-05$ & $2.48 \mathrm{E}-05$ & 2.32E-05 & 2.13E-05 & $1.91 \mathrm{E}-05$ & $1.67 \mathrm{E}-05$ & 1.42E-05 \\
\hline CD116 & 4.94E-04 & 5.42E-04 & $5.96 \mathrm{E}-04$ & $6.45 \mathrm{E}-04$ & $6.86 \mathrm{E}-04$ & 7.17E-04 & 7.39E-04 & 7.52E-04 & $7.55 \mathrm{E}-04$ & $7.50 \mathrm{E}-04$ & $7.35 \mathrm{E}-04$ & 7.11E-04 & $6.79 \mathrm{E}-04$ & $6.37 \mathrm{E}-04$ & $5.87 \mathrm{E}-04$ & $5.29 \mathrm{E}-04$ & 4.64E-04 & 4.00E-04 \\
\hline SN116 & $1.02 \mathrm{E}-04$ & $1.27 \mathrm{E}-04$ & $1.56 \mathrm{E}-04$ & $1.83 \mathrm{E}-04$ & $2.06 \mathrm{E}-04$ & $2.26 \mathrm{E}-04$ & $2.40 \mathrm{E}-04$ & $2.48 \mathrm{E}-04$ & $2.51 \mathrm{E}-04$ & $2.47 \mathrm{E}-04$ & $2.38 \mathrm{E}-04$ & 2.23E-04 & $2.03 \mathrm{E}-04$ & $1.79 \mathrm{E}-04$ & $1.52 \mathrm{E}-04$ & $1.23 \mathrm{E}-04$ & $9.41 \mathrm{E}-05$ & $6.76 \mathrm{E}-05$ \\
\hline SN117 & 4.92E-04 & $5.41 \mathrm{E}-04$ & $5.96 \mathrm{E}-04$ & $6.44 \mathrm{E}-04$ & $6.85 \mathrm{E}-04$ & $7.17 \mathrm{E}-04$ & $7.39 \mathrm{E}-04$ & $7.52 \mathrm{E}-04$ & $7.56 \mathrm{E}-04$ & $7.50 \mathrm{E}-04$ & $7.35 \mathrm{E}-04$ & $7.11 \mathrm{E}-04$ & $6.79 \mathrm{E}-04$ & $6.37 \mathrm{E}-04$ & $5.86 \mathrm{E}-04$ & $5.28 \mathrm{E}-04$ & $4.63 \mathrm{E}-04$ & $3.98 \mathrm{E}-04$ \\
\hline SN118 & $5.12 \mathrm{E}-04$ & $5.62 \mathrm{E}-04$ & $6.18 \mathrm{E}-04$ & $6.69 \mathrm{E}-04$ & 7.12E-04 & 7.45E-04 & $7.68 \mathrm{E}-04$ & 7.82E-04 & 7.86E-04 & $7.80 \mathrm{E}-04$ & 7.64E-04 & 7.39E-04 & $7.05 \mathrm{E}-04$ & $6.61 \mathrm{E}-04$ & $6.08 \mathrm{E}-04$ & $5.47 \mathrm{E}-04$ & $4.80 \mathrm{E}-04$ & 4.14E-04 \\
\hline SN119 & $5.08 \mathrm{E}-04$ & $5.58 \mathrm{E}-04$ & $6.14 \mathrm{E}-04$ & $6.65 \mathrm{E}-04$ & $7.08 \mathrm{E}-04$ & $7.41 \mathrm{E}-04$ & $7.64 \mathrm{E}-04$ & $7.77 \mathrm{E}-04$ & $7.81 \mathrm{E}-04$ & $7.76 \mathrm{E}-04$ & $7.60 \mathrm{E}-04$ & $7.35 \mathrm{E}-04$ & $7.01 \mathrm{E}-04$ & $6.57 \mathrm{E}-04$ & $6.04 \mathrm{E}-04$ & $5.44 \mathrm{E}-04$ & $4.77 \mathrm{E}-04$ & 4.11E-04 \\
\hline SN119M & $9.42 E-15$ & $1.04 \mathrm{E}-14$ & 1.15E-14 & $1.25 \mathrm{E}-14$ & $1.34 \mathrm{E}-14$ & $1.41 \mathrm{E}-14$ & 1.45E-14 & $1.48 \mathrm{E}-14$ & 1.49E- 14 & 1.48E-14 & $1.45 \mathrm{E}-14$ & 1.40E-14 & $1.33 \mathrm{E}-14$ & $1.25 \mathrm{E}-14$ & 1.14E-14 & $1.03 \mathrm{E}-14$ & $8.94 \mathrm{E}-15$ & $7.65 \mathrm{E}-15$ \\
\hline $\mathrm{SN} 120$ & $5.21 \mathrm{E}-04$ & $5.72 \mathrm{E}-04$ & $6.29 \mathrm{E}-04$ & $6.80 \mathrm{E}-04$ & $7.24 \mathrm{E}-04$ & $7.57 \mathrm{E}-04$ & $7.81 \mathrm{E}-04$ & $7.94 \mathrm{E}-04$ & $7.98 \mathrm{E}-04$ & $7.93 \mathrm{E}-04$ & $7.77 \mathrm{E}-04$ & $7.51 \mathrm{E}-04$ & $7.17 \mathrm{E}-04$ & $6.72 \mathrm{E}-04$ & $6.19 \mathrm{E}-04$ & $5.57 \mathrm{E}-04$ & $4.89 \mathrm{E}-04$ & 4.22E-04 \\
\hline SN121M & 1.69E-07 & $1.79 \mathrm{E}-07$ & $1.95 \mathrm{E}-07$ & 2.12E-07 & $2.26 \mathrm{E}-07$ & $2.38 \mathrm{E}-07$ & $2.46 \mathrm{E}-07$ & $2.51 \mathrm{E}-07$ & $2.52 \mathrm{E}-07$ & $2.50 \mathrm{E}-07$ & $2.45 \mathrm{E}-07$ & $2.36 \mathrm{E}-07$ & $2.24 \mathrm{E}-07$ & $2.09 \mathrm{E}-07$ & $1.91 \mathrm{E}-07$ & 1.71E-07 & $1.51 \mathrm{E}-07$ & $1.34 \mathrm{E}-07$ \\
\hline
\end{tabular}




\begin{tabular}{|c|c|c|c|c|c|c|c|c|c|c|c|c|c|c|c|c|c|c|}
\hline SB121 & & & & & & & & & & & & & & & & & & \\
\hline & $5.10 \mathrm{E}-04$ & $5.58 \mathrm{E}-04$ & $6.12 E-04$ & $6.60 \mathrm{E}-04$ & $7.01 \mathrm{E}-04$ & $7.32 \mathrm{E}-04$ & $7.54 \mathrm{E}-04$ & $7.66 \mathrm{E}-04$ & $7.70 \mathrm{E}-04$ & $7.65 \mathrm{E}-04$ & $7.50 \mathrm{E}-04$ & $7.26 \mathrm{E}-04$ & $6.94 \mathrm{E}-04$ & $6.53 \mathrm{E}-04$ & $6.02 \mathrm{E}-04$ & $5.44 \mathrm{E}-04$ & $4.79 E-04$ & $4.14 E-04$ \\
\hline SN122 & $5.66 \mathrm{E}-04$ & $6.21 \mathrm{E}-04$ & $6.83 E-04$ & $7.39 \mathrm{E}-04$ & $7.86 \mathrm{E}-04$ & $8.23 \mathrm{E}-04$ & $8.48 \mathrm{E}-04$ & $8.63 E-04$ & $8.67 \mathrm{E}-04$ & $8.61 \mathrm{E}-04$ & $8.44 \mathrm{E}-04$ & $8.16 \mathrm{E}-04$ & $7.79 E-04$ & $7.30 E-04$ & $6.72 \mathrm{E}-04$ & $6.05 \mathrm{E}-04$ & $5.31 \mathrm{E}-04$ & $4.58 \mathrm{E}-04$ \\
\hline TE12 & $1.23 \mathrm{E}-05$ & $1.56 \mathrm{E}-05$ & $1.93 E-05$ & $2.29 E-05$ & $2.61 \mathrm{E}-05$ & $2.88 \mathrm{E}-05$ & $3.08 \mathrm{E}-05$ & $3.20 \mathrm{E}-05$ & $3.23 \mathrm{E}-05$ & $3.18 \mathrm{E}-05$ & $3.05 \mathrm{E}-05$ & $2.84 \mathrm{E}-00$ & $2.56 \mathrm{E}-05$ & $2.24 \mathrm{E}-05$ & $1.87 \mathrm{E}-05$ & $1.50 \mathrm{E}-05$ & $1.13 \mathrm{E}-05$ & $8.02 E-06$ \\
\hline
\end{tabular}
Position=Segment location (midpoint of 2-in. segment) from bottom of fuel (BOF); 2 in. of fuel $~ 14.2 \mathrm{~g}$. 
Table A-1g. Composition (grams) in 2-inch fuel segment: ORIGEN calculation results for Pin195011, decayed to 3/11/2011.

\begin{tabular}{|c|c|c|c|c|c|c|c|c|c|c|c|c|c|c|c|c|c|c|}
\hline Position: & 1 & 3 & 5 & 7 & 9 & 11 & 13 & 15 & 17 & 19 & 21 & 23 & 25 & 27 & 29 & 31 & 33 & 35 \\
\hline SN123 & $2.13 \mathrm{E}-21$ & $2.33 \mathrm{E}-21$ & $2.55 \mathrm{E}-21$ & $2.75 \mathrm{E}-21$ & $2.92 \mathrm{E}-21$ & $3.05 \mathrm{E}-21$ & $3.14 \mathrm{E}-21$ & $3.19 \mathrm{E}-21$ & $3.21 \mathrm{E}-21$ & $3.18 \mathrm{E}-21$ & $3.13 \mathrm{E}-21$ & $3.04 \mathrm{E}-21$ & $2.91 \mathrm{E}-21$ & $2.74 \mathrm{E}-21$ & $2.54 \mathrm{E}-21$ & $2.30 \mathrm{E}-21$ & $2.03 \mathrm{E}-21$ & $1.76 \mathrm{E}-21$ \\
\hline SB123 & $6.06 \mathrm{E}-04$ & $6.63 \mathrm{E}-04$ & $7.29 \mathrm{E}-04$ & $7.88 \mathrm{E}-04$ & $8.37 \mathrm{E}-04$ & $8.76 \mathrm{E}-04$ & $9.02 \mathrm{E}-04$ & $9.18 \mathrm{E}-04$ & $9.22 \mathrm{E}-04$ & $9.16 \mathrm{E}-04$ & $8.98 \mathrm{E}-04$ & $8.69 \mathrm{E}-04$ & $8.30 \mathrm{E}-04$ & $7.79 \mathrm{E}-04$ & $7.18 \mathrm{E}-04$ & $6.47 \mathrm{E}-04$ & $5.68 \mathrm{E}-04$ & $4.90 \mathrm{E}-04$ \\
\hline TE123 & $1.61 \mathrm{E}-07$ & 2.35E-07 & 3.27E- 07 & 4.26E-07 & $5.24 \mathrm{E}-07$ & 6.09E-07 & $6.75 \mathrm{E}-07$ & 7.16E-07 & 7.28E-07 & 7.11E-07 & $6.65 \mathrm{E}-07$ & $5.96 \mathrm{E}-07$ & $5.10 \mathrm{E}-07$ & 4.13E- 07 & $3.15 \mathrm{E}-07$ & 2.23E- 07 & 1.44E-07 & 8.44E- 08 \\
\hline TE123M & $0.00 \mathrm{E}+00$ & $0.00 E+00$ & $4.80 \mathrm{E}-24$ & $7.02 \mathrm{E}-24$ & $8.63 \mathrm{E}-24$ & $0.00 E+00$ & $0.00 E+00$ & $0.00 E+00$ & $0.00 E+00$ & $0.00 \mathrm{E}+00$ & $0.00 \mathrm{E}+00$ & $0.00 E+00$ & $8.43 \mathrm{E}-24$ & $6.83 \mathrm{E}-24$ & 4.65E-24 & $0.00 \mathrm{E}+00$ & $0.00 \mathrm{E}+00$ & $0.00 \mathrm{E}+00$ \\
\hline SN124 & $7.25 \mathrm{E}-04$ & $7.94 \mathrm{E}-04$ & $8.74 \mathrm{E}-04$ & $9.45 \mathrm{E}-04$ & $1.01 \mathrm{E}-03$ & $1.05 \mathrm{E}-03$ & $1.09 \mathrm{E}-03$ & 1.10E-03 & 1.11E-03 & 1.10E-03 & $1.08 \mathrm{E}-03$ & $1.04 \mathrm{E}-03$ & $9.96 \mathrm{E}-04$ & $9.34 \mathrm{E}-04$ & $8.59 \mathrm{E}-04$ & $7.74 \mathrm{E}-04$ & $6.79 \mathrm{E}-04$ & $5.86 \mathrm{E}-04$ \\
\hline SB124 & $3.08 \mathrm{E}-39$ & $3.88 \mathrm{E}-39$ & $4.78 \mathrm{E}-39$ & $5.66 \mathrm{E}-39$ & $6.45 \mathrm{E}-39$ & 7.10E-39 & $7.58 \mathrm{E}-39$ & $7.87 \mathrm{E}-39$ & $7.96 \mathrm{E}-39$ & $7.84 \mathrm{E}-39$ & $7.52 \mathrm{E}-39$ & $7.02 \mathrm{E}-39$ & $6.37 \mathrm{E}-39$ & $5.57 \mathrm{E}-39$ & 4.69E-39 & $3.77 \mathrm{E}-39$ & $2.86 \mathrm{E}-39$ & 2.05E-39 \\
\hline TE124 & $8.25 \mathrm{E}-06$ & 1.03E-05 & 1.27E- 05 & $1.50 \mathrm{E}-05$ & $1.71 \mathrm{E}-05$ & 1.88E-05 & 2.00E-05 & 2.08E-05 & 2.10E- 05 & 2.07E- 05 & $1.98 \mathrm{E}-05$ & $1.85 \mathrm{E}-05$ & 1.67E-05 & 1.46E- 05 & 1.23E-05 & $9.91 \mathrm{E}-06$ & 7.55E-06 & $5.46 \mathrm{E}-06$ \\
\hline SN125 & $0.00 \mathrm{E}+00$ & $0.00 \mathrm{E}+00$ & $0.00 E+00$ & $0.00 E+00$ & $0.00 \mathrm{E}+00$ & $0.00 E+00$ & $0.00 E+00$ & $0.00 \mathrm{E}+00$ & $0.00 \mathrm{E}+00$ & $0.00 E+00$ & $0.00 \mathrm{E}+00$ & $0.00 E+00$ & $0.00 E+00$ & $0.00 \mathrm{E}+00$ & $0.00 \mathrm{E}+00$ & $0.00 \mathrm{E}+00$ & $0.00 \mathrm{E}+00$ & $0.00 \mathrm{E}+00$ \\
\hline SB125 & $5.75 \mathrm{E}-06$ & $6.29 \mathrm{E}-06$ & $6.92 \mathrm{E}-06$ & $7.48 \mathrm{E}-06$ & $7.95 \mathrm{E}-06$ & $8.32 \mathrm{E}-06$ & $8.57 \mathrm{E}-06$ & $8.72 \mathrm{E}-06$ & $8.77 \mathrm{E}-06$ & $8.71 \mathrm{E}-06$ & $8.54 \mathrm{E}-06$ & $8.26 \mathrm{E}-06$ & $7.88 \mathrm{E}-06$ & $7.40 \mathrm{E}-06$ & $6.82 \mathrm{E}-06$ & $6.14 \mathrm{E}-06$ & $5.39 \mathrm{E}-06$ & 4.66E-06 \\
\hline TE125 & $8.55 \mathrm{E}-04$ & $9.35 \mathrm{E}-04$ & $1.03 \mathrm{E}-03$ & 1.11E-03 & 1.18E-03 & 1.24E-03 & $1.28 \mathrm{E}-03$ & 1.30E-03 & $1.31 \mathrm{E}-03$ & $1.30 \mathrm{E}-03$ & $1.27 \mathrm{E}-03$ & $1.23 \mathrm{E}-03$ & 1.17E-03 & 1.10E-03 & $1.01 \mathrm{E}-03$ & $9.11 \mathrm{E}-04$ & $7.99 \mathrm{E}-04$ & $6.90 \mathrm{E}-04$ \\
\hline TE125M & $8.04 \mathrm{E}-08$ & $8.80 \mathrm{E}-08$ & $9.68 \mathrm{E}-08$ & $1.05 \mathrm{E}-07$ & $1.11 \mathrm{E}-07$ & 1.16E-07 & $1.20 \mathrm{E}-07$ & 1.22E-07 & $1.23 \mathrm{E}-07$ & $1.22 \mathrm{E}-07$ & $1.19 \mathrm{E}-07$ & 1.16E-07 & $1.10 \mathrm{E}-07$ & $1.04 \mathrm{E}-07$ & $9.53 \mathrm{E}-08$ & $8.59 \mathrm{E}-08$ & $7.54 \mathrm{E}-08$ & $6.52 \mathrm{E}-08$ \\
\hline SN126 & $1.23 \mathrm{E}-03$ & $1.34 \mathrm{E}-03$ & $1.47 \mathrm{E}-03$ & $1.59 \mathrm{E}-03$ & $1.70 \mathrm{E}-03$ & $1.78 \mathrm{E}-03$ & $1.83 \mathrm{E}-03$ & $1.87 \mathrm{E}-03$ & $1.88 \mathrm{E}-03$ & $1.86 \mathrm{E}-03$ & $1.82 \mathrm{E}-03$ & $1.76 \mathrm{E}-03$ & $1.68 \mathrm{E}-03$ & 1.57E-03 & 1.45E-03 & $1.30 \mathrm{E}-03$ & $1.14 \mathrm{E}-03$ & $9.94 \mathrm{E}-04$ \\
\hline SB126 & $5.86 \mathrm{E}-11$ & $6.37 \mathrm{E}-11$ & $7.00 \mathrm{E}-11$ & $7.57 \mathrm{E}-11$ & $8.06 \mathrm{E}-11$ & $8.44 \mathrm{E}-11$ & $8.71 \mathrm{E}-11$ & $8.86 \mathrm{E}-11$ & $8.91 \mathrm{E}-11$ & $8.84 \mathrm{E}-11$ & $8.66 \mathrm{E}-11$ & $8.37 \mathrm{E}-11$ & $7.98 \mathrm{E}-11$ & $7.48 \mathrm{E}-11$ & $6.87 \mathrm{E}-11$ & $6.19 \mathrm{E}-11$ & $5.43 \mathrm{E}-11$ & $4.72 \mathrm{E}-11$ \\
\hline TE126 & $4.48 \mathrm{E}-05$ & $5.03 \mathrm{E}-05$ & $5.72 \mathrm{E}-05$ & $6.40 \mathrm{E}-05$ & $6.99 \mathrm{E}-05$ & $7.47 \mathrm{E}-05$ & $7.82 \mathrm{E}-05$ & $8.03 \mathrm{E}-05$ & $8.09 \mathrm{E}-05$ & $8.00 \mathrm{E}-05$ & $7.77 \mathrm{E}-05$ & 7.39E-05 & $6.90 \mathrm{E}-05$ & $6.29 \mathrm{E}-05$ & $5.59 \mathrm{E}-05$ & $4.84 \mathrm{E}-05$ & $4.08 \mathrm{E}-05$ & $3.41 \mathrm{E}-05$ \\
\hline TE127 & $1.74 \mathrm{E}-26$ & $1.88 \mathrm{E}-26$ & 3.22E- 26 & 3.46E-26 & $3.67 \mathrm{E}-26$ & $3.83 \mathrm{E}-26$ & $3.94 \mathrm{E}-26$ & $4.01 \mathrm{E}-26$ & 4.03E-26 & $4.01 \mathrm{E}-26$ & $3.94 \mathrm{E}-26$ & $3.82 \mathrm{E}-26$ & $3.66 \mathrm{E}-26$ & $3.45 \mathrm{E}-26$ & $3.19 \mathrm{E}-26$ & $1.85 \mathrm{E}-26$ & $1.64 \mathrm{E}-26$ & 1.44E-26 \\
\hline TE127M & $0.00 \mathrm{E}+00$ & $0.00 \mathrm{E}+00$ & $9.20 \mathrm{E}-24$ & $9.91 \mathrm{E}-24$ & $1.05 \mathrm{E}-23$ & 1.10E-23 & 1.13E- 23 & 1.15E-23 & 1.15E-23 & 1.15E-23 & 1.13E- 23 & $1.09 \mathrm{E}-23$ & $1.05 \mathrm{E}-23$ & $9.86 \mathrm{E}-24$ & $9.13 \mathrm{E}-24$ & $0.00 \mathrm{E}+00$ & $0.00 \mathrm{E}+00$ & $0.00 \mathrm{E}+00$ \\
\hline I127 & $2.18 \mathrm{E}-03$ & $2.34 \mathrm{E}-03$ & $2.56 \mathrm{E}-03$ & $2.76 \mathrm{E}-03$ & $2.93 \mathrm{E}-03$ & $3.06 \mathrm{E}-03$ & 3.16E-03 & $3.21 \mathrm{E}-03$ & 3.23E-03 & $3.20 \mathrm{E}-03$ & $3.14 \mathrm{E}-03$ & $3.04 \mathrm{E}-03$ & $2.90 \mathrm{E}-03$ & $2.73 \mathrm{E}-03$ & $2.51 \mathrm{E}-03$ & $2.27 \mathrm{E}-03$ & $2.01 \mathrm{E}-03$ & $1.76 \mathrm{E}-03$ \\
\hline TE128 & $4.04 \mathrm{E}-03$ & $4.35 \mathrm{E}-03$ & $4.75 \mathrm{E}-03$ & $5.13 \mathrm{E}-03$ & $5.46 \mathrm{E}-03$ & $5.71 \mathrm{E}-03$ & $5.89 \mathrm{E}-03$ & $5.99 \mathrm{E}-03$ & $6.02 \mathrm{E}-03$ & $5.98 \mathrm{E}-03$ & $5.86 \mathrm{E}-03$ & $5.66 \mathrm{E}-03$ & $5.40 \mathrm{E}-03$ & $5.07 \mathrm{E}-03$ & 4.66E-03 & $4.21 \mathrm{E}-03$ & $3.71 \mathrm{E}-03$ & 3.26E-03 \\
\hline XE128 & $5.19 \mathrm{E}-05$ & $6.46 \mathrm{E}-05$ & $7.96 \mathrm{E}-05$ & $9.45 \mathrm{E}-05$ & $1.08 \mathrm{E}-04$ & 1.19E-04 & $1.28 \mathrm{E}-04$ & 1.33E-04 & $1.34 \mathrm{E}-04$ & $1.32 \mathrm{E}-04$ & $1.26 \mathrm{E}-04$ & 1.18E-04 & $1.06 \mathrm{E}-04$ & $9.23 \mathrm{E}-05$ & $7.73 \mathrm{E}-05$ & $6.17 \mathrm{E}-05$ & 4.67E-05 & 3.36E-05 \\
\hline TE129 & $0.00 \mathrm{E}+00$ & $0.00 \mathrm{E}+00$ & $0.00 \mathrm{E}+00$ & $0.00 \mathrm{E}+00$ & $0.00 E+00$ & $0.00 E+00$ & $0.00 E+00$ & $0.00 \mathrm{E}+00$ & $0.00 E+00$ & $0.00 \mathrm{E}+00$ & $0.00 \mathrm{E}+00$ & $0.00 \mathrm{E}+00$ & $0.00 E+00$ & $0.00 \mathrm{E}+00$ & $0.00 \mathrm{E}+00$ & $0.00 E+00$ & $0.00 \mathrm{E}+00$ & $0.00 \mathrm{E}+00$ \\
\hline TE129M & $0.00 \mathrm{E}+00$ & $0.00 \mathrm{E}+00$ & $0.00 E+00$ & $0.00 \mathrm{E}+00$ & $0.00 \mathrm{E}+00$ & $0.00 \mathrm{E}+00$ & $0.00 \mathrm{E}+00$ & $0.00 \mathrm{E}+00$ & $0.00 E+00$ & $0.00 \mathrm{E}+00$ & $0.00 \mathrm{E}+00$ & $0.00 E+00$ & $0.00 E+00$ & $0.00 \mathrm{E}+00$ & $0.00 E+00$ & $0.00 E+00$ & $0.00 \mathrm{E}+00$ & $0.00 \mathrm{E}+00$ \\
\hline
\end{tabular}




\begin{tabular}{|c|c|c|c|c|c|c|c|c|c|c|c|c|c|c|c|c|c|c|}
\hline 1129 & & & & & & & & & & & & & & & & & & \\
\hline & $5.93 \mathrm{E}-03$ & $6.35 \mathrm{E}-03$ & $6.93 E-03$ & $7.47 \mathrm{E}-03$ & $7.93 \mathrm{E}-03$ & $8.30 \mathrm{E}-03$ & $8.55 \mathrm{E}-03$ & $8.70 E-03$ & $8.74 \mathrm{E}-03$ & $8.68 \mathrm{E}-03$ & $8.51 \mathrm{E}-03$ & $8.23 \mathrm{E}-03$ & $7.85 E-03$ & $7.37 E-03$ & $6.80 \mathrm{E}-03$ & $6.14 \mathrm{E}-03$ & $5.42 E-03$ & $4.78 E-03$ \\
\hline XE129 & $3.24 \mathrm{E}-07$ & $4.56 \mathrm{E}-07$ & $6.23 E-07$ & $8.05 \mathrm{E}-07$ & $9.83 \mathrm{E}-07$ & 1.14E-06 & $1.26 \mathrm{E}-06$ & $1.34 E-06$ & $1.36 \mathrm{E}-06$ & $1.33 \mathrm{E}-06$ & $1.24 \mathrm{E}-06$ & $1.12 \mathrm{E}-06$ & $9.57 \mathrm{e}-07$ & $7.79 E-07$ & $5.99 \mathrm{E}-07$ & $4.31 E-07$ & $2.87 \mathrm{E}-07$ & $1.78 \mathrm{E}-07$ \\
\hline TE13 & $1.05 \mathrm{E}-02$ & $1.13 \mathrm{E}-02$ & $1.23 \mathrm{E}-02$ & $1.33 \mathrm{E}-02$ & $1.42 \mathrm{E}-02$ & $1.48 \mathrm{E}-02$ & $1.53 \mathrm{E}-02$ & $1.56 \mathrm{E}-02$ & $1.56 \mathrm{E}-02$ & $1.55 \mathrm{E}-02$ & $1.52 \mathrm{E}-02$ & $1.47 \mathrm{E}-02$ & $1.40 \mathrm{E}-02$ & $1.31 \mathrm{E}-02$ & $1.21 \mathrm{E}-02$ & $1.09 \mathrm{E}-02$ & $9.61 \mathrm{E}-03$ & $8.46 \mathrm{E}-03$ \\
\hline
\end{tabular}
Position=Segment location (midpoint of 2-in. segment) from bottom of fuel (BOF); 2 in. of fuel $\sim 14.2 \mathrm{~g}$ 
Table A-1h. Composition (grams) in 2-inch fuel segment: ORIGEN calculation results for Pin195011, decayed to 3/11/2011.

\begin{tabular}{|c|c|c|c|c|c|c|c|c|c|c|c|c|c|c|c|c|c|c|}
\hline Position: & 1 & 3 & 5 & 7 & 9 & 11 & 13 & 15 & 17 & 19 & 21 & 23 & 25 & 27 & 29 & 31 & 33 & 35 \\
\hline XE130 & 1.26E-04 & $1.56 \mathrm{E}-04$ & $1.92 \mathrm{E}-04$ & 2.27E-04 & $2.60 \mathrm{E}-04$ & $2.86 \mathrm{E}-04$ & $3.06 \mathrm{E}-04$ & $3.18 \mathrm{E}-04$ & $3.22 \mathrm{E}-04$ & $3.17 \mathrm{E}-04$ & $3.03 E-04$ & 2.82E-04 & $2.55 \mathrm{E}-04$ & $2.22 \mathrm{E}-04$ & $1.86 \mathrm{E}-04$ & $1.49 \mathrm{E}-04$ & 1.13E-04 & $8.20 \mathrm{E}-05$ \\
\hline $\mid 131$ & $0.00 \mathrm{E}+00$ & $0.00 \mathrm{E}+00$ & $0.00 \mathrm{E}+00$ & $0.00 \mathrm{E}+00$ & $0.00 \mathrm{E}+00$ & $0.00 \mathrm{E}+00$ & $0.00 \mathrm{E}+00$ & $0.00 \mathrm{E}+00$ & $0.00 \mathrm{E}+00$ & $0.00 \mathrm{E}+00$ & $0.00 \mathrm{E}+00$ & $0.00 \mathrm{E}+00$ & $0.00 \mathrm{E}+00$ & $0.00 \mathrm{E}+00$ & $0.00 \mathrm{E}+00$ & $0.00 \mathrm{E}+00$ & $0.00 \mathrm{E}+00$ & $0.00 \mathrm{E}+00$ \\
\hline XE131 & $1.73 \mathrm{E}-02$ & $84 \mathrm{E}-02$ & $2.01 \mathrm{E}-02$ & $2.17 \mathrm{E}-02$ & $2.30 \mathrm{E}-02$ & $2.41 \mathrm{E}-02$ & $2.48 \mathrm{E}-02$ & $2.53 \mathrm{E}-02$ & $2.54 \mathrm{E}-02$ & 2.52E-02 & $2.47 \mathrm{E}-02$ & 2.39E-02 & $2.28 \mathrm{E}-02$ & 2.14E-02 & $1.97 \mathrm{E}-02$ & 1.78E-02 & $1.57 \mathrm{E}-02$ & 1.39E-02 \\
\hline XE131M & $0.00 \mathrm{E}+00$ & $0.00 \mathrm{E}+00$ & $0.00 \mathrm{E}+00$ & $0.00 \mathrm{E}+00$ & $0.00 \mathrm{E}+00$ & $0.00 \mathrm{E}+00$ & $0.00 \mathrm{E}+00$ & $0.00 \mathrm{E}+00$ & $0.00 \mathrm{E}+00$ & $0.00 \mathrm{E}+00$ & $0.00 \mathrm{E}+00$ & $0.00 \mathrm{E}+00$ & $0.00 \mathrm{E}+00$ & $0.00 \mathrm{E}+00$ & $0.00 \mathrm{E}+00$ & $0.00 E+00$ & $0.00 \mathrm{E}+00$ & $0.00 \mathrm{E}+00$ \\
\hline XE132 & $2.50 \mathrm{E}-02$ & $2.68 \mathrm{E}-02$ & $2.93 \mathrm{E}-02$ & 3.16E-02 & 3.36E-02 & 3.52E-02 & 3.63E-02 & $3.70 \mathrm{E}-02$ & 3.72E- 02 & 3.69E-02 & $3.61 \mathrm{E}-02$ & 3.49E-02 & 3.33E- 02 & 3.12E-02 & 2.87E-02 & 2.58E-02 & 2.28E-02 & $2.01 \mathrm{E}-02$ \\
\hline BA132 & $1.87 \mathrm{E}-08$ & $2.31 \mathrm{E}-08$ & $83 \mathrm{E}-08$ & $3.36 \mathrm{E}-08$ & $3.84 \mathrm{E}-08$ & $24 \mathrm{E}-08$ & $54 \mathrm{E}-08$ & $4.71 \mathrm{E}-08$ & $4.76 \mathrm{E}-08$ & 4.69E-08 & $4.49 \mathrm{E}-08$ & 4.17E-08 & $3.77 \mathrm{E}-08$ & $3.28 \mathrm{E}-08$ & $2.75 \mathrm{E}-08$ & $2.20 \mathrm{E}-08$ & 1.67E-08 & $1.21 \mathrm{E}-08$ \\
\hline XE133 & $0.00 \mathrm{E}+00$ & $0.00 \mathrm{E}+00$ & $0.00 \mathrm{E}+00$ & $0.00 \mathrm{E}+00$ & $0.00 \mathrm{E}+00$ & $0.00 \mathrm{E}+00$ & $0.00 \mathrm{E}+00$ & $0.00 \mathrm{E}+00$ & $0.00 \mathrm{E}+00$ & $0.00 \mathrm{E}+00$ & $0.00 \mathrm{E}+00$ & $0.00 \mathrm{E}+00$ & $0.00 \mathrm{E}+00$ & $0.00 \mathrm{E}+00$ & $0.00 \mathrm{E}+00$ & $0.00 \mathrm{E}+00$ & $0.00 \mathrm{E}+00$ & $0.00 \mathrm{E}+00$ \\
\hline CS133 & $3.40 \mathrm{E}-02$ & $3.62 \mathrm{E}-02$ & $3.93 \mathrm{E}-02$ & $4.23 \mathrm{E}-02$ & $4.48 \mathrm{E}-02$ & $4.68 \mathrm{E}-02$ & $4.82 \mathrm{E}-02$ & $4.90 \mathrm{E}-02$ & $4.93 \mathrm{E}-02$ & $4.89 \mathrm{E}-02$ & $4.80 \mathrm{E}-02$ & $4.65 \mathrm{E}-02$ & $4.44 \mathrm{E}-02$ & 4.17E- 02 & $3.85 \mathrm{E}-02$ & $3.49 \mathrm{E}-02$ & 3.10E-02 & $2.75 \mathrm{E}-02$ \\
\hline XE134 & 4.08E-02 & 4.35E-02 & 4.74E-02 & 5.11E-02 & 5.43E-02 & 5.68E-02 & $5.86 \mathrm{E}-02$ & $5.96 \mathrm{E}-02$ & 5.99E-02 & 5.95E-02 & 5.83E-02 & 5.64E-02 & 5.37E- 02 & $5.04 \mathrm{E}-02$ & 4.65E-02 & 4.19E-02 & $3.71 \mathrm{E}-02$ & 3.29E-02 \\
\hline CS134 & $1.24 \mathrm{E}-06$ & $1.52 \mathrm{E}-06$ & $1.86 \mathrm{E}-06$ & $2.20 \mathrm{E}-06$ & $2.51 \mathrm{E}-06$ & $2.76 \mathrm{E}-06$ & $2.95 \mathrm{E}-06$ & $3.06 \mathrm{E}-06$ & $3.10 \mathrm{E}-06$ & $3.05 \mathrm{E}-06$ & $2.92 \mathrm{E}-06$ & $2.72 E-06$ & $2.46 \mathrm{E}-06$ & $2.15 \mathrm{E}-06$ & $1.80 \mathrm{E}-06$ & $1.45 \mathrm{E}-06$ & $1.10 \mathrm{E}-06$ & $8.04 \mathrm{E}-07$ \\
\hline BA134 & $9.04 \mathrm{E}-04$ & $1.11 \mathrm{E}-03$ & $1.36 \mathrm{E}-03$ & 1.61E-03 & $1.84 \mathrm{E}-03$ & $2.03 \mathrm{E}-03$ & $2.16 \mathrm{E}-03$ & $2.25 \mathrm{E}-03$ & $2.27 \mathrm{E}-03$ & $2.24 \mathrm{E}-03$ & 2.14E-03 & 1.99E-03 & $1.80 \mathrm{E}-03$ & $1.57 \mathrm{E}-03$ & $1.32 \mathrm{E}-03$ & $1.06 \mathrm{E}-03$ & $8.04 \mathrm{E}-04$ & $5.87 \mathrm{E}-04$ \\
\hline CS135 & 3.44E-02 & 3.67E-02 & 4.01E-02 & 4.32E-02 & 4.60E-02 & 4.81E-02 & $4.96 \mathrm{E}-02$ & $5.05 \mathrm{E}-02$ & $5.08 \mathrm{E}-02$ & 5.04E-02 & 4.94E-02 & 4.77E-02 & 4.55E-02 & 4.26E-02 & $3.93 \mathrm{E}-02$ & 3.54E-02 & 3.13E-02 & $2.76 \mathrm{E}-02$ \\
\hline BA13 & $8.31 \mathrm{E}-07$ & 1.10E-06 & $1.45 \mathrm{E}-06$ & $1.83 \mathrm{E}-06$ & $2.20 \mathrm{E}-06$ & $2.53 \mathrm{E}-06$ & $2.78 \mathrm{E}-06$ & $2.93 \mathrm{E}-06$ & $2.98 \mathrm{E}-06$ & $2.91 \mathrm{E}-06$ & 2.73E-06 & $2.47 \mathrm{E}-06$ & 2.14E- 06 & 1.77E-06 & 1.39E- 06 & $1.04 \mathrm{E}-06$ & $7.29 \mathrm{E}-07$ & $4.96 \mathrm{E}-07$ \\
\hline XE136 & $3.48 \mathrm{E}-02$ & $3.72 \mathrm{E}-02$ & 4.06E-02 & 4.38E-02 & $4.65 \mathrm{E}-02$ & $4.87 \mathrm{E}-02$ & $5.02 \mathrm{E}-02$ & $5.11 \mathrm{E}-02$ & $5.14 \mathrm{E}-02$ & $5.10 \mathrm{E}-02$ & 4.99E-02 & $4.83 \mathrm{E}-02$ & $4.60 \mathrm{E}-02$ & 4.32E-02 & $3.97 \mathrm{E}-02$ & $3.58 \mathrm{E}-02$ & $3.17 \mathrm{E}-02$ & $2.80 \mathrm{E}-02$ \\
\hline CS136 & $0.00 \mathrm{E}+00$ & $0.00 E+00$ & $0.00 E+00$ & $0.00 E+00$ & $0.00 E+00$ & $0.00 \mathrm{E}+00$ & $0.00 E+00$ & $0.00 E+00$ & $0.00 \mathrm{E}+00$ & $0.00 E+00$ & $0.00 \mathrm{E}+00$ & $0.00 \mathrm{E}+00$ & $0.00 E+00$ & $0.00 \mathrm{E}+00$ & $0.00 E+00$ & $0.00 \mathrm{E}+00$ & $0.00 \mathrm{E}+00$ & $0.00 E+00$ \\
\hline BA136 & $2.76 \mathrm{E}-04$ & $3.14 \mathrm{E}-04$ & $3.65 \mathrm{E}-04$ & 4.15E-04 & $4.60 \mathrm{E}-04$ & $4.97 \mathrm{E}-04$ & $5.25 \mathrm{E}-04$ & $5.41 \mathrm{E}-04$ & $5.46 \mathrm{E}-04$ & $5.39 \mathrm{E}-04$ & $5.20 \mathrm{E}-04$ & 4.91E-04 & 4.52E-04 & $4.06 \mathrm{E}-04$ & $3.54 \mathrm{E}-04$ & $3.00 \mathrm{E}-04$ & $2.46 \mathrm{E}-04$ & $2.01 \mathrm{E}-04$ \\
\hline CS13 & $2.08 \mathrm{E}-02$ & 2.22E-02 & 2.42E-02 & 2.61E-02 & $2.77 \mathrm{E}-02$ & $2.90 \mathrm{E}-02$ & $2.99 \mathrm{E}-02$ & $3.04 \mathrm{E}-02$ & $3.06 \mathrm{E}-02$ & $3.04 \mathrm{E}-02$ & $2.98 \mathrm{E}-02$ & 2.88E-02 & $2.74 \mathrm{E}-02$ & $2.57 \mathrm{E}-02$ & $2.37 \mathrm{E}-02$ & 2.14E-02 & 1.89E-02 & $1.67 \mathrm{E}-02$ \\
\hline BA137 & 1.23E- 02 & $1.31 \mathrm{E}-02$ & 1.43E-02 & 1.54E-02 & 1.64E-02 & $1.71 \mathrm{E}-02$ & $1.77 \mathrm{E}-02$ & $1.80 \mathrm{E}-02$ & 1.81E-02 & 1.80E-02 & $1.76 \mathrm{E}-02$ & 1.70E-02 & 1.62E-02 & 1.52E-02 & 1.40E-02 & 1.26E-02 & 1.12E-02 & 9.87E-03 \\
\hline BA138 & 3.58E-02 & $3.81 \mathrm{E}-02$ & 4.16E-02 & 4.49E- 02 & $4.77 \mathrm{E}-02$ & 4.99E-02 & $5.14 \mathrm{E}-02$ & $5.23 \mathrm{E}-02$ & $5.26 \mathrm{E}-02$ & $5.22 \mathrm{E}-02$ & $5.12 \mathrm{E}-02$ & $4.95 \mathrm{E}-02$ & $4.72 \mathrm{E}-02$ & $4.42 \mathrm{E}-02$ & $4.08 \mathrm{E}-02$ & 3.68E-02 & $3.25 \mathrm{E}-02$ & $2.88 \mathrm{E}-02$ \\
\hline LA138 & $1.42 \mathrm{E}-07$ & $1.49 \mathrm{E}-07$ & 1.62E-07 & $1.74 \mathrm{E}-07$ & $1.84 \mathrm{E}-07$ & $1.92 \mathrm{E}-07$ & $1.98 \mathrm{E}-07$ & $2.01 \mathrm{E}-07$ & $2.02 E-07$ & $2.01 \mathrm{E}-07$ & $1.97 \mathrm{E}-07$ & $1.91 \mathrm{E}-07$ & $1.82 \mathrm{E}-07$ & $1.71 \mathrm{E}-07$ & $1.58 \mathrm{E}-07$ & 1.43E-07 & 1.28E-07 & 1.14E- -07 \\
\hline LA139 & $3.49 \mathrm{E}-02$ & $3.71 \mathrm{E}-02$ & 4.05E-02 & 4.37E-02 & 4.64E-02 & $4.85 \mathrm{E}-02$ & $5.00 \mathrm{E}-02$ & $5.09 \mathrm{E}-02$ & $5.11 \mathrm{E}-02$ & $5.08 \mathrm{E}-02$ & 4.98E-02 & $4.81 \mathrm{E}-02$ & $4.59 \mathrm{E}-02$ & 4.31E-02 & $3.97 \mathrm{E}-02$ & $3.58 \mathrm{E}-02$ & 3.17E-02 & $2.81 \mathrm{E}-02$ \\
\hline
\end{tabular}




\begin{tabular}{|c|c|c|c|c|c|c|c|c|c|c|c|c|c|c|c|c|c|c|}
\hline BA140 & $0.00 E+00$ & $0.00 \mathrm{E}+00$ & $0.00 \mathrm{E}+00$ & $0.00 E+00$ & $0.00 \mathrm{E}+00$ & $0.00 \mathrm{E}+00$ & $0.00 \mathrm{E}+00$ & $0.00 \mathrm{E}+00$ & $0.00 E+00$ & $0.00 E+00$ & $0.00 E+00$ & $0.00 \mathrm{E}+00$ & $0.00 \mathrm{E}+00$ & $0.00 E+00$ & $0.00 \mathrm{E}+00$ & $0.00 E+00$ & $0.00 \mathrm{E}+00$ & $0.00 E+00$ \\
\hline LA140 & $0.00 \mathrm{E}+00$ & $0.00 \mathrm{E}+00$ & $0.00 \mathrm{E}+00$ & $0.00 \mathrm{E}+00$ & $0.00 \mathrm{E}+00$ & $0.00 \mathrm{E}+00$ & $0.00 \mathrm{E}+00$ & $0.00 E+00$ & $0.00 \mathrm{E}+00$ & $0.00 \mathrm{E}+00$ & $0.00 \mathrm{E}+00$ & $0.00 \mathrm{E}+00$ & $0.00 \mathrm{E}+00$ & $0.00 \mathrm{E}+00$ & $0.00 \mathrm{E}+00$ & $0.00 \mathrm{E}+00$ & $0.00 \mathrm{E}+00$ & $0.00 \mathrm{E}+00$ \\
\hline CE140 & 3.40E-02 & 3.63E-02 & $3.95 \mathrm{E}-02$ & 4.26E-02 & 4.53E-02 & $4.74 \mathrm{E}-02$ & 4.88E-02 & 4.97E-02 & 4.99E-02 & $4.96 \mathrm{E}-02$ & $4.86 \mathrm{E}-02$ & $4.70 \mathrm{E}-02$ & $4.48 \mathrm{E}-02$ & $4.20 \mathrm{E}-02$ & $3.87 \mathrm{E}-02$ & $3.50 \mathrm{E}-02$ & $3.09 \mathrm{E}-02$ & $2.74 \mathrm{E}-02$ \\
\hline
\end{tabular}
Position=Segment location (midpoint of 2-in. segment) from bottom of fuel (BOF); 2 in. of fuel $~ 14.2 \mathrm{~g}$. 
Table A-1i. Composition (grams) in 2-inch fuel segment: ORIGEN calculation results for Pin195011, decayed to 3/11/2011.

\begin{tabular}{|c|c|c|c|c|c|c|c|c|c|c|c|c|c|c|c|c|c|c|}
\hline Position: & 1 & 3 & 5 & 7 & 9 & 11 & 13 & 15 & 17 & 19 & 21 & 23 & 25 & 27 & 29 & 31 & 33 & 35 \\
\hline CE141 & $0.00 \mathrm{E}+00$ & $0.00 \mathrm{E}+00$ & $0.00 \mathrm{E}+00$ & $0.00 \mathrm{E}+00$ & $0.00 \mathrm{E}+00$ & $0.00 \mathrm{E}+00$ & $0.00 \mathrm{E}+00$ & $0.00 \mathrm{E}+00$ & $0.00 \mathrm{E}+00$ & $0.00 \mathrm{E}+00$ & $0.00 \mathrm{E}+00$ & $0.00 \mathrm{E}+00$ & $0.00 \mathrm{E}+00$ & $0.00 \mathrm{E}+00$ & $0.00 \mathrm{E}+00$ & $0.00 \mathrm{E}+00$ & $0.00 \mathrm{E}+00$ & $0.00 \mathrm{E}+00$ \\
\hline PR141 & $3.31 \mathrm{E}-02$ & 3.52E-02 & 3.83E-02 & 4.13E- 02 & 4.38E-02 & 4.58E-02 & 4.72E- 02 & $4.81 \mathrm{E}-02$ & 4.83E-02 & $4.80 \mathrm{E}-02$ & 4.70E-02 & 4.55E-02 & 4.34E-02 & 4.07E-02 & $3.76 \mathrm{E}-02$ & 3.39E-02 & $3.00 \mathrm{E}-02$ & 2.67E-02 \\
\hline CE142 & 3.12E-02 & 3.33E-02 & $3.62 \mathrm{E}-02$ & $3.91 \mathrm{E}-02$ & 4.15E-02 & 4.34E- 02 & 4.47E- 02 & $4.55 \mathrm{E}-02$ & 4.58E-02 & 4.54E-02 & 4.45E-02 & 4.31E-02 & 4.11E-02 & $3.85 \mathrm{E}-02$ & 3.55E-02 & $3.21 \mathrm{E}-02$ & $2.84 \mathrm{E}-02$ & $2.51 \mathrm{E}-02$ \\
\hline ND142 & 2.33E-04 & 2.87E-04 & 3.53E-04 & 4. $18 \mathrm{E}-04$ & 4.79E-04 & 5.29E-04 & $5.66 \mathrm{E}-04$ & $5.88 \mathrm{E}-04$ & $5.95 \mathrm{E}-04$ & $5.85 \mathrm{E}-04$ & 5.60E-04 & $5.21 \mathrm{E}-04$ & 4.69E-04 & $4.08 \mathrm{E}-04$ & $3.41 \mathrm{E}-04$ & $2.73 \mathrm{E}-04$ & 2.07E-04 & $1.51 \mathrm{E}-04$ \\
\hline PR143 & $0.00 \mathrm{E}+00$ & $0.00 \mathrm{E}+00$ & $0.00 \mathrm{E}+00$ & $0.00 \mathrm{E}+00$ & $0.00 \mathrm{E}+00$ & $0.00 \mathrm{E}+00$ & $0.00 \mathrm{E}+00$ & $0.00 \mathrm{E}+00$ & $0.00 \mathrm{E}+00$ & $0.00 \mathrm{E}+00$ & $0.00 \mathrm{E}+00$ & $0.00 \mathrm{E}+00$ & $0.00 \mathrm{E}+00$ & $0.00 \mathrm{E}+00$ & $0.00 \mathrm{E}+00$ & $0.00 \mathrm{E}+00$ & $0.00 \mathrm{E}+00$ & $0.00 \mathrm{E}+00$ \\
\hline ND143 & $3.16 \mathrm{E}-02$ & 3.35E-02 & 3.64E-02 & 3.92E-02 & 4.15E-02 & 4.34E-02 & 4.47E- 02 & $4.55 \mathrm{E}-02$ & 4.57E-02 & 4.54E-02 & 4.45E-02 & 4.31E-02 & 4.11E-02 & 3.87E-02 & 3.57E-02 & $3.23 \mathrm{E}-02$ & $2.87 \mathrm{E}-02$ & $2.55 \mathrm{E}-02$ \\
\hline CE144 & $5.93 \mathrm{E}-10$ & $6.31 \mathrm{E}-10$ & $6.85 \mathrm{E}-10$ & $7.36 \mathrm{E}-10$ & $7.79 \mathrm{E}-10$ & $8.13 \mathrm{E}-10$ & $8.37 E-10$ & $8.51 \mathrm{E}-10$ & $8.55 \mathrm{E}-10$ & $8.49 \mathrm{E}-10$ & $8.34 \mathrm{E}-10$ & $8.09 \mathrm{E}-10$ & $7.74 \mathrm{E}-10$ & $7.30 \mathrm{E}-10$ & $6.76 \mathrm{E}-10$ & $6.13 \mathrm{E}-10$ & $5.45 \mathrm{E}-10$ & $4.85 \mathrm{E}-10$ \\
\hline PR144 & $2.50 \mathrm{E}-14$ & $2.66 \mathrm{E}-14$ & 2.89E-14 & 3.11E-14 & 3.29E-14 & 3.43E-14 & 3.53E-14 & 3.59E-14 & $3.61 \mathrm{E}-14$ & 3.59E-14 & 3.52E-14 & 3.42E-14 & $3.27 \mathrm{E}-14$ & $3.08 \mathrm{E}-14$ & $2.85 \mathrm{E}-14$ & $2.59 \mathrm{E}-14$ & $2.30 \mathrm{E}-14$ & $2.05 \mathrm{E}-14$ \\
\hline ND144 & 2.99E-02 & 3.19E-02 & $3.48 \mathrm{E}-02$ & $3.76 \mathrm{E}-02$ & 3.99E-02 & 4.18E-02 & 4.31E-02 & $4.39 \mathrm{E}-02$ & 4.41E-02 & 4.38E-02 & 4.29E-02 & 4.15E-02 & 3.95E-02 & $3.71 \mathrm{E}-02$ & $3.41 \mathrm{E}-02$ & 3.08E-02 & 2.72E-02 & 2.41E-02 \\
\hline ND145 & $2.15 \mathrm{E}-02$ & 2.29E-02 & $2.49 \mathrm{E}-02$ & $2.68 \mathrm{E}-02$ & $2.85 \mathrm{E}-02$ & $2.97 \mathrm{E}-02$ & $3.06 \mathrm{E}-02$ & $3.12 \mathrm{E}-02$ & 3.13E-02 & 3.11E-02 & $3.05 E-02$ & $2.95 \mathrm{E}-02$ & $2.82 \mathrm{E}-02$ & $2.65 \mathrm{E}-02$ & $2.44 \mathrm{E}-02$ & $2.21 \mathrm{E}-02$ & $1.96 \mathrm{E}-02$ & $1.74 \mathrm{E}-02$ \\
\hline ND146 & $1.73 \mathrm{E}-02$ & 1.85E-02 & 2.03E-02 & 2.19E-02 & $2.33 \mathrm{E}-02$ & 2.44E-02 & $2.52 \mathrm{E}-02$ & $2.56 \mathrm{E}-02$ & $2.58 \mathrm{E}-02$ & $2.56 \mathrm{E}-02$ & 2.50E-02 & $2.42 \mathrm{E}-02$ & $2.31 \mathrm{E}-02$ & 2.16E-02 & $1.99 \mathrm{E}-02$ & $1.79 \mathrm{E}-02$ & $1.58 \mathrm{E}-02$ & 1.39E-02 \\
\hline PM146 & $8.38 \mathrm{E}-08$ & $1.02 E-07$ & 1.24E- 07 & 1.46E-07 & 1.66E-07 & 1.82E-07 & 1.94E-07 & $2.01 \mathrm{E}-07$ & 2.03E-07 & $2.00 \mathrm{E}-07$ & $1.92 \mathrm{E}-07$ & $1.80 \mathrm{E}-07$ & $1.63 \mathrm{E}-07$ & 1.43E-07 & $1.21 \mathrm{E}-07$ & $9.75 \mathrm{E}-08$ & $7.48 \mathrm{E}-08$ & $5.51 \mathrm{E}-08$ \\
\hline SM146 & $8.13 \mathrm{E}-07$ & $9.93 \mathrm{E}-07$ & 1.21E-06 & 1.42E-06 & 1.62E-06 & 1.78E-06 & 1.89E-06 & $1.96 \mathrm{E}-06$ & $1.98 \mathrm{E}-06$ & 1.95E-06 & 1.87E-06 & 1.75E-06 & 1.59E-06 & 1.39E- 06 & 1.17E-06 & $9.46 \mathrm{E}-07$ & $7.24 \mathrm{E}-07$ & $5.32 \mathrm{E}-07$ \\
\hline ND147 & $0.00 \mathrm{E}+00$ & $0.00 \mathrm{E}+00$ & $0.00 \mathrm{E}+00$ & $0.00 \mathrm{E}+00$ & $0.00 \mathrm{E}+00$ & $0.00 E+00$ & $0.00 \mathrm{E}+00$ & $0.00 \mathrm{E}+00$ & $0.00 \mathrm{E}+00$ & $0.00 E+00$ & $0.00 \mathrm{E}+00$ & $0.00 E+00$ & $0.00 \mathrm{E}+00$ & $0.00 \mathrm{E}+00$ & $0.00 E+00$ & $0.00 \mathrm{E}+00$ & $0.00 E+00$ & $0.00 \mathrm{E}+00$ \\
\hline PM147 & $6.26 \mathrm{E}-05$ & $6.56 \mathrm{E}-05$ & 7.04E-05 & $7.48 \mathrm{E}-05$ & $7.85 \mathrm{E}-05$ & 8.13E-05 & $8.32 E-05$ & 8.43E-05 & 8.47E-05 & $8.42 E-05$ & $8.29 \mathrm{E}-05$ & $8.08 \mathrm{E}-05$ & 7.79E-05 & $7.40 \mathrm{E}-05$ & $6.93 \mathrm{E}-05$ & $6.36 \mathrm{E}-05$ & $5.73 \mathrm{E}-05$ & 5.17E- 05 \\
\hline SM147 & 1.23E-02 & 1.29E-02 & 1.39E-02 & 1.47E-02 & 1.55E-02 & 1.60E-02 & 1.64E-02 & 1.67E-02 & 1.67E-02 & 1.66E-02 & 1.64E-02 & 1.59E-02 & 1.53E-02 & 1.46E-02 & 1.36E-02 & $1.25 \mathrm{E}-02$ & 1.12E-02 & $1.01 \mathrm{E}-02$ \\
\hline ND148 & 1.01E-02 & $1.08 \mathrm{E}-02$ & 1.17E-02 & 1.27E-02 & $1.34 \mathrm{E}-02$ & 1.41E-02 & 1.45E-02 & 1.47E-02 & 1.48E-02 & 1.47E-02 & 1.44E-02 & 1.39E-02 & $1.33 \mathrm{E}-02$ & 1.25E-02 & 1.15E-02 & $1.04 \mathrm{E}-02$ & 9.19E-03 & $8.11 \mathrm{E}-03$ \\
\hline PM148 & $0.00 \mathrm{E}+00$ & $0.00 \mathrm{E}+00$ & $0.00 \mathrm{E}+00$ & $0.00 \mathrm{E}+00$ & $0.00 E+00$ & $0.00 \mathrm{E}+00$ & $0.00 \mathrm{E}+00$ & $0.00 E+00$ & $0.00 E+00$ & $0.00 \mathrm{E}+00$ & $0.00 \mathrm{E}+00$ & $0.00 \mathrm{E}+00$ & $0.00 E+00$ & $0.00 \mathrm{E}+00$ & $0.00 E+00$ & $0.00 E+00$ & $0.00 E+00$ & $0.00 \mathrm{E}+00$ \\
\hline PM148M & $0.00 \mathrm{E}+00$ & $0.00 \mathrm{E}+00$ & $0.00 \mathrm{E}+00$ & $0.00 \mathrm{E}+00$ & $0.00 \mathrm{E}+00$ & $0.00 \mathrm{E}+00$ & $0.00 \mathrm{E}+00$ & $0.00 \mathrm{E}+00$ & $0.00 \mathrm{E}+00$ & $0.00 \mathrm{E}+00$ & $0.00 \mathrm{E}+00$ & $0.00 \mathrm{E}+00$ & $0.00 E+00$ & $0.00 \mathrm{E}+00$ & $0.00 \mathrm{E}+00$ & $0.00 E+00$ & $0.00 \mathrm{E}+00$ & $0.00 \mathrm{E}+00$ \\
\hline SM148 & $1.54 \mathrm{E}-03$ & $1.88 \mathrm{E}-03$ & $2.28 \mathrm{E}-03$ & $2.67 \mathrm{E}-03$ & $3.02 \mathrm{E}-03$ & $3.31 \mathrm{E}-03$ & $3.52 \mathrm{E}-03$ & $3.65 \mathrm{E}-03$ & $3.68 \mathrm{E}-03$ & 3.63E-03 & $3.49 \mathrm{E}-03$ & $3.26 \mathrm{E}-03$ & $2.96 \mathrm{E}-03$ & $2.61 \mathrm{E}-03$ & $2.21 \mathrm{E}-03$ & $1.79 \mathrm{E}-03$ & $1.38 \mathrm{E}-03$ & $1.02 \mathrm{E}-03$ \\
\hline SM149 & $6.40 \mathrm{E}-03$ & $6.83 \mathrm{E}-03$ & 7.42E-03 & $7.98 \mathrm{E}-03$ & 8.45E-03 & 8.82E-03 & $9.08 \mathrm{E}-03$ & $9.23 \mathrm{E}-03$ & $9.28 \mathrm{E}-03$ & $9.21 \mathrm{E}-03$ & $9.04 \mathrm{E}-03$ & $8.76 \mathrm{E}-03$ & $8.37 \mathrm{E}-03$ & 7.88E-03 & 7.28E-03 & $6.60 \mathrm{E}-03$ & $5.86 \mathrm{E}-03$ & $5.19 \mathrm{E}-03$ \\
\hline ND150 & $4.30 \mathrm{E}-03$ & 4.63E-03 & $5.07 \mathrm{E}-03$ & $5.48 \mathrm{E}-03$ & $5.82 \mathrm{E}-03$ & $6.09 \mathrm{E}-03$ & $6.29 \mathrm{E}-03$ & $6.40 \mathrm{E}-03$ & $6.43 \mathrm{E}-03$ & $6.38 \mathrm{E}-03$ & $6.25 \mathrm{E}-03$ & $6.05 \mathrm{E}-03$ & $5.76 \mathrm{E}-03$ & $5.40 \mathrm{E}-03$ & $4.97 \mathrm{E}-03$ & $4.48 \mathrm{E}-03$ & $3.95 \mathrm{E}-03$ & $3.46 \mathrm{E}-03$ \\
\hline SM150 & 4.63E-04 & $5.71 \mathrm{E}-04$ & $7.00 \mathrm{E}-04$ & $8.28 \mathrm{E}-04$ & $9.44 \mathrm{E}-04$ & $1.04 \mathrm{E}-03$ & 1.11E-03 & 1.15E-03 & 1.17E-03 & 1.15E-03 & 1.10E-03 & 1.03E-03 & $9.26 \mathrm{E}-04$ & $8.09 E-04$ & $6.79 \mathrm{E}-04$ & $5.45 \mathrm{E}-04$ & 4.14E-04 & $3.02 E-04$ \\
\hline SM151 & $2.26 \mathrm{E}-03$ & $2.41 \mathrm{E}-03$ & 2.61E-03 & $2.80 \mathrm{E}-03$ & $2.96 \mathrm{E}-03$ & 3.09E-03 & $3.17 E-03$ & $3.22 \mathrm{E}-03$ & $3.24 \mathrm{E}-03$ & 3.22E-03 & $3.16 \mathrm{E}-03$ & $3.06 \mathrm{E}-03$ & $2.94 \mathrm{E}-03$ & $2.77 \mathrm{E}-03$ & $2.57 \mathrm{E}-03$ & $2.33 \mathrm{E}-03$ & $2.07 \mathrm{E}-03$ & $1.84 \mathrm{E}-03$ \\
\hline
\end{tabular}

Position=Segment location (midpoint of 2 -in. segment) from bottom of fuel (BOF); 2 in. of fuel $\sim 14.2 \mathrm{~g}$ 
Table A-1j. Composition (grams) in 2-inch fuel segment: ORIGEN calculation results for Pin195011, decayed to 3/11/2011.

\begin{tabular}{|c|c|c|c|c|c|c|c|c|c|c|c|c|c|c|c|c|c|c|}
\hline Position: & 1 & 3 & 5 & 7 & 9 & 11 & 13 & 15 & 17 & 19 & 21 & 23 & 25 & 27 & 29 & 31 & 33 & 35 \\
\hline EU151 & $3.74 \mathrm{E}-04$ & $3.99 \mathrm{E}-04$ & $4.32 \mathrm{E}-04$ & $4.63 \mathrm{E}-04$ & $4.89 \mathrm{E}-04$ & $5.10 \mathrm{E}-04$ & $5.24 \mathrm{E}-04$ & $5.32 \mathrm{E}-04$ & $5.34 \mathrm{E}-04$ & $5.31 \mathrm{E}-04$ & $5.21 \mathrm{E}-04$ & $5.06 \mathrm{E}-04$ & $4.85 \mathrm{E}-04$ & 4.57E-04 & 4.24E-04 & $3.86 \mathrm{E}-04$ & $3.44 \mathrm{E}-04$ & $3.05 \mathrm{E}-04$ \\
\hline SM152 & $2.20 \mathrm{E}-03$ & $2.42 \mathrm{E}-03$ & $2.69 \mathrm{E}-03$ & $2.95 \mathrm{E}-03$ & 3.18E-03 & $3.36 \mathrm{E}-03$ & 3.49E-03 & $3.56 \mathrm{E}-03$ & $3.58 \mathrm{E}-03$ & $3.55 \mathrm{E}-03$ & $3.46 \mathrm{E}-03$ & 3.33E-03 & $3.14 \mathrm{E}-03$ & $2.91 \mathrm{E}-03$ & $2.63 \mathrm{E}-03$ & $2.33 \mathrm{E}-03$ & $2.01 \mathrm{E}-03$ & $1.73 \mathrm{E}-03$ \\
\hline EU152 & $8.79 \mathrm{E}-07$ & $1.05 \mathrm{E}-06$ & $1.26 \mathrm{E}-06$ & $1.45 \mathrm{E}-06$ & $1.61 \mathrm{E}-06$ & $1.75 \mathrm{E}-06$ & 1.84E-06 & $1.90 \mathrm{E}-06$ & $1.92 \mathrm{E}-06$ & 1.89E-06 & 1.83E-06 & $1.72 \mathrm{E}-06$ & $1.58 \mathrm{E}-06$ & 1.41E-06 & $1.22 \mathrm{E}-06$ & $1.01 \mathrm{E}-06$ & $7.91 \mathrm{E}-07$ & $5.94 \mathrm{E}-07$ \\
\hline GD152 & $1.34 \mathrm{E}-06$ & $1.60 \mathrm{E}-06$ & $1.90 \mathrm{E}-06$ & $2.19 \mathrm{E}-06$ & $2.44 \mathrm{E}-06$ & $2.64 \mathrm{E}-06$ & $2.79 \mathrm{E}-06$ & 2.87E-06 & $2.89 \mathrm{E}-06$ & $2.86 \mathrm{E}-06$ & $2.76 \mathrm{E}-06$ & $2.61 \mathrm{E}-06$ & $2.40 \mathrm{E}-06$ & $2.14 \mathrm{E}-06$ & $1.85 \mathrm{E}-06$ & $1.53 \mathrm{E}-06$ & 1.20E-06 & $9.06 \mathrm{E}-07$ \\
\hline EU153 & $1.24 \mathrm{E}-03$ & $1.33 \mathrm{E}-03$ & $1.45 \mathrm{E}-03$ & $1.56 \mathrm{E}-03$ & $1.65 \mathrm{E}-03$ & $1.73 \mathrm{E}-03$ & $1.78 \mathrm{E}-03$ & $1.81 \mathrm{E}-03$ & $1.81 \mathrm{E}-03$ & $1.80 \mathrm{E}-03$ & 1.77E-03 & $1.71 \mathrm{E}-03$ & 1.64E-03 & $1.54 \mathrm{E}-03$ & $1.42 \mathrm{E}-03$ & 1.29E-03 & 1.14E-03 & $1.01 \mathrm{E}-03$ \\
\hline GD153 & $2.08 \mathrm{E}-16$ & $2.89 \mathrm{E}-16$ & $3.90 \mathrm{E}-16$ & $4.96 \mathrm{E}-16$ & $5.96 \mathrm{E}-16$ & $6.83 \mathrm{E}-16$ & $7.49 \mathrm{E}-16$ & $7.88 \mathrm{E}-16$ & $8.00 \mathrm{E}-16$ & $7.84 \mathrm{E}-16$ & 7.39E-16 & $6.70 \mathrm{E}-16$ & $5.83 \mathrm{E}-16$ & 4.82E-16 & $3.77 \mathrm{E}-16$ & $2.75 \mathrm{E}-16$ & $1.85 \mathrm{E}-16$ & 1.13E-16 \\
\hline SM154 & $6.41 \mathrm{E}-04$ & $6.97 \mathrm{E}-04$ & $7.69 \mathrm{E}-04$ & $8.36 \mathrm{E}-04$ & $8.93 \mathrm{E}-04$ & $9.38 \mathrm{E}-04$ & $9.70 \mathrm{E}-04$ & 9.89E-04 & $9.94 \mathrm{E}-04$ & $9.86 \mathrm{E}-04$ & $9.65 \mathrm{E}-04$ & $9.30 \mathrm{E}-04$ & $8.83 \mathrm{E}-04$ & $8.24 \mathrm{E}-04$ & 7.54E-04 & $6.75 \mathrm{E}-04$ & $5.90 \mathrm{E}-04$ & $5.11 \mathrm{E}-04$ \\
\hline EU154 & 2.67E-05 & $3.27 \mathrm{E}-05$ & $3.97 \mathrm{E}-05$ & $4.66 \mathrm{E}-05$ & $5.27 \mathrm{E}-05$ & $5.78 \mathrm{E}-05$ & $6.15 \mathrm{E}-05$ & $6.37 \mathrm{E}-05$ & $6.43 \mathrm{E}-05$ & $6.34 \mathrm{E}-05$ & $6.09 \mathrm{E}-05$ & $5.70 \mathrm{E}-05$ & $5.18 \mathrm{E}-05$ & 4.56E-05 & $3.86 \mathrm{E}-05$ & 3.13E-05 & $2.40 \mathrm{E}-05$ & $1.76 \mathrm{E}-05$ \\
\hline GD154 & $1.03 \mathrm{E}-04$ & $1.27 \mathrm{E}-04$ & 1.54E-04 & $1.81 \mathrm{E}-04$ & $2.05 \mathrm{E}-04$ & $2.24 \mathrm{E}-04$ & 2.39E-04 & $2.47 \mathrm{E}-04$ & $2.50 \mathrm{E}-04$ & $2.46 \mathrm{E}-04$ & 2.36E-04 & 2.21E-04 & $2.01 \mathrm{E}-04$ & $1.77 \mathrm{E}-04$ & 1.50E-04 & $1.21 \mathrm{E}-04$ & $9.30 \mathrm{E}-05$ & $6.81 \mathrm{E}-05$ \\
\hline EU155 & $2.36 \mathrm{E}-05$ & $2.56 \mathrm{E}-05$ & $2.81 \mathrm{E}-05$ & $3.06 \mathrm{E}-05$ & 3.27E-05 & 3.43E-05 & 3.55E-05 & $3.62 \mathrm{E}-05$ & $3.64 \mathrm{E}-05$ & $3.61 \mathrm{E}-05$ & 3.53E-05 & 3.40E-05 & 3.23E-05 & $3.02 E-05$ & $2.76 \mathrm{E}-05$ & $2.48 \mathrm{E}-05$ & 2.17E-05 & 1.89E-05 \\
\hline GD155 & 3.62E-04 & $3.92 \mathrm{E}-04$ & 4.30E-04 & 4.67E-04 & $4.98 \mathrm{E}-04$ & $5.23 \mathrm{E}-04$ & $5.41 \mathrm{E}-04$ & $5.52 \mathrm{E}-04$ & $5.55 \mathrm{E}-04$ & $5.50 \mathrm{E}-04$ & $5.38 \mathrm{E}-04$ & 5.19E-04 & 4.93E- 04 & $4.60 \mathrm{E}-04$ & 4.22E-04 & $3.79 \mathrm{E}-04$ & $3.32 \mathrm{E}-04$ & $2.90 \mathrm{E}-04$ \\
\hline EU156 & $0.00 E+00$ & $0.00 E+00$ & $0.00 \mathrm{E}+00$ & $0.00 E+00$ & $0.00 E+00$ & $0.00 E+00$ & $0.00 \mathrm{E}+00$ & $0.00 \mathrm{E}+00$ & $0.00 E+00$ & $0.00 \mathrm{E}+00$ & $0.00 \mathrm{E}+00$ & $0.00 \mathrm{E}+00$ & $0.00 \mathrm{E}+00$ & $0.00 \mathrm{E}+00$ & $0.00 \mathrm{E}+00$ & $0.00 E+00$ & $0.00 E+00$ & $0.00 \mathrm{E}+00$ \\
\hline GD156 & $2.57 \mathrm{E}-04$ & $2.89 \mathrm{E}-04$ & 3.27E-04 & 3.63E-04 & $3.95 \mathrm{E}-04$ & 4.21E-04 & $4.40 \mathrm{E}-04$ & $4.51 \mathrm{E}-04$ & 4.54E-04 & 4.49E-04 & 4.37E-04 & 4.17E-04 & $3.90 \mathrm{E}-04$ & 3.57E- 04 & $3.20 \mathrm{E}-04$ & $2.79 \mathrm{E}-04$ & $2.36 \mathrm{E}-04$ & 1.97E-04 \\
\hline GD157 & $1.24 \mathrm{E}-04$ & $1.34 \mathrm{E}-04$ & 1.47E-04 & $1.60 \mathrm{E}-04$ & $1.70 \mathrm{E}-04$ & $1.78 \mathrm{E}-04$ & $1.84 \mathrm{E}-04$ & 1.87E-04 & $1.88 \mathrm{E}-04$ & 1.87E-04 & 1.83E-04 & $1.77 \mathrm{E}-04$ & 1.68E-04 & $1.57 \mathrm{E}-04$ & 1.45E-04 & $1.30 \mathrm{E}-04$ & 1.14E-04 & $9.91 \mathrm{E}-05$ \\
\hline GD158 & $9.37 \mathrm{E}-05$ & $1.06 \mathrm{E}-04$ & 1.20E-04 & $1.35 \mathrm{E}-04$ & $1.47 \mathrm{E}-04$ & $1.57 \mathrm{E}-04$ & 1.65E-04 & 1.69E-04 & $1.70 \mathrm{E}-04$ & 1.69E-04 & 1.63E-04 & $1.56 \mathrm{E}-04$ & $1.45 \mathrm{E}-04$ & 1.32E-04 & 1.18E-04 & $1.02 \mathrm{E}-04$ & $8.54 \mathrm{E}-05$ & $7.08 \mathrm{E}-05$ \\
\hline TB159 & $3.32 \mathrm{E}-05$ & $3.68 \mathrm{E}-05$ & 4.11E-05 & $4.53 \mathrm{E}-05$ & $4.89 \mathrm{E}-05$ & $5.17 \mathrm{E}-05$ & $5.38 \mathrm{E}-05$ & $5.50 \mathrm{E}-05$ & $5.53 \mathrm{E}-05$ & $5.48 \mathrm{E}-05$ & $5.34 \mathrm{E}-05$ & $5.12 \mathrm{E}-05$ & $4.82 \mathrm{E}-05$ & 4.45E-05 & 4.02E-05 & $3.55 \mathrm{E}-05$ & $3.05 E-05$ & 2.58E-05 \\
\hline GD160 & $1.77 \mathrm{E}-05$ & $1.97 \mathrm{E}-05$ & $2.21 \mathrm{E}-05$ & $2.45 \mathrm{E}-05$ & $2.65 \mathrm{E}-05$ & $2.81 \mathrm{E}-05$ & $2.93 \mathrm{E}-05$ & $3.00 \mathrm{E}-05$ & 3.02E-05 & $2.99 \mathrm{E}-05$ & $2.91 \mathrm{E}-05$ & $2.78 \mathrm{E}-05$ & $2.61 \mathrm{E}-05$ & $2.40 \mathrm{E}-05$ & $2.16 \mathrm{E}-05$ & $1.89 \mathrm{E}-05$ & 1.61E-05 & 1.36E-05 \\
\hline TB160 & $2.84 \mathrm{E}-34$ & $3.64 \mathrm{E}-34$ & $4.58 \mathrm{E}-34$ & $5.53 \mathrm{E}-34$ & $6.41 \mathrm{E}-34$ & $7.15 \mathrm{E}-34$ & $7.70 \mathrm{E}-34$ & $8.04 \mathrm{E}-34$ & $8.14 \mathrm{E}-34$ & $8.00 \mathrm{E}-34$ & $7.63 \mathrm{E}-34$ & $7.05 E-34$ & $6.30 \mathrm{E}-34$ & $5.42 \mathrm{E}-34$ & 4.47E-34 & $3.51 \mathrm{E}-34$ & $2.59 \mathrm{E}-34$ & $1.80 \mathrm{E}-34$ \\
\hline DY160 & $1.96 \mathrm{E}-06$ & $2.49 \mathrm{E}-06$ & 3.10E-06 & $3.72 \mathrm{E}-06$ & $4.29 \mathrm{E}-06$ & $4.76 \mathrm{E}-06$ & $5.11 \mathrm{E}-06$ & $5.33 \mathrm{E}-06$ & $5.39 \mathrm{E}-06$ & $5.30 \mathrm{E}-06$ & $5.06 \mathrm{E}-06$ & 4.68E-06 & 4.20E-06 & $3.63 \mathrm{E}-06$ & $3.01 \mathrm{E}-06$ & $2.38 \mathrm{E}-06$ & $1.77 \mathrm{E}-06$ & 1.24E-06 \\
\hline DY161 & $7.71 \mathrm{E}-06$ & $8.62 \mathrm{E}-06$ & $9.69 \mathrm{E}-06$ & $1.07 \mathrm{E}-05$ & 1.16E-05 & $1.23 \mathrm{E}-05$ & 1.28E-05 & 1.30E-05 & $1.31 \mathrm{E}-05$ & $1.30 \mathrm{E}-05$ & 1.27E-05 & 1.21E-05 & 1.14E-05 & $1.05 E-05$ & $9.48 \mathrm{E}-06$ & $8.34 \mathrm{E}-06$ & $7.12 \mathrm{E}-06$ & $5.96 \mathrm{E}-06$ \\
\hline DY162 & $5.44 \mathrm{E}-06$ & $6.22 \mathrm{E}-06$ & $7.10 \mathrm{E}-06$ & $7.93 \mathrm{E}-06$ & $8.66 \mathrm{E}-06$ & $9.24 \mathrm{E}-06$ & $9.67 \mathrm{E}-06$ & $9.92 \mathrm{E}-06$ & $9.99 \mathrm{E}-06$ & $9.88 \mathrm{E}-06$ & $9.59 \mathrm{E}-06$ & $9.14 \mathrm{E}-06$ & $8.54 \mathrm{E}-06$ & $7.80 \mathrm{E}-06$ & $6.94 \mathrm{E}-06$ & $6.02 \mathrm{E}-06$ & $5.05 \mathrm{E}-06$ & 4.13E- 06 \\
\hline
\end{tabular}

lxxvi 


\begin{tabular}{|c|c|c|c|c|c|c|c|c|c|c|c|c|c|c|c|c|c|c|}
\hline DY163 & & & & & & & & & & & & & & & & & & \\
\hline & $2.29 E-06$ & 2.64E-06 & $3.02 \mathrm{E}-00$ & $3.36 \mathrm{E}-00$ & $3.67 \mathrm{E}-06$ & $3.92 E-06$ & $4.09 E-06$ & $\begin{array}{l}4.20 \mathrm{E}-06 \\
\end{array}$ & $4.23 \mathrm{E}-06$ & $4.18 \mathrm{E}-06$ & $4.06 \mathrm{E}-06$ & $3.87 \mathrm{E}-06$ & $3.62 \mathrm{E}-06$ & $3.31 E-06$ & $2.95 \mathrm{E}-06$ & $2.57 \mathrm{E}-06$ & $2.15 \mathrm{E}-06$ & $1.74 \mathrm{E}-06$ \\
\hline DY164 & $1.30 \mathrm{E}-06$ & $1.50 \mathrm{E}-06$ & $1.71 \mathrm{E}-06$ & $1.91 \mathrm{E}-06$ & $2.08 \mathrm{E}-06$ & $2.22 E-06$ & 2.32E-06 & $2.38 \mathrm{E}-06$ & $2.39 \mathrm{E}-06$ & $2.37 \mathrm{E}-06$ & $2.30 \mathrm{E}-06$ & $2.19 \mathrm{E}-06$ & $2.05 \mathrm{E}-06$ & $1.88 \mathrm{E}-06$ & $1.68 \mathrm{E}-06$ & $1.46 \mathrm{E}-06$ & $1.22 \mathrm{E}-06$ & $9.87 \mathrm{E}-07$ \\
\hline HO165 & $6.58 \mathrm{E}-07$ & $7.55 \mathrm{E}-07$ & $8.58 \mathrm{E}-07$ & $9.52 \mathrm{E}-07$ & $1.03 \mathrm{E}-06$ & $1.10 \mathrm{E}-06$ & 1.14E- -06 & $1.17 \mathrm{E}-06$ & $1.18 \mathrm{E}-06$ & $1.17 \mathrm{E}-06$ & $1.14 \mathrm{E}-06$ & $1.09 \mathrm{E}-06$ & $1.02 E-06$ & $9.37 \mathrm{E}-07$ & $8.41 \mathrm{E}-07$ & 7.35E-07 & $6.20 \mathrm{E}-07$ & $5.05 \mathrm{E}-07$ \\
\hline
\end{tabular}

Position=Segment location (midpoint of 2-in. segment) from bottom of fuel (BOF); 2 in. of fuel $~ 14.2 \mathrm{~g}$. 
Table A-1k. Composition (grams) in 2-inch fuel segment: ORIGEN calculation results for Pin 195011, decayed to 3/11/2011.

\begin{tabular}{|c|c|c|c|c|c|c|c|c|c|c|c|c|c|c|c|c|c|c|}
\hline Position: & 1 & 3 & 5 & 7 & 9 & 11 & 13 & 15 & 17 & 19 & 21 & 23 & 25 & 27 & 29 & 31 & 33 & 35 \\
\hline ER166 & $4.14 \mathrm{E}-07$ & $4.83 \mathrm{E}-07$ & $5.58 \mathrm{E}-07$ & $6.27 \mathrm{E}-07$ & $6.88 \mathrm{E}-07$ & $7.37 \mathrm{E}-07$ & $7.73 \mathrm{E}-07$ & $7.94 \mathrm{E}-07$ & $8.00 \mathrm{E}-07$ & $7.91 \mathrm{E}-07$ & $7.67 \mathrm{E}-07$ & $7.29 \mathrm{E}-07$ & $6.78 \mathrm{E}-07$ & $6.16 \mathrm{E}-07$ & $5.46 \mathrm{E}-07$ & 4.69E- 07 & $3.89 \mathrm{E}-07$ & $3.10 \mathrm{E}-07$ \\
\hline ER167 & $2.09 \mathrm{E}-07$ & $2.40 \mathrm{E}-07$ & $2.72 \mathrm{E}-07$ & $3.01 \mathrm{E}-07$ & $3.26 \mathrm{E}-07$ & 3.46E-07 & $3.60 \mathrm{E}-07$ & 3.68E-07 & $3.71 \mathrm{E}-07$ & $3.67 \mathrm{E}-07$ & $3.57 \mathrm{E}-07$ & 3.42E-07 & $3.22 \mathrm{E}-07$ & $2.97 \mathrm{E}-07$ & $2.67 \mathrm{E}-07$ & $2.34 \mathrm{E}-07$ & $1.99 \mathrm{E}-07$ & $1.62 \mathrm{E}-07$ \\
\hline ER168 & $1.32 \mathrm{E}-08$ & $1.75 \mathrm{E}-08$ & $2.23 \mathrm{E}-08$ & $2.70 \mathrm{E}-08$ & 3.13E-08 & $3.50 \mathrm{E}-08$ & 3.77E- 08 & $3.93 \mathrm{E}-08$ & $3.98 \mathrm{E}-08$ & $3.91 \mathrm{E}-08$ & $3.72 \mathrm{E}-08$ & $3.44 \mathrm{E}-08$ & $3.07 \mathrm{E}-08$ & $2.64 \mathrm{E}-08$ & $2.17 \mathrm{E}-08$ & 1.69E-08 & 1.24E-08 & $8.31 \mathrm{E}-09$ \\
\hline $\begin{array}{l}\text { SUM FPs } \\
\text { isotope }\end{array}$ & $9.50 \mathrm{E}-01$ & $1.01 \mathrm{E}+00$ & $1.11 \mathrm{E}+00$ & 1.19E+00 & $1.27 \mathrm{E}+00$ & $1.33 E+00$ & $1.37 E+00$ & $1.39 \mathrm{E}+00$ & $1.40 \mathrm{E}+00$ & $1.39 \mathrm{E}+00$ & $1.36 \mathrm{E}+00$ & $1.32 E+00$ & $1.26 \mathrm{E}+00$ & $1.18 \mathrm{E}+00$ & $1.08 \mathrm{E}+00$ & $9.78 \mathrm{E}-01$ & $8.65 \mathrm{E}-01$ & $7.65 \mathrm{E}-01$ \\
\hline $\mathrm{H}$ & $7.93 \mathrm{E}-07$ & $8.48 \mathrm{E}-07$ & $9.25 \mathrm{E}-07$ & $9.98 \mathrm{E}-07$ & 1.06E- 06 & $1.11 \mathrm{E}-06$ & 1. $14 \mathrm{E}-06$ & 1.16E-06 & 1.17E-06 & 1.16E-06 & 1.14E-06 & 1.10E-06 & $1.05 \mathrm{E}-06$ & $9.85 \mathrm{E}-07$ & $9.07 \mathrm{E}-07$ & 8.19E-07 & $7.24 \mathrm{E}-07$ & $6.40 \mathrm{E}-07$ \\
\hline 니 & $1.21 \mathrm{E}-08$ & $1.29 \mathrm{E}-08$ & 1.40E-08 & 1.50E-08 & $1.59 \mathrm{E}-08$ & 1.66E-08 & $1.71 \mathrm{E}-08$ & $1.74 \mathrm{E}-08$ & $1.75 \mathrm{E}-08$ & 1.74E-08 & $1.70 \mathrm{E}-08$ & 1.65E-08 & $1.58 \mathrm{E}-08$ & 1.48E-08 & $1.37 \mathrm{E}-08$ & $1.24 \mathrm{E}-08$ & 1.10E-08 & $9.81 \mathrm{E}-09$ \\
\hline GE & 5.03E-05 & $5.37 \mathrm{E}-05$ & $5.85 \mathrm{E}-05$ & $6.31 \mathrm{E}-05$ & $6.69 \mathrm{E}-05$ & $6.99 \mathrm{E}-05$ & $7.21 \mathrm{E}-05$ & 7.33E-05 & $7.37 \mathrm{E}-05$ & 7.31E-05 & 7.17E-05 & $6.94 \mathrm{E}-05$ & 6.63E-05 & $6.22 \mathrm{E}-05$ & $5.74 \mathrm{E}-05$ & 5.19E-05 & 4.59E-05 & $4.06 \mathrm{E}-05$ \\
\hline AS & $1.51 \mathrm{E}-05$ & $1.61 \mathrm{E}-05$ & $1.75 \mathrm{E}-05$ & $1.88 \mathrm{E}-05$ & $2.00 \mathrm{E}-05$ & $2.08 \mathrm{E}-05$ & 2.15E-05 & $2.18 \mathrm{E}-05$ & 2.19E-05 & $2.18 \mathrm{E}-05$ & 2.14E-05 & 2.07E-05 & $1.98 \mathrm{E}-05$ & $1.86 \mathrm{E}-05$ & $1.72 \mathrm{E}-05$ & 1.56E-05 & $1.38 \mathrm{E}-05$ & $1.22 \mathrm{E}-05$ \\
\hline SE & 1.96E-03 & 2.09E-03 & $2.27 \mathrm{E}-03$ & $2.45 \mathrm{E}-03$ & 2.60E-03 & $2.71 \mathrm{E}-03$ & $2.80 \mathrm{E}-03$ & $2.85 \mathrm{E}-03$ & $2.86 \mathrm{E}-03$ & $2.84 \mathrm{E}-03$ & $2.78 \mathrm{E}-03$ & $2.69 \mathrm{E}-03$ & $2.57 \mathrm{E}-03$ & $2.42 \mathrm{E}-03$ & $2.23 \mathrm{E}-03$ & $2.02 \mathrm{E}-03$ & 1.79E-03 & $1.58 \mathrm{E}-03$ \\
\hline $\mathrm{BR}$ & $7.36 \mathrm{E}-04$ & 7.82E-04 & $8.49 \mathrm{E}-04$ & $9.12 \mathrm{E}-04$ & $9.65 \mathrm{E}-04$ & $1.01 \mathrm{E}-03$ & $1.04 \mathrm{E}-03$ & $1.05 \mathrm{E}-03$ & 1.06E-03 & $1.05 \mathrm{E}-03$ & $1.03 \mathrm{E}-03$ & $9.99 \mathrm{E}-04$ & $9.56 \mathrm{E}-04$ & $9.00 \mathrm{E}-04$ & $8.32 \mathrm{E}-04$ & $7.55 \mathrm{E}-04$ & $6.71 \mathrm{E}-04$ & $5.97 \mathrm{E}-04$ \\
\hline $\mathrm{KR}$ & 1.23E-02 & $1.30 \mathrm{E}-02$ & 1.42E-02 & $1.53 \mathrm{E}-02$ & 1.62E-02 & 1.69E-02 & 1.74E-02 & $1.77 \mathrm{E}-02$ & $1.78 \mathrm{E}-02$ & 1.77E-02 & $1.74 \mathrm{E}-02$ & 1.68E-02 & 1.60E-02 & $1.51 \mathrm{E}-02$ & $1.39 \mathrm{E}-02$ & 1.26E-02 & $1.11 \mathrm{E}-02$ & $9.89 \mathrm{E}-03$ \\
\hline $\mathrm{RB}$ & $1.24 \mathrm{E}-02$ & $1.32 \mathrm{E}-02$ & $1.43 \mathrm{E}-02$ & $1.54 \mathrm{E}-02$ & $1.63 \mathrm{E}-02$ & $1.70 \mathrm{E}-02$ & 1.76E-02 & $1.79 \mathrm{E}-02$ & $1.79 \mathrm{E}-02$ & $1.78 \mathrm{E}-02$ & $1.75 \mathrm{E}-02$ & 1.69E-02 & 1.62E-02 & $1.52 \mathrm{E}-02$ & $1.40 \mathrm{E}-02$ & 1.27E-02 & 1.13E-02 & $1.00 \mathrm{E}-02$ \\
\hline$S R$ & $2.41 \mathrm{E}-02$ & $2.56 \mathrm{E}-02$ & $2.78 \mathrm{E}-02$ & $2.99 \mathrm{E}-02$ & 3.17E-02 & $3.31 \mathrm{E}-02$ & 3.42E-02 & 3.47E-02 & 3.49E-02 & $3.47 \mathrm{E}-02$ & $3.40 \mathrm{E}-02$ & $3.29 \mathrm{E}-02$ & $3.14 \mathrm{E}-02$ & $2.95 \mathrm{E}-02$ & $2.72 \mathrm{E}-02$ & $2.46 \mathrm{E}-02$ & $2.19 \mathrm{E}-02$ & $1.95 \mathrm{E}-02$ \\
\hline Y & $1.56 \mathrm{E}-02$ & 1.66E-02 & $1.80 \mathrm{E}-02$ & $1.94 \mathrm{E}-02$ & $2.06 \mathrm{E}-02$ & $2.15 \mathrm{E}-02$ & $2.21 \mathrm{E}-02$ & $2.25 \mathrm{E}-02$ & $2.26 \mathrm{E}-02$ & $2.25 \mathrm{E}-02$ & $2.20 \mathrm{E}-02$ & $2.13 \mathrm{E}-02$ & $2.04 \mathrm{E}-02$ & $1.91 \mathrm{E}-02$ & $1.77 \mathrm{E}-02$ & $1.60 \mathrm{E}-02$ & 1.42E-02 & $1.26 \mathrm{E}-02$ \\
\hline$Z R$ & 1.17E-01 & $1.24 \mathrm{E}-01$ & $1.35 \mathrm{E}-01$ & 1.45E-01 & $1.54 \mathrm{E}-01$ & $1.61 \mathrm{E}-01$ & 1.66E-01 & 1.69E-01 & $1.70 \mathrm{E}-01$ & 1.69E-01 & $1.65 \mathrm{E}-01$ & 1.60E-01 & 1.53E-01 & 1.43E-01 & $1.32 \mathrm{E}-01$ & $1.20 \mathrm{E}-01$ & $1.06 \mathrm{E}-01$ & $9.41 \mathrm{E}-02$ \\
\hline NB & 2.14E-07 & 2.28E-07 & 2.48E-07 & $2.68 \mathrm{E}-07$ & 2.84E- 07 & $2.97 \mathrm{E}-07$ & 3.07E- 07 & $3.12 \mathrm{E}-07$ & 3.14E-07 & 3.11E-07 & $3.05 \mathrm{E}-07$ & 2.95E-07 & $2.81 \mathrm{E}-07$ & 2.64E-07 & $2.43 \mathrm{E}-07$ & 2.19E-07 & $1.94 \mathrm{E}-07$ & 1.72E- 07 \\
\hline Mo & $9.48 \mathrm{E}-02$ & $1.01 \mathrm{E}-01$ & 1.10E-01 & 1.19E- 01 & 1.26E-01 & $1.32 \mathrm{E}-01$ & 1.36E- 01 & 1.38E-01 & $1.39 \mathrm{E}-01$ & 1.38E-01 & $1.35 \mathrm{E}-01$ & $1.31 \mathrm{E}-01$ & 1.25E-01 & 1.17E-01 & $1.08 \mathrm{E}-01$ & $9.74 \mathrm{E}-02$ & 8.62E-02 & 7.63E- 02 \\
\hline TC & $2.24 \mathrm{E}-02$ & $2.38 \mathrm{E}-02$ & $2.59 \mathrm{E}-02$ & $2.79 \mathrm{E}-02$ & $2.96 \mathrm{E}-02$ & $3.09 \mathrm{E}-02$ & $3.18 \mathrm{E}-02$ & 3.24E-02 & $3.25 \mathrm{E}-02$ & $3.23 \mathrm{E}-02$ & $3.17 \mathrm{E}-02$ & $3.07 \mathrm{E}-02$ & $2.93 \mathrm{E}-02$ & $2.75 \mathrm{E}-02$ & $2.54 \mathrm{E}-02$ & $2.30 \mathrm{E}-02$ & $2.04 \mathrm{E}-02$ & $1.81 \mathrm{E}-02$ \\
\hline $\mathrm{RU}$ & $5.28 \mathrm{E}-02$ & $5.67 \mathrm{E}-02$ & $6.22 \mathrm{E}-02$ & $6.73 \mathrm{E}-02$ & 7.17E-02 & $7.52 \mathrm{E}-02$ & $7.76 \mathrm{E}-02$ & 7.91E-02 & $7.95 \mathrm{E}-02$ & $7.89 \mathrm{E}-02$ & $7.72 \mathrm{E}-02$ & 7.46E-02 & $7.09 \mathrm{E}-02$ & $6.64 \mathrm{E}-02$ & $6.09 \mathrm{E}-02$ & $5.47 \mathrm{E}-02$ & $4.81 \mathrm{E}-02$ & 4.22E-02 \\
\hline $\mathrm{RH}$ & 1.43E-02 & $1.54 \mathrm{E}-02$ & 1.68E-02 & $1.81 \mathrm{E}-02$ & 1.93E-02 & 2.02E-02 & 2.08E-02 & 2.12E- 02 & 2.13E-02 & 2.11E-02 & 2.07E-02 & 2.00E-02 & $1.91 \mathrm{E}-02$ & $1.79 \mathrm{E}-02$ & $1.64 \mathrm{E}-02$ & 1.48E-02 & $1.31 \mathrm{E}-02$ & 1.15E-02 \\
\hline $\mathrm{PD}$ & 1.53E-02 & 1.69E-02 & $1.89 \mathrm{E}-02$ & $2.08 \mathrm{E}-02$ & 2.24E-02 & $2.37 \mathrm{E}-02$ & $2.46 \mathrm{E}-02$ & $2.51 \mathrm{E}-02$ & $2.53 \mathrm{E}-02$ & $2.51 \mathrm{E}-02$ & $2.44 \mathrm{E}-02$ & $2.35 \mathrm{E}-02$ & $2.21 \mathrm{E}-02$ & $2.05 \mathrm{E}-02$ & $1.85 \mathrm{E}-02$ & 1.64E-02 & $1.41 \mathrm{E}-02$ & 1.20E-02 \\
\hline$A G$ & 1.11E-03 & 1.23E-03 & $1.37 \mathrm{E}-03$ & $1.50 \mathrm{E}-03$ & 1.62E-03 & $1.71 \mathrm{E}-03$ & $1.78 \mathrm{E}-03$ & 1.82E- 03 & 1.83E-03 & $1.81 \mathrm{E}-03$ & $1.77 \mathrm{E}-03$ & $1.70 \mathrm{E}-03$ & 1.60E-03 & 1.48E-03 & $1.34 \mathrm{E}-03$ & 1. $18 \mathrm{E}-03$ & 1.02E-03 & $8.66 \mathrm{E}-04$ \\
\hline$C D$ & $2.75 \mathrm{E}-03$ & $3.04 \mathrm{E}-03$ & $3.37 \mathrm{E}-03$ & 3.66E- 03 & $3.91 \mathrm{E}-03$ & 4.10E-03 & 4.24E- 03 & 4.32E- -03 & 4.34E-03 & $4.31 \mathrm{E}-03$ & $4.22 \mathrm{E}-03$ & 4.07E-03 & 3.87E-03 & 3.62E-03 & $3.31 \mathrm{E}-03$ & 2.97E-03 & $2.59 \mathrm{E}-03$ & 2.21E- -03 \\
\hline IN & $4.10 \mathrm{E}-04$ & 4.41E-04 & $4.74 \mathrm{E}-04$ & $5.01 \mathrm{E}-04$ & $5.23 \mathrm{E}-04$ & $5.39 \mathrm{E}-04$ & $5.49 \mathrm{E}-04$ & $5.55 \mathrm{E}-04$ & $5.57 \mathrm{E}-04$ & $5.54 \mathrm{E}-04$ & $5.47 \mathrm{E}-04$ & $5.36 \mathrm{E}-04$ & $5.19 \mathrm{E}-04$ & 4.97E-04 & 4.68E-04 & 4.33E-04 & $3.90 \mathrm{E}-04$ & $3.45 \mathrm{E}-04$ \\
\hline
\end{tabular}

Position=Segment location (midpoint of 2-in. segment) from bottom of fuel (BOF); 2 in. of fuel $\sim 14.2 \mathrm{~g}$

lxxviii 
Table A-11. Composition (grams) in 2-inch fuel segment: ORIGEN calculation results for Pin195011, decayed to 3/11/2011.

\begin{tabular}{|c|c|c|c|c|c|c|c|c|c|c|c|c|c|c|c|c|c|c|}
\hline Position: & 1 & 3 & 5 & 7 & 9 & 11 & 13 & 15 & 17 & 19 & 21 & 23 & 25 & 27 & 29 & 31 & 33 & 35 \\
\hline SN & $4.68 \mathrm{E}-03$ & $5.13 \mathrm{E}-03$ & $5.66 \mathrm{E}-03$ & $6.14 \mathrm{E}-03$ & $6.55 \mathrm{E}-03$ & $6.86 \mathrm{E}-03$ & $7.08 \mathrm{E}-03$ & $7.21 \mathrm{E}-03$ & $7.25 \mathrm{E}-03$ & $7.20 \mathrm{E}-03$ & $7.05 \mathrm{E}-03$ & $6.81 \mathrm{E}-03$ & $6.48 \mathrm{E}-03$ & $6.07 \mathrm{E}-03$ & $5.57 \mathrm{E}-03$ & $5.00 \mathrm{E}-03$ & 4.37E-03 & $3.76 \mathrm{E}-03$ \\
\hline SB & 1.12E-03 & $1.23 \mathrm{E}-03$ & 1.35E-03 & $1.46 \mathrm{E}-03$ & $1.55 \mathrm{E}-03$ & 1.62E-03 & 1.66E-03 & 1. $69 \mathrm{E}-03$ & $1.70 \mathrm{E}-03$ & $1.69 \mathrm{E}-03$ & 1.66E-03 & $1.60 \mathrm{E}-03$ & 1.53E-03 & $1.44 \mathrm{E}-03$ & $1.33 \mathrm{E}-03$ & $1.20 \mathrm{E}-03$ & 1.05E-03 & $9.09 \mathrm{E}-04$ \\
\hline $\mathrm{TE}$ & $1.55 \mathrm{E}-02$ & $1.66 \mathrm{E}-02$ & 1.82E-02 & 1.97E-02 & $2.09 \mathrm{E}-02$ & 2.19E-02 & $2.26 \mathrm{E}-02$ & $2.30 \mathrm{E}-02$ & $2.31 \mathrm{E}-02$ & $2.29 \mathrm{E}-02$ & $2.25 \mathrm{E}-02$ & $2.17 \mathrm{E}-02$ & $2.07 \mathrm{E}-02$ & $1.94 \mathrm{E}-02$ & $1.78 \mathrm{E}-02$ & 1.61E-02 & 1.42E-02 & 1.25E-02 \\
\hline 1 & $8.11 \mathrm{E}-03$ & $8.69 \mathrm{E}-03$ & $9.49 \mathrm{E}-03$ & 1.02E-02 & $1.09 \mathrm{E}-02$ & 1.14E-02 & $1.17 \mathrm{E}-02$ & 1.19E-02 & $1.20 \mathrm{E}-02$ & 1.19E-02 & 1.17E-02 & 1.13E-02 & $1.08 \mathrm{E}-02$ & $1.01 \mathrm{E}-02$ & $9.31 \mathrm{E}-03$ & $8.41 \mathrm{E}-03$ & 7.43E-03 & $6.54 \mathrm{E}-03$ \\
\hline $\mathrm{XE}$ & 1. $18 \mathrm{E}-01$ & 1.26E-01 & $1.38 \mathrm{E}-01$ & 1.49E-01 & 1.58E-01 & 1. $65 \mathrm{E}-01$ & $1.70 \mathrm{E}-01$ & $1.73 \mathrm{E}-01$ & $1.74 \mathrm{E}-01$ & $1.73 \mathrm{E}-01$ & 1.70E-01 & $1.64 \mathrm{E}-01$ & 1.56E-01 & 1.47E-01 & $1.35 \mathrm{E}-01$ & $1.22 \mathrm{E}-01$ & $1.08 \mathrm{E}-01$ & $9.50 \mathrm{E}-02$ \\
\hline CS & $8.92 E-02$ & $9.50 \mathrm{E}-02$ & $1.04 \mathrm{E}-01$ & 1.12E-01 & 1.19E-01 & 1.24E-01 & 1.28E-01 & 1.30E-01 & 1.31E-01 & $1.30 \mathrm{E}-01$ & 1.27E-01 & 1.23E-01 & 1.17E- 01 & 1. $10 \mathrm{E}-01$ & $1.02 \mathrm{E}-01$ & $9.16 \mathrm{E}-02$ & 8.11E-02 & 7.19E-02 \\
\hline $\mathrm{BA}$ & 4.93E-02 & $5.27 \mathrm{E}-02$ & $5.76 \mathrm{E}-02$ & $6.23 \mathrm{E}-02$ & $6.64 \mathrm{E}-02$ & $6.95 \mathrm{E}-02$ & 7.18E-02 & 7.31E-02 & 7.35E-02 & $7.29 \mathrm{E}-02$ & 7.14E-02 & $6.90 \mathrm{E}-02$ & $6.56 \mathrm{E}-02$ & $6.14 \mathrm{E}-02$ & $5.64 \mathrm{E}-02$ & $5.08 \mathrm{E}-02$ & 4.47E-02 & $3.95 \mathrm{E}-02$ \\
\hline LA & 3.49E-02 & $3.71 \mathrm{E}-02$ & 4.05E-02 & 4.37E-02 & 4.64E-02 & 4.85E-02 & $5.00 \mathrm{E}-02$ & 5.09E-02 & $5.11 \mathrm{E}-02$ & $5.08 \mathrm{E}-02$ & $4.98 \mathrm{E}-02$ & 4.81E-02 & 4.59E- 02 & 4.31E-02 & $3.97 \mathrm{E}-02$ & $3.58 \mathrm{E}-02$ & 3.17E-02 & $2.81 \mathrm{E}-02$ \\
\hline $\mathrm{CE}$ & $6.52 \mathrm{E}-02$ & $6.95 \mathrm{E}-02$ & $7.57 \mathrm{E}-02$ & $8.17 \mathrm{E}-02$ & $8.68 \mathrm{E}-02$ & $9.08 \mathrm{E}-02$ & $9.36 \mathrm{E}-02$ & $9.52 \mathrm{E}-02$ & $9.57 \mathrm{E}-02$ & $9.50 \mathrm{E}-02$ & $9.31 \mathrm{E}-02$ & $9.00 E-02$ & $8.59 \mathrm{E}-02$ & $8.06 \mathrm{E}-02$ & $7.42 \mathrm{E}-02$ & $6.70 \mathrm{E}-02$ & $5.93 \mathrm{E}-02$ & $5.25 \mathrm{E}-02$ \\
\hline PR & 3.31E-02 & $3.52 \mathrm{E}-02$ & 3.83E-02 & 4.13E-02 & $4.38 \mathrm{E}-02$ & 4.58E-02 & $4.72 \mathrm{E}-02$ & $4.81 \mathrm{E}-02$ & 4.83E-02 & $4.80 \mathrm{E}-02$ & $4.70 \mathrm{E}-02$ & 4.55E-02 & 4.34E-02 & 4.07E-02 & $3.76 \mathrm{E}-02$ & $3.39 \mathrm{E}-02$ & $3.00 \mathrm{E}-02$ & 2.67E-02 \\
\hline $\mathrm{ND}$ & 1.15E-01 & 1.23E-01 & 1.34E-01 & 1.44E-01 & 1.53E-01 & 1.60E-01 & $1.65 \mathrm{E}-01$ & 1.68E-01 & 1.69E-01 & 1.68E-01 & 1.64E-01 & 1.59E-01 & $1.51 \mathrm{E}-01$ & 1.42E-01 & $1.31 \mathrm{E}-01$ & 1.18E-01 & 1.05E-01 & $9.26 \mathrm{E}-02$ \\
\hline PM & $6.26 \mathrm{E}-05$ & $6.57 \mathrm{E}-05$ & $7.05 \mathrm{E}-05$ & $7.49 \mathrm{E}-05$ & $7.86 \mathrm{E}-05$ & $8.14 \mathrm{E}-05$ & $8.34 \mathrm{E}-05$ & $8.45 \mathrm{E}-05$ & $8.49 \mathrm{E}-05$ & $8.44 \mathrm{E}-05$ & $8.31 \mathrm{E}-05$ & $8.10 \mathrm{E}-05$ & $7.80 \mathrm{E}-05$ & $7.42 \mathrm{E}-05$ & $6.94 \mathrm{E}-05$ & $6.37 \mathrm{E}-05$ & $5.74 \mathrm{E}-05$ & $5.18 \mathrm{E}-05$ \\
\hline SM & 2.58E-02 & $2.77 \mathrm{E}-02$ & $3.03 E-02$ & 3.28E-02 & $3.49 \mathrm{E}-02$ & $3.66 \mathrm{E}-02$ & $3.78 \mathrm{E}-02$ & $3.85 \mathrm{E}-02$ & $3.87 \mathrm{E}-02$ & $3.84 \mathrm{E}-02$ & $3.76 \mathrm{E}-02$ & 3.63E-02 & $3.46 \mathrm{E}-02$ & $3.24 \mathrm{E}-02$ & $2.97 \mathrm{E}-02$ & $2.67 \mathrm{E}-02$ & 2.36E-02 & 2.07E-02 \\
\hline EU & 1.67E-03 & $1.79 \mathrm{E}-03$ & $1.95 \mathrm{E}-03$ & 2.10E-03 & $2.23 \mathrm{E}-03$ & $2.33 \mathrm{E}-03$ & $2.40 \mathrm{E}-03$ & $2.44 \mathrm{E}-03$ & $2.45 \mathrm{E}-03$ & $2.43 \mathrm{E}-03$ & $2.39 \mathrm{E}-03$ & $2.31 \mathrm{E}-03$ & 2.21E- -03 & $2.08 \mathrm{E}-03$ & $1.92 \mathrm{E}-03$ & 1.73E- 03 & 1.53E-03 & $1.35 \mathrm{E}-03$ \\
\hline $\mathrm{GD}$ & $9.59 \mathrm{E}-04$ & $1.07 \mathrm{E}-03$ & $1.20 \mathrm{E}-03$ & 1.33E-03 & 1.44E-03 & $1.54 \mathrm{E}-03$ & $1.60 \mathrm{E}-03$ & $1.64 \mathrm{E}-03$ & $1.65 \mathrm{E}-03$ & $1.63 \mathrm{E}-03$ & $1.59 \mathrm{E}-03$ & $1.52 \mathrm{E}-03$ & 1.43E- 03 & $1.31 \mathrm{E}-03$ & 1.18E-03 & $1.03 \mathrm{E}-03$ & $8.78 \mathrm{E}-04$ & $7.39 \mathrm{E}-04$ \\
\hline $\mathrm{TB}$ & $3.32 \mathrm{E}-05$ & 3.68E-05 & 4.11E-05 & 4.53E-05 & 4.89E-05 & 5.17E- -05 & $5.38 \mathrm{E}-05$ & $5.50 \mathrm{E}-05$ & $5.53 \mathrm{E}-05$ & $5.48 \mathrm{E}-05$ & $5.34 \mathrm{E}-05$ & $5.12 \mathrm{E}-05$ & 4.82E-05 & 4.45E-05 & $4.02 \mathrm{E}-05$ & 3.55E-05 & $3.05 E-05$ & $2.58 \mathrm{E}-05$ \\
\hline DY & 1.87E-05 & 2.15E-05 & 2.46E-05 & $2.76 \mathrm{E}-05$ & 3.02E-05 & 3.24E-05 & $3.39 \mathrm{E}-05$ & 3.49E-05 & $3.51 \mathrm{E}-05$ & $3.47 \mathrm{E}-05$ & 3.37E-05 & 3.20E-05 & $2.98 \mathrm{E}-05$ & $2.71 \mathrm{E}-05$ & $2.41 \mathrm{E}-05$ & $2.08 \mathrm{E}-05$ & $1.73 \mathrm{E}-05$ & 1.41E-05 \\
\hline $\mathrm{HO}$ & $6.60 \mathrm{E}-07$ & $7.58 \mathrm{E}-07$ & $8.62 \mathrm{E}-07$ & $9.56 \mathrm{E}-07$ & $1.04 \mathrm{E}-06$ & 1.10E-06 & 1.15E-06 & 1. $18 \mathrm{E}-06$ & 1.19E-06 & 1. $18 \mathrm{E}-06$ & 1.14E-06 & $1.09 \mathrm{E}-06$ & 1.03E-06 & $9.42 \mathrm{E}-07$ & $8.45 \mathrm{E}-07$ & $7.38 \mathrm{E}-07$ & $6.23 \mathrm{E}-07$ & 5.07E-07 \\
\hline$E R$ & $6.37 \mathrm{E}-07$ & $7.41 \mathrm{E}-07$ & $8.52 \mathrm{E}-07$ & $9.55 \mathrm{E}-07$ & $1.05 \mathrm{E}-06$ & 1.12E-06 & $1.17 \mathrm{E}-06$ & $1.20 \mathrm{E}-06$ & $1.21 \mathrm{E}-06$ & $1.20 \mathrm{E}-06$ & 1.16E-06 & 1.11E-06 & $1.03 \mathrm{E}-06$ & $9.39 \mathrm{E}-07$ & $8.34 \mathrm{E}-07$ & $7.21 \mathrm{E}-07$ & $6.00 \mathrm{E}-07$ & $4.81 \mathrm{E}-07$ \\
\hline $\begin{array}{l}\text { SUM FPs } \\
\text { elemental }\end{array}$ & 9.50E-01 & $1.01 \mathrm{E}+00$ & 1.11 $\mathrm{E}+00$ & 1. $19 \mathrm{E}+00$ & 1.27E+00 & $1.33 \mathrm{E}+00$ & $1.37 \mathrm{E}+00$ & 1.39E+00 & 1.40E+00 & $1.39 \mathrm{E}+00$ & 1.36E+00 & 1.32E+00 & 1.26E+00 & 1. $18 \mathrm{E}+00$ & $1.08 \mathrm{E}+00$ & $9.78 \mathrm{E}-01$ & $8.65 \mathrm{E}-01$ & $7.65 \mathrm{E}-01$ \\
\hline
\end{tabular}

Position=Segment location (midpoint of 2 -in. segment) from bottom of fuel (BOF); 2 in. of fuel $\sim 14.2 \mathrm{~g}$ 
Table A-2a. Composition (grams) in 2-inch fuel segment: ORIGEN calculation results for Pin 193045, decayed to 3/11/2011.

\begin{tabular}{|c|c|c|c|c|c|c|c|c|c|c|c|c|c|c|c|c|c|c|}
\hline Position: & 1 & 3 & 5 & 7 & 9 & 11 & 13 & 15 & 17 & 19 & 21 & 23 & 25 & 27 & 29 & 31 & 33 & 35 \\
\hline HE 4 & $6.52 \mathrm{E}-06$ & $7.29 \mathrm{E}-06$ & $8.57 \mathrm{E}-06$ & $9.95 \mathrm{E}-06$ & 1.13E-05 & $1.24 \mathrm{E}-05$ & $1.32 \mathrm{E}-05$ & $1.37 \mathrm{E}-05$ & $1.38 \mathrm{E}-05$ & 1.35E-05 & 1.29E-05 & 1.20E-05 & $1.08 \mathrm{E}-05$ & $9.47 \mathrm{E}-06$ & $8.04 \mathrm{E}-06$ & $6.62 \mathrm{E}-06$ & $5.33 \mathrm{E}-06$ & 4.40E-06 \\
\hline $\mathrm{TH} 230$ & $4.98 \mathrm{E}-08$ & $5.72 \mathrm{E}-08$ & $6.37 \mathrm{E}-08$ & $6.94 \mathrm{E}-08$ & 7.41E- 08 & $7.77 \mathrm{E}-08$ & $8.02 \mathrm{E}-08$ & $8.17 \mathrm{E}-08$ & $8.21 \mathrm{E}-08$ & $8.14 \mathrm{E}-08$ & $7.95 \mathrm{E}-08$ & 7.67E-08 & $7.28 \mathrm{E}-08$ & $6.80 \mathrm{E}-08$ & $6.24 \mathrm{E}-08$ & $5.59 \mathrm{E}-08$ & $0.00 \mathrm{E}+00$ & $0.00 \mathrm{E}+00$ \\
\hline TH232 & $1.87 \mathrm{E}-07$ & $1.80 \mathrm{E}-07$ & 1.87E-07 & $1.97 \mathrm{E}-07$ & $2.06 \mathrm{E}-07$ & 2.13E- 07 & $2.18 \mathrm{E}-07$ & $2.21 \mathrm{E}-07$ & $2.21 \mathrm{E}-07$ & $2.20 \mathrm{E}-07$ & 2.16E-07 & $2.10 \mathrm{E}-07$ & $2.02 \mathrm{E}-07$ & $1.91 \mathrm{E}-07$ & $1.79 \mathrm{E}-07$ & $1.65 \mathrm{E}-07$ & 1.52E-07 & 1.49E- -07 \\
\hline PA231 & $6.90 \mathrm{E}-08$ & $6.77 \mathrm{E}-08$ & $6.51 \mathrm{E}-08$ & $6.25 \mathrm{E}-08$ & $6.03 \mathrm{E}-08$ & $5.86 \mathrm{E}-08$ & $5.74 \mathrm{E}-08$ & $5.68 \mathrm{E}-08$ & 5.66E-08 & $5.69 \mathrm{E}-08$ & $5.78 \mathrm{E}-08$ & $5.91 \mathrm{E}-08$ & $6.10 \mathrm{E}-08$ & $6.34 \mathrm{E}-08$ & $6.62 \mathrm{E}-08$ & $6.95 \mathrm{E}-08$ & $7.30 \mathrm{E}-08$ & 7.57E-08 \\
\hline U233 & $0.00 E+00$ & $0.00 \mathrm{E}+00$ & $0.00 \mathrm{E}+00$ & 1.40E-07 & 1.65E-07 & $1.86 \mathrm{E}-07$ & $2.02 E-07$ & 2.11E-07 & 2.13E-07 & $2.09 \mathrm{E}-07$ & $1.97 \mathrm{E}-07$ & 1.79E-07 & 1.57E-07 & $1.32 \mathrm{E}-07$ & $0.00 E+00$ & $0.00 \mathrm{E}+00$ & $0.00 \mathrm{E}+00$ & $0.00 E+00$ \\
\hline U234 & $1.84 \mathrm{E}-06$ & $2.04 \mathrm{E}-06$ & $2.20 \mathrm{E}-06$ & $2.31 \mathrm{E}-06$ & $2.40 \mathrm{E}-06$ & $2.46 \mathrm{E}-06$ & $2.50 \mathrm{E}-06$ & $2.52 \mathrm{E}-06$ & $2.52 \mathrm{E}-06$ & $2.51 \mathrm{E}-06$ & $2.49 \mathrm{E}-06$ & $2.44 \mathrm{E}-06$ & $2.38 \mathrm{E}-06$ & $2.29 \mathrm{E}-06$ & 2.17E- 06 & $2.02 \mathrm{E}-06$ & $1.83 \mathrm{E}-06$ & 1.58E-06 \\
\hline U235 & $9.42 \mathrm{E}-04$ & $1.09 \mathrm{E}-03$ & 1.23E-03 & 1.36E-03 & 1.47E-03 & $1.56 \mathrm{E}-03$ & $1.63 \mathrm{E}-03$ & 1.66E-03 & $1.67 \mathrm{E}-03$ & 1.65E-03 & $1.61 \mathrm{E}-03$ & 1.54E-03 & 1.44E-03 & $1.33 \mathrm{E}-03$ & 1.20E-03 & $1.06 \mathrm{E}-03$ & $9.06 \mathrm{E}-04$ & 7.44E-04 \\
\hline U236 & $3.07 E+00$ & $3.03 E+00$ & $2.92 E+00$ & $2.81 \mathrm{E}+00$ & $2.72 \mathrm{E}+00$ & $2.64 \mathrm{E}+00$ & $2.59 \mathrm{E}+00$ & $2.56 \mathrm{E}+00$ & $2.56 \mathrm{E}+00$ & $2.57 \mathrm{E}+00$ & $2.61 \mathrm{E}+00$ & $2.67 \mathrm{E}+00$ & $2.75 \mathrm{E}+00$ & $2.85 \mathrm{E}+00$ & $2.97 E+00$ & $3.12 \mathrm{E}+00$ & $3.26 \mathrm{E}+00$ & $3.37 \mathrm{E}+00$ \\
\hline U237 & $3.11 \mathrm{E}-01$ & $2.97 \mathrm{E}-01$ & 3.10E-01 & $3.26 \mathrm{E}-01$ & $3.40 \mathrm{E}-01$ & $3.52 \mathrm{E}-01$ & $3.60 \mathrm{E}-01$ & $3.65 \mathrm{E}-01$ & $3.66 \mathrm{E}-01$ & 3.63E-01 & $3.57 \mathrm{E}-01$ & $3.47 \mathrm{E}-01$ & $3.34 \mathrm{E}-01$ & $3.17 \mathrm{E}-01$ & $2.97 \mathrm{E}-01$ & $2.74 \mathrm{E}-01$ & $2.53 \mathrm{E}-01$ & $2.48 \mathrm{E}-01$ \\
\hline U238 & $4.04 \mathrm{E}-12$ & 3.38E-12 & $3.89 \mathrm{E}-12$ & 4.73E- 12 & $5.60 \mathrm{E}-12$ & $6.38 \mathrm{E}-12$ & $7.01 \mathrm{E}-12$ & $7.38 \mathrm{E}-12$ & $7.46 \mathrm{E}-12$ & 7.26E-12 & $6.78 \mathrm{E}-12$ & 6.07E-12 & $5.18 \mathrm{E}-12$ & 4.24E- -12 & 3.31E-12 & $2.47 \mathrm{E}-12$ & 1.87E-12 & $1.80 \mathrm{E}-12$ \\
\hline NP236 & $9.10 \mathrm{E}+00$ & $9.06 \mathrm{E}+00$ & $9.01 E+00$ & $8.97 E+00$ & $8.93 E+00$ & $8.89 \mathrm{E}+00$ & $8.87 E+00$ & $8.86 \mathrm{E}+00$ & $8.85 \mathrm{E}+00$ & $8.86 \mathrm{E}+00$ & $8.88 \mathrm{E}+00$ & $8.90 \mathrm{E}+00$ & $8.94 \mathrm{E}+00$ & $8.98 \mathrm{E}+00$ & $9.03 E+00$ & $9.09 \mathrm{E}+00$ & $9.15 \mathrm{E}+00$ & $9.20 \mathrm{E}+00$ \\
\hline NP237 & $1.79 \mathrm{E}-07$ & $2.32 E-07$ & $3.02 E-07$ & $3.77 \mathrm{E}-07$ & 4.48E-07 & $5.10 \mathrm{E}-07$ & $5.57 \mathrm{E}-07$ & $5.85 \mathrm{E}-07$ & $5.92 \mathrm{E}-07$ & $5.78 \mathrm{E}-07$ & $5.43 \mathrm{E}-07$ & 4.91E-07 & 4.26E-07 & 3.53E-07 & 2.79E- 07 & 2.07E-07 & 1.45E-07 & $0.00 \mathrm{E}+00$ \\
\hline PU238 & $1.48 \mathrm{E}-02$ & 1.64E-02 & $1.90 \mathrm{E}-02$ & 2.16E-02 & 2.39E- 02 & $2.58 \mathrm{E}-02$ & $2.71 \mathrm{E}-02$ & $2.79 \mathrm{E}-02$ & $2.81 \mathrm{E}-02$ & $2.77 \mathrm{E}-02$ & $2.67 \mathrm{E}-02$ & $2.52 \mathrm{E}-02$ & $2.31 \mathrm{E}-02$ & $2.07 \mathrm{E}-02$ & $1.79 \mathrm{E}-02$ & $1.50 \mathrm{E}-02$ & 1.22E-02 & $9.97 \mathrm{E}-03$ \\
\hline PU239 & $9.65 \mathrm{E}-04$ & 1.23E-03 & 1.59E-03 & $1.97 \mathrm{E}-03$ & $2.33 \mathrm{E}-03$ & $2.64 \mathrm{E}-03$ & $2.87 \mathrm{E}-03$ & $3.01 \mathrm{E}-03$ & $3.04 \mathrm{E}-03$ & $2.97 \mathrm{E}-03$ & $2.80 \mathrm{E}-03$ & $2.54 \mathrm{E}-03$ & $2.22 \mathrm{E}-03$ & $1.85 \mathrm{E}-03$ & $1.47 \mathrm{E}-03$ & $1.11 \mathrm{E}-03$ & $7.80 \mathrm{E}-04$ & $5.26 \mathrm{E}-04$ \\
\hline PU240 & $3.19 \mathrm{E}-01$ & $3.25 \mathrm{E}-01$ & $3.45 \mathrm{E}-01$ & 3.66E-01 & $3.85 \mathrm{E}-01$ & $3.99 \mathrm{E}-01$ & $4.09 \mathrm{E}-01$ & 4.15E-01 & 4.16E-01 & 4.13E-01 & 4.06E-01 & $3.94 \mathrm{E}-01$ & $3.77 \mathrm{E}-01$ & $3.57 \mathrm{E}-01$ & 3.33E-01 & $3.05 \mathrm{E}-01$ & $2.77 \mathrm{E}-01$ & $2.57 \mathrm{E}-01$ \\
\hline PU241 & $1.37 \mathrm{E}-02$ & 1.22E- 02 & $1.34 \mathrm{E}-02$ & $1.52 \mathrm{E}-02$ & 1.70E-02 & $1.85 \mathrm{E}-02$ & $1.97 \mathrm{E}-02$ & $2.04 \mathrm{E}-02$ & $2.05 \mathrm{E}-02$ & $2.01 \mathrm{E}-02$ & $1.93 \mathrm{E}-02$ & 1.79E-02 & $1.61 \mathrm{E}-02$ & $1.41 \mathrm{E}-02$ & 1.20E-02 & $9.90 \mathrm{E}-03$ & $8.24 \mathrm{E}-03$ & $8.03 \mathrm{E}-03$ \\
\hline PU242 & $1.30 \mathrm{E}-04$ & $1.09 \mathrm{E}-04$ & 1.26E-04 & 1.53E-04 & 1.81E-04 & $2.06 \mathrm{E}-04$ & $2.26 \mathrm{E}-04$ & $2.38 \mathrm{E}-04$ & $2.41 \mathrm{E}-04$ & 2.34E-04 & $2.19 \mathrm{E}-04$ & 1.96E-04 & 1.67E-04 & $1.37 \mathrm{E}-04$ & $1.07 \mathrm{E}-04$ & $7.98 \mathrm{E}-05$ & $6.04 \mathrm{E}-05$ & $5.82 \mathrm{E}-05$ \\
\hline AM241 & $5.37 \mathrm{E}-06$ & 4.28E-06 & $5.25 \mathrm{E}-06$ & $6.88 \mathrm{E}-06$ & $8.70 \mathrm{E}-06$ & $1.04 \mathrm{E}-05$ & 1.19E-05 & $1.28 \mathrm{E}-05$ & $1.30 \mathrm{E}-05$ & $1.25 \mathrm{E}-05$ & 1.14E-05 & $9.75 E-06$ & $7.83 \mathrm{E}-06$ & $5.94 \mathrm{E}-06$ & 4.22E- 06 & 2.82E- 06 & $1.91 \mathrm{E}-06$ & $1.79 \mathrm{E}-06$ \\
\hline CM242 & $2.03 \mathrm{E}-04$ & $1.70 \mathrm{E}-04$ & 1.96E-04 & 2.38E-04 & $2.81 \mathrm{E}-04$ & $3.20 \mathrm{E}-04$ & $3.52 \mathrm{E}-04$ & $3.70 \mathrm{E}-04$ & $3.75 \mathrm{E}-04$ & $3.64 \mathrm{E}-04$ & $3.40 \mathrm{E}-04$ & $3.05 \mathrm{E}-04$ & $2.60 \mathrm{E}-04$ & $2.13 \mathrm{E}-04$ & 1.66E-04 & $1.24 \mathrm{E}-04$ & $9.40 \mathrm{E}-05$ & $9.05 \mathrm{E}-05$ \\
\hline $\begin{array}{l}\text { SUM HM } \\
\text { isotpes }\end{array}$ & $1.20 \mathrm{E}-07$ & $0.00 \mathrm{E}+00$ & $1.51 \mathrm{E}-07$ & $1.99 \mathrm{E}-07$ & $2.50 \mathrm{E}-07$ & $2.99 \mathrm{E}-07$ & $3.38 \mathrm{E}-07$ & $3.61 \mathrm{E}-07$ & 3.67E-07 & 3.53E-07 & $3.23 \mathrm{E}-07$ & $2.80 \mathrm{E}-07$ & 2.27E-07 & $1.74 \mathrm{E}-07$ & $1.25 \mathrm{E}-07$ & $0.00 \mathrm{E}+00$ & $0.00 E+00$ & $0.00 \mathrm{E}+00$ \\
\hline
\end{tabular}

Position=Segment location (midpoint of 2-in. segment) from bottom of fuel (BOF); sample wgt. 14.2g 
Table A-2b. Composition (grams) in 2-inch fuel segment: ORIGEN calculation results for Pin193045, decayed to 3/11/2011.

\begin{tabular}{|c|c|c|c|c|c|c|c|c|c|c|c|c|c|c|c|c|c|c|}
\hline Position: & 1 & 3 & 5 & 7 & 9 & 11 & 13 & 15 & 17 & 19 & 21 & 23 & 25 & 27 & 29 & 31 & 33 & 35 \\
\hline $\mathrm{HE}$ & $6.52 \mathrm{E}-06$ & $7.29 \mathrm{E}-06$ & $8.57 \mathrm{E}-06$ & $9.95 \mathrm{E}-06$ & 1.13E-05 & $1.24 \mathrm{E}-05$ & 1.32E- 05 & $1.37 \mathrm{E}-05$ & 1.38E-05 & $1.35 \mathrm{E}-05$ & 1.29E-05 & 1.20E-05 & $1.08 \mathrm{E}-05$ & $9.47 \mathrm{E}-06$ & $8.04 \mathrm{E}-06$ & $6.62 \mathrm{E}-06$ & 5.33E- -06 & $4.40 \mathrm{E}-06$ \\
\hline $\mathrm{TH}$ & $2.39 \mathrm{E}-07$ & $2.39 \mathrm{E}-07$ & $2.54 \mathrm{E}-07$ & $2.70 \mathrm{E}-07$ & $2.85 \mathrm{E}-07$ & $2.96 \mathrm{E}-07$ & $3.04 \mathrm{E}-07$ & $3.08 \mathrm{E}-07$ & $3.09 \mathrm{E}-07$ & 3.07E-07 & $3.01 \mathrm{E}-07$ & $2.92 \mathrm{E}-07$ & $2.79 \mathrm{E}-07$ & $2.63 \mathrm{E}-07$ & $2.45 \mathrm{E}-07$ & $2.24 \mathrm{E}-07$ & $2.03 \mathrm{E}-07$ & $1.91 \mathrm{E}-07$ \\
\hline PA & $6.95 \mathrm{E}-08$ & $6.83 \mathrm{E}-08$ & $6.57 \mathrm{E}-08$ & $6.32 \mathrm{E}-08$ & $6.11 \mathrm{E}-08$ & $5.95 \mathrm{E}-08$ & 5.84E- 08 & $5.77 \mathrm{E}-08$ & $5.76 \mathrm{E}-08$ & $5.79 \mathrm{E}-08$ & 5.87E- 08 & $6.00 \mathrm{E}-08$ & $6.18 \mathrm{E}-08$ & $6.41 \mathrm{E}-08$ & $6.68 \mathrm{E}-08$ & $7.00 \mathrm{E}-08$ & 7.34E-08 & $7.61 \mathrm{E}-08$ \\
\hline U & $1.25 \mathrm{E}+01$ & $1.24 \mathrm{E}+01$ & $1.22 \mathrm{E}+01$ & $1.21 \mathrm{E}+01$ & $1.20 \mathrm{E}+01$ & $1.19 \mathrm{E}+01$ & 1.18E+01 & 1. $18 \mathrm{E}+01$ & $1.18 \mathrm{E}+01$ & 1. $18 \mathrm{E}+01$ & 1.18E+01 & 1. $19 \mathrm{E}+01$ & $1.20 \mathrm{E}+01$ & 1.22E +01 & 1.23E+01 & $1.25 \mathrm{E}+01$ & 1.27E+01 & $1.28 \mathrm{E}+01$ \\
\hline $\mathrm{NP}$ & $1.48 \mathrm{E}-02$ & $1.64 \mathrm{E}-02$ & $1.90 \mathrm{E}-02$ & 2.16E-02 & $2.39 \mathrm{E}-02$ & $2.58 \mathrm{E}-02$ & $2.71 \mathrm{E}-02$ & 2.79E-02 & $2.81 \mathrm{E}-02$ & $2.77 \mathrm{E}-02$ & $2.67 \mathrm{E}-02$ & 2.52E-02 & $2.31 \mathrm{E}-02$ & $2.07 \mathrm{E}-02$ & $1.79 \mathrm{E}-02$ & $1.50 \mathrm{E}-02$ & 1.22E-02 & $9.97 \mathrm{E}-03$ \\
\hline PU & $3.34 \mathrm{E}-01$ & $3.39 \mathrm{E}-01$ & $3.60 \mathrm{E}-01$ & $3.84 \mathrm{E}-01$ & 4.04E-01 & $4.20 \mathrm{E}-01$ & 4.32E-01 & 4.38E-01 & $4.40 \mathrm{E}-01$ & 4.36E-01 & 4.28E-01 & 4.14E-01 & $3.96 \mathrm{E}-01$ & $3.73 \mathrm{E}-01$ & $3.46 \mathrm{E}-01$ & $3.16 \mathrm{E}-01$ & $2.86 \mathrm{E}-01$ & $2.66 \mathrm{E}-01$ \\
\hline AM & $2.03 \mathrm{E}-04$ & $1.70 \mathrm{E}-04$ & $1.96 \mathrm{E}-04$ & $2.38 \mathrm{E}-04$ & $2.82 \mathrm{E}-04$ & $3.21 \mathrm{E}-04$ & $3.52 \mathrm{E}-04$ & $3.71 \mathrm{E}-04$ & $3.75 \mathrm{E}-04$ & $3.65 \mathrm{E}-04$ & $3.41 \mathrm{E}-04$ & $3.05 E-04$ & $2.61 \mathrm{E}-04$ & $2.13 \mathrm{E}-04$ & $1.67 \mathrm{E}-04$ & 1.24E-04 & $9.40 \mathrm{E}-05$ & $9.05 \mathrm{E}-05$ \\
\hline $\mathrm{CM}$ & $2.12 \mathrm{E}-09$ & 2.34E-09 & 3.46E-09 & $5.16 \mathrm{E}-09$ & 7.18E-09 & 9.23E-09 & $1.10 \mathrm{E}-08$ & $1.21 \mathrm{E}-08$ & $1.24 \mathrm{E}-08$ & 1.18E-08 & $1.04 \mathrm{E}-08$ & 8.47E-09 & $6.35 \mathrm{E}-09$ & 4.38E-09 & $2.76 \mathrm{E}-09$ & 1.59E-09 & $0.00 \mathrm{E}+00$ & $0.00 E+00$ \\
\hline $\begin{array}{l}\text { SUM HM } \\
\text { elements }\end{array}$ & $1.28 \mathrm{E}+01$ & $1.27 E+01$ & $1.26 \mathrm{E}+01$ & 1.25E+01 & $1.24 E+01$ & $1.23 E+01$ & $1.23 \mathrm{E}+01$ & $1.22 E+01$ & $1.22 \mathrm{E}+01$ & $1.23 E+01$ & 1.23E+01 & $1.24 \mathrm{E}+01$ & $1.24 \mathrm{E}+01$ & $1.25 \mathrm{E}+01$ & $1.27 E+01$ & $1.28 \mathrm{E}+01$ & $1.30 E+01$ & $1.31 \mathrm{E}+01$ \\
\hline $\mathrm{H} 3$ & $1.05 \mathrm{E}-06$ & 1.11E-06 & 1.21E-06 & 1.30E-06 & 1.38E-06 & $1.44 \mathrm{E}-06$ & $1.48 \mathrm{E}-06$ & $1.51 \mathrm{E}-06$ & $1.51 \mathrm{E}-06$ & $1.50 \mathrm{E}-06$ & $1.47 \mathrm{E}-06$ & 1.42E-06 & $1.36 \mathrm{E}-06$ & $1.27 \mathrm{E}-06$ & 1. $18 \mathrm{E}-06$ & $1.06 \mathrm{E}-06$ & $9.41 \mathrm{E}-07$ & $8.36 \mathrm{E}-07$ \\
\hline LI 6 & $1.60 \mathrm{E}-08$ & 1.69E-08 & 1.83E- 08 & $1.96 \mathrm{E}-08$ & $2.07 \mathrm{E}-08$ & $2.15 \mathrm{E}-08$ & $2.21 \mathrm{E}-08$ & 2.24E-08 & $2.25 \mathrm{E}-08$ & 2.23E- 08 & 2.19E- 08 & 2.12E-08 & $2.03 \mathrm{E}-08$ & $1.92 \mathrm{E}-08$ & $1.77 \mathrm{E}-08$ & $1.61 \mathrm{E}-08$ & 1.44E-08 & $1.29 \mathrm{E}-08$ \\
\hline GE 72 & $2.44 \mathrm{E}-06$ & $2.64 \mathrm{E}-06$ & $2.89 \mathrm{E}-06$ & $3.11 \mathrm{E}-06$ & $3.30 \mathrm{E}-06$ & $3.45 \mathrm{E}-06$ & $3.55 \mathrm{E}-06$ & $3.61 \mathrm{E}-06$ & $3.63 \mathrm{E}-06$ & $3.60 \mathrm{E}-06$ & 3.52E-06 & $3.41 \mathrm{E}-06$ & $3.25 \mathrm{E}-06$ & $3.04 \mathrm{E}-06$ & $2.80 \mathrm{E}-06$ & $2.53 \mathrm{E}-06$ & 2.22E-06 & $1.94 \mathrm{E}-06$ \\
\hline GE 73 & $6.07 E-06$ & $6.47 \mathrm{E}-06$ & $7.03 \mathrm{E}-06$ & $7.55 \mathrm{E}-06$ & $7.98 \mathrm{E}-06$ & $8.31 \mathrm{E}-06$ & $8.54 \mathrm{E}-06$ & $8.66 \mathrm{E}-06$ & $8.70 \mathrm{E}-06$ & $8.63 \mathrm{E}-06$ & $8.47 \mathrm{E}-06$ & $8.20 \mathrm{E}-06$ & $7.84 \mathrm{E}-06$ & $7.38 \mathrm{E}-06$ & $6.83 \mathrm{E}-06$ & $6.20 \mathrm{E}-06$ & $5.50 \mathrm{E}-06$ & 4.87E-06 \\
\hline GE 74 & $1.22 \mathrm{E}-05$ & $1.30 \mathrm{E}-05$ & $1.41 \mathrm{E}-05$ & 1.52E-05 & $1.61 \mathrm{E}-05$ & $1.68 \mathrm{E}-05$ & 1.73E-05 & 1.76E-05 & $1.77 \mathrm{E}-05$ & $1.75 \mathrm{E}-05$ & 1.72E- 05 & 1.66E-05 & 1.58E-05 & 1.49E-05 & $1.37 \mathrm{E}-05$ & $1.24 \mathrm{E}-05$ & 1.10E-05 & $9.70 \mathrm{E}-06$ \\
\hline AS 75 & $2.04 \mathrm{E}-05$ & 2.16E-05 & $2.35 \mathrm{E}-05$ & $2.51 \mathrm{E}-05$ & $2.66 \mathrm{E}-05$ & $2.76 \mathrm{E}-05$ & $2.84 \mathrm{E}-05$ & $2.88 \mathrm{E}-05$ & $2.89 \mathrm{E}-05$ & $2.87 \mathrm{E}-05$ & 2.82E- 05 & 2.73E-05 & $2.61 \mathrm{E}-05$ & $2.46 \mathrm{E}-05$ & 2.28E-05 & 2.07E-05 & 1.84E-05 & $1.64 \mathrm{E}-05$ \\
\hline GE 76 & $4.78 \mathrm{E}-05$ & $5.06 \mathrm{E}-05$ & $5.49 \mathrm{E}-05$ & $5.90 \mathrm{E}-05$ & $6.24 \mathrm{E}-05$ & $6.50 \mathrm{E}-05$ & $6.69 \mathrm{E}-05$ & $6.79 \mathrm{E}-05$ & $6.82 \mathrm{E}-05$ & $6.76 \mathrm{E}-05$ & $6.63 \mathrm{E}-05$ & $6.42 \mathrm{E}-05$ & $6.13 \mathrm{E}-05$ & $5.77 \mathrm{E}-05$ & 5.33E-05 & $4.83 \mathrm{E}-05$ & 4.29E-05 & $3.82 \mathrm{E}-05$ \\
\hline SE 76 & $5.08 \mathrm{E}-07$ & $6.26 \mathrm{E}-07$ & $7.69 \mathrm{E}-07$ & $9.09 E-07$ & $1.04 \mathrm{E}-06$ & 1.14E-06 & 1.22E- 06 & 1.26E-06 & $1.27 \mathrm{E}-06$ & $1.25 \mathrm{E}-06$ & 1.20E-06 & 1.11E-06 & $9.99 \mathrm{E}-07$ & $8.69 \mathrm{E}-07$ & $7.28 \mathrm{E}-07$ & $5.82 E-07$ & 4.41E-07 & $3.20 \mathrm{E}-07$ \\
\hline SE 77 & $9.46 \mathrm{E}-05$ & $9.96 \mathrm{E}-05$ & 1.08E-04 & 1.15E-04 & 1.22E-04 & $1.26 \mathrm{E}-04$ & 1.30E-04 & 1.32E- 04 & $1.32 \mathrm{E}-04$ & $1.31 \mathrm{E}-04$ & 1.29E-04 & 1.25E-04 & 1.20E-04 & 1.13E-04 & $1.04 \mathrm{E}-04$ & 9.49E-05 & 8.47E-05 & $7.60 \mathrm{E}-05$ \\
\hline SE 78 & $1.94 \mathrm{E}-04$ & $2.04 \mathrm{E}-04$ & $2.21 \mathrm{E}-04$ & $2.38 \mathrm{E}-04$ & $2.52 \mathrm{E}-04$ & $2.63 \mathrm{E}-04$ & $2.70 \mathrm{E}-04$ & $2.75 \mathrm{E}-04$ & $2.76 \mathrm{E}-04$ & $2.73 \mathrm{E}-04$ & $2.68 \mathrm{E}-04$ & 2.59E-04 & $2.47 \mathrm{E}-04$ & $2.32 \mathrm{E}-04$ & $2.15 \mathrm{E}-04$ & 1.94E-04 & 1.73E-04 & $1.54 \mathrm{E}-04$ \\
\hline SE 79 & $2.94 \mathrm{E}-04$ & $3.13 \mathrm{E}-04$ & 3.40E-04 & $3.66 \mathrm{E}-04$ & 3.87E-04 & 4.04E-04 & 4.16E-04 & 4.23E-04 & $4.24 \mathrm{E}-04$ & $4.21 \mathrm{E}-04$ & 4.12E-04 & $3.99 \mathrm{E}-04$ & $3.81 \mathrm{E}-04$ & $3.57 \mathrm{E}-04$ & $3.30 \mathrm{E}-04$ & $2.98 \mathrm{E}-04$ & 2.64E-04 & 2.35E-04 \\
\hline BR 79 & $6.49 \mathrm{E}-08$ & $6.90 \mathrm{E}-08$ & $7.50 \mathrm{E}-08$ & $8.07 \mathrm{E}-08$ & $8.55 \mathrm{E}-08$ & $8.92 \mathrm{E}-08$ & $9.18 \mathrm{E}-08$ & $9.32 \mathrm{E}-08$ & $9.36 \mathrm{E}-08$ & $9.28 \mathrm{E}-08$ & $9.10 \mathrm{E}-08$ & $8.80 \mathrm{E}-08$ & $8.39 \mathrm{E}-08$ & $7.88 \mathrm{E}-08$ & $7.27 \mathrm{E}-08$ & $6.58 \mathrm{E}-08$ & $5.83 \mathrm{E}-08$ & $5.17 \mathrm{E}-08$ \\
\hline
\end{tabular}

lxxxi 


\begin{tabular}{|c|c|c|c|c|c|c|c|c|c|c|c|c|c|c|c|c|c|c|}
\hline SE 80 & & & & & & & & & & & & & & & & & & \\
\hline & $6.29 E-04$ & $6.64 \mathrm{E}-04$ & $7.19 \mathrm{E}-04$ & $7.72 E-04$ & $8.16 \mathrm{E}-04$ & $8.50 \mathrm{E}-04$ & $8.74 \mathrm{E}-04$ & $8.88 \mathrm{E}-04$ & $8.91 \mathrm{E}-04$ & $8.84 \mathrm{E}-04$ & $8.67 \mathrm{E}-04$ & $8.39 E-04$ & $8.02 E-04$ & $7.55 \mathrm{E}-04$ & $6.98 \mathrm{E}-04$ & $6.33 \mathrm{E}-04$ & $5.63 \mathrm{E}-04$ & $5.04 \mathrm{E}-04$ \\
\hline BR 81 & $9.94 \mathrm{E}-04$ & $1.05 \mathrm{E}-03$ & $1.13 \mathrm{E}-03$ & $1.21 \mathrm{E}-03$ & $1.28 \mathrm{E}-03$ & $1.33 \mathrm{E}-03$ & $1.37 E-03$ & $1.39 \mathrm{E}-03$ & $1.39 \mathrm{E}-03$ & $1.38 E-03$ & $1.35 \mathrm{E}-03$ & $1.31 \mathrm{E}-03$ & $1.26 \mathrm{E}-03$ & $1.19 \mathrm{E}-03$ & 1.10E -03 & $1.00 E-03$ & $8.93 E-04$ & $8.00 \mathrm{E}-04$ \\
\hline SE 82 & $1.46 \mathrm{E}-03$ & & -03 & & $1.91 \mathrm{E}-03$ & $1.99 E-03$ & $2.04 \mathrm{E}-03$ & 03 & $2.08 \mathrm{E}-03$ & $2.07 E-03$ & BE-03 & $1.96 \mathrm{E}-03$ & $37 E-03$ & $1.76 \mathrm{E}-03$ & $1.63 \mathrm{E}-03$ & $1.47 \mathrm{E}-03$ & $1.31 E-03$ & 1.16E-03 \\
\hline
\end{tabular}

Position=Segment location (midpoint of 2-in. segment) from bottom of fuel (BOF); 2 -in of fuel $\sim 14.2 \mathrm{~g}$ 
Table A-2c. Composition (grams) in 2-inch fuel segment: ORIGEN calculation results for Pin 193045, decayed to 3/11/2011.

\begin{tabular}{|c|c|c|c|c|c|c|c|c|c|c|c|c|c|c|c|c|c|c|}
\hline Position: & 1 & 3 & 5 & 7 & 9 & 11 & 13 & 15 & 17 & 19 & 21 & 23 & 25 & 27 & 29 & 31 & 33 & 35 \\
\hline KR 82 & $3.09 \mathrm{E}-05$ & 3.76E-05 & 4.59E-05 & $5.41 \mathrm{E}-05$ & $6.14 \mathrm{E}-05$ & $6.75 \mathrm{E}-05$ & $7.19 \mathrm{E}-05$ & $7.45 \mathrm{E}-05$ & $7.51 \mathrm{E}-05$ & $7.38 \mathrm{E}-05$ & $7.06 \mathrm{E}-05$ & $6.57 \mathrm{E}-05$ & $5.93 \mathrm{E}-05$ & 5.17E-05 & 4.34E- 05 & $3.49 \mathrm{E}-05$ & $2.66 \mathrm{E}-05$ & $1.96 \mathrm{E}-05$ \\
\hline KR 83 & $2.48 \mathrm{E}-03$ & $2.62 \mathrm{E}-03$ & $2.83 \mathrm{E}-03$ & $3.02 \mathrm{E}-03$ & 3.19E-03 & $3.32 \mathrm{E}-03$ & $3.40 \mathrm{E}-03$ & $3.45 \mathrm{E}-03$ & $3.47 \mathrm{E}-03$ & 3.44E-03 & $3.38 \mathrm{E}-03$ & $3.28 \mathrm{E}-03$ & $3.14 \mathrm{E}-03$ & $2.96 \mathrm{E}-03$ & $2.74 \mathrm{E}-03$ & $2.50 \mathrm{E}-03$ & $2.23 \mathrm{E}-03$ & $2.00 \mathrm{E}-03$ \\
\hline KR 84 & $4.85 \mathrm{E}-03$ & $4 \mathrm{E}-03$ & $59 \mathrm{E}-03$ & $6.01 \mathrm{E}-03$ & $6.37 \mathrm{E}-03$ & $65 \mathrm{E}-03$ & $6.85 \mathrm{E}-03$ & $6.96 \mathrm{E}-03$ & $6.99 \mathrm{E}-03$ & $6.93 \mathrm{E}-03$ & $6.79 \mathrm{E}-03$ & $6.57 \mathrm{E}-03$ & $6.26 \mathrm{E}-03$ & $5.87 \mathrm{E}-03$ & $5.42 \mathrm{E}-03$ & $4.89 \mathrm{E}-03$ & $4.34 \mathrm{E}-03$ & $3.86 \mathrm{E}-03$ \\
\hline KR 85 & 3.28E-04 & $3.46 \mathrm{E}-04$ & $3.76 \mathrm{E}-04$ & 4.04E-04 & $4.28 \mathrm{E}-04$ & $4.46 \mathrm{E}-04$ & 4.59E-04 & 4.66E-04 & 4.68E-04 & $4.64 \mathrm{E}-04$ & $4.55 \mathrm{E}-04$ & $4.40 \mathrm{E}-04$ & 4.20E-04 & $3.95 \mathrm{E}-04$ & $3.65 \mathrm{E}-04$ & $3.30 \mathrm{E}-04$ & $2.93 \mathrm{E}-04$ & 2.62E-04 \\
\hline RB 85 & $5.43 \mathrm{E}-03$ & $5.72 \mathrm{E}-03$ & $6.19 \mathrm{E}-03$ & $6.64 \mathrm{E}-03$ & $7.01 \mathrm{E}-03$ & $7.30 \mathrm{E}-03$ & $7.51 \mathrm{E}-03$ & $7.62 \mathrm{E}-03$ & $7.65 \mathrm{E}-03$ & $7.59 \mathrm{E}-03$ & $7.45 \mathrm{E}-03$ & $7.21 \mathrm{E}-03$ & $6.89 \mathrm{E}-03$ & $6.49 \mathrm{E}-03$ & $6.01 \mathrm{E}-03$ & $5.45 \mathrm{E}-03$ & $4.85 \mathrm{E}-03$ & 4.35E-03 \\
\hline KR 86 & $8.99 \mathrm{E}-03$ & $9.48 \mathrm{E}-03$ & $1.03 \mathrm{E}-02$ & 1.10E-02 & 1.17E-02 & 1.22E-02 & $1.25 \mathrm{E}-02$ & $1.27 \mathrm{E}-02$ & 1.28E-02 & 1.27E-02 & 1.24E-02 & 1.20E-02 & 1.15E-02 & $1.08 \mathrm{E}-02$ & $9.97 \mathrm{E}-03$ & $9.03 \mathrm{E}-03$ & $8.03 \mathrm{E}-03$ & $7.19 \mathrm{E}-03$ \\
\hline RB 86 & $0.00 \mathrm{E}+00$ & $00 \mathrm{E}+00$ & $0.00 \mathrm{E}+00$ & $0.00 \mathrm{E}+00$ & $0.00 \mathrm{E}+00$ & $0.00 \mathrm{E}+00$ & $0.00 \mathrm{E}+00$ & $0.00 E+00$ & $0.00 E+00$ & $0.00 \mathrm{E}+00$ & $0.00 \mathrm{E}+00$ & $0.00 \mathrm{E}+00$ & $0.00 \mathrm{E}+00$ & $0.00 \mathrm{E}+00$ & $0.00 \mathrm{E}+00$ & $0.00 E+00$ & $0.00 \mathrm{E}+00$ & $0.00 E+00$ \\
\hline SR 86 & $6.90 \mathrm{E}-05$ & $8.43 \mathrm{E}-05$ & 1.03E-04 & 1.22E-04 & $1.39 \mathrm{E}-04$ & $1.53 \mathrm{E}-04$ & 1.63E-04 & $1.69 \mathrm{E}-04$ & $1.71 \mathrm{E}-04$ & $1.68 \mathrm{E}-04$ & 1.60E-04 & 1.49E-04 & $1.34 \mathrm{E}-04$ & 1.17E-04 & $9.75 \mathrm{E}-05$ & $7.80 \mathrm{E}-05$ & $5.93 \mathrm{E}-05$ & 4.34E-05 \\
\hline RB 87 & 1.14E-02 & 1.21E-02 & 1.31E-02 & 1.40E-02 & 1.48E-02 & $1.55 \mathrm{E}-02$ & 1.59E-02 & $1.62 \mathrm{E}-02$ & 1.62E-02 & $1.61 \mathrm{E}-02$ & 1.58E-02 & $1.53 \mathrm{E}-02$ & 1.46E-02 & $1.37 \mathrm{E}-02$ & 1.27E-02 & 1.15E-02 & $1.02 \mathrm{E}-02$ & $9.15 \mathrm{E}-03$ \\
\hline SR 87 & $3.45 \mathrm{E}-07$ & 4.43E- 07 & 5.74E-07 & $7.16 \mathrm{E}-07$ & $8.53 \mathrm{E}-07$ & $9.73 \mathrm{E}-07$ & $1.06 \mathrm{E}-06$ & 1.12E-06 & 1.13E-06 & 1.11E-06 & 1.04E-06 & $9.37 \mathrm{E}-07$ & $8.13 \mathrm{E}-07$ & $6.75 \mathrm{E}-07$ & $5.36 \mathrm{E}-07$ & $4.05 \mathrm{E}-07$ & 2.92E-07 & $2.08 \mathrm{E}-07$ \\
\hline SR 88 & $1.68 \mathrm{E}-02$ & $1.78 \mathrm{E}-02$ & $1.92 \mathrm{E}-02$ & $2.06 \mathrm{E}-02$ & $2.18 \mathrm{E}-02$ & $2.27 \mathrm{E}-02$ & 2.34E-02 & $2.38 \mathrm{E}-02$ & $2.38 \mathrm{E}-02$ & $2.37 \mathrm{E}-02$ & 2.32E-02 & $2.25 \mathrm{E}-02$ & $2.14 \mathrm{E}-02$ & $2.02 \mathrm{E}-02$ & $1.87 \mathrm{E}-02$ & $1.69 \mathrm{E}-02$ & $1.50 \mathrm{E}-02$ & $1.35 \mathrm{E}-02$ \\
\hline SR 89 & 1.12E-42 & 1.25E-42 & 1.37E-42 & 1.37E-42 & $1.50 \mathrm{E}-42$ & $1.50 \mathrm{E}-42$ & 1.50E-42 & $1.50 \mathrm{E}-42$ & $1.50 \mathrm{E}-42$ & 1.50E-42 & 1.50E-42 & $1.50 \mathrm{E}-42$ & $1.50 \mathrm{E}-42$ & $1.37 \mathrm{E}-42$ & $1.25 \mathrm{E}-42$ & $1.25 \mathrm{E}-42$ & 1.12E-42 & $9.98 \mathrm{E}-43$ \\
\hline Y 89 & 2.12E-02 & 2.24E-02 & 2.43E-02 & 2.60E-02 & $2.75 \mathrm{E}-02$ & 2.87E-02 & $2.95 \mathrm{E}-02$ & $2.99 \mathrm{E}-02$ & $3.01 \mathrm{E}-02$ & $2.98 \mathrm{E}-02$ & $2.92 \mathrm{E}-02$ & 2.83E-02 & 2.71E-02 & $2.55 \mathrm{E}-02$ & $2.35 \mathrm{E}-02$ & 2.13E-02 & $1.90 \mathrm{E}-02$ & $1.70 \mathrm{E}-02$ \\
\hline SR 9 & $1.57 \mathrm{E}-02$ & $1.65 \mathrm{E}-02$ & $1.79 \mathrm{E}-02$ & $1.92 \mathrm{E}-02$ & $2.03 E-02$ & 2.11E-02 & 2.17E-02 & $2.20 \mathrm{E}-02$ & $2.21 \mathrm{E}-02$ & $2.20 \mathrm{E}-02$ & $2.15 \mathrm{E}-02$ & $2.09 \mathrm{E}-02$ & $1.99 \mathrm{E}-02$ & $1.87 \mathrm{E}-02$ & $1.73 \mathrm{E}-02$ & $1.57 \mathrm{E}-02$ & $1.40 \mathrm{E}-02$ & $1.25 \mathrm{E}-02$ \\
\hline Y 90 & $3.93 \mathrm{E}-06$ & 4.14E- 06 & 4.48E-06 & $4.81 \mathrm{E}-06$ & $5.08 \mathrm{E}-06$ & $5.30 \mathrm{E}-06$ & $5.44 \mathrm{E}-06$ & $5.53 \mathrm{E}-06$ & $5.55 \mathrm{E}-06$ & $5.51 \mathrm{E}-06$ & $5.40 \mathrm{E}-06$ & $5.23 \mathrm{E}-06$ & $5.00 \mathrm{E}-06$ & $4.70 \mathrm{E}-06$ & $4.35 \mathrm{E}-06$ & $3.94 \mathrm{E}-06$ & $3.51 \mathrm{E}-06$ & $3.15 \mathrm{E}-06$ \\
\hline ZR 90 & $1.03 E-02$ & $1.08 \mathrm{E}-02$ & 1.17E-02 & 1.26E-02 & $1.33 \mathrm{E}-02$ & $1.39 \mathrm{E}-02$ & $1.43 \mathrm{E}-02$ & $1.45 \mathrm{E}-02$ & $1.46 \mathrm{E}-02$ & 1.45E-02 & 1.42E-02 & $1.37 \mathrm{E}-02$ & $1.31 \mathrm{E}-02$ & $1.23 \mathrm{E}-02$ & 1.14E-02 & $1.03 \mathrm{E}-02$ & $9.16 \mathrm{E}-03$ & $8.20 \mathrm{E}-03$ \\
\hline Y 91 & $3.80 \mathrm{E}-37$ & $3.97 E-37$ & 4.24E- 37 & 4.49E-37 & $4.70 \mathrm{E}-37$ & $4.85 \mathrm{E}-37$ & $4.95 E-37$ & $5.02 \mathrm{E}-37$ & $5.03 E-37$ & $5.01 \mathrm{E}-37$ & 4.94E-37 & $4.83 \mathrm{E}-37$ & 4.67E-37 & 4.45E- 37 & $4.18 \mathrm{E}-37$ & $3.86 \mathrm{E}-37$ & 3.49E- 37 & 3.18E-37 \\
\hline ZR 9 & $2.69 \mathrm{E}-02$ & $2.84 \mathrm{E}-02$ & $3.07 \mathrm{E}-02$ & $3.30 \mathrm{E}-02$ & $3.49 \mathrm{E}-02$ & 3.63E-02 & $3.73 \mathrm{E}-02$ & $3.79 \mathrm{E}-02$ & $3.81 \mathrm{E}-02$ & $3.78 \mathrm{E}-02$ & $3.70 \mathrm{E}-02$ & 3.59E-02 & 3.43E-02 & $3.22 \mathrm{E}-02$ & $2.98 \mathrm{E}-02$ & $2.70 \mathrm{E}-02$ & $2.41 \mathrm{E}-02$ & $2.15 \mathrm{E}-02$ \\
\hline ZR 92 & $2.84 \mathrm{E}-02$ & 3.00E-02 & 3.26E-02 & 3.50E-02 & $3.71 \mathrm{E}-02$ & $3.86 \mathrm{E}-02$ & 3.98E-02 & $4.04 \mathrm{E}-02$ & $4.05 \mathrm{E}-02$ & 4.02E-02 & $3.94 \mathrm{E}-02$ & $3.81 \mathrm{E}-02$ & $3.64 \mathrm{E}-02$ & 3.42E-02 & 3.16E-02 & $2.86 \mathrm{E}-02$ & $2.54 \mathrm{E}-02$ & 2.27E-02 \\
\hline ZR 93 & 3.13E-02 & $3.30 \mathrm{E}-02$ & 3.58E-02 & 3.85E-02 & 4.07E-02 & 4.24E-02 & 4.36E-02 & 4.43E-02 & 4.45E-02 & 4.41E-02 & 4.33E- 02 & 4.19E-02 & 4.00E-02 & $3.76 \mathrm{E}-02$ & 3.47E-02 & $3.15 \mathrm{E}-02$ & $2.80 \mathrm{E}-02$ & $2.50 \mathrm{E}-02$ \\
\hline NB 93 & 1.22E- 07 & 1.29E- 07 & 1.40E-07 & 1.50E- 07 & 1.59E-07 & 1.66E-07 & 1.70E-07 & 1.73E-07 & 1.74E-07 & 1.72E- 07 & 1.69E- 07 & 1.63E- 07 & 1.56E- 07 & 1.46E-07 & 1.35E-07 & 1.22E- 07 & 1.09E- 07 & $9.68 \mathrm{E}-08$ \\
\hline NB 93M & $1.72 \mathrm{E}-07$ & $1.82 \mathrm{E}-07$ & $1.97 \mathrm{E}-07$ & 2.12E-07 & $2.24 \mathrm{E}-07$ & $2.34 \mathrm{E}-07$ & $2.41 \mathrm{E}-07$ & $2.44 \mathrm{E}-07$ & $2.45 \mathrm{E}-07$ & $2.43 \mathrm{E}-07$ & 2.39E-07 & $2.31 \mathrm{E}-07$ & $2.20 \mathrm{E}-07$ & $2.07 \mathrm{E}-07$ & $1.91 \mathrm{E}-07$ & $1.73 \mathrm{E}-07$ & $1.54 \mathrm{E}-07$ & 1.37E-07 \\
\hline
\end{tabular}

lxxxiii 


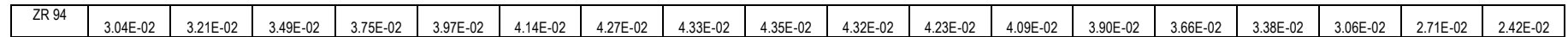
Position=Segment location (midpoint of 2-in. segment) from bottom of fuel (BOF); 2 in. of fuel $\sim 14.2 \mathrm{~g}$

lxxxiv 
Table A-2d. Composition (grams) in 2-inch fuel segment: ORIGEN calculation results for Pin193045, decayed to 3/11/2011.

\begin{tabular}{|c|c|c|c|c|c|c|c|c|c|c|c|c|c|c|c|c|c|c|}
\hline Position: & 1 & 3 & 5 & 7 & 9 & 11 & 13 & 15 & 17 & 19 & 21 & 23 & 25 & 27 & 29 & 31 & 33 & 35 \\
\hline ZR 95 & $3.83 \mathrm{E}-34$ & $4.01 \mathrm{E}-34$ & $4.30 \mathrm{E}-34$ & $4.57 \mathrm{E}-34$ & $4.79 \mathrm{E}-34$ & $4.96 \mathrm{E}-34$ & $5.08 \mathrm{E}-34$ & $5.14 \mathrm{E}-34$ & $5.17 \mathrm{E}-34$ & $5.14 \mathrm{E}-34$ & $5.06 \mathrm{E}-34$ & $4.94 \mathrm{E}-34$ & $4.76 \mathrm{E}-34$ & $4.53 \mathrm{E}-34$ & 4.24E-34 & $3.89 \mathrm{E}-34$ & $3.51 E-34$ & $3.17 \mathrm{E}-34$ \\
\hline NB 95 & $2.16 \mathrm{E}-34$ & $2.26 \mathrm{E}-34$ & $2.42 \mathrm{E}-34$ & $2.57 \mathrm{E}-34$ & $2.70 \mathrm{E}-34$ & $2.79 \mathrm{E}-34$ & $2.86 \mathrm{E}-34$ & $2.90 \mathrm{E}-34$ & $2.91 \mathrm{E}-34$ & $2.89 \mathrm{E}-34$ & $2.85 \mathrm{E}-34$ & $2.78 \mathrm{E}-34$ & $2.68 \mathrm{E}-34$ & $2.55 \mathrm{E}-34$ & $2.39 E-34$ & $2.19 \mathrm{E}-34$ & $1.98 \mathrm{E}-34$ & $1.79 \mathrm{E}-34$ \\
\hline NB 95M & $1.51 \mathrm{E}-37$ & $1.59 \mathrm{E}-37$ & $1.70 \mathrm{E}-37$ & $1.81 \mathrm{E}-37$ & $1.89 \mathrm{E}-37$ & $1.96 \mathrm{E}-37$ & $2.01 E-37$ & $2.03 \mathrm{E}-37$ & $2.04 E-37$ & $2.03 \mathrm{E}-37$ & $2.00 \mathrm{E}-37$ & $1.95 \mathrm{E}-37$ & $1.88 \mathrm{E}-37$ & $1.79 E-37$ & $1.67 \mathrm{E}-37$ & $1.54 \mathrm{E}-37$ & 1.39E-37 & $1.25 \mathrm{E}-37$ \\
\hline MO 95 & $3.19 \mathrm{E}-02$ & $3.37 \mathrm{E}-02$ & $3.65 \mathrm{E}-02$ & $3.92 \mathrm{E}-02$ & $4.14 \mathrm{E}-02$ & $4.31 \mathrm{E}-02$ & $4.43 \mathrm{E}-02$ & $4.50 \mathrm{E}-02$ & $4.52 \mathrm{E}-02$ & $4.48 \mathrm{E}-02$ & $4.40 \mathrm{E}-02$ & $4.26 \mathrm{E}-02$ & $4.07 E-02$ & $3.83 \mathrm{E}-02$ & $3.54 \mathrm{E}-02$ & $3.21 \mathrm{E}-02$ & $2.86 \mathrm{E}-02$ & $2.56 \mathrm{E}-02$ \\
\hline ZR 96 & $3.20 \mathrm{E}-02$ & 3.39E-02 & $3.68 \mathrm{E}-02$ & $3.95 \mathrm{E}-02$ & $4.19 \mathrm{E}-02$ & $4.37 \mathrm{E}-02$ & $4.50 \mathrm{E}-02$ & $4.57 \mathrm{E}-02$ & $4.59 \mathrm{E}-02$ & $4.55 \mathrm{E}-02$ & $4.46 \mathrm{E}-02$ & $4.31 \mathrm{E}-02$ & $4.11 \mathrm{E}-02$ & $3.86 \mathrm{E}-02$ & $3.56 \mathrm{E}-02$ & $3.22 E-02$ & $2.86 \mathrm{E}-02$ & $2.55 \mathrm{E}-02$ \\
\hline MO 96 & $5.71 \mathrm{E}-04$ & $7.00 \mathrm{E}-04$ & $8.59 \mathrm{E}-04$ & $1.02 \mathrm{E}-03$ & $1.16 \mathrm{E}-03$ & $1.28 \mathrm{E}-03$ & $1.37 \mathrm{E}-03$ & $1.42 \mathrm{E}-03$ & $1.43 \mathrm{E}-03$ & $1.40 \mathrm{E}-03$ & $1.34 \mathrm{E}-03$ & $1.24 \mathrm{E}-03$ & $1.12 \mathrm{E}-03$ & $9.71 \mathrm{E}-04$ & $8.12 \mathrm{E}-04$ & $6.48 \mathrm{E}-04$ & $4.91 \mathrm{E}-04$ & 3.58E-04 \\
\hline MO 97 & $3.08 \mathrm{E}-02$ & $3.26 \mathrm{E}-02$ & $3.53 \mathrm{E}-02$ & $3.79 \mathrm{E}-02$ & 4.01E-02 & $4.18 \mathrm{E}-02$ & $4.30 \mathrm{E}-02$ & 4.37E-02 & $4.38 \mathrm{E}-02$ & $4.35 \mathrm{E}-02$ & $4.26 \mathrm{E}-02$ & 4.13E-02 & $3.94 \mathrm{E}-02$ & $3.70 \mathrm{E}-02$ & $3.42 E-02$ & $3.10 \mathrm{E}-02$ & $2.76 \mathrm{E}-02$ & $2.46 \mathrm{E}-02$ \\
\hline MO 98 & $3.20 \mathrm{E}-02$ & $3.40 \mathrm{E}-02$ & $3.71 \mathrm{E}-02$ & $4.00 \mathrm{E}-02$ & $4.24 \mathrm{E}-02$ & $4.43 \mathrm{E}-02$ & $.57 \mathrm{E}-02$ & $4.64 \mathrm{E}-02$ & $4.66 \mathrm{E}-02$ & $4.62 \mathrm{E}-02$ & $4.53 \mathrm{E}-02$ & $4.37 \mathrm{E}-02$ & $4.16 \mathrm{E}-02$ & $3.90 \mathrm{E}-02$ & $3.59 \mathrm{E}-02$ & $3.24 \mathrm{E}-02$ & $2.87 \mathrm{E}-02$ & $2.54 \mathrm{E}-02$ \\
\hline TC 98 & $8.98 \mathrm{E}-07$ & $1.10 \mathrm{E}-06$ & $1.36 \mathrm{E}-06$ & $1.61 \mathrm{E}-06$ & $1.83 \mathrm{E}-06$ & $2.02 \mathrm{E}-06$ & $16 \mathrm{E}-06$ & $2.24 \mathrm{E}-06$ & $2.26 \mathrm{E}-06$ & $2.22 \mathrm{E}-06$ & $2.12 E-06$ & $1.97 \mathrm{E}-06$ & $1.77 \mathrm{E}-06$ & $1.54 \mathrm{E}-06$ & $1.28 \mathrm{E}-06$ & $1.02 E-06$ & $7.73 \mathrm{E}-07$ & $5.62 \mathrm{E}-07$ \\
\hline TC 99 & $3.04 \mathrm{E}-02$ & 3.22E-02 & 3.49E-02 & 3.74E-02 & 3.96E-02 & $4.12 \mathrm{E}-02$ & $4.24 \mathrm{E}-02$ & $4.31 \mathrm{E}-02$ & 4.32E-02 & 4.29E-02 & 4.21E-02 & 4.07E-02 & $3.89 \mathrm{E}-02$ & 3.66E-02 & 3.38E-02 & 3.07E-02 & $2.73 \mathrm{E}-02$ & $2.43 \mathrm{E}-02$ \\
\hline RU 99 & $2.05 \mathrm{E}-06$ & $2.17 \mathrm{E}-06$ & $2.35 \mathrm{E}-06$ & $2.52 \mathrm{E}-06$ & $2.67 \mathrm{E}-06$ & $2.78 \mathrm{E}-06$ & $2.86 \mathrm{E}-06$ & $2.90 \mathrm{E}-06$ & $2.91 \mathrm{E}-06$ & $2.89 \mathrm{E}-06$ & $2.83 \mathrm{E}-06$ & $2.74 \mathrm{E}-06$ & $2.62 E-06$ & $2.46 \mathrm{E}-06$ & $2.28 \mathrm{E}-06$ & $2.06 \mathrm{E}-06$ & 1.83E-06 & $1.64 \mathrm{E}-06$ \\
\hline M0100 & $3.42 \mathrm{E}-02$ & 3.62E-02 & $3.94 \mathrm{E}-02$ & 24E-02 & $4.49 \mathrm{E}-02$ & $4.69 \mathrm{E}-02$ & $82 \mathrm{E}-02$ & $4.90 \mathrm{E}-02$ & $4.92 \mathrm{E}-02$ & $4.88 \mathrm{E}-02$ & $4.78 \mathrm{E}-02$ & $4.62 \mathrm{E}-02$ & $4.41 \mathrm{E}-02$ & $4.14 \mathrm{E}-02$ & $3.82 E-02$ & $3.45 \mathrm{E}-02$ & $3.06 \mathrm{E}-02$ & $2.72 \mathrm{E}-02$ \\
\hline RU100 & $9.87 \mathrm{E}-04$ & $1.21 \mathrm{E}-03$ & 1.49E-03 & $1.76 \mathrm{E}-03$ & $2.01 \mathrm{E}-03$ & $2.21 \mathrm{E}-03$ & $36 \mathrm{E}-03$ & $\mathrm{E}-03$ & $2.47 \mathrm{E}-03$ & $2.43 \mathrm{E}-03$ & $2.32 \mathrm{E}-03$ & $2.15 \mathrm{E}-03$ & $1.94 \mathrm{E}-03$ & $1.68 \mathrm{E}-03$ & $1.41 \mathrm{E}-03$ & $1.12 \mathrm{E}-03$ & $8.51 \mathrm{E}-04$ & $6.19 \mathrm{E}-04$ \\
\hline RU101 & $2.95 \mathrm{E}-02$ & 3.12E-02 & $3.39 \mathrm{E}-02$ & 3.64E-02 & 3.84E-02 & $4.01 \mathrm{E}-02$ & 4.12E-02 & 4.18E-02 & 4.20E-02 & 4.17E-02 & $4.09 \mathrm{E}-02$ & $3.96 \mathrm{E}-02$ & $3.78 \mathrm{E}-02$ & 3.55E-02 & 3.29E-02 & $2.98 \mathrm{E}-02$ & $2.64 \mathrm{E}-02$ & $2.36 \mathrm{E}-02$ \\
\hline RU10 & $2.73 \mathrm{E}-02$ & 2.93E-02 & $3.21 \mathrm{E}-02$ & $3.47 \mathrm{E}-02$ & $3.70 \mathrm{E}-02$ & $3.88 \mathrm{E}-02$ & $4.00 \mathrm{E}-02$ & 4.07E-02 & 4.09E-02 & 4.05E-02 & $3.96 \mathrm{E}-02$ & $3.82 \mathrm{E}-02$ & 3.63E-02 & 3.39E-02 & $3.11 \mathrm{E}-02$ & $2.79 \mathrm{E}-02$ & $2.45 \mathrm{E}-02$ & 2.15E-02 \\
\hline RH102 & $1.67 \mathrm{E}-09$ & 2.07E-09 & $2.55 \mathrm{E}-09$ & 3.02E-09 & 3.45E-09 & $3.81 \mathrm{E}-09$ & 4.07E-09 & 4.22E-09 & 4.26E-09 & 4.19E-09 & $4.00 \mathrm{E}-09$ & $3.71 \mathrm{E}-09$ & 3.33E-09 & 2.89E-09 & 2.41E-09 & $1.92 \mathrm{E}-09$ & $1.45 \mathrm{E}-09$ & $1.04 \mathrm{E}-09$ \\
\hline RU103 & $0.00 E+00$ & $0.00 \mathrm{E}+00$ & $0.00 E+00$ & $0.00 E+00$ & $0.00 \mathrm{E}+00$ & $0.00 \mathrm{E}+00$ & $0.00 \mathrm{E}+00$ & $0.00 \mathrm{E}+00$ & $0.00 \mathrm{E}+00$ & $0.00 E+00$ & $0.00 \mathrm{E}+00$ & $0.00 \mathrm{E}+00$ & $0.00 E+00$ & $0.00 \mathrm{E}+00$ & $0.00 E+00$ & $0.00 \mathrm{E}+00$ & $0.00 \mathrm{E}+00$ & $0.00 \mathrm{E}+00$ \\
\hline RH103 & $1.95 \mathrm{E}-02$ & $2.08 \mathrm{E}-02$ & $2.27 \mathrm{E}-02$ & 2.44E-02 & $2.59 \mathrm{E}-02$ & $2.70 \mathrm{E}-02$ & $2.78 \mathrm{E}-02$ & $2.83 \mathrm{E}-02$ & 2.84E-02 & 2.82E-02 & $2.76 \mathrm{E}-02$ & $2.67 \mathrm{E}-02$ & 2.54E-02 & $2.39 \mathrm{E}-02$ & $2.20 \mathrm{E}-02$ & $1.98 \mathrm{E}-02$ & 1.76E-02 & $1.55 \mathrm{E}-02$ \\
\hline RH103M & $0.00 \mathrm{E}+00$ & $0.00 \mathrm{E}+00$ & $0.00 E+00$ & $0.00 E+00$ & $0.00 \mathrm{E}+00$ & $0.00 \mathrm{E}+00$ & $0.00 \mathrm{E}+00$ & $0.00 \mathrm{E}+00$ & $0.00 \mathrm{E}+00$ & $0.00 \mathrm{E}+00$ & $0.00 \mathrm{E}+00$ & $0.00 \mathrm{E}+00$ & $0.00 \mathrm{E}+00$ & $0.00 \mathrm{E}+00$ & $0.00 \mathrm{E}+00$ & $0.00 E+00$ & $0.00 \mathrm{E}+00$ & $0.00 \mathrm{E}+00$ \\
\hline RU104 & $1.49 \mathrm{E}-02$ & $1.60 \mathrm{E}-02$ & $1.76 \mathrm{E}-02$ & $1.91 \mathrm{E}-02$ & $2.04 \mathrm{E}-02$ & $2.14 \mathrm{E}-02$ & $2.21 \mathrm{E}-02$ & $2.25 \mathrm{E}-02$ & $2.26 \mathrm{E}-02$ & $2.24 \mathrm{E}-02$ & $2.19 \mathrm{E}-02$ & $2.11 \mathrm{E}-02$ & $2.00 \mathrm{E}-02$ & $1.86 \mathrm{E}-02$ & $1.71 \mathrm{E}-02$ & $1.53 \mathrm{E}-02$ & $1.34 \mathrm{E}-02$ & $1.17 \mathrm{E}-02$ \\
\hline PD104 & $9.96 \mathrm{E}-04$ & $1.23 \mathrm{E}-03$ & $1.52 \mathrm{E}-03$ & $1.80 \mathrm{E}-03$ & $2.05 E-03$ & $2.26 \mathrm{E}-03$ & $2.42 \mathrm{E}-03$ & $2.51 \mathrm{E}-03$ & $2.53 \mathrm{E}-03$ & $2.49 \mathrm{E}-03$ & $2.37 \mathrm{E}-03$ & $2.20 \mathrm{E}-03$ & $1.98 \mathrm{E}-03$ & $1.72 \mathrm{E}-03$ & $1.43 \mathrm{E}-03$ & $1.14 \mathrm{E}-03$ & $8.63 \mathrm{E}-04$ & $6.23 \mathrm{E}-04$ \\
\hline
\end{tabular}

$\operatorname{lxxxv}$ 


\begin{tabular}{|c|c|c|c|c|c|c|c|c|c|c|c|c|c|c|c|c|c|c|}
\hline PD105 & & & & & & & & & & & & & & & & & & \\
\hline & $\begin{array}{r}8.40 \mathrm{E}-03 \\
\end{array}$ & $9.11 \mathrm{E}-03$ & $1.00 \mathrm{E}-02$ & $1.09 \mathrm{E}-02$ & $1.16 \mathrm{E}-02$ & $1.22 \mathrm{E}-02$ & $1.26 \mathrm{E}-02$ & $1.28 \mathrm{E}-02$ & $\begin{array}{r}1.28 \mathrm{E}-02 \\
\end{array}$ & $\begin{array}{l}1.27 \mathrm{E}-02 \\
\end{array}$ & $1.24 \mathrm{E}-02$ & $\begin{array}{l}1.20 \mathrm{E}-02 \\
\end{array}$ & $1.14 \mathrm{E}-02$ & $1.06 \mathrm{E}-02$ & $9.71 \mathrm{E}-03$ & $8.69 \mathrm{E}-03$ & $7.60 \mathrm{E}-03$ & $\begin{array}{l}6.59 \mathrm{E}-03 \\
\end{array}$ \\
\hline RU1C & $464 \mathrm{E}-09$ & $508 \mathrm{E}-09$ & $5.67 \mathrm{E}-09$ & $6.22 \mathrm{E}-09$ & $6.70 \mathrm{E}-09$ & $709 E-09$ & $736 \mathrm{E}-09$ & $752 \mathrm{E}-09$ & $756 \mathrm{E}-09$ & $749 E-09$ & $729 E-09$ & $6.99 E-09$ & $658 \mathrm{E}-09$ & $6.07 E-09$ & 5.49E-09 & $485 E-09$ & 4.17E-09 & $3.56 \mathrm{E}-09$ \\
\hline
\end{tabular}

Position=Segment location (midpoint of 2-in. segment) from bottom of fuel (BOF); $2 \mathrm{in.}$ of fuel $\sim 14.2 \mathrm{~g}$

lxxxvi 
Table A-2e. Composition (grams) in 2-inch fuel segment: ORIGEN calculation results for Pin 193045, decayed to 3/11/2011.

\begin{tabular}{|c|c|c|c|c|c|c|c|c|c|c|c|c|c|c|c|c|c|c|}
\hline Position: & 1 & 3 & 5 & 7 & 9 & 11 & 13 & 15 & 17 & 19 & 21 & 23 & 25 & 27 & 29 & 31 & 33 & 35 \\
\hline PD106 & $5.68 \mathrm{E}-03$ & $6.32 \mathrm{E}-03$ & $7.13 \mathrm{E}-03$ & $7.89 \mathrm{E}-03$ & $8.55 \mathrm{E}-03$ & $9.09 \mathrm{E}-03$ & $9.46 \mathrm{E}-03$ & $9.68 \mathrm{E}-03$ & $9.74 \mathrm{E}-03$ & 9.63E-03 & $9.35 \mathrm{E}-03$ & $8.92 \mathrm{E}-03$ & $8.35 \mathrm{E}-03$ & 7.66E-03 & $6.86 \mathrm{E}-03$ & $6.00 \mathrm{E}-03$ & $5.10 \mathrm{E}-03$ & 4.29E-03 \\
\hline PD107 & $3.39 \mathrm{E}-03$ & $3.70 \mathrm{E}-03$ & $4.11 \mathrm{E}-03$ & $4.50 \mathrm{E}-03$ & $4.84 \mathrm{E}-03$ & $5.10 \mathrm{E}-03$ & $5.29 \mathrm{E}-03$ & $5.40 \mathrm{E}-03$ & $5.42 \mathrm{E}-03$ & $5.37 \mathrm{E}-03$ & $5.23 \mathrm{E}-03$ & $5.02 \mathrm{E}-03$ & $4.73 \mathrm{E}-03$ & $4.38 \mathrm{E}-03$ & $3.97 \mathrm{E}-03$ & $3.51 \mathrm{E}-03$ & $3.03 \mathrm{E}-03$ & $2.60 \mathrm{E}-03$ \\
\hline AG107 & $7.43 \mathrm{E}-09$ & 8.11E-09 & $9.01 \mathrm{E}-09$ & $9.86 \mathrm{E}-09$ & $1.06 \mathrm{E}-08$ & $1.12 \mathrm{E}-08$ & 1.16E-08 & $1.18 \mathrm{E}-08$ & 1.19E-08 & 1.18E-08 & 1.15E-08 & 1.10E-08 & $1.04 \mathrm{E}-08$ & $9.59 \mathrm{E}-09$ & $8.69 \mathrm{E}-09$ & $7.70 \mathrm{E}-09$ & $6.65 \mathrm{E}-09$ & $5.71 \mathrm{E}-09$ \\
\hline PD108 & $2.34 \mathrm{E}-03$ & 2.59E-03 & $2.91 \mathrm{E}-03$ & $3.22 \mathrm{E}-03$ & $3.48 \mathrm{E}-03$ & $3.70 \mathrm{E}-03$ & $3.85 \mathrm{E}-03$ & $3.94 \mathrm{E}-03$ & $3.96 \mathrm{E}-03$ & $3.92 \mathrm{E}-03$ & $3.81 \mathrm{E}-03$ & $3.63 \mathrm{E}-03$ & $3.40 \mathrm{E}-03$ & $3.12 \mathrm{E}-03$ & $2.80 \mathrm{E}-03$ & $2.45 \mathrm{E}-03$ & $2.09 \mathrm{E}-03$ & $1.76 \mathrm{E}-03$ \\
\hline CD108 & 3.49E-08 & 4.43E-08 & 5.57E- 08 & $6.71 \mathrm{E}-08$ & $7.76 \mathrm{E}-08$ & $8.63 \mathrm{E}-08$ & $9.28 \mathrm{E}-08$ & $9.66 \mathrm{E}-08$ & $9.76 \mathrm{E}-08$ & $9.57 \mathrm{E}-08$ & $9.09 \mathrm{E}-08$ & 8.37E-08 & $7.45 \mathrm{E}-08$ & $6.38 \mathrm{E}-08$ & $5.25 \mathrm{E}-08$ & 4.11E-08 & $3.03 E-08$ & 2.12E-08 \\
\hline AG109 & $1.59 \mathrm{E}-03$ & $1.74 \mathrm{E}-03$ & $1.94 \mathrm{E}-03$ & $2.13 \mathrm{E}-03$ & $2.30 \mathrm{E}-03$ & $2.43 \mathrm{E}-03$ & $2.52 \mathrm{E}-03$ & $2.58 \mathrm{E}-03$ & $2.59 \mathrm{E}-03$ & $2.56 \mathrm{E}-03$ & $2.50 \mathrm{E}-03$ & $2.39 \mathrm{E}-03$ & $2.25 \mathrm{E}-03$ & $2.07 \mathrm{E}-03$ & $1.87 \mathrm{E}-03$ & $1.65 \mathrm{E}-03$ & 1.42E-03 & $1.21 \mathrm{E}-03$ \\
\hline PD110 & $1.09 \mathrm{E}-03$ & $1.20 \mathrm{E}-03$ & $1.33 \mathrm{E}-03$ & $1.46 \mathrm{E}-03$ & $1.56 \mathrm{E}-03$ & $1.64 \mathrm{E}-03$ & $1.70 \mathrm{E}-03$ & $1.73 \mathrm{E}-03$ & $1.74 \mathrm{E}-03$ & 1.72E- 03 & 1.68E-03 & 1.62E-03 & $1.53 \mathrm{E}-03$ & $1.42 \mathrm{E}-03$ & $1.29 \mathrm{E}-03$ & 1.15E-03 & $9.95 \mathrm{E}-04$ & $8.51 \mathrm{E}-04$ \\
\hline AG110M & $2.39 \mathrm{E}-14$ & $3.04 \mathrm{E}-14$ & $3.81 \mathrm{E}-14$ & $4.60 \mathrm{E}-14$ & $5.32 \mathrm{E}-14$ & $5.93 \mathrm{E}-14$ & $6.38 \mathrm{E}-14$ & $6.65 \mathrm{E}-14$ & $6.72 \mathrm{E}-14$ & $6.59 \mathrm{E}-14$ & $6.26 \mathrm{E}-14$ & $5.77 \mathrm{E}-14$ & $5.13 \mathrm{E}-14$ & 4.39E- 14 & $3.61 \mathrm{E}-14$ & $2.82 \mathrm{E}-14$ & $2.08 \mathrm{E}-14$ & $1.46 \mathrm{E}-14$ \\
\hline CD110 & $6.21 \mathrm{E}-05$ & $7.88 \mathrm{E}-05$ & $9.90 \mathrm{E}-05$ & 1.19E-04 & $1.38 \mathrm{E}-04$ & $1.53 \mathrm{E}-04$ & $1.65 \mathrm{E}-04$ & $1.72 \mathrm{E}-04$ & $1.73 \mathrm{E}-04$ & $1.70 \mathrm{E}-04$ & 1.62E-04 & 1.49E-04 & 1.32E-04 & 1.13E-04 & 9.32E- 05 & 7.30E-05 & $5.39 \mathrm{E}-05$ & $3.77 \mathrm{E}-05$ \\
\hline AG111 & $0.00 \mathrm{E}+00$ & $0.00 \mathrm{E}+00$ & $0.00 \mathrm{E}+00$ & $0.00 \mathrm{E}+00$ & $0.00 \mathrm{E}+00$ & $0.00 \mathrm{E}+00$ & $0.00 \mathrm{E}+00$ & $0.00 \mathrm{E}+00$ & $0.00 \mathrm{E}+00$ & $0.00 \mathrm{E}+00$ & $0.00 \mathrm{E}+00$ & $0.00 \mathrm{E}+00$ & $0.00 \mathrm{E}+00$ & $0.00 \mathrm{E}+00$ & $0.00 \mathrm{E}+00$ & $0.00 \mathrm{E}+00$ & $0.00 \mathrm{E}+00$ & $0.00 \mathrm{E}+00$ \\
\hline CD111 & $8.67 \mathrm{E}-04$ & $9.56 \mathrm{E}-04$ & $1.06 \mathrm{E}-03$ & 1.15E-03 & $1.23 \mathrm{E}-03$ & $1.29 \mathrm{E}-03$ & $1.33 \mathrm{E}-03$ & $1.35 \mathrm{E}-03$ & $1.36 \mathrm{E}-03$ & $1.35 \mathrm{E}-03$ & $1.32 \mathrm{E}-03$ & $1.27 \mathrm{E}-03$ & $1.20 \mathrm{E}-03$ & $1.12 \mathrm{E}-03$ & $1.03 \mathrm{E}-03$ & $9.19 \mathrm{E}-04$ & $7.99 \mathrm{E}-04$ & $6.83 \mathrm{E}-04$ \\
\hline CD112 & $7.69 \mathrm{E}-04$ & $8.53 \mathrm{E}-04$ & $9.45 \mathrm{E}-04$ & $1.03 \mathrm{E}-03$ & 1.10E-03 & $1.15 \mathrm{E}-03$ & $1.19 \mathrm{E}-03$ & $1.21 \mathrm{E}-03$ & 1.22E-03 & 1.20E-03 & 1.18E-03 & 1.13E-03 & $1.08 \mathrm{E}-03$ & $1.00 \mathrm{E}-03$ & $9.19 \mathrm{E}-04$ & $8.21 \mathrm{E}-04$ & $7.14 \mathrm{E}-04$ & $6.07 \mathrm{E}-04$ \\
\hline CD113 & $7.19 \mathrm{E}-04$ & $7.92 \mathrm{E}-04$ & $8.73 \mathrm{E}-04$ & $9.45 \mathrm{E}-04$ & $1.01 \mathrm{E}-03$ & $1.05 \mathrm{E}-03$ & $1.08 \mathrm{E}-03$ & $1.10 \mathrm{E}-03$ & $1.11 \mathrm{E}-03$ & 1.10E-03 & 1.07E-03 & $1.04 \mathrm{E}-03$ & $9.87 \mathrm{E}-04$ & $9.25 \mathrm{E}-04$ & $8.50 \mathrm{E}-04$ & $7.64 \mathrm{E}-04$ & $6.68 \mathrm{E}-04$ & $5.73 \mathrm{E}-04$ \\
\hline CD113M & $4.92 \mathrm{E}-06$ & $5.50 \mathrm{E}-06$ & $6.16 \mathrm{E}-06$ & $6.74 \mathrm{E}-06$ & $7.25 \mathrm{E}-06$ & $7.64 \mathrm{E}-06$ & $7.91 \mathrm{E}-06$ & $8.07 \mathrm{E}-06$ & $8.11 \mathrm{E}-06$ & $8.03 \mathrm{E}-06$ & $7.83 \mathrm{E}-06$ & $7.52 \mathrm{E}-06$ & $7.10 \mathrm{E}-06$ & $6.58 \mathrm{E}-06$ & $5.97 \mathrm{E}-06$ & $5.30 \mathrm{E}-06$ & 4.56E- 06 & $3.85 \mathrm{E}-06$ \\
\hline IN11 & $8.14 \mathrm{E}-06$ & 9.09E-06 & $1.02 \mathrm{E}-05$ & 1.11E-05 & 1.19E-05 & 1.26E-05 & $1.30 \mathrm{E}-05$ & $1.33 \mathrm{E}-05$ & $1.34 \mathrm{E}-05$ & 1.32E-05 & 1.29E-05 & 1.24E-05 & 1.17E- 05 & 1.09E-05 & $9.85 E-06$ & $8.74 \mathrm{E}-06$ & $7.53 \mathrm{E}-06$ & $6.36 \mathrm{E}-06$ \\
\hline CD114 & $6.87 \mathrm{E}-04$ & 7.54E-04 & $8.30 \mathrm{E}-04$ & $8.98 \mathrm{E}-04$ & 9.55E-04 & 9.99E-04 & $1.03 \mathrm{E}-03$ & $1.05 \mathrm{E}-03$ & $1.05 \mathrm{E}-03$ & $1.04 \mathrm{E}-03$ & $1.02 \mathrm{E}-03$ & $9.86 \mathrm{E}-04$ & 9.39E-04 & $8.79 \mathrm{E}-04$ & 8.07E-04 & $7.26 \mathrm{E}-04$ & $6.35 \mathrm{E}-04$ & 5.47E-04 \\
\hline SN114 & 4.11E-08 & $5.27 \mathrm{E}-08$ & $6.60 \mathrm{E}-08$ & $7.90 \mathrm{E}-08$ & $9.08 \mathrm{E}-08$ & $1.01 \mathrm{E}-07$ & $1.08 \mathrm{E}-07$ & 1.12E-07 & 1.13E-07 & 1.11E-07 & $1.06 \mathrm{E}-07$ & $9.76 \mathrm{E}-08$ & $8.74 \mathrm{E}-08$ & $7.54 \mathrm{E}-08$ & $6.25 \mathrm{E}-08$ & 4.93E-08 & 3.66E-08 & $2.55 \mathrm{E}-08$ \\
\hline CD115M & $0.00 \mathrm{E}+00$ & $0.00 \mathrm{E}+00$ & $0.00 \mathrm{E}+00$ & $0.00 \mathrm{E}+00$ & $0.00 \mathrm{E}+00$ & $0.00 \mathrm{E}+00$ & $0.00 \mathrm{E}+00$ & $0.00 \mathrm{E}+00$ & $0.00 \mathrm{E}+00$ & $0.00 \mathrm{E}+00$ & $0.00 \mathrm{E}+00$ & $0.00 \mathrm{E}+00$ & $0.00 \mathrm{E}+00$ & $0.00 \mathrm{E}+00$ & $0.00 \mathrm{E}+00$ & $0.00 \mathrm{E}+00$ & $0.00 \mathrm{E}+00$ & $0.00 \mathrm{E}+00$ \\
\hline $\mathbb{I N} 115$ & $5.12 \mathrm{E}-04$ & $5.43 \mathrm{E}-04$ & $5.76 \mathrm{E}-04$ & $6.02 \mathrm{E}-04$ & $6.22 \mathrm{E}-04$ & $6.37 \mathrm{E}-04$ & $6.46 \mathrm{E}-04$ & $6.51 \mathrm{E}-04$ & $6.52 \mathrm{E}-04$ & $6.49 \mathrm{E}-04$ & $6.43 \mathrm{E}-04$ & $6.32 \mathrm{E}-04$ & $6.16 \mathrm{E}-04$ & $5.94 \mathrm{E}-04$ & $5.65 \mathrm{E}-04$ & $5.29 \mathrm{E}-04$ & $4.83 \mathrm{E}-04$ & 4.33E-04 \\
\hline SN115 & $2.41 \mathrm{E}-05$ & 2.67E-05 & $2.95 \mathrm{E}-05$ & $3.20 \mathrm{E}-05$ & $3.41 \mathrm{E}-05$ & 3.57E-05 & $3.68 \mathrm{E}-05$ & $3.74 \mathrm{E}-05$ & $3.76 \mathrm{E}-05$ & $3.73 \mathrm{E}-05$ & $3.65 \mathrm{E}-05$ & $3.52 \mathrm{E}-05$ & 3.35E-05 & 3.13E-05 & 2.87E-05 & $2.58 \mathrm{E}-05$ & 2.25E-05 & $1.92 \mathrm{E}-05$ \\
\hline CD116 & $6.71 \mathrm{E}-04$ & 7.33E-04 & $8.04 \mathrm{E}-04$ & $8.67 \mathrm{E}-04$ & $9.20 \mathrm{E}-04$ & $9.60 \mathrm{E}-04$ & $9.88 \mathrm{E}-04$ & $1.00 \mathrm{E}-03$ & $1.01 \mathrm{E}-03$ & $9.99 \mathrm{E}-04$ & $9.79 \mathrm{E}-04$ & $9.47 \mathrm{E}-04$ & $9.04 \mathrm{E}-04$ & $8.49 \mathrm{E}-04$ & $7.82 \mathrm{E}-04$ & $7.06 \mathrm{E}-04$ & $6.21 \mathrm{E}-04$ & 5.37E-04 \\
\hline
\end{tabular}

1xxxvii 


\begin{tabular}{|c|c|c|c|c|c|c|c|c|c|c|c|c|c|c|c|c|c|c|}
\hline SN116 & $1.81 \mathrm{E}-04$ & 2.25E-04 & 2.73E-04 & $3.19 \mathrm{E}-04$ & $3.58 \mathrm{E}-04$ & $3.90 \mathrm{E}-04$ & 4.13E-04 & 4.26E-04 & $4.30 \mathrm{E}-04$ & 4.23E-04 & 4.06E-04 & 3.81E-04 & 3.47E-04 & 3.07E-04 & $2.61 \mathrm{E}-04$ & $2.12 \mathrm{E}-04$ & 1.63E-04 & 1.18E-04 \\
\hline SN117 & $6.69 \mathrm{E}-04$ & $7.32 \mathrm{E}-04$ & $8.04 \mathrm{E}-04$ & $8.68 \mathrm{E}-04$ & $9.21 \mathrm{E}-04$ & $9.62 \mathrm{E}-04$ & $9.90 \mathrm{E}-04$ & $1.01 \mathrm{E}-03$ & $1.01 \mathrm{E}-03$ & $1.00 \mathrm{E}-03$ & $9.82 E-04$ & $9.49 \mathrm{E}-04$ & $9.06 \mathrm{E}-04$ & $8.50 \mathrm{E}-04$ & $7.83 \mathrm{E}-04$ & $7.06 \mathrm{E}-04$ & $6.19 \mathrm{E}-04$ & $5.35 \mathrm{E}-04$ \\
\hline SN118 & $6.97 \mathrm{E}-04$ & $7.62 \mathrm{E}-04$ & $8.37 \mathrm{E}-04$ & $9.04 \mathrm{E}-04$ & $9.60 \mathrm{E}-04$ & $1.00 \mathrm{E}-03$ & $1.03 \mathrm{E}-03$ & $1.05 \mathrm{E}-03$ & $1.05 \mathrm{E}-03$ & $1.05 \mathrm{E}-03$ & $1.02 \mathrm{E}-03$ & $9.90 \mathrm{E}-04$ & $9.43 \mathrm{E}-04$ & $8.85 \mathrm{E}-04$ & $8.14 \mathrm{E}-04$ & 7.33E-04 & $6.44 \mathrm{E}-04$ & $5.57 \mathrm{E}-04$ \\
\hline SN119 & $6.93 \mathrm{E}-04$ & 7.57E-04 & $8.32 \mathrm{E}-04$ & $8.99 \mathrm{E}-04$ & $9.55 \mathrm{E}-04$ & $9.98 \mathrm{E}-04$ & $1.03 \mathrm{E}-03$ & $1.04 \mathrm{E}-03$ & $1.05 \mathrm{E}-03$ & $1.04 \mathrm{E}-03$ & $1.02 \mathrm{E}-03$ & $9.84 \mathrm{E}-04$ & $9.38 \mathrm{E}-04$ & $8.80 \mathrm{E}-04$ & $8.09 \mathrm{E}-04$ & $7.29 \mathrm{E}-04$ & $6.40 \mathrm{E}-04$ & $5.53 \mathrm{E}-04$ \\
\hline
\end{tabular}


Table A-2f. Composition (grams) in 2-inch fuel segment: ORIGEN calculation results for Pin193045, decayed to 3/11/2011.

\begin{tabular}{|c|c|c|c|c|c|c|c|c|c|c|c|c|c|c|c|c|c|c|}
\hline Position: & 1 & 3 & 5 & 7 & 9 & 11 & 13 & 15 & 17 & 19 & 21 & 23 & 25 & 27 & 29 & 31 & 33 & 35 \\
\hline SN119M & $9.15 \mathrm{E}-15$ & $1.01 \mathrm{E}-14$ & 1.11E-14 & 1.21E-14 & 1.29E-14 & $1.35 \mathrm{E}-14$ & 1.39E-14 & 1.42E-14 & 1.42E-14 & 1.41E-14 & 1.38E-14 & 1.33E-14 & 1.27E-14 & 1.19E-14 & 1.09E-14 & $9.78 E-15$ & $8.54 \mathrm{E}-15$ & $7.35 \mathrm{E}-15$ \\
\hline SN120 & $7.09 \mathrm{E}-04$ & $7.74 \mathrm{E}-04$ & $8.50 \mathrm{E}-04$ & $9.18 \mathrm{E}-04$ & $9.74 \mathrm{E}-04$ & $1.02 \mathrm{E}-03$ & $1.05 \mathrm{E}-03$ & $1.06 \mathrm{E}-03$ & 1.07E-03 & $1.06 \mathrm{E}-03$ & $1.04 \mathrm{E}-03$ & $1.00 \mathrm{E}-03$ & $9.58 \mathrm{E}-04$ & $8.98 \mathrm{E}-04$ & $8.27 \mathrm{E}-04$ & $7.46 \mathrm{E}-04$ & $6.55 \mathrm{E}-04$ & $5.67 \mathrm{E}-04$ \\
\hline SN121M & $2.33 \mathrm{E}-07$ & $2.46 \mathrm{E}-07$ & $2.68 \mathrm{E}-07$ & $2.91 \mathrm{E}-07$ & $3.10 \mathrm{E}-07$ & $3.25 \mathrm{E}-07$ & 3.36E-07 & $3.43 \mathrm{E}-07$ & $3.44 \mathrm{E}-07$ & $3.41 \mathrm{E}-07$ & $3.33 \mathrm{E}-07$ & $3.21 \mathrm{E}-07$ & $3.04 \mathrm{E}-07$ & $2.83 \mathrm{E}-07$ & $2.59 \mathrm{E}-07$ & 2.32E -07 & $2.04 \mathrm{E}-07$ & 1.82E-07 \\
\hline SB121 & $6.88 \mathrm{E}-04$ & $7.49 \mathrm{E}-04$ & $19 \mathrm{E}-04$ & $8.81 \mathrm{E}-04$ & $9.32 \mathrm{E}-04$ & $.71 \mathrm{E}-04$ & $9.97 \mathrm{E}-04$ & $1.01 \mathrm{E}-03$ & $1.02 \mathrm{E}-03$ & $1.01 \mathrm{E}-03$ & $9.89 \mathrm{E}-04$ & $9.58 \mathrm{E}-04$ & $9.16 \mathrm{E}-04$ & $8.63 \mathrm{E}-04$ & $7.97 \mathrm{E}-04$ & $7.22 \mathrm{E}-04$ & $6.37 \mathrm{E}-04$ & $5.53 \mathrm{E}-04$ \\
\hline SN122 & $7.70 \mathrm{E}-04$ & 8.41E-04 & $9.23 \mathrm{E}-04$ & 9.97E-04 & $1.06 \mathrm{E}-03$ & 1.11E-03 & $1.14 \mathrm{E}-03$ & 1.16E-03 & $1.16 \mathrm{E}-03$ & 1.15E- 03 & 1.13E-03 & $1.09 \mathrm{E}-03$ & $1.04 \mathrm{E}-03$ & $9.75 \mathrm{E}-04$ & $8.98 \mathrm{E}-04$ & $8.10 \mathrm{E}-04$ & $7.11 \mathrm{E}-04$ & $6.15 \mathrm{E}-04$ \\
\hline TE122 & $2.26 \mathrm{E}-05$ & $2.84 \mathrm{E}-05$ & 3.52E-05 & 4.17E-05 & $4.75 \mathrm{E}-05$ & 5.23E-05 & $5.57 \mathrm{E}-05$ & $5.78 \mathrm{E}-05$ & $5.83 \mathrm{E}-05$ & $5.73 \mathrm{E}-05$ & $5.47 \mathrm{E}-05$ & $5.08 \mathrm{E}-05$ & 4.58E-05 & 3.99E- 05 & 3.34E-05 & 2.66E-05 & $2.01 \mathrm{E}-05$ & 1.43E-05 \\
\hline SN123 & $1.90 \mathrm{E}-21$ & $2.06 \mathrm{E}-21$ & 2.23E-21 & $2.40 \mathrm{E}-21$ & $2.53 \mathrm{E}-21$ & 2.63E-21 & $2.70 \mathrm{E}-21$ & $2.74 \mathrm{E}-21$ & $2.75 \mathrm{E}-21$ & $2.74 \mathrm{E}-21$ & 2.69E-21 & 2.61E-21 & $2.51 \mathrm{E}-21$ & $2.37 \mathrm{E}-21$ & 2.20E-21 & 2.00E-21 & 1.78E-21 & $1.56 \mathrm{E}-21$ \\
\hline SB123 & $8.21 \mathrm{E}-04$ & $8.95 \mathrm{E}-04$ & $9.81 \mathrm{E}-04$ & $1.06 \mathrm{E}-03$ & 1.12E-03 & 1.17E-03 & $1.20 \mathrm{E}-03$ & 1.22E-03 & $1.23 \mathrm{E}-03$ & 1.22E-03 & 1.19E-03 & $1.15 \mathrm{E}-03$ & 1.10E-03 & $1.04 \mathrm{E}-03$ & $9.55 \mathrm{E}-04$ & $8.62 \mathrm{E}-04$ & $7.59 \mathrm{E}-04$ & $6.58 \mathrm{E}-04$ \\
\hline TE123 & 4.01E-07 & $5.84 \mathrm{E}-07$ & $8.15 \mathrm{E}-07$ & $1.06 \mathrm{E}-06$ & $1.30 \mathrm{E}-06$ & $1.51 \mathrm{E}-06$ & $1.67 \mathrm{E}-06$ & $1.77 \mathrm{E}-06$ & $1.79 \mathrm{E}-06$ & $1.74 \mathrm{E}-06$ & 1.63E-06 & $1.45 \mathrm{E}-06$ & 1.23E-06 & $9.94 \mathrm{E}-07$ & $7.54 \mathrm{E}-07$ & $5.32 \mathrm{E}-07$ & 3.43E- 07 & $2.00 \mathrm{E}-07$ \\
\hline TE123M & $0.00 \mathrm{E}+00$ & $7.20 \mathrm{E}-24$ & $0.00 \mathrm{E}+00$ & $0.00 \mathrm{E}+00$ & $0.00 \mathrm{E}+00$ & $0.00 \mathrm{E}+00$ & $0.00 E+00$ & $0.00 E+00$ & $0.00 E+00$ & $0.00 E+00$ & $0.00 \mathrm{E}+00$ & $0.00 \mathrm{E}+00$ & $0.00 \mathrm{E}+00$ & $0.00 \mathrm{E}+00$ & $0.00 \mathrm{E}+00$ & $6.61 \mathrm{E}-24$ & $0.00 E+00$ & $0.00 E+00$ \\
\hline SN124 & $9.88 \mathrm{E}-04$ & $1.08 \mathrm{E}-03$ & 1.18E-03 & $1.28 \mathrm{E}-03$ & $1.35 \mathrm{E}-03$ & $1.42 \mathrm{E}-03$ & $1.46 \mathrm{E}-03$ & $1.48 \mathrm{E}-03$ & $1.49 \mathrm{E}-03$ & 1.47E-03 & 1.44E- 03 & 1.40E-03 & 1.33E- 03 & $1.25 \mathrm{E}-03$ & 1.15E-03 & 1.04E-03 & $9.10 \mathrm{E}-04$ & $7.89 \mathrm{E}-04$ \\
\hline SB124 & $3.92 \mathrm{E}-39$ & $4.90 \mathrm{E}-39$ & $03 E-39$ & $7.12 \mathrm{E}-39$ & $8.10 \mathrm{E}-39$ & $8.91 \mathrm{E}-39$ & $9.49 \mathrm{E}-39$ & $9.83 \mathrm{E}-39$ & $9.93 \mathrm{E}-39$ & $9.77 \mathrm{E}-39$ & $9.36 \mathrm{E}-39$ & $8.71 E-39$ & $7.88 \mathrm{E}-39$ & $6.88 \mathrm{E}-39$ & $5.78 E-39$ & 4.64E-39 & 3.52E-39 & $2.53 \mathrm{E}-39$ \\
\hline TE124 & $1.52 \mathrm{E}-05$ & $1.90 \mathrm{E}-05$ & 2.34E-05 & $2.77 \mathrm{E}-05$ & 3.15E-05 & 3.46E-05 & $3.69 \mathrm{E}-05$ & 3.83E-05 & $3.86 \mathrm{E}-05$ & 3.79E-05 & 3.63E-05 & 3.37E-05 & $3.04 \mathrm{E}-05$ & $2.65 \mathrm{E}-05$ & 2.22E- 05 & 1.78E-05 & $1.35 \mathrm{E}-05$ & $9.71 \mathrm{E}-06$ \\
\hline SN125 & $0.00 \mathrm{E}+00$ & $0.00 \mathrm{E}+00$ & $0.00 \mathrm{E}+00$ & $0.00 \mathrm{E}+00$ & $0.00 \mathrm{E}+00$ & $0.00 \mathrm{E}+00$ & $0.00 \mathrm{E}+00$ & $0.00 \mathrm{E}+00$ & $0.00 \mathrm{E}+00$ & $0.00 \mathrm{E}+00$ & $0.00 \mathrm{E}+00$ & $0.00 \mathrm{E}+00$ & $0.00 \mathrm{E}+00$ & $0.00 \mathrm{E}+00$ & $0.00 \mathrm{E}+00$ & $0.00 \mathrm{E}+00$ & $0.00 \mathrm{E}+00$ & $0.00 \mathrm{E}+00$ \\
\hline SB12 & $6.85 \mathrm{E}-06$ & $7.45 \mathrm{E}-06$ & $8.16 \mathrm{E}-06$ & $8.79 \mathrm{E}-06$ & 9.32E-06 & $9.73 \mathrm{E}-06$ & $1.00 \mathrm{E}-05$ & $1.02 \mathrm{E}-05$ & 1.02E-05 & $1.01 \mathrm{E}-05$ & 9.93E-06 & $9.61 \mathrm{E}-06$ & 9.18E-06 & $8.62 \mathrm{E}-06$ & $7.95 E-06$ & $7.18 \mathrm{E}-06$ & $6.32 \mathrm{E}-06$ & $5.50 \mathrm{E}-06$ \\
\hline TE125 & 1.16E-03 & 1.27E- 03 & 1.39E-03 & 1.50E- 03 & 1.59E-03 & 1.66E-03 & $1.71 \mathrm{E}-03$ & 1.74E- 03 & 1.74E-03 & 1.73E-03 & $1.70 \mathrm{E}-03$ & 1.64E-03 & $1.56 \mathrm{E}-03$ & 1.47E-03 & $1.35 \mathrm{E}-03$ & 1.22E-03 & 1.07E-03 & $9.30 \mathrm{E}-04$ \\
\hline TE125M & $9.58 \mathrm{E}-08$ & 1.04 E- 07 & $1.14 \mathrm{E}-07$ & 1.23E-07 & $1.30 \mathrm{E}-07$ & $1.36 \mathrm{E}-07$ & $1.40 \mathrm{E}-07$ & 1.42E- 07 & 1.43E-07 & 1.42E-07 & $1.39 \mathrm{E}-07$ & $1.34 \mathrm{E}-07$ & 1.28E-07 & $1.21 \mathrm{E}-07$ & 1.11E-07 & 1.00E-07 & $8.85 \mathrm{E}-08$ & 7.69E-08 \\
\hline SN126 & 1.69E-03 & 1.83E-03 & $2.00 \mathrm{E}-03$ & $2.16 \mathrm{E}-03$ & $2.30 \mathrm{E}-03$ & $2.40 \mathrm{E}-03$ & $2.47 \mathrm{E}-03$ & $2.51 \mathrm{E}-03$ & $2.52 \mathrm{E}-03$ & $2.50 \mathrm{E}-03$ & $2.45 \mathrm{E}-03$ & 2.37E-03 & $2.25 \mathrm{E}-03$ & $2.11 \mathrm{E}-03$ & $1.94 \mathrm{E}-03$ & $1.75 \mathrm{E}-03$ & $1.54 \mathrm{E}-03$ & $1.34 \mathrm{E}-03$ \\
\hline SB126 & 8.02E-11 & 8.67E-11 & 9.50E-11 & $1.03 \mathrm{E}-10$ & 1.09E-10 & 1.14E-10 & 1.17E-10 & 1.19E-10 & 1.20E-10 & 1.19E-10 & 1.16E-10 & 1.12E-10 & $1.07 \mathrm{E}-10$ & $1.00 \mathrm{E}-10$ & $9.23 \mathrm{E}-11$ & $8.31 \mathrm{E}-11$ & $7.31 \mathrm{E}-11$ & $6.38 \mathrm{E}-11$ \\
\hline TE126 & $6.78 \mathrm{E}-05$ & $7.66 \mathrm{E}-05$ & $8.78 \mathrm{E}-05$ & 9.87E-05 & $1.08 \mathrm{E}-04$ & 1.16E-04 & $1.22 \mathrm{E}-04$ & 1.25E-04 & 1.26E-04 & 1.24E-04 & 1.20E-04 & 1.14E-04 & $1.06 \mathrm{E}-04$ & $9.55 \mathrm{E}-05$ & 8.43E-05 & 7.23E-05 & $6.03 \mathrm{E}-05$ & 4.99E-05 \\
\hline TE127 & $1.56 \mathrm{E}-26$ & $1.66 \mathrm{E}-26$ & $1.80 \mathrm{E}-26$ & $1.93 \mathrm{E}-26$ & $3.17 \mathrm{E}-26$ & $3.30 \mathrm{E}-26$ & 3.39E-26 & $3.44 \mathrm{E}-26$ & $3.45 \mathrm{E}-26$ & 3.43E-26 & $3.37 \mathrm{E}-26$ & $3.28 \mathrm{E}-26$ & $3.15 \mathrm{E}-26$ & $1.90 \mathrm{E}-26$ & $1.77 \mathrm{E}-26$ & $1.61 \mathrm{E}-26$ & $1.44 \mathrm{E}-26$ & $1.28 \mathrm{E}-26$ \\
\hline
\end{tabular}

lxxxix 


\begin{tabular}{|c|c|c|c|c|c|c|c|c|c|c|c|c|c|c|c|c|c|c|}
\hline TE127M & $0.00 \mathrm{E}+00$ & $0.00 \mathrm{E}+00$ & $0.00 \mathrm{E}+00$ & $0.00 \mathrm{E}+00$ & $9.07 \mathrm{E}-24$ & $9.43 \mathrm{E}-24$ & $9.68 \mathrm{E}-24$ & $9.83 \mathrm{E}-24$ & $9.87 \mathrm{E}-24$ & $9.81 \mathrm{E}-24$ & $9.65 \mathrm{E}-24$ & $9.37 \mathrm{E}-24$ & $9.00 \mathrm{E}-24$ & $0.00 \mathrm{E}+00$ & $0.00 \mathrm{E}+00$ & $0.00 \mathrm{E}+00$ & $0.00 \mathrm{E}+00$ & $0.00 \mathrm{E}+00$ \\
\hline 1127 & 2.96E-03 & 3.16E-03 & $3.44 \mathrm{E}-03$ & $3.70 \mathrm{E}-03$ & $3.92 \mathrm{E}-03$ & $4.08 \mathrm{E}-03$ & $4.20 \mathrm{E}-03$ & 4.26E- 03 & 4.28E-03 & 4.25E-03 & $4.16 \mathrm{E}-03$ & 4.03E-03 & $3.85 \mathrm{E}-03$ & 3.62E-03 & $3.34 \mathrm{E}-03$ & $3.03 \mathrm{E}-03$ & $2.68 \mathrm{E}-03$ & $2.37 \mathrm{E}-03$ \\
\hline TE128 & $5.52 \mathrm{E}-03$ & $5.90 \mathrm{E}-03$ & $6.44 \mathrm{E}-03$ & $6.94 \mathrm{E}-03$ & $7.35 \mathrm{E}-03$ & $7.68 \mathrm{E}-03$ & $7.91 \mathrm{E}-03$ & $8.03 \mathrm{E}-03$ & $8.07 \mathrm{E}-03$ & $8.00 \mathrm{E}-03$ & $7.84 \mathrm{E}-03$ & $7.58 \mathrm{E}-03$ & $7.22 \mathrm{E}-03$ & $6.78 \mathrm{E}-03$ & $6.25 \mathrm{E}-03$ & $5.64 \mathrm{E}-03$ & $4.98 \mathrm{E}-03$ & $4.40 \mathrm{E}-03$ \\
\hline
\end{tabular}
Position=Segment location (midpoint of 2-in. segment) from bottom of fuel (BOF); 2 in. of fuel $\sim 14.2 \mathrm{~g}$ 
Table A-2g. Composition (grams) in 2-inch fuel segment: ORIGEN calculation results for Pin193045, decayed to 3/11/2011.

\begin{tabular}{|c|c|c|c|c|c|c|c|c|c|c|c|c|c|c|c|c|c|c|}
\hline Position: & 1 & 3 & 5 & 7 & 9 & 11 & 13 & 15 & 17 & 19 & 21 & 23 & 25 & 27 & 29 & 31 & 33 & 35 \\
\hline XE128 & $9.75 \mathrm{E}-05$ & $1.21 \mathrm{E}-04$ & 1.49E-04 & $1.77 \mathrm{E}-04$ & $2.02 E-04$ & $2.22 \mathrm{E}-04$ & $2.37 \mathrm{E}-04$ & $2.46 \mathrm{E}-04$ & $2.48 \mathrm{E}-04$ & $2.44 \mathrm{E}-04$ & $2.33 \mathrm{E}-04$ & 2.16E-04 & $1.94 \mathrm{E}-04$ & $1.69 \mathrm{E}-04$ & $1.41 \mathrm{E}-04$ & $1.13 \mathrm{E}-04$ & $8.50 \mathrm{E}-05$ & $6.11 \mathrm{E}-05$ \\
\hline TE129 & $0.00 E+00$ & $0.00 E+00$ & $0.00 E+00$ & $0.00 \mathrm{E}+00$ & $0.00 \mathrm{E}+00$ & $0.00 \mathrm{E}+00$ & $0.00 E+00$ & $0.00 \mathrm{E}+00$ & $0.00 E+00$ & $0.00 \mathrm{E}+00$ & $0.00 \mathrm{E}+00$ & $0.00 \mathrm{E}+00$ & $0.00 E+00$ & $0.00 E+00$ & $0.00 \mathrm{E}+00$ & $0.00 \mathrm{E}+00$ & $0.00 \mathrm{E}+00$ & $0.00 \mathrm{E}+00$ \\
\hline TE129M & $0.00 \mathrm{E}+00$ & $0.00 \mathrm{E}+00$ & $0.00 E+00$ & $0.00 \mathrm{E}+00$ & $0.00 \mathrm{E}+00$ & $0.00 \mathrm{E}+00$ & $0.00 \mathrm{E}+00$ & $0.00 \mathrm{E}+00$ & $0.00 \mathrm{E}+00$ & $0.00 \mathrm{E}+00$ & $0.00 \mathrm{E}+00$ & $0.00 \mathrm{E}+00$ & $0.00 \mathrm{E}+00$ & $0.00 \mathrm{E}+00$ & $0.00 \mathrm{E}+00$ & $0.00 \mathrm{E}+00$ & $0.00 \mathrm{E}+00$ & $0.00 \mathrm{E}+00$ \\
\hline 1129 & $8.08 \mathrm{E}-03$ & $8.60 \mathrm{E}-03$ & $9.35 \mathrm{E}-03$ & $1.01 \mathrm{E}-02$ & $1.06 \mathrm{E}-02$ & 1.11E-02 & 1.14E-02 & 1.16E-02 & 1.17E-02 & 1.16E-02 & $1.13 \mathrm{E}-02$ & $1.10 \mathrm{E}-02$ & $1.05 \mathrm{E}-02$ & $9.82 \mathrm{E}-03$ & $9.07 \mathrm{E}-03$ & $8.20 \mathrm{E}-03$ & $7.27 \mathrm{E}-03$ & $6.45 \mathrm{E}-03$ \\
\hline XE129 & $7.93 \mathrm{E}-07$ & 1.13E-06 & $1.55 \mathrm{E}-06$ & $2.01 \mathrm{E}-06$ & $2.46 \mathrm{E}-06$ & $2.85 \mathrm{E}-06$ & $3.16 \mathrm{E}-06$ & $3.34 \mathrm{E}-06$ & $3.38 \mathrm{E}-06$ & $3.29 \mathrm{E}-06$ & $3.07 \mathrm{E}-06$ & $2.74 \mathrm{E}-06$ & $2.33 \mathrm{E}-06$ & $1.88 \mathrm{E}-06$ & 1.43E-06 & $1.02 E-06$ & $6.69 \mathrm{E}-07$ & $4.05 \mathrm{E}-07$ \\
\hline TE130 & $1.44 \mathrm{E}-02$ & $1.54 \mathrm{E}-02$ & $1.67 \mathrm{E}-02$ & $1.80 \mathrm{E}-02$ & $1.91 \mathrm{E}-02$ & $2.00 \mathrm{E}-02$ & $2.06 \mathrm{E}-02$ & $2.09 \mathrm{E}-02$ & $2.10 \mathrm{E}-02$ & $2.08 \mathrm{E}-02$ & $2.04 \mathrm{E}-02$ & $1.97 \mathrm{E}-02$ & $1.88 \mathrm{E}-02$ & $1.76 \mathrm{E}-02$ & $1.62 \mathrm{E}-02$ & $1.46 \mathrm{E}-02$ & $1.29 \mathrm{E}-02$ & 1.15E-02 \\
\hline XE130 & $2.34 \mathrm{E}-04$ & $2.88 \mathrm{E}-04$ & 3.54E-04 & $4.20 \mathrm{E}-04$ & $4.79 \mathrm{E}-04$ & $5.28 \mathrm{E}-04$ & $5.63 \mathrm{E}-04$ & $5.84 \mathrm{E}-04$ & $5.90 \mathrm{E}-04$ & $5.79 \mathrm{E}-04$ & $5.53 \mathrm{E}-04$ & $5.13 \mathrm{E}-04$ & $4.62 E-04$ & $4.01 \mathrm{E}-04$ & $3.35 \mathrm{E}-04$ & $2.67 \mathrm{E}-04$ & $2.02 \mathrm{E}-04$ & $1.47 \mathrm{E}-04$ \\
\hline |131 & $0.00 \mathrm{E}+00$ & $0.00 \mathrm{E}+00$ & $0.00 \mathrm{E}+00$ & $0.00 \mathrm{E}+00$ & $0.00 \mathrm{E}+00$ & $0.00 \mathrm{E}+00$ & $0.00 \mathrm{E}+00$ & $0.00 \mathrm{E}+00$ & $0.00 \mathrm{E}+00$ & $0.00 \mathrm{E}+00$ & $0.00 \mathrm{E}+00$ & $0.00 \mathrm{E}+00$ & $0.00 \mathrm{E}+00$ & $0.00 \mathrm{E}+00$ & $0.00 \mathrm{E}+00$ & $0.00 \mathrm{E}+00$ & $0.00 \mathrm{E}+00$ & $0.00 \mathrm{E}+00$ \\
\hline XE131 & $2.36 \mathrm{E}-02$ & $2.50 \mathrm{E}-02$ & $2.72 E-02$ & $2.92 \mathrm{E}-02$ & $3.10 \mathrm{E}-02$ & $3.23 \mathrm{E}-02$ & $3.33 \mathrm{E}-02$ & $3.38 \mathrm{E}-02$ & $3.39 \mathrm{E}-02$ & $3.37 \mathrm{E}-02$ & $3.30 \mathrm{E}-02$ & $3.19 \mathrm{E}-02$ & $3.04 \mathrm{E}-02$ & $2.86 \mathrm{E}-02$ & $2.64 \mathrm{E}-02$ & $2.38 \mathrm{E}-02$ & $2.11 \mathrm{E}-02$ & $1.88 \mathrm{E}-02$ \\
\hline XE131M & $0.00 E+00$ & $0.00 \mathrm{E}+00$ & $0.00 E+00$ & $0.00 \mathrm{E}+00$ & $0.00 \mathrm{E}+00$ & $0.00 E+00$ & $0.00 E+00$ & $0.00 \mathrm{E}+00$ & $0.00 \mathrm{E}+00$ & $0.00 E+00$ & $0.00 \mathrm{E}+00$ & $0.00 E+00$ & $0.00 E+00$ & $0.00 E+00$ & $0.00 E+00$ & $0.00 \mathrm{E}+00$ & $0.00 \mathrm{E}+00$ & $0.00 E+00$ \\
\hline XE132 & $3.44 \mathrm{E}-02$ & $3.66 \mathrm{E}-02$ & $3.98 \mathrm{E}-02$ & $4.30 \mathrm{E}-02$ & $4.56 \mathrm{E}-02$ & $4.77 \mathrm{E}-02$ & $4.91 \mathrm{E}-02$ & $4.99 \mathrm{E}-02$ & $5.01 \mathrm{E}-02$ & $4.97 \mathrm{E}-02$ & $4.87 \mathrm{E}-02$ & $4.70 \mathrm{E}-02$ & $4.48 \mathrm{E}-02$ & $4.20 \mathrm{E}-02$ & $3.86 \mathrm{E}-02$ & $3.48 \mathrm{E}-02$ & $3.08 \mathrm{E}-02$ & $2.73 \mathrm{E}-02$ \\
\hline BA132 & $3.48 \mathrm{E}-08$ & $4.27 \mathrm{E}-08$ & $5.25 \mathrm{E}-08$ & $6.21 \mathrm{E}-08$ & $7.09 \mathrm{E}-08$ & $7.81 \mathrm{E}-08$ & $8.34 \mathrm{E}-08$ & $8.65 \mathrm{E}-08$ & $8.73 \mathrm{E}-08$ & $8.57 \mathrm{E}-08$ & $8.19 \mathrm{E}-08$ & $7.59 \mathrm{E}-08$ & $6.83 \mathrm{E}-08$ & $5.93 \mathrm{E}-08$ & $4.96 \mathrm{E}-08$ & $3.96 \mathrm{E}-08$ & $3.00 \mathrm{E}-08$ & $2.18 \mathrm{E}-08$ \\
\hline XE133 & $0.00 E+00$ & $0.00 \mathrm{E}+00$ & $0.00 E+00$ & $0.00 \mathrm{E}+00$ & $0.00 \mathrm{E}+00$ & $0.00 \mathrm{E}+00$ & $0.00 \mathrm{E}+00$ & $0.00 \mathrm{E}+00$ & $0.00 \mathrm{E}+00$ & $0.00 \mathrm{E}+00$ & $0.00 \mathrm{E}+00$ & $0.00 \mathrm{E}+00$ & $0.00 \mathrm{E}+00$ & $0.00 \mathrm{E}+00$ & $0.00 \mathrm{E}+00$ & $0.00 \mathrm{E}+00$ & $0.00 \mathrm{E}+00$ & $0.00 \mathrm{E}+00$ \\
\hline CS133 & $4.62 E-02$ & $4.87 \mathrm{E}-02$ & $5.28 \mathrm{E}-02$ & $5.66 \mathrm{E}-02$ & $5.98 \mathrm{E}-02$ & $6.22 \mathrm{E}-02$ & $6.39 \mathrm{E}-02$ & $6.49 \mathrm{E}-02$ & $6.52 E-02$ & $6.47 \mathrm{E}-02$ & $6.34 \mathrm{E}-02$ & $6.14 \mathrm{E}-02$ & $5.87 \mathrm{E}-02$ & $5.53 \mathrm{E}-02$ & $5.12 \mathrm{E}-02$ & $4.64 \mathrm{E}-02$ & $4.14 \mathrm{E}-02$ & $3.70 \mathrm{E}-02$ \\
\hline XE134 & $5.57 \mathrm{E}-02$ & $5.91 \mathrm{E}-02$ & $6.42 \mathrm{E}-02$ & $6.91 \mathrm{E}-02$ & $7.32 E-02$ & $7.64 \mathrm{E}-02$ & $7.86 \mathrm{E}-02$ & $7.99 \mathrm{E}-02$ & $8.02 E-02$ & $7.96 \mathrm{E}-02$ & $7.80 \mathrm{E}-02$ & $7.54 \mathrm{E}-02$ & 7.19E-02 & $6.75 \mathrm{E}-02$ & $6.22 \mathrm{E}-02$ & $5.62 \mathrm{E}-02$ & $4.99 \mathrm{E}-02$ & $4.44 \mathrm{E}-02$ \\
\hline CS134 & $2.04 \mathrm{E}-06$ & $2.50 \mathrm{E}-06$ & $3.05 \mathrm{E}-06$ & $3.60 \mathrm{E}-06$ & $4.09 \mathrm{E}-06$ & $4.50 \mathrm{E}-06$ & $4.79 \mathrm{E}-06$ & $4.97 \mathrm{E}-06$ & $5.01 \mathrm{E}-06$ & $4.93 \mathrm{E}-06$ & $4.71 \mathrm{E}-06$ & $4.38 \mathrm{E}-06$ & $3.95 \mathrm{E}-06$ & $3.45 \mathrm{E}-06$ & $2.89 \mathrm{E}-06$ & $2.32 \mathrm{E}-06$ & $1.77 \mathrm{E}-06$ & 1.29E-06 \\
\hline BA134 & $1.68 \mathrm{E}-03$ & $2.05 E-03$ & $2.51 \mathrm{E}-03$ & $2.97 \mathrm{E}-03$ & $3.38 \mathrm{E}-03$ & $3.72 \mathrm{E}-03$ & $3.96 \mathrm{E}-03$ & 4.11E-03 & $4.14 \mathrm{E}-03$ & 4.07E-03 & $3.89 \mathrm{E}-03$ & $3.62 \mathrm{E}-03$ & $3.26 \mathrm{E}-03$ & $2.84 \mathrm{E}-03$ & $2.38 \mathrm{E}-03$ & $1.90 \mathrm{E}-03$ & $1.45 \mathrm{E}-03$ & $1.06 \mathrm{E}-03$ \\
\hline CS135 & $4.71 \mathrm{E}-02$ & $5.00 \mathrm{E}-02$ & $5.44 \mathrm{E}-02$ & $5.86 \mathrm{E}-02$ & $6.22 \mathrm{E}-02$ & $6.50 \mathrm{E}-02$ & $6.69 \mathrm{E}-02$ & $6.80 \mathrm{E}-02$ & $6.83 \mathrm{E}-02$ & $6.77 \mathrm{E}-02$ & $6.63 \mathrm{E}-02$ & $6.41 \mathrm{E}-02$ & $6.11 \mathrm{E}-02$ & $5.72 E-02$ & $5.27 \mathrm{E}-02$ & $4.76 \mathrm{E}-02$ & $4.21 \mathrm{E}-02$ & $3.74 \mathrm{E}-02$ \\
\hline BA135 & $2.42 \mathrm{E}-06$ & $3.33 \mathrm{E}-06$ & $4.51 \mathrm{E}-06$ & $5.78 \mathrm{E}-06$ & $7.03 \mathrm{E}-06$ & $8.12 \mathrm{E}-06$ & $8.95 \mathrm{E}-06$ & $9.45 \mathrm{E}-06$ & $9.58 \mathrm{E}-06$ & $9.32 \mathrm{E}-06$ & $8.70 \mathrm{E}-06$ & $7.78 \mathrm{E}-06$ & $6.65 \mathrm{E}-06$ & $5.41 \mathrm{E}-06$ & $4.16 \mathrm{E}-06$ & $3.01 \mathrm{E}-06$ & $2.03 \mathrm{E}-06$ & $1.29 \mathrm{E}-06$ \\
\hline XE136 & 4.77E-02 & $5.06 \mathrm{E}-02$ & $5.50 \mathrm{E}-02$ & $5.93 \mathrm{E}-02$ & $6.29 \mathrm{E}-02$ & $6.56 \mathrm{E}-02$ & $6.76 \mathrm{E}-02$ & $6.87 \mathrm{E}-02$ & $6.90 \mathrm{E}-02$ & $6.84 \mathrm{E}-02$ & $6.70 \mathrm{E}-02$ & $6.48 \mathrm{E}-02$ & $6.17 \mathrm{E}-02$ & $5.79 \mathrm{E}-02$ & $5.33 \mathrm{E}-02$ & $4.82 \mathrm{E}-02$ & 4.27E-02 & $3.79 \mathrm{E}-02$ \\
\hline CS136 & $0.00 \mathrm{E}+00$ & $0.00 E+00$ & $0.00 \mathrm{E}+00$ & $0.00 E+00$ & $0.00 \mathrm{E}+00$ & $0.00 \mathrm{E}+00$ & $0.00 \mathrm{E}+00$ & $0.00 \mathrm{E}+00$ & $0.00 E+00$ & $0.00 \mathrm{E}+00$ & $0.00 E+00$ & $0.00 \mathrm{E}+00$ & $0.00 \mathrm{E}+00$ & $0.00 E+00$ & $0.00 \mathrm{E}+00$ & $0.00 \mathrm{E}+00$ & $0.00 \mathrm{E}+00$ & $0.00 \mathrm{E}+00$ \\
\hline
\end{tabular}




\begin{tabular}{|c|c|c|c|c|c|c|c|c|c|c|c|c|c|c|c|c|c|c|}
\hline BA136 & 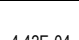 & совг & & & & & & & & & & & & & $50 \Gamma 0$ & 150 & & 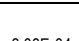 \\
\hline CS137 & $2.80 \mathrm{E}-02$ & $2.97 \mathrm{E}-02$ & $3.23 \mathrm{E}-02$ & $3.48 \mathrm{E}-02$ & $3.69 \mathrm{E}-02$ & $3.85 \mathrm{E}-02$ & $3.97 E-02$ & $4.03 E-02$ & $4.05 E-02$ & $4.011 \mathrm{E}-02$ & $3.93 E-022$ & $3.80 \mathrm{E}-02$ & $3.62 E-02$ & $3.40 \mathrm{E}-02$ & $3.13 \mathrm{E}-02$ & $2.83 \mathrm{E}-02$ & $2.51 \mathrm{E}-02$ & $2.23 E-02$ \\
\hline BA137 & 1.7 & $1.82 \mathrm{E}-02$ & $1.98 \mathrm{E}-02$ & $2.14 \mathrm{E}-02$ & $2.27 \mathrm{E}-02$ & $2.37 \mathrm{E}-02$ & $2.44 \mathrm{E}-02$ & $2.48 \mathrm{E}-02$ & $2.49 \mathrm{E}-02$ & 7E-02 & $2.42 E-02$ & $2.34 \mathrm{E}-02$ & $2.23 \mathrm{E}-02$ & $2.09 \mathrm{E}-02$ & $92 \mathrm{E}-02$ & $1.74 \mathrm{E}-02$ & $1.54 \mathrm{E}-02$ & $1.37 \mathrm{E}-02$ \\
\hline
\end{tabular}
Position=Segment location (midpoint of 2 -in. segment) from bottom of fuel (BOF); 2 in. of fuel $\sim 14.2 \mathrm{~g}$ 
Table A-2h. Composition (grams) in 2-inch fuel segment: ORIGEN calculation results for Pin193045, decayed to 3/11/2011.

\begin{tabular}{|c|c|c|c|c|c|c|c|c|c|c|c|c|c|c|c|c|c|c|}
\hline BA138 & $4.90 E-02$ & $\begin{array}{r}5.19 \mathrm{E}-02 \\
\end{array}$ & $5.64 \mathrm{E}-02$ & $6.07 \mathrm{E}-02$ & $\begin{array}{r}6.43 \mathrm{E}-02 \\
\end{array}$ & $6.72 E-02$ & $6.92 \mathrm{E}-02$ & $\begin{array}{r}7.03 E-02 \\
\end{array}$ & $\begin{array}{r}7.06 \mathrm{E}-02 \\
\end{array}$ & $\begin{array}{r}7.00 E-02 \\
\end{array}$ & $\begin{array}{r}6.86 \mathrm{E}-02 \\
\end{array}$ & $6.63 \mathrm{E}-02$ & $6.32 \mathrm{E}-02$ & $\begin{array}{r}5.93 \mathrm{E}-02 \\
\end{array}$ & $\begin{array}{r}5.47 \mathrm{E}-02 \\
\end{array}$ & $4.94 \mathrm{E}-02$ & $\begin{array}{r}4.38 \mathrm{E}-02 \\
\end{array}$ & $\begin{array}{r}3.90 \mathrm{E}-02 \\
\end{array}$ \\
\hline LA138 & 1.93E-07 & $2.02 E-07$ & 2.18E-07 & $\begin{array}{r}2.34 \mathrm{E}-07 \\
\end{array}$ & 2.47E-07 & $2.57 E-07$ & $2.65 \mathrm{E}-07$ & 2.69E-07 & $\begin{array}{r}2.70 \mathrm{E}-07 \\
\end{array}$ & $2.68 \mathrm{E}-07$ & $2.62 E-07$ & $2.54 \mathrm{E}-07$ & 2.43E-07 & 2.28E-07 & 2.11E-07 & $1.92 E-07$ & 1.71E-07 & $1.54 \mathrm{E}-07$ \\
\hline LA139 & $4.76 E-02$ & $5.05 E-02$ & $5.48 E-02$ & $5.90 \mathrm{E}-02$ & $6.25 \mathrm{E}-02$ & $6.52 E-02$ & $6.71 \mathrm{E}-02$ & $6.82 E-02$ & $6.85 \mathrm{E}-02$ & $6.79 \mathrm{E}-02$ & $6.66 \mathrm{E}-02$ & $6.44 \mathrm{E}-02$ & $6.14 \mathrm{E}-02$ & $5.76 \mathrm{E}-02$ & $5.32 \mathrm{E}-02$ & $4.80 \mathrm{E}-02$ & $4.26 \mathrm{E}-02$ & $\begin{array}{l}3.79 \mathrm{E}-02 \\
\end{array}$ \\
\hline BA140 & $0.00 E+00$ & $0.00 E+00$ & $0.00 E+00$ & $0.00 E+00$ & $0.00 E+00$ & $0.00 E+00$ & $0.00 E+00$ & $0.00 E+00$ & $0.00 E+00$ & $0.00 E+00$ & $0.00 E+00$ & $0.00 E+00$ & $0.00 E+00$ & $0.00 E+00$ & $0.00 E+00$ & $0.00 E+00$ & $0.00 E+00$ & $0.00 E+00$ \\
\hline LA140 & $0.00 E+00$ & $0.00 E+00$ & $0.00 E+00$ & $0.00 E+00$ & $0.00 E+00$ & $0.00 E+00$ & $0.00 E+00$ & $0.00 E+00$ & $0.00 E+00$ & $0.00 E+00$ & $0.00 E+00$ & $0.00 \mathrm{E}+00$ & $0.00 E+00$ & $0.00 E+00$ & $0.00 E+00$ & $0.00 E+00$ & $0.00 E+00$ & $0.00 E+00$ \\
\hline CE140 & $4.66 \mathrm{E}-02$ & $4.93 \mathrm{E}-02$ & $5.36 \mathrm{E}-02$ & $5.77 \mathrm{E}-02$ & $6.12 \mathrm{E}-02$ & $6.38 \mathrm{E}-02$ & $6.57 \mathrm{E}-02$ & $6.68 \mathrm{E}-02$ & $6.71 \mathrm{E}-02$ & $6.65 \mathrm{E}-02$ & $6.52 \mathrm{E}-02$ & $6.30 \mathrm{E}-02$ & $6.01 \mathrm{E}-02$ & $5.64 \mathrm{E}-02$ & $5.20 \mathrm{E}-02$ & 4.70E-02 & $4.16 \mathrm{E}-02$ & $3.71 \mathrm{E}-02$ \\
\hline CE141 & $0.00 E+00$ & $0.00 E+00$ & $0.00 E+00$ & $0.00 E+00$ & $0.00 E+00$ & $0.00 E+00$ & $0.00 E+00$ & $0.00 E+00$ & $0.00 E+00$ & $0.00 E+00$ & $0.00 E+00$ & $0.00 E+00$ & $0.00 E+00$ & $0.00 E+00$ & $0.00 E+00$ & $0.00 E+00$ & $0.00 E+00$ & $0.00 E+00$ \\
\hline PR141 & $4.51 \mathrm{E}-02$ & $4.77 \mathrm{E}-02$ & $5.18 E-02$ & $5.57 \mathrm{E}-02$ & $5.89 E-02$ & $6.15 E-02$ & $6.32 E-02$ & $6.42 E-02$ & $6.45 \mathrm{E}-02$ & $6.40 \mathrm{E}-02$ & $6.27 E-02$ & $6.07 E-02$ & $\begin{array}{r}5.79 \mathrm{E}-02 \\
\end{array}$ & $5.44 \mathrm{E}-02$ & $5.02 E-02$ & $4.54 E-02$ & $4.03 E-02$ & $3.60 \mathrm{E}-02$ \\
\hline CE142 & $4.26 E-02$ & $4.51 \mathrm{E}-02$ & $\begin{array}{l}4.90 E-02 \\
\end{array}$ & $5.27 \mathrm{E}-02$ & $5.59 E-02$ & $5.83 \mathrm{E}-02$ & $6.00 E-02$ & $6.10 E-02$ & $6.12 \mathrm{E}-02$ & $6.07 E-02$ & $5.95 E-02$ & $5.75 \mathrm{E}-02$ & $\begin{array}{r}5.49 \mathrm{E}-02 \\
\end{array}$ & $5.15 \mathrm{E}-02$ & $4.75 \mathrm{E}-02$ & 4.30E-02 & $3.81 E-02$ & $3.40 \mathrm{E}-02$ \\
\hline ND142 & 4.49E-04 & $5.52 \mathrm{E}-04$ & $6.78 E-04$ & $8.04 \mathrm{E}-04$ & $9.18 E-04$ & $1.01 E-03$ & $1.08 E-03$ & 1.12E-03 & 1.13E-03 & 1.11E-03 & $1.06 E-03$ & $9.85 \mathrm{E}-04$ & $8.85 \mathrm{E}-04$ & $7.68 \mathrm{E}-04$ & $6.40 \mathrm{E}-04$ & $5.10 \mathrm{E}-04$ & $3.86 \mathrm{E}-04$ & $2.81 \mathrm{E}-04$ \\
\hline PR143 & $0.00 E+00$ & $0.00 E+00$ & $0.00 E+00$ & $0.00 E+00$ & $0.00 E+00$ & $0.00 E+00$ & $0.00 E+00$ & $0.00 E+00$ & $0.00 E+00$ & $0.00 E+00$ & $0.00 E+00$ & $0.00 \mathrm{E}+00$ & $0.00 E+00$ & $0.00 E+00$ & $0.00 E+00$ & $0.00 E+00$ & $0.00 E+00$ & $0.00 E+00$ \\
\hline ND143 & $4.29 E-02$ & $4.52 \mathrm{E}-02$ & $\begin{array}{l}4.89 E-02 \\
\end{array}$ & $\begin{array}{r}5.25 \mathrm{E}-02 \\
\end{array}$ & $5.55 \mathrm{E}-02$ & $5.78 \mathrm{E}-02$ & $5.94 \mathrm{E}-02$ & $6.03 E-02$ & $6.06 \mathrm{E}-02$ & $6.01 \mathrm{E}-02$ & $5.89 \mathrm{E}-02$ & $5.71 \mathrm{E}-02$ & $5.45 \mathrm{E}-02$ & $5.13 \mathrm{E}-02$ & $4.75 \mathrm{E}-02$ & $4.31 \mathrm{E}-02$ & $3.83 \mathrm{E}-02$ & $3.43 \mathrm{E}-02$ \\
\hline $\begin{array}{l}\text { CE144 } \\
\text {. }\end{array}$ & $5.76 E-10$ & $6.04 E-10$ & $6.51 E-10$ & $6.95 E-10$ & 7.32E-10 & 7.60E-10 & $7.79 E-10$ & $7.91 E-10$ & $7.94 E-10$ & $7.89 \mathrm{E}-10$ & $7.76 E-10$ & 7.54E-10 & $\begin{array}{l}7.23 E-10 \\
\end{array}$ & $6.84 \mathrm{E}-10$ & $6.37 E-10$ & $5.81 \mathrm{E}-10$ & $5.21 E-10$ & 4.69E-10 \\
\hline PR144 & $2.43 E-14$ & $2.55 \mathrm{E}-14$ & $2.75 E-14$ & $2.93 E-14$ & $3.09 E-14$ & $3.21 \mathrm{E}-14$ & $3.29 E-14$ & $3.34 E-14$ & $3.35 E-14$ & $3.33 E-14$ & $3.28 E-14$ & 3.18E-14 & $3.05 E-14$ & $2.89 E-14$ & $2.69 \mathrm{E}-14$ & $2.45 E-14$ & $2.20 E-14$ & $1.98 E-14$ \\
\hline ND144 & $4.10 \mathrm{E}-02$ & $4.35 \mathrm{E}-02$ & $4.73 E-02$ & $5.10 \mathrm{E}-02$ & $5.41 \mathrm{E}-02$ & $5.65 \mathrm{E}-02$ & $5.82 E-02$ & $5.91 E-02$ & $5.94 \mathrm{E}-02$ & $5.89 \mathrm{E}-02$ & $5.77 E-02$ & $5.57 \mathrm{E}-02$ & $5.31 \mathrm{E}-02$ & $4.98 \mathrm{E}-02$ & $4.59 \mathrm{E}-02$ & $4.14 \mathrm{E}-02$ & $3.66 \mathrm{E}-02$ & $3.26 \mathrm{E}-02$ \\
\hline ND145 & $2.93 E-02$ & $3.10 \mathrm{E}-02$ & $3.36 \mathrm{E}-02$ & $3.61 \mathrm{E}-02$ & $3.81 \mathrm{E}-02$ & $3.97 E-02$ & $4.09 E-02$ & $4.15 E-02$ & $4.17 \mathrm{E}-02$ & $4.13 \mathrm{E}-02$ & $4.05 E-02$ & $3.92 E-02$ & $3.75 E-02$ & $3.52 \mathrm{E}-02$ & $3.26 \mathrm{E}-02$ & $2.95 E-02$ & $2.62 E-02$ & $2.34 \mathrm{E}-02$ \\
\hline ND146 & $2.38 E-02$ & $2.53 \mathrm{E}-02$ & $2.76 E-02$ & $2.98 \mathrm{E}-02$ & $3.16 E-02$ & $3.31 E-02$ & $3.41 E-02$ & $3.47 E-02$ & $3.48 \mathrm{E}-02$ & $3.45 E-02$ & $3.38 E-02$ & $3.26 \mathrm{E}-02$ & $3.11 E-02$ & $2.91 E-02$ & $2.68 \mathrm{E}-02$ & $2.41 E-02$ & $.13 \mathrm{E}-02$ & $89 E-02$ \\
\hline PM146 & 1.34E- 07 & 1.62E-07 & $1.96 E-07$ & $2.30 \mathrm{E}-07$ & $2.59 E-07$ & $2.84 \mathrm{E}-07$ & $3.01 E-07$ & $3.12 E-07$ & $3.14 \mathrm{E}-07$ & $3.09 E-07$ & $2.96 E-07$ & $2.77 \mathrm{E}-07$ & $2.51 \mathrm{E}-07$ & $2.20 \mathrm{E}-07$ & $1.86 \mathrm{E}-07$ & $1.50 \mathrm{E}-07$ & 1.16E- -07 & $8.54 \mathrm{E}-08$ \\
\hline SM146 & 1.79E-06 & 2.17E-06 & $2.64 \mathrm{E}-06$ & $3.10 \mathrm{E}-06$ & $3.50 \mathrm{E}-06$ & $3.84 \mathrm{E}-06$ & 4.08E-06 & $4.22 E-06$ & $\begin{array}{r}4.26 \mathrm{E}-06 \\
\end{array}$ & 4.18E-06 & $4.01 E-06$ & $3.74 \mathrm{E}-06$ & $3.38 \mathrm{E}-06$ & $\begin{array}{l}2.96 \mathrm{E}-06 \\
\end{array}$ & $2.50 \mathrm{E}-06$ & 2.02E -06 & $1.55 E-06$ & $1.14 \mathrm{E}-06$ \\
\hline ND147 & $0.00 E+00$ & $0.00 E+00$ & $0.00 E+00$ & $0.00 E++00$ & $0.00 E+00$ & $0.00 E+00$ & $0.00 E+00$ & $0.00 E+00$ & $0.00 E+00$ & $0.00 E+00$ & $0.00 E+00$ & $0.00 \mathrm{E}+00$ & $0.00 E+00$ & $0.00 E+00$ & $0.00 E+00$ & $0.00 E+00$ & $0.00 E+00$ & $0.00 E+00$ \\
\hline PM147 & $\begin{array}{r}7.19 E-05 \\
\end{array}$ & $\begin{array}{r}7.44 \mathrm{E}-05 \\
\end{array}$ & $7.91 E-05$ & $8.34 \mathrm{E}-05$ & $\begin{array}{r}8.69 E-05 \\
\end{array}$ & $8.95 E-05$ & $9.13 \mathrm{E}-05$ & $9.23 \mathrm{E}-05$ & $9.26 \mathrm{E}-05$ & $9.21 \mathrm{E}-05$ & $9.08 E-05$ & $8.88 \mathrm{E}-05$ & $8.59 \mathrm{E}-05$ & $8.20 \mathrm{E}-05$ & $7.73 \mathrm{E}-05$ & 7.15E-05 & $6.50 \mathrm{E}-05$ & $94 \mathrm{E}-05$ \\
\hline SM147 & $1.63 E-02$ & 1.69E-02 & $\begin{array}{l}1.80 \mathrm{E}-02 \\
\end{array}$ & $1.91 \mathrm{E}-02$ & $1.99 E-02$ & $2.05 E-02$ & 2.10E-02 & 2.12E-02 & $2.13 \mathrm{E}-02$ & $2.11 \mathrm{E}-02$ & $2.08 E-02$ & $2.03 \mathrm{E}-02$ & $1.96 \mathrm{E}-02$ & $1.87 \mathrm{E}-02$ & $1.76 \mathrm{E}-02$ & $\begin{array}{l}1.62 E-02 \\
1.02\end{array}$ & $\begin{array}{l}1.47 E-02 \\
\end{array}$ & $1.34 \mathrm{E}-02$ \\
\hline ND148 & $1.37 \mathrm{E}-02$ & $1.46 \mathrm{E}-02$ & $1.58 \mathrm{E}-02$ & $1.70 \mathrm{E}-02$ & $\begin{array}{l}1.80 \mathrm{E}-22 \\
\end{array}$ & $1.88 \mathrm{E}-02$ & $1.94 E-02$ & $1.97 \overline{0}-22$ & $1.98 \mathrm{E}-02$ & $1.96 \mathrm{E}-02$ & $\begin{array}{l}1.92 \pi-02 \\
\end{array}$ & $1.86 \mathrm{E}-02$ & $1.77 E-02$ & $1.67 \mathrm{E}-02$ & $1.54 \mathrm{E}-02$ & $1.39 \mathrm{E}-02$ & $1.23 \mathrm{E}-02$ & $1.09 E-02$ \\
\hline PM148 & $0.00 E+00$ & $0.00 E+00$ & $0.00 E+00$ & $0.00 E+00$ & $0.00 E+00$ & $0.00 E+00$ & $0.00 E++00$ & $0.00 E+00$ & $0.00 E+00$ & $0.00 E++00$ & $0.00 E+00$ & $0.00 E+00$ & $0.00 E+00$ & $0.00 E+00$ & $0.00 E++00$ & $0.00 E+00$ & $0.00 E+00$ & $0.00 E++00$ \\
\hline
\end{tabular}

Position=Segment location (midpoint of 2-in. segment) from bottom of fuel (BOF); 2 in. of fuel $\sim 14.2 \mathrm{~g}$ 
Table A-2i. Composition (grams) in 2-inch fuel segment: ORIGEN calculation results for Pin193045, decayed to 3/11/2011.

\begin{tabular}{|c|c|c|c|c|c|c|c|c|c|c|c|c|c|c|c|c|c|c|}
\hline Position: & 1 & 3 & 5 & 7 & 9 & 11 & 13 & 15 & 17 & 19 & 21 & 23 & 25 & 27 & 29 & 31 & 33 & 35 \\
\hline PM148M & $0 E+00$ & $00 \mathrm{E}+00$ & $0.00 E+00$ & $0.00 \mathrm{E}+00$ & $0.00 \mathrm{E}+00$ & $0.00 \mathrm{E}+00$ & $0.00 \mathrm{E}+00$ & $0.00 \mathrm{E}+00$ & $0.00 \mathrm{E}+00$ & $0.00 E+00$ & $0.00 E+00$ & $0.00 E+00$ & $0.00 E+00$ & $0.00 E+00$ & $0.00 E+00$ & $0.00 E+00$ & $0.00 E+00$ & $0.00 E+00$ \\
\hline SM148 & $2.66 \mathrm{E}-03$ & $3.22 \mathrm{E}-03$ & $3.88 \mathrm{E}-03$ & 4.54E- 03 & $5.11 \mathrm{E}-03$ & $5.58 \mathrm{E}-03$ & $5.92 \mathrm{E}-03$ & $6.12 \mathrm{E}-03$ & $6.17 \mathrm{E}-03$ & $6.07 \mathrm{E}-03$ & $5.82 \mathrm{E}-03$ & $5.44 \mathrm{E}-03$ & 4.94E- 03 & $4.35 \mathrm{E}-03$ & 3.69E-03 & $2.99 \mathrm{E}-03$ & $2.31 \mathrm{E}-03$ & $1.71 \mathrm{E}-03$ \\
\hline SM149 & $8.63 \mathrm{E}-03$ & $9.13 \mathrm{E}-03$ & $9.89 \mathrm{E}-03$ & $1.06 \mathrm{E}-02$ & $1.12 \mathrm{E}-02$ & 1.16E-02 & $1.20 \mathrm{E}-02$ & $1.21 \mathrm{E}-02$ & 1.22E-02 & $1.21 \mathrm{E}-02$ & 1.19E-02 & 1.15E-02 & 1.10E-02 & $1.04 \mathrm{E}-02$ & $9.60 \mathrm{E}-03$ & $8.73 \mathrm{E}-03$ & $7.78 \mathrm{E}-03$ & $6.94 \mathrm{E}-03$ \\
\hline ND150 & $5.88 \mathrm{E}-03$ & $6.29 \mathrm{E}-03$ & $6.87 \mathrm{E}-03$ & $7.40 \mathrm{E}-03$ & $7.85 \mathrm{E}-03$ & $8.20 \mathrm{E}-03$ & $8.45 \mathrm{E}-03$ & $8.58 \mathrm{E}-03$ & $8.62 E-03$ & $8.55 \mathrm{E}-03$ & $8.37 \mathrm{E}-03$ & $8.09 \mathrm{E}-03$ & $7.71 \mathrm{E}-03$ & $7.23 \mathrm{E}-03$ & $6.66 \mathrm{E}-03$ & $6.01 \mathrm{E}-03$ & $5.31 \mathrm{E}-03$ & 4.68E-03 \\
\hline SM150 & $8.43 \mathrm{E}-04$ & $1.03 E-03$ & $1.27 \mathrm{E}-03$ & 1.49E-03 & $1.70 \mathrm{E}-03$ & $1.87 \mathrm{E}-03$ & $1.99 \mathrm{E}-03$ & $2.06 \mathrm{E}-03$ & $2.08 \mathrm{E}-03$ & $2.05 \mathrm{E}-03$ & $1.96 \mathrm{E}-03$ & 1.82E-03 & $1.64 \mathrm{E}-03$ & 1.43E-03 & 1.20E-03 & $9.61 \mathrm{E}-04$ & $7.31 \mathrm{E}-04$ & $5.32 \mathrm{E}-04$ \\
\hline SM151 & $3.01 \mathrm{E}-03$ & $3.18 \mathrm{E}-03$ & 3.43E-03 & $3.67 \mathrm{E}-03$ & $3.86 \mathrm{E}-03$ & $4.01 \mathrm{E}-03$ & $4.11 \mathrm{E}-03$ & 4.17E-03 & 4.18E-03 & $4.15 \mathrm{E}-03$ & $4.08 \mathrm{E}-03$ & $3.96 \mathrm{E}-03$ & 3.80E-03 & 3.59E-03 & $3.34 \mathrm{E}-03$ & $3.04 \mathrm{E}-03$ & $2.72 \mathrm{E}-03$ & $2.43 \mathrm{E}-03$ \\
\hline EU151 & $5.11 \mathrm{E}-04$ & 5.39E-04 & $5.81 \mathrm{E}-04$ & $6.19 \mathrm{E}-04$ & $6.51 \mathrm{E}-04$ & $6.75 \mathrm{E}-04$ & $6.92 \mathrm{E}-04$ & $7.01 \mathrm{E}-04$ & $7.04 \mathrm{E}-04$ & $6.99 \mathrm{E}-04$ & $6.87 \mathrm{E}-04$ & $6.67 \mathrm{E}-04$ & $6.40 \mathrm{E}-04$ & $6.06 \mathrm{E}-04$ & $5.65 \mathrm{E}-04$ & $5.16 \mathrm{E}-04$ & $4.62 \mathrm{E}-04$ & 4.14E-04 \\
\hline SM152 & 3.14E-03 & $3.44 \mathrm{E}-03$ & $3.84 \mathrm{E}-03$ & 4.22E- 03 & 4.54E-03 & $4.80 \mathrm{E}-03$ & 4.98E-03 & $5.09 \mathrm{E}-03$ & $5.12 \mathrm{E}-03$ & $5.06 \mathrm{E}-03$ & 4.93E-03 & $4.72 \mathrm{E}-03$ & 4.44E- 03 & 4.10E-03 & $3.71 \mathrm{E}-03$ & 3.27E-03 & 2.82E-03 & 2.41E- 03 \\
\hline EU152 & $2.16 \mathrm{E}-06$ & $2.56 \mathrm{E}-06$ & $3.01 \mathrm{E}-06$ & $3.43 \mathrm{E}-06$ & $.78 E-06$ & $4.06 \mathrm{E}-06$ & $4.26 \mathrm{E}-06$ & 4.37E-06 & $4.40 \mathrm{E}-06$ & $4.34 \mathrm{E}-06$ & $4.20 \mathrm{E}-06$ & $3.97 \mathrm{E}-06$ & 3.67E-06 & $3.30 \mathrm{E}-06$ & $2.87 \mathrm{E}-06$ & $2.39 \mathrm{E}-06$ & $1.90 \mathrm{E}-06$ & $1.45 \mathrm{E}-06$ \\
\hline GD152 & $3.36 \mathrm{E}-06$ & $3.96 \mathrm{E}-06$ & 4.65E-06 & $5.29 \mathrm{E}-06$ & $5.83 \mathrm{E}-06$ & $6.25 \mathrm{E}-06$ & $6.55 \mathrm{E}-06$ & $6.72 \mathrm{E}-06$ & $6.76 \mathrm{E}-06$ & $6.67 \mathrm{E}-06$ & $6.46 \mathrm{E}-06$ & $6.12 \mathrm{E}-06$ & $5.66 \mathrm{E}-06$ & $5.09 \mathrm{E}-06$ & 4.44E- 06 & $3.71 \mathrm{E}-06$ & $2.95 \mathrm{E}-06$ & $2.25 \mathrm{E}-06$ \\
\hline EU15: & $1.68 \mathrm{E}-03$ & $1.78 \mathrm{E}-03$ & $1.93 \mathrm{E}-03$ & $2.07 \mathrm{E}-03$ & 2.19E-03 & $2.28 \mathrm{E}-03$ & $2.34 \mathrm{E}-03$ & $2.37 \mathrm{E}-03$ & $2.38 \mathrm{E}-03$ & $2.37 \mathrm{E}-03$ & $2.32 \mathrm{E}-03$ & $2.25 \mathrm{E}-03$ & $2.15 \mathrm{E}-03$ & $2.03 \mathrm{E}-03$ & $1.88 \mathrm{E}-03$ & $1.71 \mathrm{E}-03$ & $1.52 \mathrm{E}-03$ & $1.35 \mathrm{E}-03$ \\
\hline GD15 & $6.05 E-16$ & $8.30 \mathrm{E}-16$ & 1.11E-15 & $1.39 E-15$ & $1.65 \mathrm{E}-15$ & 1.88E-15 & $2.05 \mathrm{E}-15$ & $2.15 \mathrm{E}-15$ & 2.17E-15 & 2.12E-15 & $2.00 \mathrm{E}-15$ & 1.82E-15 & 1.58E-15 & 1.32E-15 & 1.03E-15 & 7.61E-16 & $5.16 \mathrm{E}-16$ & $3.20 \mathrm{E}-16$ \\
\hline SM154 & $8.89 \mathrm{E}-04$ & $9.62 \mathrm{E}-04$ & $1.06 \mathrm{E}-03$ & 1.15E-03 & $1.23 \mathrm{E}-03$ & $1.29 \mathrm{E}-03$ & $1.33 \mathrm{E}-03$ & $1.36 \mathrm{E}-03$ & $1.36 \mathrm{E}-03$ & $1.35 \mathrm{E}-03$ & $1.32 \mathrm{E}-03$ & $1.27 \mathrm{E}-03$ & $1.20 \mathrm{E}-03$ & 1.12E-03 & $1.03 \mathrm{E}-03$ & $9.17 \mathrm{E}-04$ & $8.02 \mathrm{E}-04$ & $6.97 \mathrm{E}-04$ \\
\hline EU154 & 4.63E-05 & $5.63 \mathrm{E}-05$ & $6.81 \mathrm{E}-05$ & $7.94 \mathrm{E}-05$ & $8.95 \mathrm{E}-05$ & $9.76 \mathrm{E}-05$ & $1.04 \mathrm{E}-04$ & 1.07E-04 & $1.08 \mathrm{E}-04$ & $1.06 \mathrm{E}-04$ & $1.02 \mathrm{E}-04$ & $9.52 \mathrm{E}-05$ & $8.66 \mathrm{E}-05$ & $7.62 \mathrm{E}-05$ & $6.47 \mathrm{E}-05$ & $5.25 \mathrm{E}-05$ & $4.05 \mathrm{E}-05$ & $2.98 \mathrm{E}-05$ \\
\hline GD154 & $1.87 \mathrm{E}-04$ & 2.27E-04 & $2.75 \mathrm{E}-04$ & $3.21 \mathrm{E}-04$ & $3.61 \mathrm{E}-04$ & $3.94 \mathrm{E}-04$ & $4.18 \mathrm{E}-04$ & $4.32 \mathrm{E}-04$ & $4.35 \mathrm{E}-04$ & $4.28 \mathrm{E}-04$ & $4.11 \mathrm{E}-04$ & $3.84 \mathrm{E}-04$ & $3.49 \mathrm{E}-04$ & $3.08 \mathrm{E}-04$ & $2.61 \mathrm{E}-04$ & 2.12E-04 & $1.63 \mathrm{E}-04$ & $1.20 \mathrm{E}-04$ \\
\hline EU155 & $3.04 \mathrm{E}-05$ & 3.28E-05 & $3.62 \mathrm{E}-05$ & $3.94 \mathrm{E}-05$ & 4.22E- 05 & $4.44 \mathrm{E}-05$ & $4.60 \mathrm{E}-05$ & 4.69E-05 & 4.71E-05 & $4.67 \mathrm{E}-05$ & $4.55 \mathrm{E}-05$ & $4.38 \mathrm{E}-05$ & $4.14 \mathrm{E}-05$ & $3.84 \mathrm{E}-05$ & $3.50 \mathrm{E}-05$ & $3.13 \mathrm{E}-05$ & $2.74 \mathrm{E}-05$ & $2.39 \mathrm{E}-05$ \\
\hline GD155 & $5.01 \mathrm{E}-04$ & $5.40 \mathrm{E}-04$ & $5.94 \mathrm{E}-04$ & $6.46 \mathrm{E}-04$ & $6.90 \mathrm{E}-04$ & $7.26 \mathrm{E}-04$ & $7.51 \mathrm{E}-04$ & $7.65 \mathrm{E}-04$ & 7.69E-04 & $7.61 \mathrm{E}-04$ & $7.43 \mathrm{E}-04$ & $7.14 \mathrm{E}-04$ & $6.76 \mathrm{E}-04$ & $6.30 \mathrm{E}-04$ & $5.75 \mathrm{E}-04$ & $5.15 \mathrm{E}-04$ & $4.51 \mathrm{E}-04$ & $3.95 \mathrm{E}-04$ \\
\hline EU156 & $0.00 \mathrm{E}+00$ & $0.00 \mathrm{E}+00$ & $0.00 \mathrm{E}+00$ & $0.00 \mathrm{E}+00$ & $0.00 \mathrm{E}+00$ & $0.00 \mathrm{E}+00$ & $0.00 \mathrm{E}+00$ & $0.00 \mathrm{E}+00$ & $0.00 \mathrm{E}+00$ & $0.00 \mathrm{E}+00$ & $0.00 \mathrm{E}+00$ & $0.00 \mathrm{E}+00$ & $0.00 \mathrm{E}+00$ & $0.00 \mathrm{E}+00$ & $0.00 \mathrm{E}+00$ & $0.00 \mathrm{E}+00$ & $0.00 \mathrm{E}+00$ & $0.00 E+00$ \\
\hline GD156 & $3.80 \mathrm{E}-04$ & 4.26E-04 & $4.85 \mathrm{E}-04$ & $5.41 \mathrm{E}-04$ & $5.91 \mathrm{E}-04$ & $6.31 \mathrm{E}-04$ & $6.59 \mathrm{E}-04$ & $6.76 \mathrm{E}-04$ & $6.80 \mathrm{E}-04$ & $6.72 \mathrm{E}-04$ & $6.51 \mathrm{E}-04$ & $6.18 \mathrm{E}-04$ & $5.76 \mathrm{E}-04$ & $5.24 \mathrm{E}-04$ & 4.66E-04 & $4.03 \mathrm{E}-04$ & $3.39 \mathrm{E}-04$ & $2.82 \mathrm{E}-04$ \\
\hline GD157 & $1.70 \mathrm{E}-04$ & 1.82E-04 & 1.99E-04 & 2.15E-04 & $2.29 \mathrm{E}-04$ & $2.40 \mathrm{E}-04$ & $2.47 \mathrm{E}-04$ & $2.51 \mathrm{E}-04$ & $2.52 \mathrm{E}-04$ & $2.50 \mathrm{E}-04$ & $2.45 \mathrm{E}-04$ & $2.36 \mathrm{E}-04$ & 2.25E-04 & 2.10E-04 & $1.93 \mathrm{E}-04$ & $1.74 \mathrm{E}-04$ & $1.53 \mathrm{E}-04$ & $1.34 \mathrm{E}-04$ \\
\hline GD158 & $1.41 \mathrm{E}-04$ & $1.59 \mathrm{E}-04$ & $1.82 \mathrm{E}-04$ & $2.05 \mathrm{E}-04$ & $2.25 \mathrm{E}-04$ & $2.41 \mathrm{E}-04$ & $2.52 \mathrm{E}-04$ & $2.59 \mathrm{E}-04$ & $2.60 \mathrm{E}-04$ & $2.57 \mathrm{E}-04$ & $2.49 \mathrm{E}-04$ & $2.36 \mathrm{E}-04$ & 2.19E-04 & $1.98 \mathrm{E}-04$ & $1.75 \mathrm{E}-04$ & $1.50 \mathrm{E}-04$ & $1.25 \mathrm{E}-04$ & $1.03 \mathrm{E}-04$ \\
\hline
\end{tabular}




\begin{tabular}{|c|c|c|c|c|c|c|c|c|c|c|c|c|c|c|c|c|c|c|}
\hline TB159 & $00=0$ & $00=0$ & 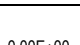 & 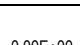 & $00=0$ & $00=0$ & 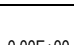 & 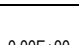 & $00=0$ & 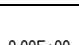 & $x_{00}$ & $00=0$ & $00=0$ & $00=0$ & 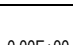 & $00=0$ & $00=$ & 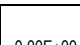 \\
\hline GD160 & $258 E-05$ & $285 E-05$ & DOE-05 & $355 E-05$ & $385--05$ & $409 E-05$ & $426=-05$ & $433 E-05$ & $4395-05$ & $433 E-05$ & $4,21 E_{-05}$ & $401=05$ & $375 E-05$ & $344 E-05$ & $308 E-05$ & $260=-05$ & $28 E-05$ & $192 E-05$ \\
\hline TB160 & $3.83 E-34$ & $4.87 E-34$ & $6.14 \mathrm{E}-34$ & $\begin{array}{l}7.42 E-34 \\
\end{array}$ & $8.60 \mathrm{E}-34$ & $9.60 \mathrm{E}-34$ & $1.03 E-33$ & $1.08 E-33$ & $1.09 E-33$ & $1.07 E-33$ & $2 E-33$ & $9.35 \mathrm{E}-34$ & $8.31 E-34$ & $7.10 E-34$ & $5.82 E-34$ & $4.54 E-34$ & $3.34 E-34$ & $2.33 E-34$ \\
\hline
\end{tabular}


Table A-2j. Composition (grams) in 2-inch fuel segment: ORIGEN calculation results for Pin193045, decayed to 3/11/2011.

\begin{tabular}{|c|c|c|c|c|c|c|c|c|c|c|c|c|c|c|c|c|c|c|}
\hline Position: & 1 & 3 & 5 & 7 & 9 & 11 & 13 & 15 & 17 & 19 & 21 & 23 & 25 & 27 & 29 & 31 & 33 & 35 \\
\hline DY160 & $3.68 \mathrm{E}-06$ & $4.65 \mathrm{E}-06$ & $5.80 \mathrm{E}-06$ & $6.95 \mathrm{E}-06$ & $8.01 \mathrm{E}-06$ & $8.88 \mathrm{E}-06$ & $9.53 \mathrm{E}-06$ & $9.91 \mathrm{E}-06$ & $1.00 \mathrm{E}-05$ & $9.81 \mathrm{E}-06$ & $9.34 \mathrm{E}-06$ & $8.62 \mathrm{E}-06$ & $7.70 \mathrm{E}-06$ & $6.63 \mathrm{E}-06$ & $5.47 \mathrm{E}-06$ & $4.31 \mathrm{E}-06$ & $3.20 \mathrm{E}-06$ & $2.25 \mathrm{E}-06$ \\
\hline DY161 & 1.11E-05 & 1.23E-05 & 1.39E-05 & $1.54 \mathrm{E}-05$ & $1.66 \mathrm{E}-05$ & $1.77 \mathrm{E}-05$ & $1.84 \mathrm{E}-05$ & $1.88 \mathrm{E}-05$ & $1.89 \mathrm{E}-05$ & $1.87 \mathrm{E}-05$ & $1.82 \mathrm{E}-05$ & 1.73E-05 & 1.62E-05 & $1.49 \mathrm{E}-05$ & $1.34 \mathrm{E}-05$ & 1.17E-05 & $9.95 \mathrm{E}-06$ & $8.35 \mathrm{E}-06$ \\
\hline DY162 & $8.12 \mathrm{E}-06$ & $9.26 \mathrm{E}-06$ & $1.06 \mathrm{E}-05$ & 1.19E-05 & $1.31 \mathrm{E}-05$ & $1.40 \mathrm{E}-05$ & 1.46E-05 & 1.50E-05 & $1.51 \mathrm{E}-05$ & 1.49E-05 & $1.44 \mathrm{E}-05$ & $1.37 \mathrm{E}-05$ & 1.27E-05 & $1.15 \mathrm{E}-05$ & $1.02 \mathrm{E}-05$ & $8.77 \mathrm{E}-06$ & $7.30 \mathrm{E}-06$ & $5.95 \mathrm{E}-06$ \\
\hline DY163 & $3.38 \mathrm{E}-06$ & $3.89 \mathrm{E}-06$ & 4.47E-06 & $5.01 \mathrm{E}-06$ & $5.49 \mathrm{E}-06$ & $5.87 \mathrm{E}-06$ & $6.15 \mathrm{E}-06$ & $6.31 \mathrm{E}-06$ & $6.35 \mathrm{E}-06$ & $6.27 \mathrm{E}-06$ & $6.06 \mathrm{E}-06$ & $5.75 \mathrm{E}-06$ & $5.35 \mathrm{E}-06$ & $4.86 \mathrm{E}-06$ & $4.30 \mathrm{E}-06$ & $3.71 \mathrm{E}-06$ & $3.09 \mathrm{E}-06$ & $2.49 \mathrm{E}-06$ \\
\hline DY164 & $1.92 \mathrm{E}-06$ & $2.20 \mathrm{E}-06$ & $2.53 \mathrm{E}-06$ & $2.83 \mathrm{E}-06$ & $3.10 \mathrm{E}-06$ & $3.31 \mathrm{E}-06$ & $3.46 \mathrm{E}-06$ & 3.55E-06 & $3.58 \mathrm{E}-06$ & $3.53 \mathrm{E}-06$ & $3.42 \mathrm{E}-06$ & $3.24 \mathrm{E}-06$ & $3.02 \mathrm{E}-06$ & $2.74 \mathrm{E}-06$ & $2.43 \mathrm{E}-06$ & $2.10 \mathrm{E}-06$ & $1.75 \mathrm{E}-06$ & $1.41 \mathrm{E}-06$ \\
\hline H0165 & $9.59 \mathrm{E}-07$ & 1.09E-06 & $1.24 \mathrm{E}-06$ & $1.38 \mathrm{E}-06$ & $1.51 \mathrm{E}-06$ & $1.60 \mathrm{E}-06$ & 1.67E-06 & $1.71 \mathrm{E}-06$ & $1.72 \mathrm{E}-06$ & $1.70 \mathrm{E}-06$ & $1.65 \mathrm{E}-06$ & $1.57 \mathrm{E}-06$ & 1.47E-06 & $1.34 \mathrm{E}-06$ & $1.20 \mathrm{E}-06$ & $1.04 \mathrm{E}-06$ & $8.76 \mathrm{E}-07$ & $7.14 \mathrm{E}-07$ \\
\hline ER166 & $6.27 \mathrm{E}-07$ & $7.28 \mathrm{E}-07$ & $8.45 \mathrm{E}-07$ & $9.54 \mathrm{E}-07$ & $1.05 \mathrm{E}-06$ & 1.13E-06 & 1.19E-06 & $1.22 \mathrm{E}-06$ & $1.23 \mathrm{E}-06$ & $1.21 \mathrm{E}-06$ & $1.17 \mathrm{E}-06$ & $1.10 \mathrm{E}-06$ & $1.02 \mathrm{E}-06$ & $9.22 \mathrm{E}-07$ & $8.10 \mathrm{E}-07$ & $6.91 \mathrm{E}-07$ & $5.68 \mathrm{E}-07$ & $4.52 \mathrm{E}-07$ \\
\hline ER167 & $3.02 \mathrm{E}-07$ & $3.44 \mathrm{E}-07$ & $3.90 \mathrm{E}-07$ & $4.33 \mathrm{E}-07$ & $4.69 \mathrm{E}-07$ & $4.99 \mathrm{E}-07$ & $5.19 \mathrm{E}-07$ & $5.31 \mathrm{E}-07$ & $5.34 \mathrm{E}-07$ & $5.28 \mathrm{E}-07$ & $5.13 \mathrm{E}-07$ & $4.89 \mathrm{E}-07$ & 4.58E-07 & $4.20 \mathrm{E}-07$ & $3.77 \mathrm{E}-07$ & 3.29E- 07 & $2.78 \mathrm{E}-07$ & 2.27E-07 \\
\hline ER168 & $2.54 \mathrm{E}-08$ & 3.37E-08 & 4.30E- 08 & $5.22 E-08$ & $6.07 \mathrm{E}-08$ & $6.78 \mathrm{E}-08$ & $7.31 \mathrm{E}-08$ & $7.62 \mathrm{E}-08$ & $7.70 \mathrm{E}-08$ & $7.54 \mathrm{E}-08$ & $7.15 \mathrm{E}-08$ & $6.57 \mathrm{E}-08$ & $5.83 \mathrm{E}-08$ & $4.97 \mathrm{E}-08$ & $4.06 \mathrm{E}-08$ & 3.15E-08 & $2.29 \mathrm{E}-08$ & $1.53 \mathrm{E}-08$ \\
\hline $\begin{array}{l}\text { SUM FPs } \\
\text { isotopes }\end{array}$ & $1.30 \mathrm{E}+00$ & $1.38 \mathrm{E}+00$ & $1.50 \mathrm{E}+00$ & $1.62 E+00$ & $1.71 \mathrm{E}+00$ & $1.79 \mathrm{E}+00$ & $1.84 \mathrm{E}+00$ & $1.87 \mathrm{E}+00$ & $1.88 \mathrm{E}+00$ & $1.86 \mathrm{E}+00$ & $1.83 \mathrm{E}+00$ & $1.77 \mathrm{E}+00$ & $1.68 \mathrm{E}+00$ & $1.58 \mathrm{E}+00$ & $1.46 \mathrm{E}+00$ & $1.31 \mathrm{E}+00$ & 1.16E+00 & $1.03 E+00$ \\
\hline H & $1.05 \mathrm{E}-06$ & $1.11 \mathrm{E}-06$ & $1.21 \mathrm{E}-06$ & $1.30 \mathrm{E}-06$ & $1.38 \mathrm{E}-06$ & $1.44 \mathrm{E}-06$ & $1.48 \mathrm{E}-06$ & $1.51 \mathrm{E}-06$ & $1.51 \mathrm{E}-06$ & $1.50 \mathrm{E}-06$ & $1.47 \mathrm{E}-06$ & $1.42 \mathrm{E}-06$ & $1.36 \mathrm{E}-06$ & $1.27 \mathrm{E}-06$ & 1.18E-06 & $1.06 \mathrm{E}-06$ & $9.41 \mathrm{E}-07$ & $8.36 \mathrm{E}-07$ \\
\hline LI & $1.64 \mathrm{E}-08$ & $1.73 \mathrm{E}-08$ & $1.87 \mathrm{E}-08$ & $2.01 \mathrm{E}-08$ & 2.12E-08 & $2.20 \mathrm{E}-08$ & 2.26E- 08 & $2.30 \mathrm{E}-08$ & $2.31 \mathrm{E}-08$ & 2.29E-08 & $2.25 \mathrm{E}-08$ & 2.18E- 08 & 2.08E-08 & $1.96 \mathrm{E}-08$ & $1.82 \mathrm{E}-08$ & 1.65E-08 & $1.47 \mathrm{E}-08$ & $1.32 \mathrm{E}-08$ \\
\hline GE & $6.84 \mathrm{E}-05$ & $7.27 \mathrm{E}-05$ & $7.89 \mathrm{E}-05$ & $8.48 \mathrm{E}-05$ & $8.98 \mathrm{E}-05$ & $9.36 \mathrm{E}-05$ & $9.63 \mathrm{E}-05$ & $9.78 \mathrm{E}-05$ & $9.82 \mathrm{E}-05$ & $9.74 \mathrm{E}-05$ & $9.55 \mathrm{E}-05$ & $9.24 \mathrm{E}-05$ & $8.82 \mathrm{E}-05$ & $8.29 \mathrm{E}-05$ & $7.66 \mathrm{E}-05$ & $6.94 \mathrm{E}-05$ & $6.16 \mathrm{E}-05$ & $5.47 \mathrm{E}-05$ \\
\hline AS & $2.04 \mathrm{E}-05$ & 2.16E-05 & $2.35 \mathrm{E}-05$ & $2.51 \mathrm{E}-05$ & $2.66 \mathrm{E}-05$ & $2.76 \mathrm{E}-05$ & $2.84 \mathrm{E}-05$ & $2.88 \mathrm{E}-05$ & $2.89 \mathrm{E}-05$ & $2.87 \mathrm{E}-05$ & $2.82 \mathrm{E}-05$ & $2.73 \mathrm{E}-05$ & $2.61 \mathrm{E}-05$ & $2.46 \mathrm{E}-05$ & $2.28 \mathrm{E}-05$ & 2.07E-05 & $1.84 \mathrm{E}-05$ & 1.64E-05 \\
\hline SE & $2.67 \mathrm{E}-03$ & $2.83 \mathrm{E}-03$ & $3.07 \mathrm{E}-03$ & $3.29 \mathrm{E}-03$ & $3.48 \mathrm{E}-03$ & $3.63 \mathrm{E}-03$ & $3.73 \mathrm{E}-03$ & $3.79 \mathrm{E}-03$ & $3.81 \mathrm{E}-03$ & $3.78 \mathrm{E}-03$ & $3.70 \mathrm{E}-03$ & $3.58 \mathrm{E}-03$ & $3.42 \mathrm{E}-03$ & $3.22 \mathrm{E}-03$ & 2.97E-03 & $2.69 \mathrm{E}-03$ & $2.39 \mathrm{E}-03$ & 2.13E-03 \\
\hline BR & $9.94 \mathrm{E}-04$ & $1.05 \mathrm{E}-03$ & 1.13E- 03 & $1.21 \mathrm{E}-03$ & $1.28 \mathrm{E}-03$ & $1.33 \mathrm{E}-03$ & 1.37E-03 & $1.39 \mathrm{E}-03$ & $1.39 \mathrm{E}-03$ & $1.38 \mathrm{E}-03$ & $1.35 \mathrm{E}-03$ & 1.31E-03 & $1.26 \mathrm{E}-03$ & 1.19E-03 & 1.10E-03 & $1.00 \mathrm{E}-03$ & $8.93 \mathrm{E}-04$ & $8.00 \mathrm{E}-04$ \\
\hline $\mathrm{KR}$ & $1.67 \mathrm{E}-02$ & 1.76E-02 & $1.91 \mathrm{E}-02$ & 2.05E-02 & $2.17 \mathrm{E}-02$ & $2.26 \mathrm{E}-02$ & 2.33E-02 & 2.37E-02 & $2.38 \mathrm{E}-02$ & $2.36 \mathrm{E}-02$ & $2.31 \mathrm{E}-02$ & 2.24E-02 & 2.13E-02 & 2.01E-02 & $1.85 \mathrm{E}-02$ & 1.68E-02 & 1.49E-02 & 1.33E-02 \\
\hline RB & $1.69 \mathrm{E}-02$ & $1.78 \mathrm{E}-02$ & $1.93 \mathrm{E}-02$ & $2.07 \mathrm{E}-02$ & 2.19E-02 & $2.28 \mathrm{E}-02$ & 2.34E-02 & 2.38E-02 & $2.39 \mathrm{E}-02$ & 2.37E-02 & $2.32 \mathrm{E}-02$ & $2.25 \mathrm{E}-02$ & $2.15 \mathrm{E}-02$ & $2.02 E-02$ & $1.87 \mathrm{E}-02$ & 1.69E-02 & $1.51 \mathrm{E}-02$ & $1.35 \mathrm{E}-02$ \\
\hline$S R$ & $3.26 \mathrm{E}-02$ & $3.43 \mathrm{E}-02$ & $3.72 \mathrm{E}-02$ & $3.99 \mathrm{E}-02$ & $4.22 \mathrm{E}-02$ & $4.40 \mathrm{E}-02$ & 4.53E-02 & 4.60E-02 & $4.61 \mathrm{E}-02$ & $4.58 \mathrm{E}-02$ & 4.49E-02 & $4.35 \mathrm{E}-02$ & 4.15E-02 & $3.90 \mathrm{E}-02$ & $3.61 \mathrm{E}-02$ & $3.27 \mathrm{E}-02$ & $2.91 \mathrm{E}-02$ & $2.60 \mathrm{E}-02$ \\
\hline Y & $2.12 \mathrm{E}-02$ & $2.24 \mathrm{E}-02$ & 2.43E- 02 & $2.60 \mathrm{E}-02$ & $2.75 \mathrm{E}-02$ & $2.87 \mathrm{E}-02$ & 2.95E-02 & $3.00 \mathrm{E}-02$ & $3.01 \mathrm{E}-02$ & $2.98 \mathrm{E}-02$ & $2.93 \mathrm{E}-02$ & 2.83E-02 & $2.71 \mathrm{E}-02$ & $2.55 \mathrm{E}-02$ & $2.35 \mathrm{E}-02$ & 2.13E-02 & $1.90 \mathrm{E}-02$ & $1.70 \mathrm{E}-02$ \\
\hline$Z R$ & $1.59 \mathrm{E}-01$ & 1.68E-01 & 1.83E-01 & $1.96 \mathrm{E}-01$ & $2.08 \mathrm{E}-01$ & $2.16 \mathrm{E}-01$ & 2.23E-01 & $2.26 \mathrm{E}-01$ & $2.27 \mathrm{E}-01$ & $2.25 \mathrm{E}-01$ & $2.21 \mathrm{E}-01$ & 2.14E-01 & $2.04 \mathrm{E}-01$ & $1.92 \mathrm{E}-01$ & 1.77E-01 & 1.60E-01 & 1.42E-01 & 1.27E-01 \\
\hline
\end{tabular}




\begin{tabular}{|c|c|c|c|c|c|c|c|c|c|c|c|c|c|c|c|c|c|c|}
\hline NB & & & & & & & & & & & & & & & & & & \\
\hline & $3.01 E-07$ & $3.19 \mathrm{E}-07$ & $\begin{array}{l}3.46 \mathrm{E}-07 \\
3\end{array}$ & $3.73 \mathrm{E}-07$ & $3.95 \mathrm{E}-07$ & $4.12 E-07$ & $4.25 \mathrm{E}-07$ & $4.32 E-07$ & $4.33 \mathrm{E}-07$ & 4.30E -07 & $4.21 E-07$ & $4.07 E-07$ & $3.88 \mathrm{E}-07$ & $3.64 \mathrm{E}-07$ & $3.36 \mathrm{E}-07$ & $3.03 \mathrm{E}-07$ & $2.69 \mathrm{E}-07$ & $2.40 \mathrm{E}-07$ \\
\hline мо & $1.30 \mathrm{E}-0$ & $1.37 \mathrm{E}-01$ & $1.49 \mathrm{E}-01$ & $1.60 \mathrm{E}-01$ & $1.70 \mathrm{E}-01$ & $1.77 \mathrm{E}-01$ & $1.83 \mathrm{E}-01$ & $1.86 \mathrm{E}-01$ & $1.86 \mathrm{E}-01$ & $1.85 E-01$ & $1.81 E-01$ & $1.75 E-01$ & $1.67 \mathrm{E}-01$ & $1.57 \mathrm{E}-01$ & $1.45 E-01$ & $1.31 \mathrm{E}-01$ & 1.16E-01 & $1.03 \mathrm{E}-01$ \\
\hline TC & $3.04 E-02$ & $3.22 \mathrm{E}-02$ & $3.49 \mathrm{E}-02$ & $3.74 E-02$ & $3.96 \mathrm{E}-02$ & $4.13 \mathrm{E}-02$ & $4.24 \mathrm{E}-02$ & $4.31 \mathrm{E}-02$ & $4.32 \mathrm{E}-02$ & 4.29E-02 & $4.21 E-02$ & $4.07 E-02$ & $3.89 \mathrm{E}-02$ & $3.66 \mathrm{E}-02$ & $3.38 \mathrm{E}-02$ & $3.07 E-02$ & $2.73 \mathrm{E}-02$ & $2.43 \mathrm{E}-02$ \\
\hline $\mathrm{RU}$ & 7.27E-02 & 77E-02 & $\mathrm{E}-02$ & 20E-02 & $1.78 E-02$ & $1.02 E-01$ & $6 \mathrm{E}-01$ & $1.07 E-01$ & $1.08 \mathrm{E}-01$ & $1.07 E-01$ & $1.05 E-01$ & $1.01 \mathrm{E}-01$ & $9.60 \mathrm{E}-02$ & $8.97 \mathrm{E}-02$ & $8.24 \mathrm{E}-02$ & 7.40E-02 & & 0.145 \\
\hline
\end{tabular}


Table A-2k. Composition (grams) in 2-inch fuel segment: ORIGEN calculation results for Pin193045, decayed to 3/11/2011.

\begin{tabular}{|c|c|c|c|c|c|c|c|c|c|c|c|c|c|c|c|c|c|c|}
\hline Position: & 1 & 3 & 5 & 7 & 9 & 11 & 13 & 15 & 17 & 19 & 21 & 23 & 25 & 27 & 29 & 31 & 33 & 35 \\
\hline $\mathrm{RH}$ & $1.95 \mathrm{E}-02$ & $2.08 \mathrm{E}-02$ & $2.27 \mathrm{E}-02$ & $2.44 \mathrm{E}-02$ & $2.59 \mathrm{E}-02$ & $2.70 \mathrm{E}-02$ & $2.78 \mathrm{E}-02$ & $2.83 \mathrm{E}-02$ & $2.84 \mathrm{E}-02$ & $2.82 \mathrm{E}-02$ & $2.76 \mathrm{E}-02$ & $2.67 \mathrm{E}-02$ & $2.54 \mathrm{E}-02$ & 2.39E-02 & 2.20E-02 & $1.98 \mathrm{E}-02$ & $1.76 \mathrm{E}-02$ & $1.55 \mathrm{E}-02$ \\
\hline PD & $2.19 \mathrm{E}-02$ & $2.41 \mathrm{E}-02$ & $2.70 \mathrm{E}-02$ & $2.97 \mathrm{E}-02$ & $3.21 \mathrm{E}-02$ & $3.40 \mathrm{E}-02$ & $3.53 \mathrm{E}-02$ & $3.60 \mathrm{E}-02$ & $3.62 \mathrm{E}-02$ & $3.58 \mathrm{E}-02$ & $3.49 \mathrm{E}-02$ & $3.34 \mathrm{E}-02$ & $3.14 \mathrm{E}-02$ & $2.89 \mathrm{E}-02$ & 2.61E-02 & $2.29 \mathrm{E}-02$ & $1.97 \mathrm{E}-02$ & 1.67E-02 \\
\hline AG & $1.59 \mathrm{E}-03$ & $1.74 \mathrm{E}-03$ & $1.94 \mathrm{E}-03$ & $2.13 \mathrm{E}-03$ & $2.30 \mathrm{E}-03$ & $2.43 \mathrm{E}-03$ & $2.52 \mathrm{E}-03$ & $2.58 \mathrm{E}-03$ & $2.59 \mathrm{E}-03$ & $2.56 \mathrm{E}-03$ & $2.50 \mathrm{E}-03$ & $2.39 \mathrm{E}-03$ & $2.25 \mathrm{E}-03$ & $2.07 \mathrm{E}-03$ & $1.87 \mathrm{E}-03$ & $1.65 \mathrm{E}-03$ & 1.42E-03 & $1.21 \mathrm{E}-03$ \\
\hline$C D$ & $3.78 \mathrm{E}-03$ & 4.17E- -03 & 4.62E-03 & $5.01 \mathrm{E}-03$ & $5.35 \mathrm{E}-03$ & $5.61 \mathrm{E}-03$ & $5.79 \mathrm{E}-03$ & $5.89 \mathrm{E}-03$ & $5.92 \mathrm{E}-03$ & $5.87 \mathrm{E}-03$ & $5.74 \mathrm{E}-03$ & $5.53 \mathrm{E}-03$ & $5.25 \mathrm{E}-03$ & $4.90 \mathrm{E}-03$ & 4.48E-03 & $4.01 \mathrm{E}-03$ & $3.50 \mathrm{E}-03$ & $2.99 \mathrm{E}-03$ \\
\hline $\mathbb{N}$ & $5.20 \mathrm{E}-04$ & $5.52 \mathrm{E}-04$ & $5.86 \mathrm{E}-04$ & $6.13 \mathrm{E}-04$ & $6.34 \mathrm{E}-04$ & $6.49 \mathrm{E}-04$ & $6.59 \mathrm{E}-04$ & $6.64 \mathrm{E}-04$ & $6.65 \mathrm{E}-04$ & $6.63 \mathrm{E}-04$ & $6.56 \mathrm{E}-04$ & $6.44 \mathrm{E}-04$ & $6.28 \mathrm{E}-04$ & $6.05 \mathrm{E}-04$ & $5.75 \mathrm{E}-04$ & $5.38 \mathrm{E}-04$ & $4.91 \mathrm{E}-04$ & 4.40E-04 \\
\hline SN & $6.42 \mathrm{E}-03$ & $7.02 \mathrm{E}-03$ & $7.73 \mathrm{E}-03$ & $8.37 \mathrm{E}-03$ & $8.91 \mathrm{E}-03$ & 9.33E-03 & $9.61 \mathrm{E}-03$ & $9.78 \mathrm{E}-03$ & $9.82 \mathrm{E}-03$ & $9.73 \mathrm{E}-03$ & $9.53 \mathrm{E}-03$ & $9.20 \mathrm{E}-03$ & $8.75 \mathrm{E}-03$ & $8.19 \mathrm{E}-03$ & $7.51 \mathrm{E}-03$ & $6.75 \mathrm{E}-03$ & $5.90 \mathrm{E}-03$ & $5.10 \mathrm{E}-03$ \\
\hline SB & $1.52 \mathrm{E}-03$ & $1.65 \mathrm{E}-03$ & $1.81 \mathrm{E}-03$ & $1.95 \mathrm{E}-03$ & $2.06 \mathrm{E}-03$ & $2.15 \mathrm{E}-03$ & $2.21 \mathrm{E}-03$ & $2.24 \mathrm{E}-03$ & $2.25 \mathrm{E}-03$ & $2.24 \mathrm{E}-03$ & 2.19E-03 & $2.12 \mathrm{E}-03$ & $2.03 \mathrm{E}-03$ & $1.91 \mathrm{E}-03$ & $1.76 \mathrm{E}-03$ & $1.59 \mathrm{E}-03$ & $1.40 \mathrm{E}-03$ & $1.22 \mathrm{E}-03$ \\
\hline $\mathrm{TE}$ & $2.12 \mathrm{E}-02$ & $2.27 \mathrm{E}-02$ & $2.47 \mathrm{E}-02$ & $2.66 \mathrm{E}-02$ & $2.83 \mathrm{E}-02$ & $2.95 \mathrm{E}-02$ & $3.04 \mathrm{E}-02$ & 3.09E-02 & $3.11 \mathrm{E}-02$ & $3.08 \mathrm{E}-02$ & $3.02 \mathrm{E}-02$ & $2.91 \mathrm{E}-02$ & $2.78 \mathrm{E}-02$ & $2.60 \mathrm{E}-02$ & $2.40 \mathrm{E}-02$ & $2.16 \mathrm{E}-02$ & $1.91 \mathrm{E}-02$ & $1.69 \mathrm{E}-02$ \\
\hline 1 & 1.10E-02 & $1.18 \mathrm{E}-02$ & 1.28E-02 & $1.38 \mathrm{E}-02$ & 1.46E-02 & $1.52 \mathrm{E}-02$ & $1.56 \mathrm{E}-02$ & $1.59 \mathrm{E}-02$ & 1.59E-02 & $1.58 \mathrm{E}-02$ & $1.55 \mathrm{E}-02$ & 1.50E-02 & $1.43 \mathrm{E}-02$ & $1.34 \mathrm{E}-02$ & $1.24 \mathrm{E}-02$ & 1.12E- 02 & $9.95 \mathrm{E}-03$ & $8.81 \mathrm{E}-03$ \\
\hline XE & 1.62E-01 & $1.72 \mathrm{E}-01$ & 1.87E-01 & $2.01 \mathrm{E}-01$ & 2.13E-01 & 2.23E-01 & 2.29E-01 & 2.33E-01 & 2.34E-01 & 2.32E-01 & 2.27E-01 & 2.20E-01 & $2.09 \mathrm{E}-01$ & 1.96E-01 & 1.81E-01 & $1.63 \mathrm{E}-01$ & 1.45E-01 & 1.29E-01 \\
\hline CS & $1.21 \mathrm{E}-01$ & $1.28 \mathrm{E}-01$ & 1.40E-01 & $1.50 \mathrm{E}-01$ & $1.59 \mathrm{E}-01$ & $1.66 \mathrm{E}-01$ & 1.71E-01 & $1.73 \mathrm{E}-01$ & $1.74 \mathrm{E}-01$ & 1.73E-01 & 1.69E-01 & 1.64E- 01 & 1.56E-01 & 1.47E-01 & $1.35 \mathrm{E}-01$ & $1.22 \mathrm{E}-01$ & 1.09E-01 & $9.67 \mathrm{E}-02$ \\
\hline $\mathrm{BA}$ & $6.83 \mathrm{E}-02$ & $7.27 \mathrm{E}-02$ & $7.93 \mathrm{E}-02$ & $8.57 \mathrm{E}-02$ & $9.11 \mathrm{E}-02$ & 9.54E-02 & $9.84 \mathrm{E}-02$ & $1.00 \mathrm{E}-01$ & $1.01 \mathrm{E}-01$ & $9.96 \mathrm{E}-02$ & $9.75 \mathrm{E}-02$ & $9.41 \mathrm{E}-02$ & $8.94 \mathrm{E}-02$ & $8.36 \mathrm{E}-02$ & $7.68 \mathrm{E}-02$ & $6.91 \mathrm{E}-02$ & $6.10 \mathrm{E}-02$ & $5.40 \mathrm{E}-02$ \\
\hline LA & $4.76 \mathrm{E}-02$ & $5.05 \mathrm{E}-02$ & $5.48 \mathrm{E}-02$ & $5.90 \mathrm{E}-02$ & $6.25 \mathrm{E}-02$ & $6.52 \mathrm{E}-02$ & $6.71 \mathrm{E}-02$ & $6.82 \mathrm{E}-02$ & $6.85 \mathrm{E}-02$ & $6.79 \mathrm{E}-02$ & $6.66 \mathrm{E}-02$ & $6.44 \mathrm{E}-02$ & $6.14 \mathrm{E}-02$ & $5.76 \mathrm{E}-02$ & $5.32 \mathrm{E}-02$ & $4.80 \mathrm{E}-02$ & $4.26 \mathrm{E}-02$ & $3.79 \mathrm{E}-02$ \\
\hline CE & $8.92 \mathrm{E}-02$ & $9.45 \mathrm{E}-02$ & $1.03 \mathrm{E}-01$ & $1.10 \mathrm{E}-01$ & $1.17 \mathrm{E}-01$ & 1.22E-01 & $1.26 \mathrm{E}-01$ & 1.28E-01 & $1.28 \mathrm{E}-01$ & $1.27 \mathrm{E}-01$ & $1.25 \mathrm{E}-01$ & $1.21 \mathrm{E}-01$ & $1.15 \mathrm{E}-01$ & $1.08 \mathrm{E}-01$ & $9.95 \mathrm{E}-02$ & $8.99 \mathrm{E}-02$ & $7.98 \mathrm{E}-02$ & $7.10 \mathrm{E}-02$ \\
\hline PR & 4.51E-02 & 4.77E-02 & $5.18 \mathrm{E}-02$ & $5.57 \mathrm{E}-02$ & 5.89E-02 & $6.15 \mathrm{E}-02$ & $6.32 \mathrm{E}-02$ & $6.42 \mathrm{E}-02$ & $6.45 \mathrm{E}-02$ & $6.40 \mathrm{E}-02$ & $6.27 \mathrm{E}-02$ & 6.07E-02 & $5.79 \mathrm{E}-02$ & 5.44E-02 & $5.02 \mathrm{E}-02$ & $4.54 \mathrm{E}-02$ & $4.03 E-02$ & 3.60E-02 \\
\hline ND & $1.57 \mathrm{E}-01$ & $1.66 \mathrm{E}-01$ & 1.81E-01 & $1.95 \mathrm{E}-01$ & $2.06 \mathrm{E}-01$ & $2.15 \mathrm{E}-01$ & 2.21E-01 & 2.25E-01 & 2.26E-01 & 2.24E-01 & 2.20E-01 & 2.12E-01 & 2.03E-01 & $1.90 \mathrm{E}-01$ & $1.75 \mathrm{E}-01$ & $1.59 \mathrm{E}-01$ & 1.41E-01 & 1.25E-01 \\
\hline PM & $7.20 \mathrm{E}-05$ & $7.46 \mathrm{E}-05$ & $7.93 E-05$ & $8.36 \mathrm{E}-05$ & 8.72E-05 & $8.98 \mathrm{E}-05$ & $9.16 \mathrm{E}-05$ & $9.26 \mathrm{E}-05$ & $9.29 \mathrm{E}-05$ & $9.24 \mathrm{E}-05$ & 9.11E-05 & $8.91 \mathrm{E}-05$ & $8.61 \mathrm{E}-05$ & $8.23 \mathrm{E}-05$ & $7.74 \mathrm{E}-05$ & $7.16 \mathrm{E}-05$ & $6.51 \mathrm{E}-05$ & 5.95E-05 \\
\hline SM & $3.55 \mathrm{E}-02$ & $3.79 \mathrm{E}-02$ & 4.14E-02 & 4.47E-02 & 4.75E-02 & 4.97E-02 & $5.13 \mathrm{E}-02$ & $5.21 \mathrm{E}-02$ & $5.23 \mathrm{E}-02$ & $5.19 \mathrm{E}-02$ & $5.08 \mathrm{E}-02$ & $4.90 \mathrm{E}-02$ & 4.66E-02 & 4.37E-02 & $4.01 \mathrm{E}-02$ & $3.61 \mathrm{E}-02$ & $3.18 \mathrm{E}-02$ & $2.81 \mathrm{E}-02$ \\
\hline EU & $2.27 \mathrm{E}-03$ & $2.41 \mathrm{E}-03$ & 2.62E-03 & $2.81 \mathrm{E}-03$ & $2.97 \mathrm{E}-03$ & $3.10 \mathrm{E}-03$ & $3.19 \mathrm{E}-03$ & 3.23E- 03 & $3.25 \mathrm{E}-03$ & 3.22E-03 & $3.16 \mathrm{E}-03$ & $3.06 \mathrm{E}-03$ & $2.92 \mathrm{E}-03$ & $2.75 \mathrm{E}-03$ & $2.54 \mathrm{E}-03$ & $2.31 \mathrm{E}-03$ & 2.05E-03 & 1.82E-03 \\
\hline$G D$ & $1.41 \mathrm{E}-03$ & $1.57 \mathrm{E}-03$ & $1.77 \mathrm{E}-03$ & $1.97 \mathrm{E}-03$ & $2.14 \mathrm{E}-03$ & $2.28 \mathrm{E}-03$ & $2.38 \mathrm{E}-03$ & $2.43 \mathrm{E}-03$ & $2.45 \mathrm{E}-03$ & $2.42 \mathrm{E}-03$ & $2.35 \mathrm{E}-03$ & $2.24 \mathrm{E}-03$ & $2.09 \mathrm{E}-03$ & $1.91 \mathrm{E}-03$ & $1.71 \mathrm{E}-03$ & $1.48 \mathrm{E}-03$ & $1.26 \mathrm{E}-03$ & $1.06 \mathrm{E}-03$ \\
\hline TB & 4.76E-05 & $5.24 \mathrm{E}-05$ & $5.87 \mathrm{E}-05$ & $6.46 \mathrm{E}-05$ & $6.98 \mathrm{E}-05$ & $7.40 \mathrm{E}-05$ & 7.69E-05 & $7.86 \mathrm{E}-05$ & $7.90 \mathrm{E}-05$ & $7.82 \mathrm{E}-05$ & $7.60 \mathrm{E}-05$ & $7.27 \mathrm{E}-05$ & $6.82 \mathrm{E}-05$ & $6.28 \mathrm{E}-05$ & $5.65 E-05$ & $4.96 \mathrm{E}-05$ & $4.25 \mathrm{E}-05$ & $3.60 \mathrm{E}-05$ \\
\hline
\end{tabular}




\begin{tabular}{|c|c|c|c|c|c|c|c|c|c|c|c|c|c|c|c|c|c|c|}
\hline DY & & & & & & & & & & & & & & & & & & \\
\hline & $2.82 \mathrm{E}-05$ & $3.23 \mathrm{E}-05$ & $3.73 \mathrm{E}-05$ & $4.21 \mathrm{E}-05$ & $4.63 \mathrm{E}-05$ & $4.97 \mathrm{E}-05$ & $5.22 \mathrm{E}-05$ & $5.36 \mathrm{E}-05$ & $5.40 \mathrm{E}-05$ & $5.32 E-05$ & $5.14 \mathrm{E}-05$ & $4.86 \mathrm{E}-05$ & $4.50 \mathrm{E}-05$ & $4.06 E-05$ & $3.58 \mathrm{E}-05$ & $3.06 \mathrm{E}-05$ & $2.53 \mathrm{E}-05$ & $2.05 \mathrm{E}-05$ \\
\hline но & $9.63 \mathrm{E}-07$ & 1.10E-06 & $1.25 \mathrm{E}-06$ & 1.39E-06 & $1.51 \mathrm{E}-06$ & $1.61 \mathrm{E}-06$ & $1.68 E-06$ & $1.72 \mathrm{E}-06$ & $1.73 \mathrm{E}-0$ & $1.71 \mathrm{E}-06$ & $1.66 E-06$ & $1.58 E-06$ & $1.48 \mathrm{E}-06$ & $1.35 E-06$ & $1.21 \mathrm{E}-06$ & $1.05 E-06$ & $8.80 \mathrm{E}-07$ & $7.17 \mathrm{E}-07$ \\
\hline ER & $9.54 \mathrm{E}-07$ & 1.111E-06 & $1.28 \mathrm{E}-06$ & $1.44 \mathrm{E}-06$ & $1.58 \mathrm{E}-06$ & $1.70 \mathrm{E}-06$ & $1.78 \mathrm{E}-06$ & $1.83 \mathrm{E}-06$ & $1.84 \mathrm{E}-06$ & $1.81 \mathrm{E}-06$ & $1.75 E-06$ & $1.66 \mathrm{E}-06$ & $1.54 \mathrm{E}-06$ & $1.39 E-06$ & $1.23 \mathrm{E}-06$ & $1.05 E-06$ & $8.69 \mathrm{E}-07$ & $6.94 \mathrm{E}-07$ \\
\hline $\begin{array}{l}\text { SUM FPs } \\
\text { elementa } \\
\text { a }\end{array}$ & $1.30 \mathrm{E}+00$ & $1.38 \mathrm{E}+00$ & $1.50 \mathrm{E}+00$ & $1.62 E+00$ & $1.71 E++00$ & $1.79 E++00$ & $1.84 \mathrm{E}+00$ & $1.87 \mathrm{E}+00$ & $1.88 \mathrm{E}+00$ & $1.86 \Subset+00$ & $1.83 E+00$ & $1.77 E+00$ & $1.68 E+00$ & $1.58 E+00$ & $1.45 E+00$ & $1.31 E+00$ & 1.1.16 E+00 & $1.03 E+00$ \\
\hline
\end{tabular}


Appendix B

Neutron Radiography 


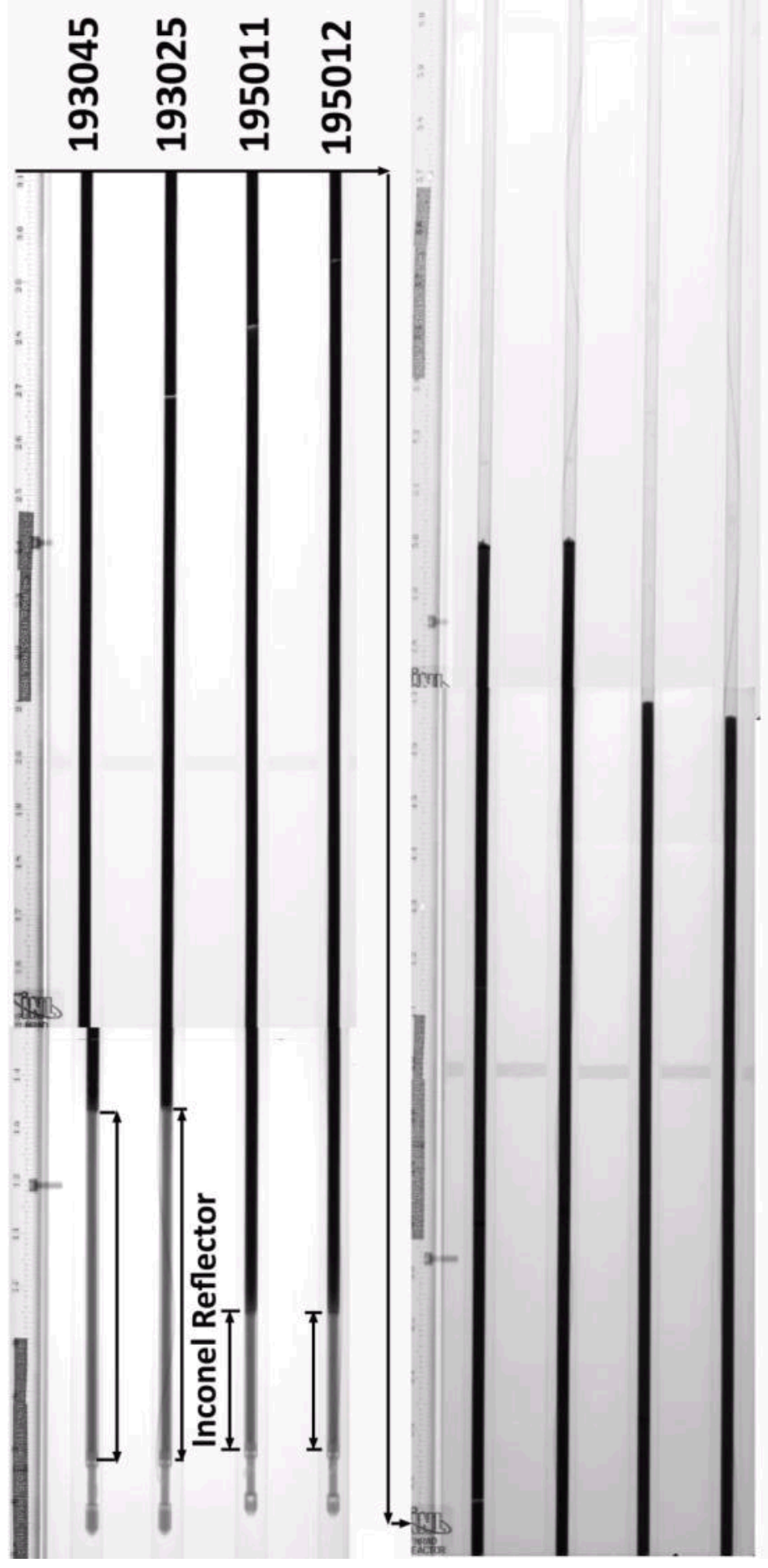


Figure B-1. Thermal neutron radiograph of MFF3 Pins 193065 and 193025 and MFF-5 Pins 195011 and 195012. Note that Pin 193065 shifted between the first and second shots.

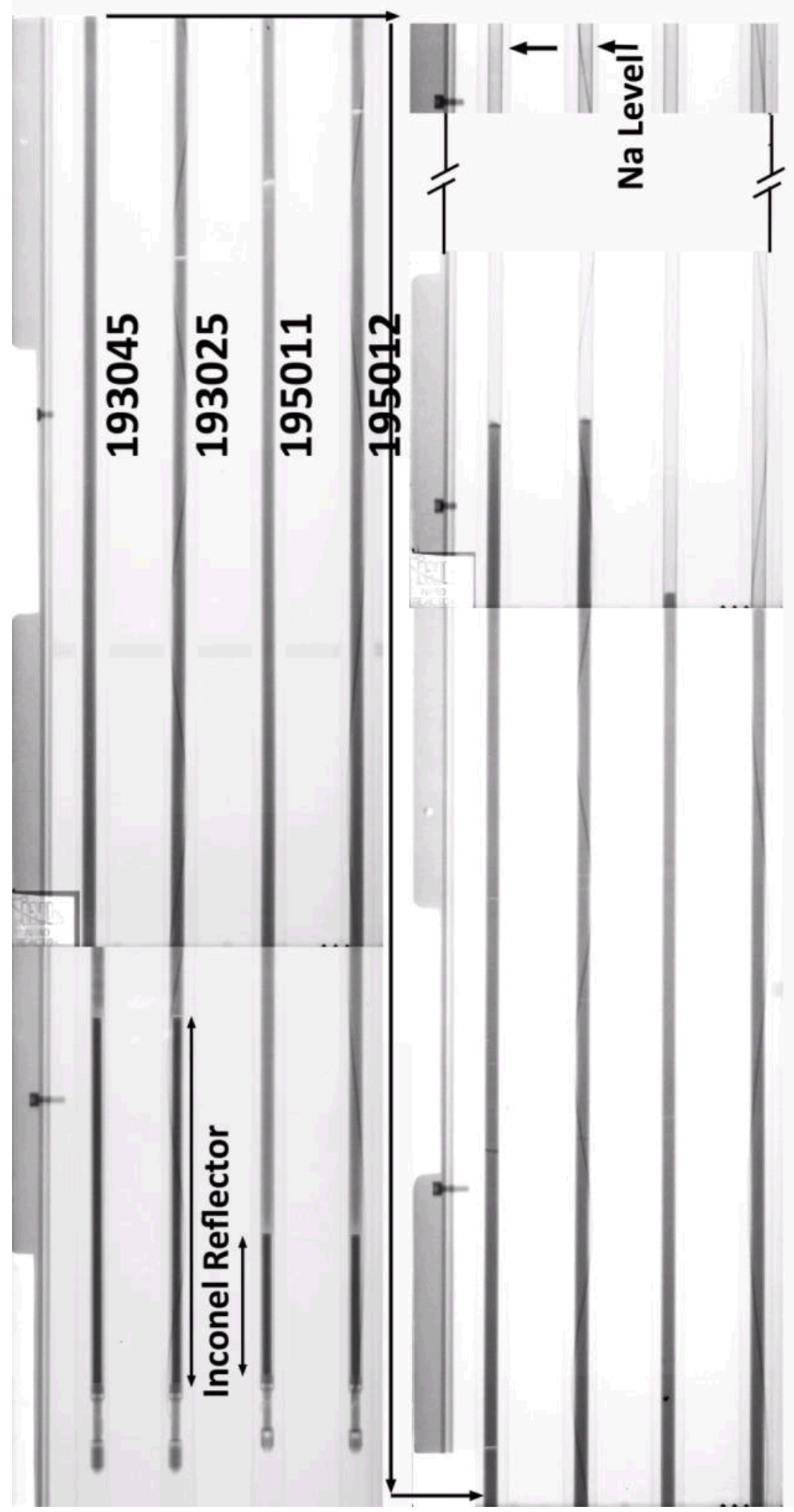

Figure B-2. Epithermal neutron radiograph of MFF3 Pins 193065 and 193025 and MFF-5 Pins 195011 
and 195012. Note that Pin 193065 shifted between the first and second shots. Note that Na level is best seen in epithermal images.

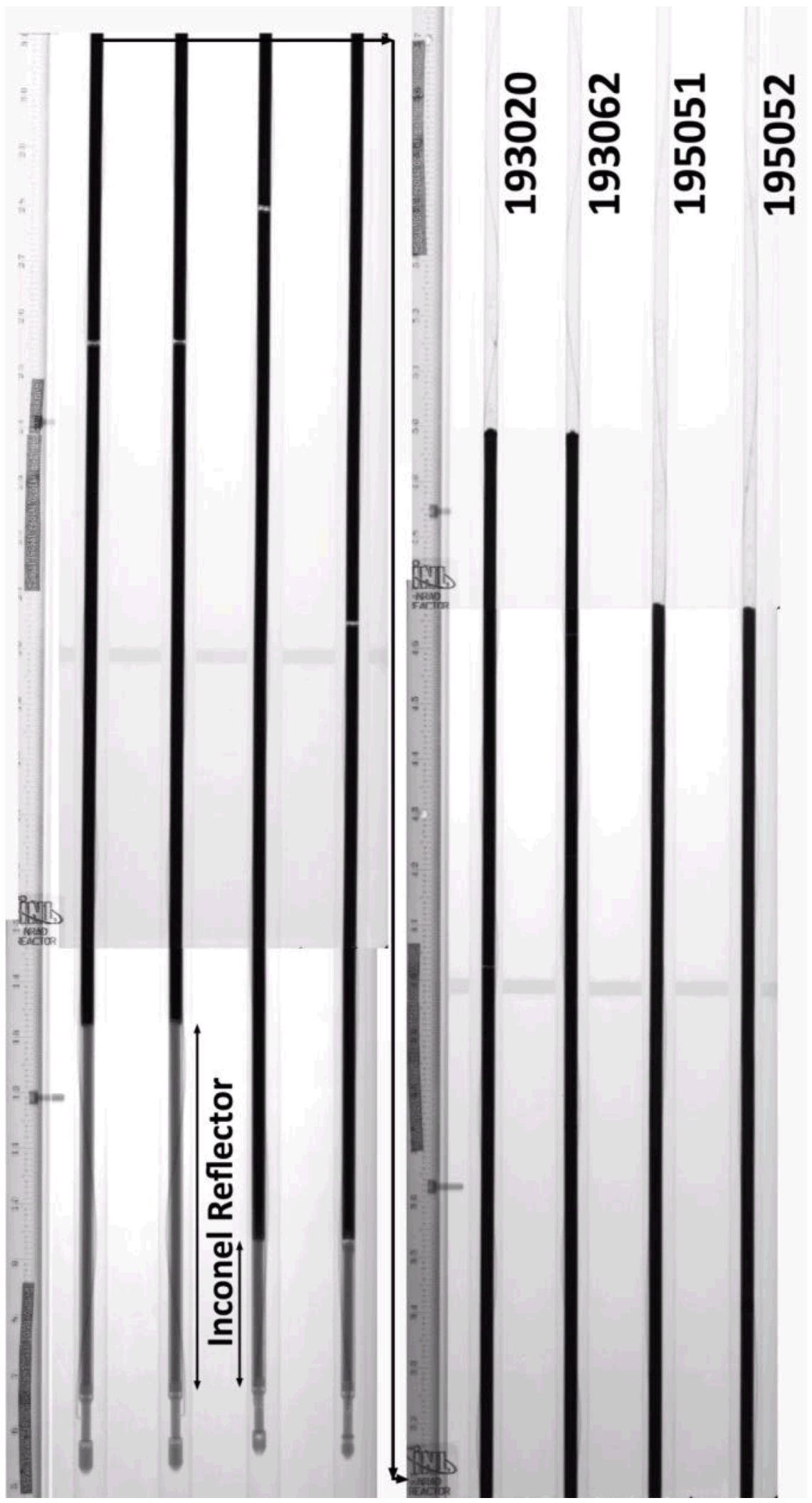


Figure B -3. Thermal neutron radiograph of MFF3 Pins 193020 and 193062 and MFF-5 Pins 195051 and 195052. 


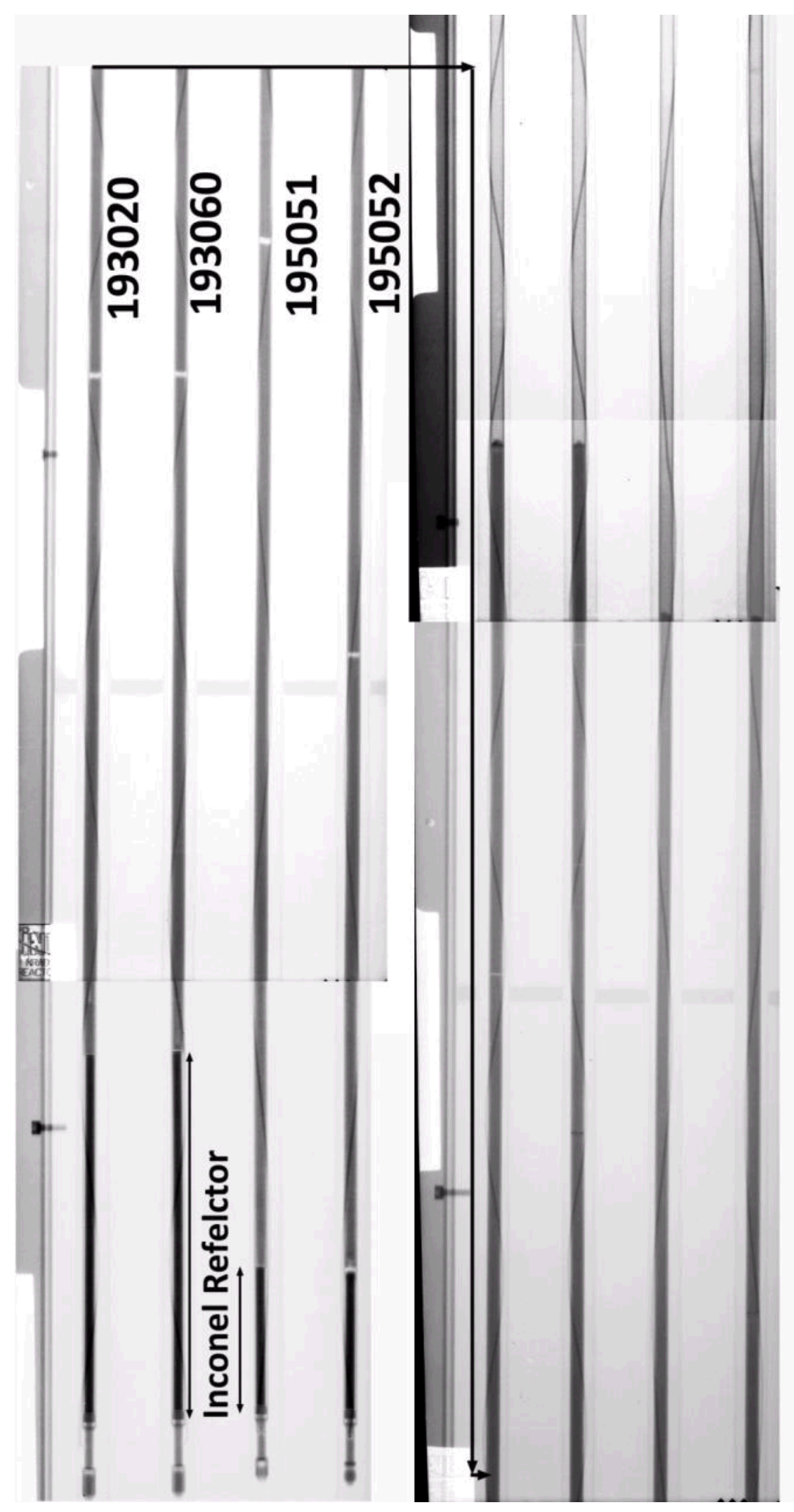

Figure B-4. Thermal neutron radiograph of MFF3 Pins 193020 and 193062 and MFF-5 Pins 195051 and 195052. 


\section{Appendix C}

\section{Precision Gamma Scanning}


cviii 


\section{Appendix C}

\section{Precision Gamma Scanning}

\section{MFF-3 Gamma Scans}

Four MFF-3 pins were scanned for gamma activity and specifically Co-60, Cs-134, and Eu-154 were noted. The scans are shown in Figures C-1 through C-4.

Note that the top of the element is actually at the lower Z-position, on the left-hand-side of the graphs. The Co-60 peaks in the Inconel reflector as expected. In some of the scans the Co-60 seems also to peak above the fuel column. The reason for this is not clear, unless shielding is also responsible, or if there is an interference with the Cs activity.

Usually, the Cs-134 peaks just above the fuel column, in the bond sodium which has been pushed above the fuel as the fuel swelled. It is also a stronger signal there as there is no shielding from the fuel.

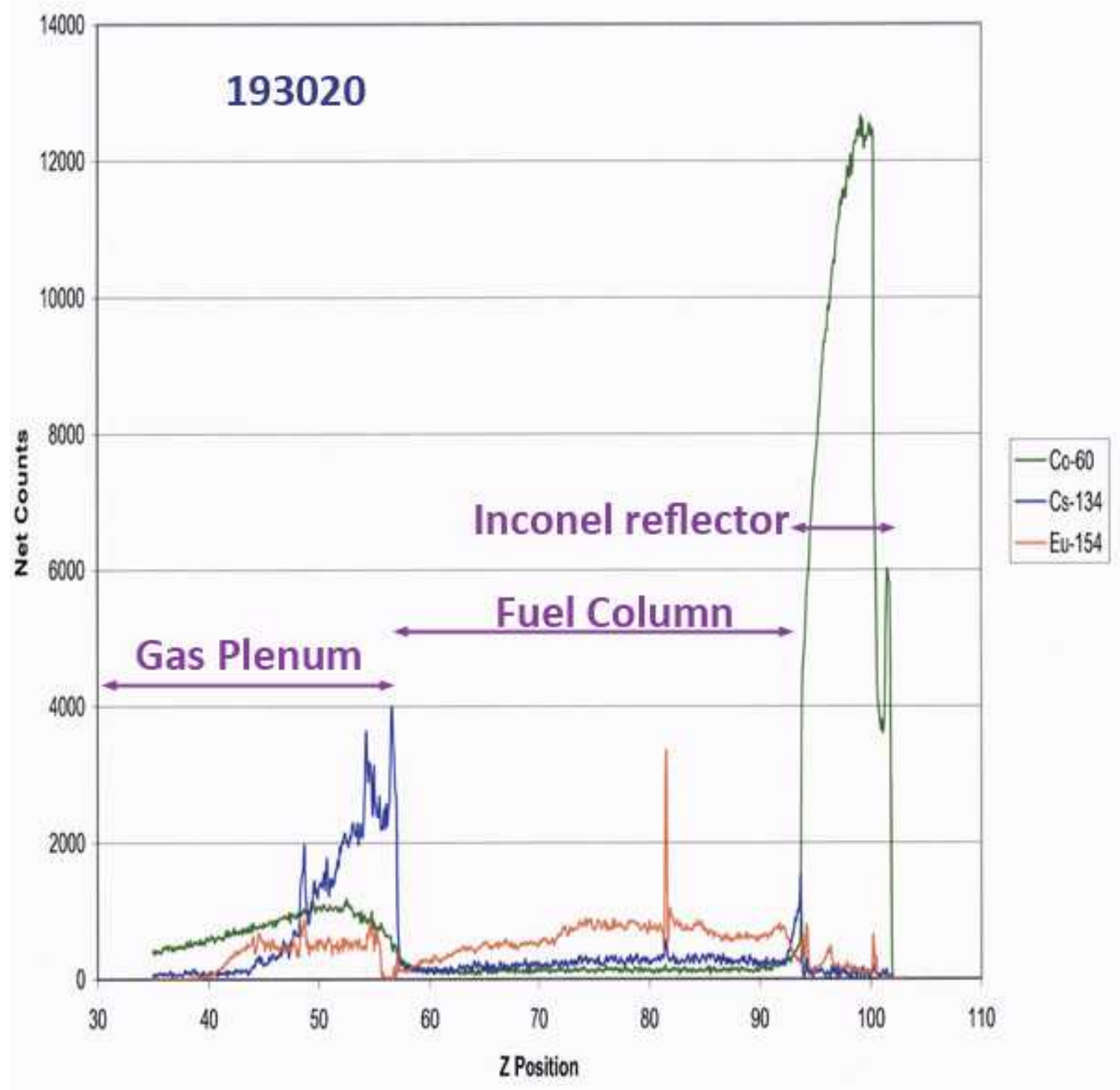


Figure C-1. Gamma scan traces for MFF-3 Pin 193020. Co-60 peaks in Inconel reflector, Cs-134 peaks just above fuel column (lower Z-position is top of pin).

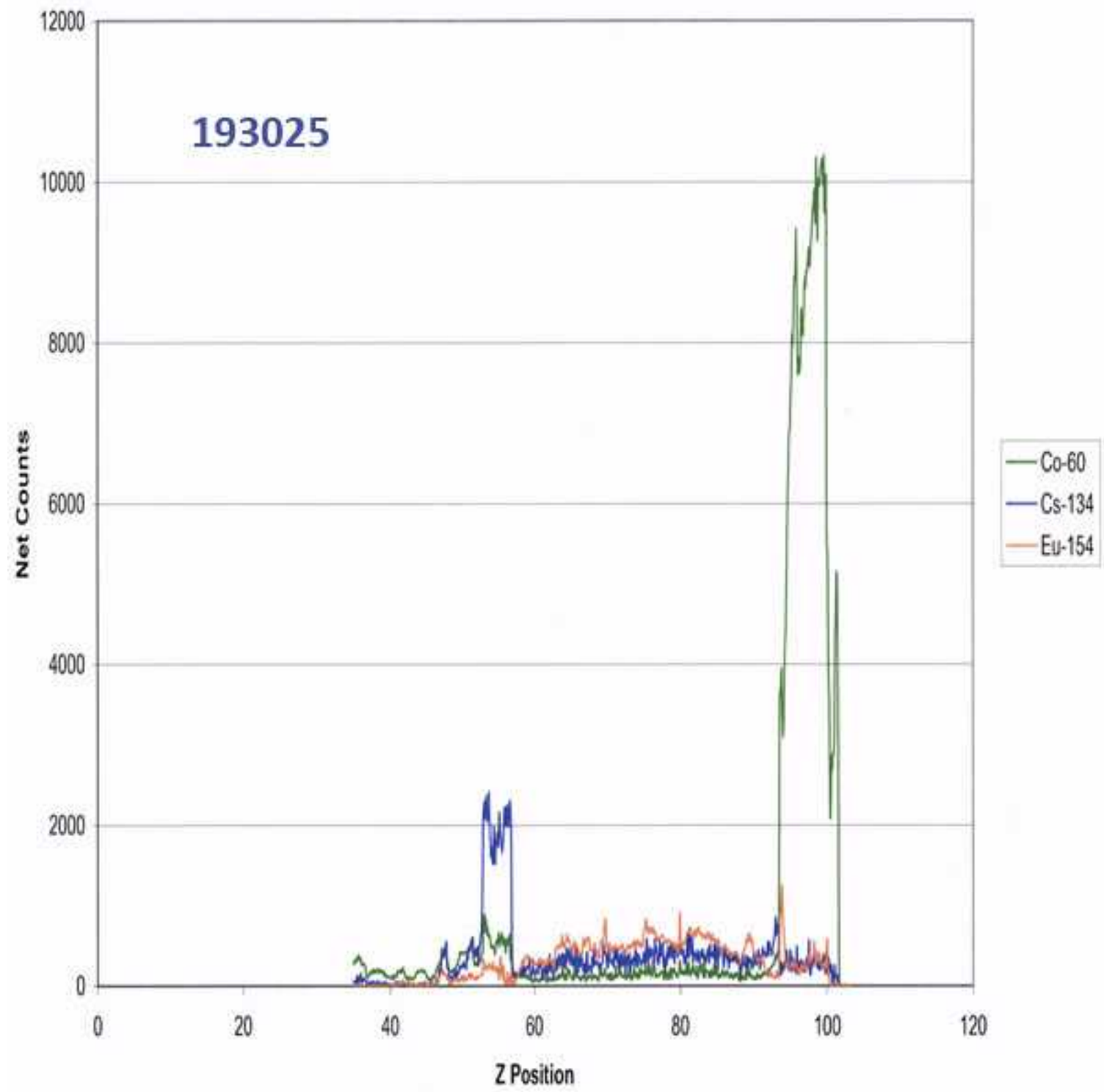

Figure C-2. Gamma scan traces for MFF-3 Pin 193025. Co-60 peaks in Inconel reflector, Cs-134 peaks just above fuel column (lower Z-position is top of pin). 


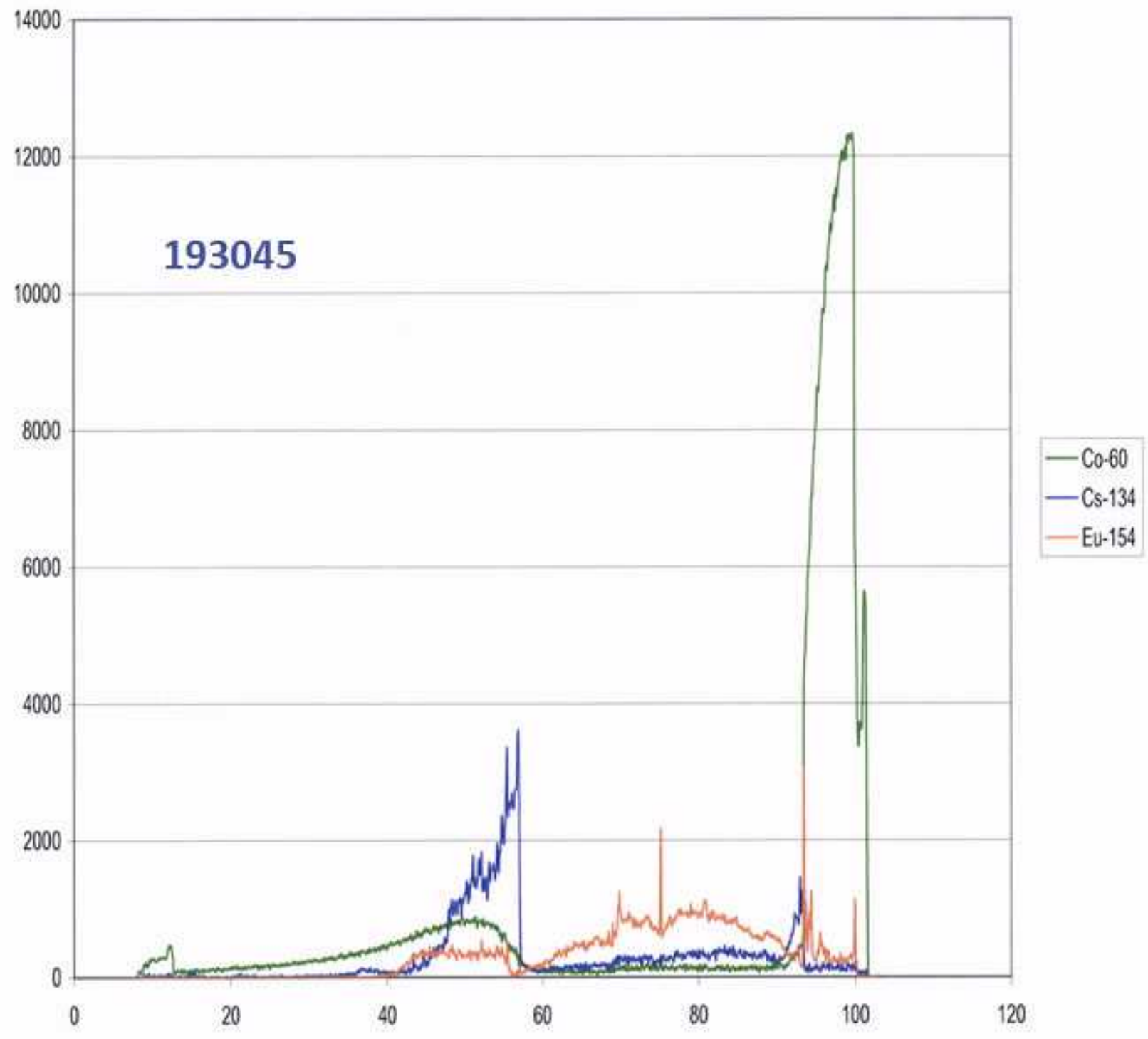

Figure C-3. Gamma scan traces for MFF-3 Pin 193045. Co-60 peaks in Inconel reflector, Cs-134 peaks just above fuel column (lower Z-position is top of pin). 


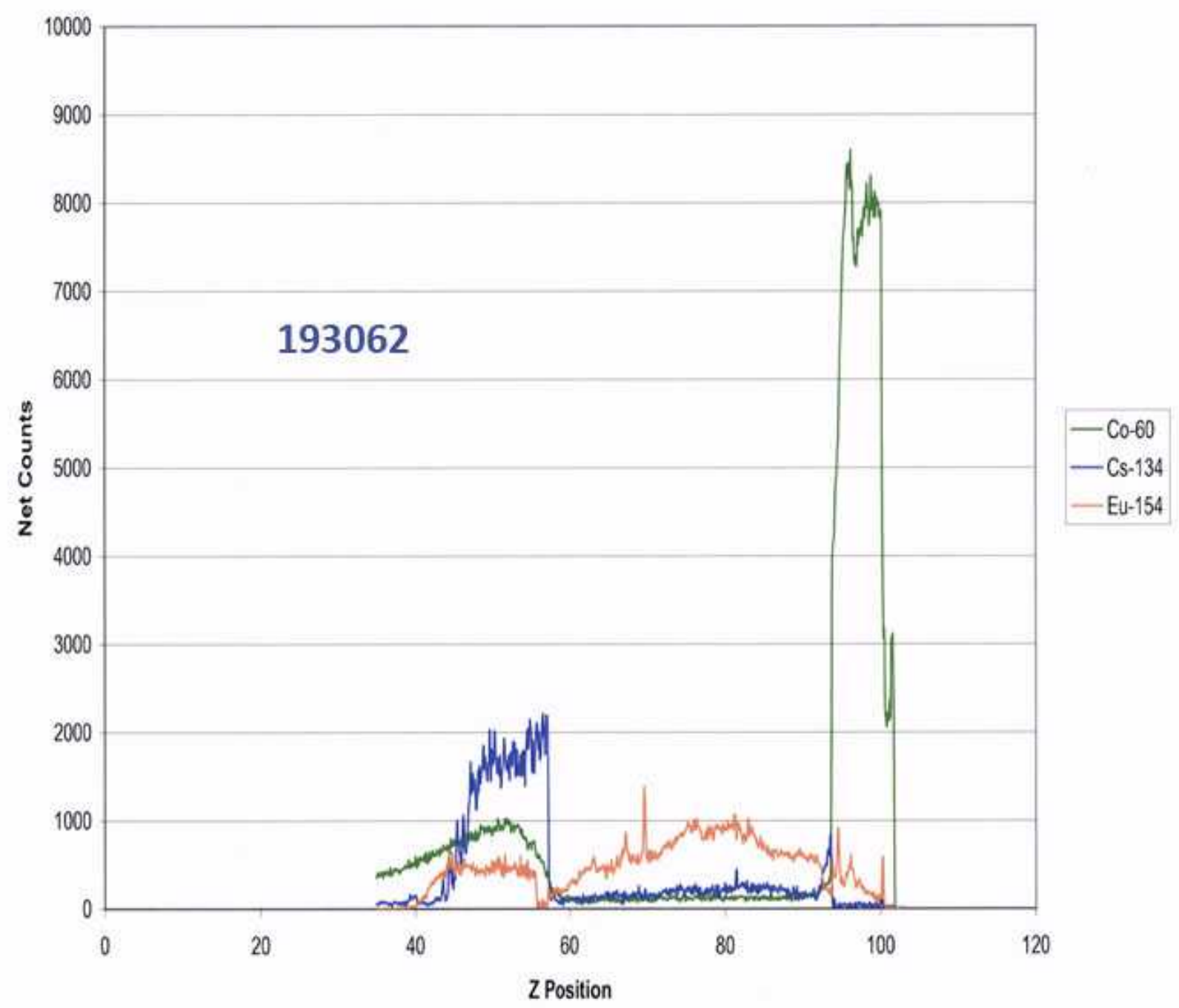

Figure C-4. Gamma scan traces for MFF-3 Pin 193062. Co-60 peaks in Inconel reflector, Cs-134 peaks just above fuel column (lower Z-position is top of pin).

\section{MFF-5 Gamma Scans}

Four MFF-5 pins were scanned for gamma activity and specifically Co-60, Cs-134, and Eu-154 were noted. The scans are shown in Figures C-5 through C-8. 


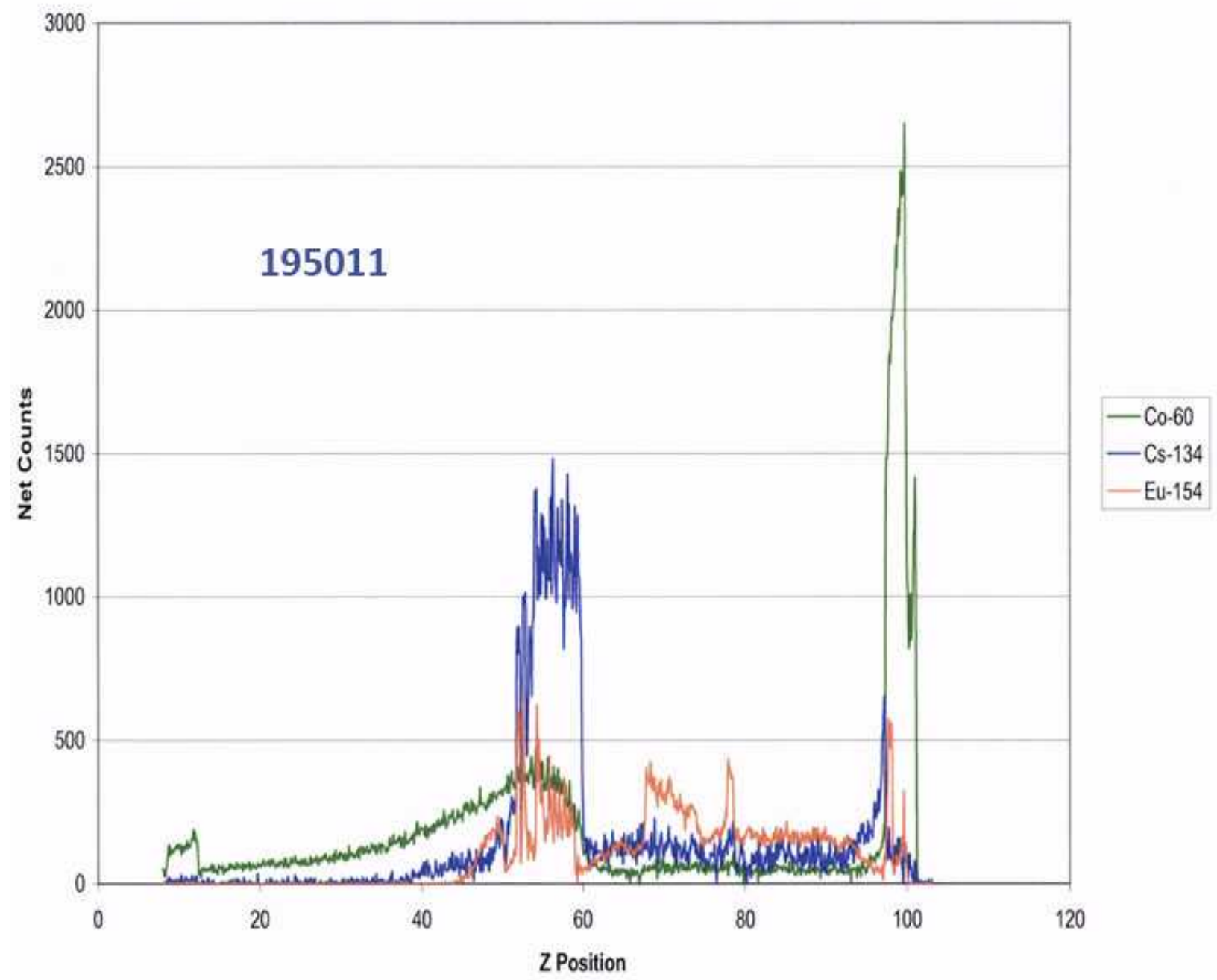

Figure C-5. Gamma scan traces for MFF-5 Pin 195011. Co-60 peaks in Inconel reflector, Cs-134 peaks just above fuel column (lower Z-position is top of pin). 


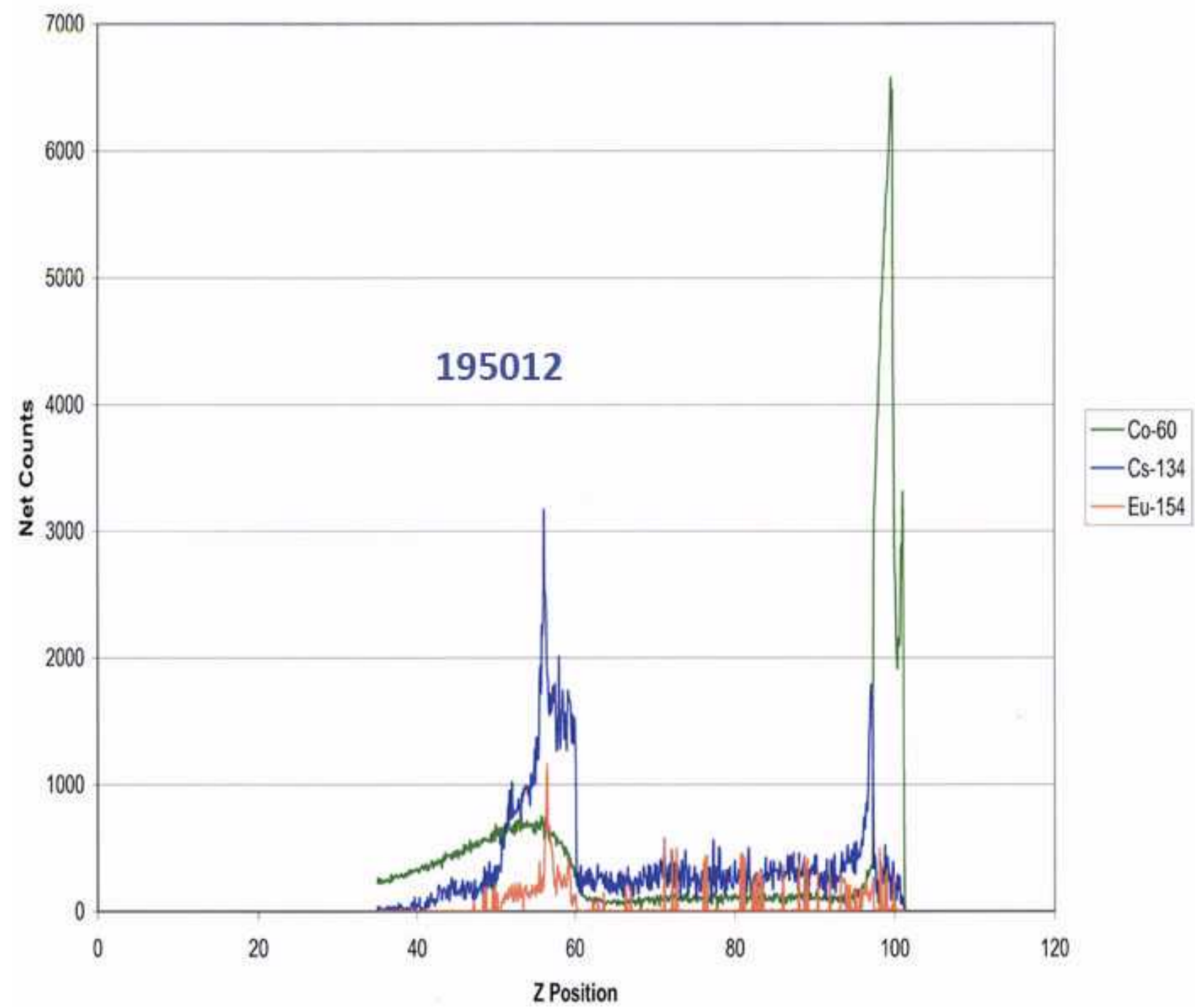

Figure C-6. Gamma scan traces for MFF-5 Pin 195012. Co-60 peaks in Inconel reflector, Cs-134 peaks just above fuel column (lower Z-position is top of pin). 


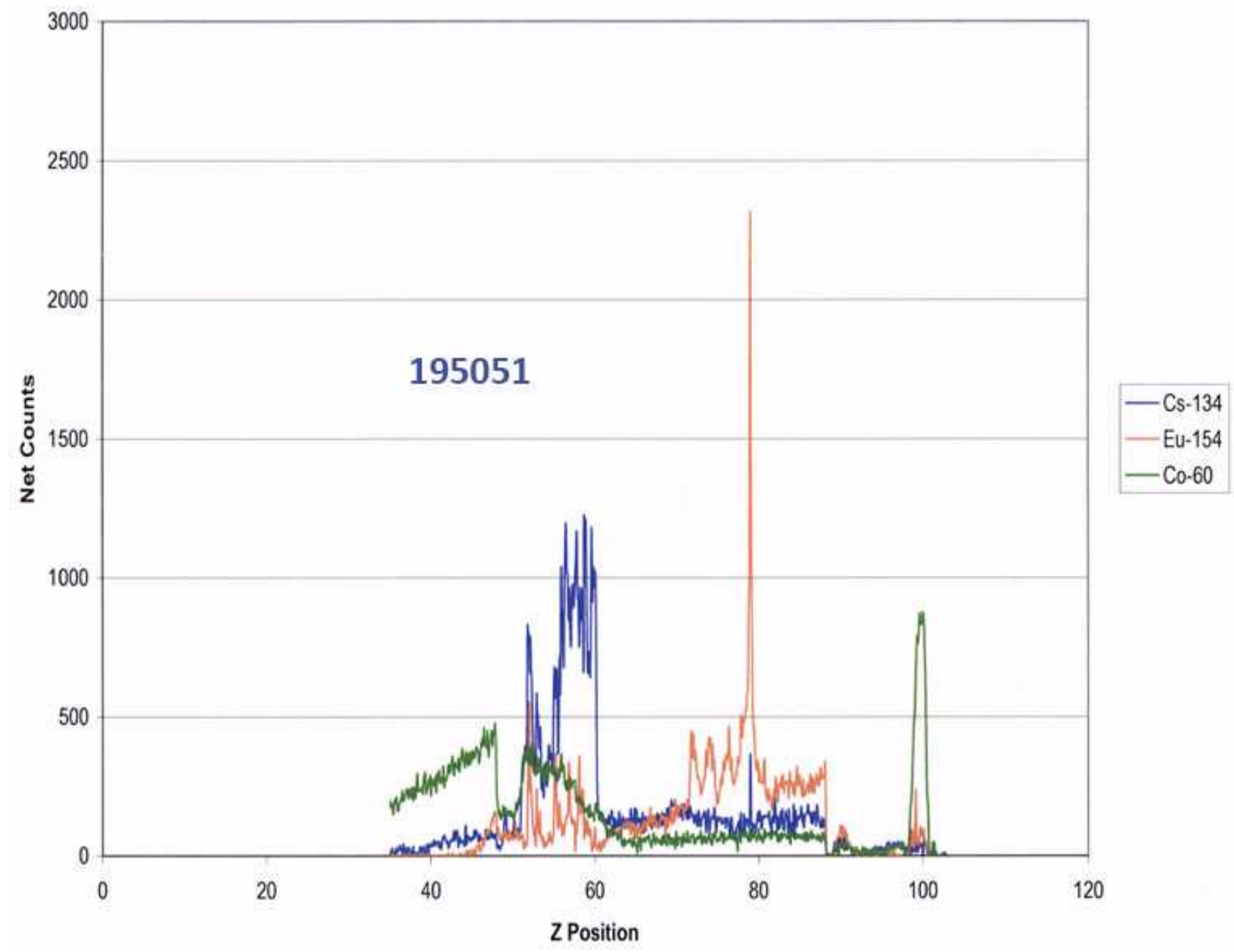

Figure C-7. Gamma scan traces for MFF-5 Pin 195051. Co-60 peaks in Inconel reflector, Cs-134 peaks just above fuel column (lower Z-position is top of pin). 


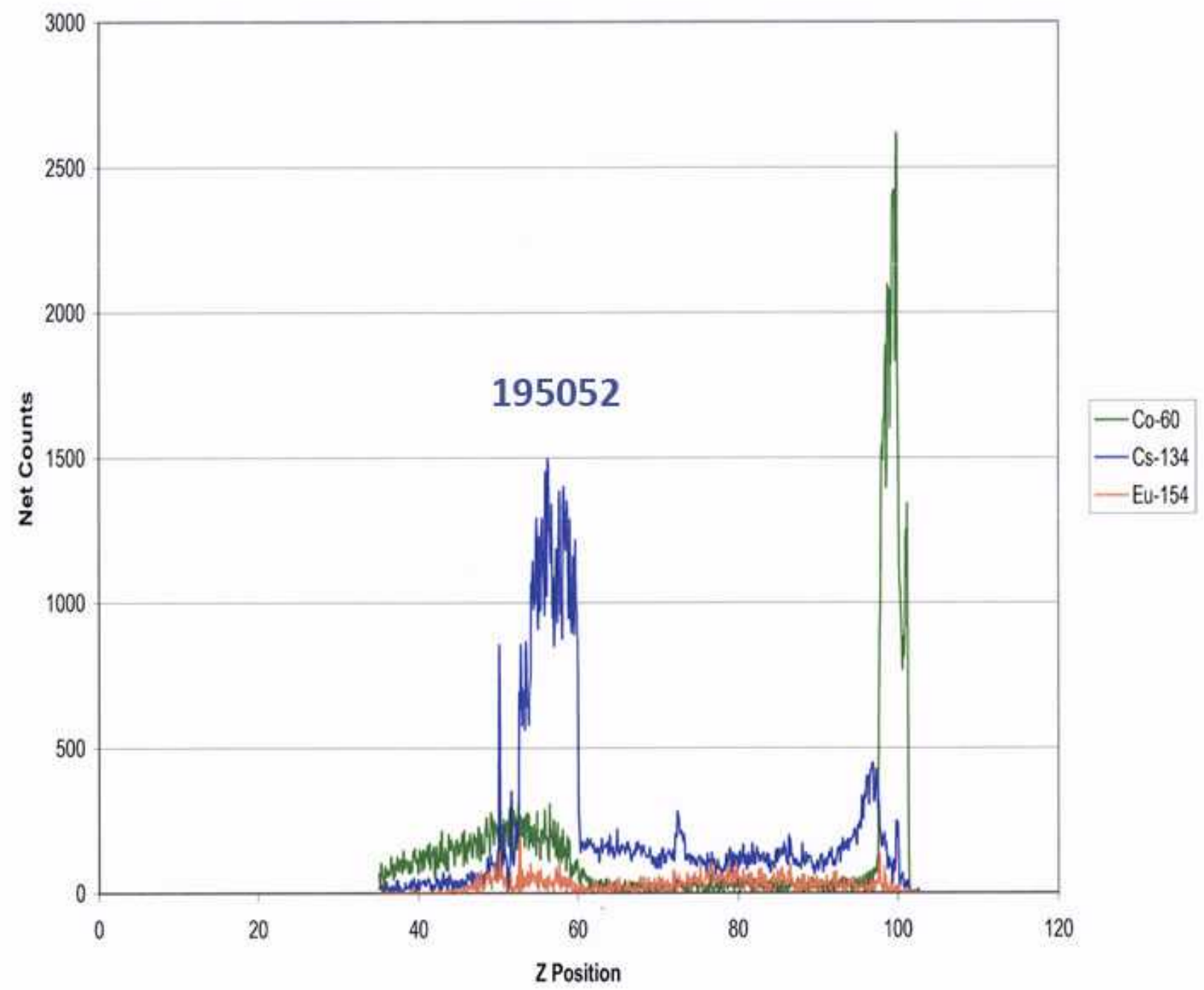

Figure C-8. Gamma scan traces for MFF-5 Pin 195052. Co-60 peaks in Inconel reflector, Cs-134 peaks just above fuel column (lower Z-position is top of pin).

1. Till, C. E. and Y. I. Chang, "PLENTIFUL ENERGY - The Story of the Integral Fast Reactor," ISBN:978-1466384606 (2012).

2. Crawford, D. C., D. L. Porter, and S. L. Hayes, 2007, "Fuels for Sodium-cooled Fast Reactors: U.S. Perspective," Journal of Nuclear Materials, Vol. 371, pp. 202-231.

3. Porter, D. L. and H. Tsai, "Full-length $\mathrm{U}-\mathrm{xPu}-10 \mathrm{Zr}(\mathrm{x}=0,8,19$ wt.\%) Fast Reactor Fuel Test in FFTF," Journal of Nuclear Materials, Vol. 427 (2012), pp. 46-57

4. Pitner, A. L. and R. B. Baker, "Metal Fuel Test Program in FFTF," Journal of Nuclear Materials, Vol. 204 (1993), pp. 124-130.

5. Pahl, R. G., C. E. Lahm and S. L. Hayes, "Performance of HT9 Clad Metallic Fuel at High Temperature," Journal of Nuclear Materials, Vol. 204 (1993) pp. 141-147.

6. Wootan, D. W. and J. V. Nelson, "Irradiation Data for the MFF-3 and MFF-5 Tests in the FFTF," PNNL-20249, March, 2011.

7. Nelson, J. V., 3DBF User's Manual, WHC-SD-FF-SWD-037, Rev. 0, Westinghouse Hanford 
Company, Richland, Washington.

8. Bennett, R. A., et. al., 1994, FFTF Core Management Methods, WHC-SD-FF-CMMD-001, Rev. 0E, Westinghouse Hanford Company, Richland, Washington. [Applied Technology].

9. Cramer, E. R. and A. L. Pitner, Transactions of the American Nuclear Society (San Francisco, California 1989) p. 306.

10. Hayes, S. L., SAFE: a computer code for the steady-state and transient thermal analysis of LMR fuel elements, ANL-IFR-221 (1993).

11. Hofman, G. L., R. G. Pahl, C. E. Lahm, and D. L. Porter, 1990, "Swelling Behavior of U-Pu-Zr Fuel," Metallurgical Transactions A, Vol. 21A, pp. 518-528.

12. Unpublished work.

13. Ethridge, J. L. to B. R. Seidel, personnel communication, "MFF-2 Axial Fuel Growth to Account for Power Decrease," September 12, 1988.

14. Hofman, G. L., S. L. Hayes, and M. C. Petri, "Temperature Gradient Driven Constituent Redistribution in U-Zr Alloys," Journal of Nuclear Materials, Vol. 227 (1996) pp. 277-286.

15. Pahl, R. G., D. L. Porter, C. E. Lahm, and G. L. Hofman, "Experimental Studies of U-Pu-Zr Fast Reactor Fuel Pins in the Experimental Breeder reactor-II," Metallurgical Transactions A, Vol. 21A (1990) pp. 1863-1870.

16. Keiser, D. D., Fuel-Cladding Interaction Layers in Irradiated U-Zr and U-Pu-Zr Fuel Elements, ANL-NT-240 (2006).

17. Carmack, W. J., Temperature and Burnup Correlated FCCI in U-10Zr Metallic Fuel, A Dissertation Presented in Partial Fulfillment of the Requirements for the Degree of Doctor of Philosophy with a Major in Nuclear Engineering in the College of Engineering, University of Idaho (May 2012).

18 Hofman, G. L. and L. C. Walters, Metallic Fast Reactor Fuels from Nuclear Materials, Part I Vol 10 A, Materials Science and Technology, A comprehensive Treatment, B. R. T. Frost, R. W. Cahn, P. Haasen, and E. J. Kramer editors, VCH Verlagsgesellschaft mbH. 